
Beth A. Griech-Polelle (ed.)

\section{The Nuremberg War Crimes Trial and its Policy Consequences Today}

$2^{\text {nd }}$, revised and extended edition

\section{Nomos}


(c) Title page: Image courtesy of the Robert H. Jackson Center from the collection of Raymond D'Addario.

Die Deutsche Nationalbibliothek verzeichnet diese Publikation in der Deutschen Nationalbibliografie; detaillierte bibliografische Daten sind im Internet über http://dnb.d-nb.de abrufbar.

The Deutsche Nationalbibliothek lists this publication in the Deutsche Nationalbibliografie; detailed bibliographic data are available on the Internet at http://dnb.d-nb.de

ISBN

$$
\begin{aligned}
& \text { 978-3-8487-3688-1 (Print) } \\
& \text { 978-3-8452-8040-0 (ePDF) }
\end{aligned}
$$

\section{British Library Cataloguing-in-Publication Data}

A catalogue record for this book is available from the British Library.

ISBN

$$
\begin{aligned}
& \text { 978-3-8487-3688-1 (Print) } \\
& \text { 978-3-8452-8040-0 (ePDF) }
\end{aligned}
$$

\section{Library of Congress Cataloging-in-Publication Data}

Griech-Polelle, Beth A.

The Nuremberg War Crimes Trial and its Policy Consequences Today $2^{\text {nd }}$, revised and extended edition

Beth A. Griech-Polelle (ed.)

274 pp.

Includes bibliographic references and index.

ISBN

$$
\begin{aligned}
& \text { 978-3-8487-3688-1 (Print) } \\
& \text { 978-3-8452-8040-0 (ePDF) }
\end{aligned}
$$

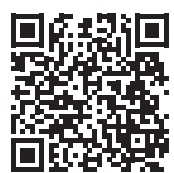

Onlineversion Nomos elibrary

$2^{\text {nd }}$, revised and extended edition, 2020

(c) Nomos Verlagsgesellschaft, Baden-Baden 2020. Gedruckt in Deutschland. Alle Rechte, auch die des Nachdrucks von Auszügen, der fotomechanischen Wiedergabe und der Übersetzung, vorbehalten. Gedruckt auf alterungsbeständigem Papier.

This work is subject to copyright. All rights reserved. No part of this publication may be reproduced or transmitted in any form or by any means, electronic or mechanical, including photocopying, recording, or any information storage or retrieval system, without prior permission in writing from the publishers. Under $§ 54$ of the German Copyright Law where copies are made for other than private use a fee is payable to "Verwertungsgesellschaft Wort", Munich.

No responsibility for loss caused to any individual or organization acting on or refraining from action as a result of the material in this publication can be accepted by Nomos or the editor. 


\section{Preface: The Spirit of Nuremberg-Idealism}

Henry T. King, Jr.

Harold Nickelson, a British journalist, came to Nuremberg to have a look at the proceedings before the International Military Tribunal. Later he wrote: "[I]n the courtroom at Nuremberg something more important was happening than the trial of a few captured prisoners. The inhuman was being confronted with the humane, ruthlessness with equity, lawlessness with patient justice, and barbarism with civilization." In a few words Nickelson captured the idealism that gave Nuremberg its forward thrust. Under the leadership of Robert Jackson we had the vision of a better world, and we moved through Nuremberg to achieve it.

It wasn't easy, because there were those, including Winston Churchill and Joseph Stalin, who wanted to avoid a trial and expedite matters through summary executions. Such a procedure would not have been a benchmark for a better world. Summary execution would have meant that the world stood still morally and that its leaders had not tried to build a better future for all of mankind. But a public trial held significant risks. Germany had surrendered unconditionally, but there was a fear that the defendants could use the trials to incite violence against the victorious powers.

There was also a big element of personal risk for those such as myself who participated in Nuremberg. I gave up a secure legal position on Wall Street to participate in an undertaking whose outcome and impact on the future were unknown. The American public did not seem ready for Nuremberg. Isolationists and those just tired of the war saw it as prolonging U.S. involvement. There were, in fact, many who attempted to dissuade me from going to Nuremberg because "You will lose your place in life on the avenue of success." The question each of us had to ask was: 'Are those risks greater than the need to stand up against Nazi atrocities and the possibility that they would be repeated?" Our answer was, and still is, No!

Let's take a look at how Nuremberg became a reality. As World War II was drawing to a close, the Allied leaders needed to settle the question of what to do with the former leaders of Nazi Germany, most of whom were in the custody of the United States. As I indicated previously, two important people favored summary execution but-on the advice of his Secre- 
tary of War, Henry L. Stimson-President Franklin Roosevelt leaned strongly toward a trial until his unanticipated death on April 12, 1945. The very next day, April 13, 1945, Justice Robert H. Jackson of the United States Supreme Court gave a speech before the annual meeting of the American Society of International Law in which he advocated a trial-a fair trial. In his address Jackson indicated that he wanted no part of a "show" trial designed only to convict. Convictions, he said, should be based solely on fully supported evidence. If the evidence was not there to support a conviction, the individual should be acquitted.

Jackson's observations on a prospective trial of Nazi war criminals were acknowledged by the White House on May 2, 1945, when President Truman appointed him as his plenipotentiary in planning with the Allies for the trial. On June 6, 1945, Jackson reported back to the President, outlining his plans for the substantive aspects of the trial, including the charges he felt should be the basis for it. The first crime was aggressive war, which was styled as crimes against peace. Jackson felt that this was a fundamental crime and consisted of planning, preparation, and waging wars of aggression and wars in violation of international treaties. The second charge recommended by Jackson was war crimes, that is, crimes against civilians and prisoners of war in violation of the laws of war. This was based on the Hague and the Geneva Conventions governing conduct of warfare, which most nations of the world adhered to.

The third charge was crimes against humanity, which dealt with multiple types of assault on civilians, particularly including murder and persecution of individuals on grounds of race, religion, or national origin. This was indeed a sweeping charge designed to cover all assaults on civilians not considered war crimes. Hitler was once asked by his generals what the world would think if they killed every man, woman and child in Poland. His response was, "Who remembers the Armenians?" referring to the Turkish army's genocide of 1.5 million Armenians beginning in 1915. The crimes against humanity charge gave notice that the world would no longer turn a blind eye to crimes against civilians just because they were committed by a sovereign state.

Jackson also advocated a conspiracy charge to cover those who conspired to commit the foregoing crimes, recognizing that these atrocities did not happen in a vacuum. Those most responsible often did not get their own hands dirty, but that should not prevent their being held accountable. By stressing the treaties and customary international law the Nazis violated, he preempted the defense that Nuremberg was applying ex post facto laws. This accomplished two things. It helped codify existing international law, laying the groundwork for modern prosecutions in ad hoc 
tribunals and the International Criminal Court (ICC). But more important to those of us at Nuremberg, it reinforced Jackson's vision of a fair trial, not victor's justice.

In his report to President Truman, Jackson also advocated the elimination of two prospective defenses by the Nazi war criminals, namely sovereign immunity and superior orders. He felt that if these two defenses were allowed in combination, then no one could be convicted because no one could be held responsible. Regarding the sovereign immunity defense, Jackson thought there should be the fullest responsibility where authority was highest. No longer, he felt, should those who exercise authority in the name of the nation escape responsibility for their deeds; he recommended that they be called to full account. Regarding the superior orders defense, he felt that the Nazi leaders who would be subject to trial should not be able to hide behind the defense that they were just obeying their superiors; he felt that those who committed criminal acts should be called to account and punished for their actions. Jackson exercised great foresight in eliminating this defense, because in Nazi Germany, an absolute dictatorship, most important orders were issued in Hitler's name, and Hitler was nowhere to be found, having, as we later determined, committed suicide in his Berlin bunker on April 30, 1945.

The Allies met in London in the early summer of 1945 to discuss Jackson's draft of a proposed procedure for the trials. Neither the British nor the French requested substantive changes, although the French disliked the conspiracy charge because they felt that conspiracy, to the extent it existed, merged with the substantive crime itself. With the USSR it was a different story. Their representatives argued that the aggressive war count should apply only to the Nazis' actions, because they felt that the generic approach could be extended to cover some of their own activities. For the most part Jackson held the line on this one. The compromise reached in the London Agreement and Nuremberg Charter called only for the prosecution of the Axis powers' war criminals, but the definitions were stated in generic terms so as to be universally applicable in the future.

Another issue debated in London was the presumption of guilt or innocence. The Soviet representatives wanted a presumption of guilt with regard to the defendants, while Jackson wanted a presumption of innocence, which would put the burden on the prosecutor to prove the defendants' guilt and give each defendant the benefit of the doubt, elements that are now widely considered essential for a fair trial. Here again Jackson prevailed, and his foresight on this issue gave much increased credibility to the results of the trials. 
The next issue faced was the location of the trial. The USSR representatives wanted it to be held in Berlin. Justice Jackson argued for Nuremberg, which had the largest undamaged courthouse in Germany. Moreover, Nuremberg was of great symbolic significance, because it was the situs of the Nazi party headquarters and of the huge Nazi party rallies where Hitler had proclaimed his challenges to the world. Nuremberg symbolized Nazism at its zenith, and it was important to correct the record as to the true implications of Nazism, which were, indeed, criminal.

The next issue was the selection of the prospective defendants, most of whom were in U.S. custody. Jackson felt that precedence should be given to the leaders of each walk of German life, military or diplomatic, police or industrialist. Here he again prevailed, and it was he, working with the other Allies, who targeted the individuals to be tried at Nuremberg: Joachim von Ribbentrop, the Nazi Minister of Foreign Affairs-found guilty on all four counts; Reichsmarschall Herman Göring, Commander of the Luftwaffe-guilty on all four counts; Gustav Krupp von Bohlen und Halbach, chairman of the Association of German Industrialists and a major arms manufacturer who used slave labor from occupied countries and concentration camps-indicted on all four counts; Julius Streicher, a publisher who used his newspaper and children's books to incite antiSemitism-convicted of crimes against humanity.

Jackson also thought that the defendants should be well-represented, and he arranged for the Allied Control Commission to assume the costs of defense counsels and also for such counsel to be largely of the defendants' own choosing. With regard to presenting the case against the defendants at Nuremberg, Jackson felt that, as far as the U.S. prosecution was concerned, the evidence against the Nazis would basically convict themselves and the result would have greater long-term credibility. The outcome of all these negotiations was the London Charter of August 8, 1945, which provided the basis for the trials.

Nuremberg officials began on November 20, 1945, but the real opening was on November 21, when Justice Jackson delivered the opening statement for the United States of America, setting forth what Nuremberg was all about. Some high points are worthy of particular note:

First, Jackson stated: "The complaining party at the bar here today is civilization." By this he meant that the trial was to make a break with the barbarism of the past-barbarism on so great a scale that it had cost 50 million lives in World War II and reached new limits of degradation never before experienced in history.

Second, Jackson called the trial "one of the most significant tributes ever paid by power to reason." He meant that reason was now to be the order 
of the day, and that the guilt of the defendants would be determined through the use of reason in a fair trial. Summary execution of the defendants by the Allied powers based on their military dominance was not to be permitted. The force of law was, indeed, to replace the law of force.

Third, Jackson said, "As we pass a poison chalice to the lips of these defendants, we pass it to our lips as well," meaning that the trial was to represent equity and that the Allies themselves who brought the charges against the Nazi defendants were to be governed in their future behavior by the standards established at Nuremberg. He felt that if Nuremberg was to have lasting meaning, the principles established there should comprise benchmarks for the behavior of all peoples of the world then and in the futurethat, indeed, they should have universal application in the interests of fairness and equity.

In sum, what Jackson wished to convey through his opening statement was that Nuremberg was to mark the beginning of a new era in human history, and indeed, he was the architect of Nuremberg and this was his vision, which is as valid today as it was 60 years ago.

Jackson's foresight in focusing on documents from the Nazis' own files as proof of their guilt bore fruit in the judgment of the International Military Tribunal, which said in effect that the Nazis had convicted themselves with the evidence submitted. The judgment was equitable in that three defendants were acquitted because the evidence was not there to support their convictions. The fears people had before the trials had not been realized. Granting the defendants a fair trial and the right to publicly defend their actions had not resulted in destabilizing the Allies' occupation and rebuilding-efforts. Hermann Göring is widely seen as having gotten the better of Jackson during the cross-examination, and yet he was still convicted-condemned not by clever words, but by the weight of the evidence.

I came home from Nuremberg filled with the spirit of Nuremberg, but the public was not enthusiastic and the bar refused to recognize Nuremberg for what it was-a complete break with the past. Despite having done well at Yale Law School, which then as now ranks among the best, I had trouble getting a job when I returned, partly because of Senator Robert Taft of Ohio and others of his ilk who excoriated Nuremberg. In addition, the Cold War had intervened, and the U.S. and the USSR were engaged in deep conflict on the issues of the day.

With the ending of the Cold War in the late 1980s, Nuremberg has to a considerable extent achieved the recognition it has always deserved. The Nuremberg principles are being followed in UN-sponsored and other tribunals, and an international court has been formed and charged with the enforcement of what was substantively established at Nuremberg. In a 
number of areas of the world a new regime of international human rights is the order of the day.

Much progress has been made, but today the United States, which through Jackson created Nuremberg, is fighting a rearguard action against the advances of the Nuremberg principles, which Jackson believed should be applied in judging the conduct of all nations and leaders. The U.S. has turned its back on the International Criminal Court, which would institutionalize Nuremberg, and, by holding prisoners without trial and subjecting them to torture, has disregarded the Geneva Conventions of 1949 governing the treatment of prisoners taken in the course of hostilities. Progress is using our resources to create a better, more just world, not manipulating language and digging for loopholes to lower the minimum standards of decency.

The fears the world faces today are not new. Even courageous people such as Winston Churchill feared that providing Nazi leaders a fair and public trial would undermine the fragile security brought about by the $\mathrm{Al}-$ lied victory. Nuremberg faced those fears and proved that the rule of law is not such a fragile thing, that it strengthens democracies even when applied to those who would deny it to others. What is needed now is a revival of the spirit of Nuremberg. A better and more peaceful world based on justice is within our grasp; with the major powers at peace and no longer on the brink of war, we have a golden opportunity to build a more secure future for generations to come. This was in effect our goal at Nuremberg, and at considerable self-sacrifice. I hope that there are those among the current generation who will take it upon themselves to follow in our footsteps.

So-let idealism and vision be the order of the day. Let us use conferences such as this as a means to rekindle the enthusiasm which brought about Nuremberg. We can, indeed, achieve a better world if we are willing. 


\section{Table of Contents}

Introduction: The Legacy of Nuremberg

Beth A. Griech-Polelle

\section{Section I: The Immediate Postwar Trials and Their Short-Term Effects}

On the Way to Nuremberg: The Soviets Commission for the Investigation of Nazi War Crimes

Marina Yu. Sorokina

German Participation in the Nuremberg Trials and Its Implications for Today

Christoph J. M. Safferling

The Appropriation by German Courts in French-occupied Baden of Control Council Law No. 10's Definition of Crimes against

Humanity in the Prosecution of Nazi-era Defendants, 1946-1951

Michael S. Bryant

"Violation of Human Dignity" and Other Crimes Against Humanity in Austrian War Crimes Trials

Winfried R. Garscha

Brother, Black Sheep, or Bastard? Situating the Tokyo War Crimes Trial in the Nuremberg Legacy, 1946-1948

James Burnham Sedgwick

The Nuremberg Trials and American Jurisprudence: The Decline of Legal Realism, the Revival of Natural Law, and the Development of Legal Process Theory

Rodger D. Citron 
Section II: The Present-Day Impact of Nuremberg on International Law

The International Criminal Court and the Ethics of Selective Justice Aaron Fichtelberg

The United Nations War Crimes Commission: A Model for Complementarity today?

Dan Plesch and Leah Owen

In Search of Imperfect Justice: Genocidal Rape and the Legacy of Nuremberg and Tokyo

Tazreena Sajjad

The Documentary Record of Nuremberg in the Twenty-First Century

Judith Haran

United States Military Law of War Doctrine: Making the International Criminal Court Irrelevant to the Ground Combat Forces of the United States in the Early Twenty-First Century

Rex A. Childers

Subject Index

Index of Persons 


\title{
Introduction: The Legacy of Nuremberg
}

\author{
Beth A. Griech-Polelle
}

On October 6-7, 2006, the Graduate Program in Policy History of Bowling Green State University in Bowling Green, Ohio, welcomed social scientists and legal experts to a conference entitled, "The Nuremberg Trial and Its Policy Consequences Today." ${ }^{1}$ The conference, marking the sixtieth anniversary of the International Military Tribunal proceedings, featured leading authorities on the Nuremberg Trials, as well as sessions which engaged in examining the historical meaning of Nuremberg and its implications for today's world. Without the dedication and limitless energy of Professor Don K. Rowney, the international conference might never have come to fruition. The volume's second edition presented here continues to reflect the scholarly commitment to confronting the meaning of justice, just as the original edition did.

By the close of the Second World War, the most destructive conflict in human history, there was a pervasive feeling that Nazi Germany's wartime behavior was so unprecedented and so horrifying that the war could not conclude without some form of criminal punishment. News of the atrocities had already reached media outlets across the world beginning in 1942, and by the time Allied troops reached Berlin, it had been decided that an international trial composed of the four major Allied powers (the United States, Great Britain, France, and the Soviet Union) would take place in the southern German city of Nuremberg. The location was both practical and symbolic: symbolically, the Nazi regime had met annually at Nuremberg to showcase the "best" of National Socialsim; practically, Nuremberg was one of the few cities to retain its courthouse after so much aerial bombardment. So Nuremberg, it was determined, would be the location for a trial of "major war criminals."

How were alleged war criminals to be brought to justice? For many of the Allied leaders this was a perplexing question. Many leaders referenced

1 The title of this volume, The Nuremberg War Crimes Trial and Its Policy Consequences Today, was adopted because, though perhaps technically not altogether correct, it seems to reflect more accurately the general public's consciousness that more than one person was tried at Nuremberg. 
the treatment of Napoleon Bonaparte after his defeat at the Battle of Waterloo in 1815, while still others reflected on the attempt to hold war crimes trials following World War I. What certainly helped Allied leaders in a post-World War II world was an agreement signed in 1928, the Kellogg-Briand Pact (also called the Briand-Kellogg Pact), in which recourse to war was condemned and, in essence, made illegal. This pact was signed by fifteen countries, including Germany, and formed at least a part of the basis for the trials at Nuremberg. In the words of Henry L. Stimson, U.S. Secretary of War, "War between nations was renounced by the signatories of the Briand-Kellogg Pact. This means that it has become illegal throughout practically the entire world." ${ }^{2}$ However, saying that there should be a tribunal and actually establishing one that worked would prove to be two different things for the victorious Allied Powers.

Various plans and competing visions were proposed as to how a tribunal should proceed, and all types of conflicts emerged regarding how the Allies would work together. It was ultimately the impact of the new President of the United States, Harry S. Truman, that swung the pendulum in favor of the American policy of establishing an international military tribunal (as opposed to a civilian one) composed of one representative of each of the four powers. Each power was immediately to begin collecting evidence which would then be presented to the IMT. It was also proposed that Nazi organizations be placed on trial rather than individuals, so that anyone who had willingly joined the organization would be guilty of a war crime if the organization was proven guilty. As the Americans forcefully pursued this vision of a tribunal, their determination eventually convinced the British, the French, and the Soviets to accept their plan.

Once the four powers had worked through a series of negotiations on the general plan for prosecution, a formal indictment was signed on October 6, 1945. Setting the pace for all of the Allied team was the Chief Prosecutor for the United States, Robert H. Jackson. However, Jackson immediately encountered a very different attitude on the part of the Soviet jurists. To them the Nazi leaders were already guilty, and the tribunal's chief task would be to determine each individual person's level of guilt and what their punishment should be, whereas to Jackson and to the other Western delegations, the trial's outcome was not going to be a foregone conclusionthat is, actual cases had to be built and proven to establish guilt. Once the many hurdles were overcome, the Allied Powers signed an agreement for a

2 Henry L. Stimson, “The Pact of Paris: Three Years of Development," Foreign Affairs 11 (1932), Special Supplement, iv. 
trial. Attached to the agreement was a charter which was to function as the governing tool of the International Military Tribunal, and included in this charter was Article 6, which laid out crimes against peace, war crimes, and crimes against humanity as crimes falling within the jurisdiction of the IMT and for which there would be individual responsibility.

For most of us, the photographs from Nuremberg reveal a courtroom, overwhelmingly grave, overcrowded with judges, defendants, lawyers, translators, reporters, and American guards all set about with headsets, wires, and all types of translating equipment, but it is the remembrances of Henry T. King, a member of Justice Jackson's team, that captures the electricity of the moment. In his preface here, King recalls the current of idealism that pulsated through the proceedings, largely due to Justice Jackson's belief that this tribunal represented a break with the past. Jackson, like so many others present, thought that they would be setting new benchmarks for all people's behavior by replacing the law of force with the force of law. In Jackson's opening statement of November 21, 1945, he made clear the difficulty in meting out justice in such a situation:

Unfortunately, the nature of these crimes is such that both prosecution and judgment must be by victor nations over vanquished foes. The worldwide scope of the aggressions carried out by these men has left but few real neutrals. Either the victors must judge the vanquished or we must leave the defeated to judge themselves. After the first World War, we learned the futility of the latter course. The former high station of these defendants, the notoriety of their acts, and the adaptability of their conduct to provoke retaliation make it hard to distinguish between the demand for a just and measured retribution, and the unthinking cry for vengeance which arises from the anguish of war. It is our task, so far as humanely possible, to draw the line between the two. We must never forget that the record on which we judge these defendants today is the record on which history will judge us tomorrow. To pass these defendants a poisoned chalice is to put it to our own lips as well. We must summon such detachment and intellectual integrity to our task that this Trial will commend itself to posterity as fulfilling humanity's aspiration to do justice. ${ }^{3}$

3 International Military Tribunal, Trial of the Major War Criminals before the International Military Tribunal, 14 November 1945 - 1 October 1946, 42 vols. (Nuremberg: International Military Tribunal, 1947), 2:104-105. 
This volume explores both the immediate, short-term effects of the IMT at Nuremberg and the present-day impact that the trials have had on the field of international law. It seeks to examine how the legacy of the Nuremberg Trials has been implemented in subsequent trials and how it has impacted international tribunals today. The spirit which permeates this volume is similar to that at Nuremberg as expressed by Henry T. King, the notion that a "better and more peaceful world based on justice is within our grasp." 4 Accompanying this desire for a just world is the idea that we as scholars must debate, discuss, and work to establish some rule of law in a dangerous and violent world. In January 1947 Henry L. Stimson, from the State Department, remarked on the legacy of the Nuremberg Trials:

International law is still limited by international politics, and we must not pretend that either can live and grow without the other. But in the judgment of Nuremberg there is affirmed the central principle of peacethat the man who makes or plans to make aggressive war is a criminal. A standard has been raised to which Americans, at least, must repair; for it is only as this standard is accepted, supported, and enforced that we can move onward to a world of law and peace. ${ }^{5}$

Section I opens with Marina Sorokina's explication of how evidence was collected by Soviet academicians and researchers long before the war had come to an end and how their research was used by the prosecution team at Nuremberg. Her examination of newly available Soviet archival material reveals the myth-making machinery of the Stalinist regime and threatens to challenge the "accepted" history of the Soviet Extraordinary Commission for the Investigation of Nazi War Crimes. Sorokina's essay is followed by Christoph Safferling's examination of the German public's attitude before and during the historical Nuremberg Trials, the role that German defense attorneys played there, and the many reservations and obstacles that had to be overcome by the legal experts.

Moving forward in time, Michael S. Bryant's essay addresses the issue of how Germans were placed in control of prosecuting Nazi war crimes in French-occupied Baden from 1946 to 1951. Once the Nazi government was defeated, the Allies temporarily closed all ordinary German courts and then reopened them with limited jurisdiction. Allied Control Council Law No. 10 allowed these courts to exercise jurisdiction over crimes against hu-

4 See Henry T. King, Jr., "Preface: The Spirit of Nuremberg-Idealism”, The Nuremberg War Crimes Trial and Its Policy Consequences Today (Baden-Baden: Nomos, 2009), 11.

5 Henry L. Stimson, “Nuremberg: Landmark in Law,” Foreign Affairs 25 (1947), 189. 
manity when both the perpetrators and the victims were German nationals or "stateless persons." Bryant observes that German prosecutors enjoyed distinct advantages in trying National Socialist crimes under Control Council Law No. 10 that were denied them under conventional German criminal law.

Winfried Garscha's research examines how in the postwar world Austrians came to define crimes against humanity as violations of human dignity, making such a charge a punishable offense under Austrian law. In this case the War Criminals Act redefined violations of human dignity, as well as assault and battery, as severe crimes which could be punished under certain circumstances if they had been committed in the interests of the Nazi regime. Garscha explores the intent and the judicial reality of the new Austrian laws in comparison with the prosecution of Nazi atrocities by Allied and German courts.

James Burnham Sedgwick's article provides yet another contrast with Allied and German courts through his examination of the International Military Tribunal for the Far East 1946-1948, more commonly known as the Tokyo Trial. Sedgwick argues that, taken together, Tokyo and Nuremberg attempted to establish a legal framework to end future wars, but fitting the Tokyo proceedings into the Nuremberg legacy is filled with incongruities: "Japan was not Germany; Tojo was no Hitler." 6 The limitations exposed by the Tokyo Trial underscore the need for flexibility and justice, and by examining the flaws that emerged out of Tokyo, future international tribunals can hopefully avoid these mistakes.

The final essay of Section I, by Roger Citron, examines the influence of the Nuremberg Trials on American legal thought, specifically on the decline of legal realism, the revival of natural law, and the development of legal process thought. Citron's work discusses how all of these jurisprudential developments were related to and reflected the debate over the question of the legitimacy of the Nuremberg Trials.

Section II of the volume includes several essays addressing problems that have emerged since the Nuremberg Trials and the establishment of the International Criminal Court. Aaron Fichtelberg's work delves into the objection of "selective justice," which has been a common complaint since the Nuremberg Trials, the idea being that only a few people are punished while others are left either unmolested or are prosecuted in lesser

6 See James Burnham Sedgwick, "Brother, Black Sheep, or Bastard? Situating the Tokyo War Crimes Trial in the Nuremberg Legacy 1946-1948," The Nuremberg War Crimes Trial and Its Policy Consequences Today (Baden-Baden: Nomos, 2009), 63. 
courts and receive a lesser punishment. This objection emerged at Nuremberg and resurfaced again in the former Yugoslavia and Rwanda. Fichtelberg argues that a limited form of selective justice based on ethical principles of distributive justice in the international tribunal context is an unavoidable aspect of modern international criminal justice.

Dan Plesch and Leah Owen explore the other major institution of wartime and postwar international criminal justice, the United Nations War Crimes Commission (UNWCC). Plesch and Owen demonstrate how the UNWCC developed alongside that of both the Nuremberg Trials and the Tokyo Trial. The UNWCC indeed provided many of the documents and dossiers used in the Nuremberg Trials. The UNWCC, instead of trying all cases reported to it, aimed to strengthen the existing legal systems in member states. Plesch and Owen argue that the example set by the UNWCC as innovative in its approach to the implementation of positive complementarity could serve as a model for the international criminal justice system of today.

Tazreena Sajjad's article examines the impact of both the Nuremberg and Tokyo Trial's roles in strengthening the regulations against wartime rape and sexual violence. In particular, Sajjad pays special attention to the development of legal jurisprudence of such crimes as instruments of genocide. The essay analyzes the legacy of the trials in laying the groundwork for the ad hoc tribunals of the 1990s and the creation of the International Criminal Court. The article reveals the lack of gender consciousness at both Nuremberg and Tokyo, which resulted in a failure to prosecute rape and sexual violence as war crimes and crimes against humanity. This lack of awareness, Sajjad asserts, continues to play a role in obstructing these crimes in the ICC as acts of genocide.

Judith Haran's essay, as the $75^{\text {th }}$ anniversary of the beginning of the Nuremberg Trials approaches (in 2020), delves into the current status of the evidence collected to document the crimes of Nazi Germany. Most scholars are well aware of the sixty-seven volumes published by the U.S. government at the end of the trial, however, these volumes contain only a small fraction of the trial records. Haran explains the origins of the collection of the documentation, the attempt to find a place for 100 tons of research documentation in the postwar world, and how very little has actually been written about the documents themselves (not their content). Apart from the National Archives in the United States, only Harvard Law School is known to have the nearly complete set of trial records and Harvard has been working on making these documents easily available through the creation of a database and there is still a possibility that other repositories 
could be linked to the Harvard Law School sight, making future research easier for scholars.

Section II concludes with an essay by Rex A. Childers which brings the current ICC standards of combat to the grim reality of U.S. soldiers on the ground trying to abide by international regulations. Using existing U.S. military training and leadership manuals, theater Standard Operating Procedures ( $\mathrm{SOP}$ ), and Rules of Engagement (ROE) guidelines, and following the Judge Advocate General's Operational Law Handbook, Childers examines current practices of the military with regard to internationally identified criminal acts and the ICC's inherent ability to affect the U.S. ground soldier under current U.S military law practices.

It is with great pleasure that I have the opportunity to thank the many people and programs that made this revised edition possible. First and foremost, my thanks go back to the original conference hosted by Bowling Green State University in Bowling Green, Ohio. Professor Don K. Rowney, who conceived the idea and chaired the program committee, was unstinting in his commitment to seeing this project come to fruition. Countless other faculty and graduate students, including the conference executive administrator, Christi Bartman, all poured their enthusiasm into making the conference a success.

I would also like to thank Beate Bernstein and Friederike Wursthorn, of Nomos Verlagsgesellschaft, for their continued support and interest in bringing this revised edition to print. 
Section I:

The Immediate Postwar Trials and Their ShortTerm Effects 
On the Way to Nuremberg:

The Soviets Commission for the Investigation of Nazi War Crimes

Marina Yu. Sorokina

The "Great Opening" of the Soviet archives after 1991 has given historians a unique chance to study "old" subjects on the basis of "new" archival sources. Rethinking history in this research context-the newly-discovered fact - the archival document often comes into opposition with the existing "official myth" of historiography, whether Soviet, American, German, or other. Very often a new archival document itself and the historical information it contains become the chief protagonists in historical investigations.

The human price paid by the people of the former Soviet Union (USSR) for the Great Victory in World War II was so high-still estimated between 20 and 27 million dead-that for the political stability of the Soviet regime the communist leadership withheld all of the pertinent documentary information and created a special "War Myth." The major metaphors which constitute its internal structure- "unknown soldier," "living and dead," "eternal flame," "victorious people," and so forth-guaranteed that "national oblivion" would serve as an important element in the consolidation of the communist authorities and the Soviet people.

Many Stalinist political myths have gradually been destroyed in modern Russia; however, the "War Myth" has proven to be one of the most resilient, because World War II still occupies a very specific place in the mentality of Russian society. The "Great Patriotic War" (GPW) is regarded as a main historical event in Russian twentieth-century history and is much more present in the minds of Russians than more recent wars (Afghanistan, Chechnya) or even Stalinist repression. Every Soviet/Russian family lost members during the GPW, and because people believe it was a "just war," it plays a very important part in heroic family histories. That is one of the main reasons the Stalinist "War Myth" has even consolidated its position in the Russian public consciousness and academic historiography. In 2005, the sixtieth anniversary of the Great Victory, Georgian producer and writer Rezo Gabriadze produced a puppet play called "The Battle of Stalingrad" which has a very simple and symbolic plot: the unknown sol- 
dier killed in this famous battle of 1943 digs his way out of the grave and tells his story, a metaphor which perfectly describes how individuals and local and professional communities in modern Russia are trying to come to terms with their troubled past.

War crimes and crimes against humanity are among the most sensitive subjects of historical study because of their political, international, cultural, moral, psychological, and scientific ramifications with regard to problems of both history and modernity. The Nazis and Nazism caused unforgettable sorrow to the people of the former Soviet Union, but they had one more powerful enemy-Stalinism - which to this day manages to hide many of its own crimes thanks to the persistence of certain Stalinist official myths. The "idea of Nuremberg" as a metaphor for the priority of legal justice over retribution is not well known in Russia either in the academy or among the general public, and the full textual corpus of the International Military Trial at Nuremberg (IMT, 1945/46) has never been published there. Opposition to the official Soviet narrative regarding Nuremberg remains politically dangerous in Russia, hence it does not attract the attention of Russian academics concerned about their professional careers. ${ }^{1}$

The different degrees of accessibility to Western and Soviet archives during the Cold War era explain why relatively little is known about how the Soviet side of the International Nuremberg Trial was arranged and conducted. ${ }^{2}$ Josef Stalin himself was one of the most persistent lobbyists for the idea of an international trial of fascism beginning in 1942, but why did this political monster insist on the implementation of international law? Who were the authors of the basic legal ideas and procedures used and proposed by Soviets for the Nuremberg Trials? Who composed the whole score and chose the instruments to play? Who distributed these instruments within the orchestra of the Soviet prosecution in Nuremberg and according to what criteria? Was this orchestra really a unified ensemble, or rather an internally conflicted body? What was the constellation of institu-

1 See Bibliografia rabot o Nurnbergskom protcesse nad voennymi prestupnikami (Moscow: Institut gosudarstva i prava, 1986). On a recent international conference held in Moscow and devoted to the sixtieth anniversary of the IMT, see Natalia S. Lebedeva and Yurii M. Korshunov, "Mezdunarodnaia nauchnaia konferentcia 'Nurnbergskii process: uroki istorii," Novaia i noveishaia istoria 2 (2007), 92.

2 A fragmentary picture may be found in Aleksandr I. Poltorak, The Nuremberg Epilogue (Moscow: Progress Publishers, 1971); Natalia S. Lebedeva, Podgotovka Niurnbergskogo protsessa (Moscow: Nauka, 1975). A new account based on various archival sources was just published by Francine Hirsch, "The Soviets at Nuremberg: International Law, Propaganda, and the Making of the Postwar Order," The American Historical Review 113 (June 2008), 701-730. 
tional and personal parts in this orchestra? These and more questions relating to the Soviet side of Nuremberg are still awaiting study.

One way to approach this research is by examining Russian archival holdings relating to the IMT, both personal and institutional collections in the state archives. For example, the heart of the documentary evidence used by the Soviet prosecution at Nuremberg and Tokyo (1950) consisted of the documents collected under the auspices of the Soviet Commission for the Investigation of Nazi War Crimes (ChGK). ${ }^{3}$ In accordance with Article 21 of the Charter of the IMT at Nuremberg, the Commission's files, like official government documents and United Nations reports, had the status of incontrovertible evidence. The 27 "Reports" published by the Commission were widely used in diplomatic notes of the Soviet People's Commissariat of Foreign Affairs (NKID) and at the various Allied peace conferences during the war years; on into the 1960s they continued to be used for domestic Soviet trials of Nazi criminals and their accomplices.

From the moment of its creation, the work of the ChGK and the documents it collected-comprising more than 43,000 files (millions of pages) and located in the State Archive of the Russian Federation (GARF) in Moscow-were under restricted access, although some of the reports were published from time to time in volumes on the history of the GPW supporting the Stalinist "War Myth." Some important Commission documents concerning its inner workings were kept by the central Communist Party archive (now the Russian State Archive for Social and Political History [RGASPI]), including the personal collections of Josef Stalin, People's Commissar of Foreign Affairs Viacheslav Mikhailovich Molotov (18901986), and famous Russian writer and member of the ChGK Aleksei Nikolaevich Tolstoi (1882-1945). ${ }^{4}$ Many ChGK documents are also contained in the Russian Federation's Archive of Foreign Policy in the collections for the secretariats of Molotov and Deputy People's Commissar of Foreign Affairs Andrei Ianuarievich Vyshinskii (1883-1954), who also chaired the se-

3 The full official title is the "Extraordinary State Commission [Chrezvychainaia gosudarstvennaia komissiia] for the Establishment and Investigation of the Crimes of the Fascist German Invaders and Their Accomplices, and of the Damage They Caused to Citizens, Collective Farms (Kolkhozy), Public Organizations, State Enterprises, and Institutions of the USSR."

4 Aleksei Varlamov, who won the Solzhenitsyn Prize for his recent biography of Aleksei Tolstoi (2005), suggests that the death of the writer in 1945 was caused by the horrors of Nazi atrocities he had seen working for the ChGK, but gives no examples. 
cret Commission for Directing the Work of the Soviet Representatives at the IMT in Nuremberg. ${ }^{5}$

Despite the significant public and political repercussions of the ChGK investigations both in the USSR and abroad, its activities attracted independent researchers only a decade ago. ${ }^{6}$ But even after these publications, a series of crucial questions remained unanswered. For instance, why did the Soviet leadership even decide to establish the ChGK when it already had a plethora of agencies concerned with the investigation of, propaganda regarding, and calculation of Nazi damages? Why, despite the enormous mass of information it collected, did the ChGK end up publishing only 27 brief official "Reports" in the years 1943-1945? Why, despite the full politi-

5 Vyshinskii was the former USSR Chief Prosecutor and curator of the Katyn Case. See Iurii Zoria, "Niurnbergskaia missiia," Inkvizitor: Stalinskii prokuror Vyshinskii, ed. and comp. Oleg E. Kutafin (Moscow: Respublika, 1992), 68-284.

6 Some information about the structure and activities of the ChGK appeared in the USSR in 1975 in Natalia S. Lebedeva's Podgotovka Niurnbergskogo protsessa, and twenty years later in Aleksandr Epifanov's Otvetstvennost' gitlerovskih voennykh prestupnikov $i$ ih posobnikov v SSSR (Volgograd: Voennaia Akademia Ministerstva vnutrennikh del Rossii, 1997; 2nd ed. 2005). For more detailed descriptions of the ChGK activities, see Stefan Karner, "Zum Umgang mit der historischen Wahrheit in der Sowjetunion. Die 'Außerordentliche Staatliche Kommission' 1942 bis 1951,” Karntner Landesgeschichte und Archivwissenschaft. Festschrift fur Alfred Ogris zum 60. Geburtstag, ed. W. Wadl (Klagenfurt: Verlag des Geschichtsvereins für Kärnten, 2001), 508-523; Nathalie Moine, "La commission d'enquête soviétique sur les crimes de guerre Nazis: entre reconquête du territoire, écriture du récit de la guerre et usages justiciers," La Mouvement sociale 1 (2008), 81-109; Marina Sorokina, "People and Procedures: Toward a History of the Investigation of Nazi Crimes in the USSR," Kritika: Explorations in Russian and Eurasian History 6.4 (Fall 2005), 797831; Sorokina, “The Nuremberg Witnesses': Ot ankety k biographii,” Pravo na imia: Biografia kak paradigma istoricheskogo protcessa. Vtorye chtenia pamiati V.Iofe. April 16-18, 2004 (SPb.: NITC "Memorial," 2005), 50-63; and Sorokina, "Operatcia 'Umelye ruki', ili Chto akademik Burdenko uvidel v Orle," In Memoriam: Sbornik pamiati Vl. Alloia, eds. Tatiana Pritykina and Oleg Korostelev (Paris: FenixAthenaeum, 2005), 361-389. On the Holocaust investigations of the ChGK see Lev A. Bezymenskii, "Informatsiia po-sovetski," Znamia 5 (1998), 191-199, and "Vospriiatie Kholokosta v Sovetskom Soiuze," Rossiia $i$ sovremennyi mir 4 (1999), 153-168; and Kirill Feferman, "Soviet Investigation of Nazi Crimes in the USSR: Documenting the Holocaust," Journal of Genocide Research 5.4 (December 2003), 587-602. The last article by the well-known historian of the Soviet security service Nikita Petrov does not take into account the works of his predecessors: "Chrezvychainaia gosudarstvennaia komissiia i ee rol' v sudebnykh presledovaniiah vonnoplennykh Vermahta v SSSR. 1943-1950 gg," Avstriitcy i sudetskie nemtcy pered sovetskimi voennymi tribunalami $v$ Belarusi 1945-1950 gg., eds. S.Karner and V.Selemenev (Minsk/Graz 2007), 49-78. 
cal engagement of the ChGK, did its summary document not receive Stalin's permission for publication and thus languish in the ChGK archives? Finally, why did the Soviet leadership — which might have made wide and public use of this documentary evidence to expose Nazism for what it was -instead seal up the archival materials for decades, even from its own people?

The answers must come from future publications. This article takes a more detailed look at the competition between national and international approaches during the creation of the Soviet Nazi War Crimes Commission, including the people involved, and argues that from Stalin's point of view the ChGK did have an important political role to play. In showing Nazism in all its evil dimensions and illustrating the justice of the Soviet struggle against Germany, its main geopolitical mission was to support the Soviet Union's postwar stand as a new global gambler.

\section{1: First Initiatives}

The official history of the Soviet Commission on Nazi War Crimes began on November 2, 1942, when Mikhail Ivanovich Kalinin (1875-1946), chairman of the Praesidium of the Supreme Soviet, signed a decree establishing it. ${ }^{7}$ Nine years later, on June 9, 1951, the commission was terminated by order of the Soviet Council of Ministers, and its documents, staff, and budget were all given to the Soviet Ministry of Internal Affairs (NKVD).

The very idea of establishing a special public agency for the investigation of Nazi war crimes was raised in the USSR at the very beginning of the Great Patriotic War, in August 1941. But it took more than a year to launch it as a policy-making instrument. Four different proposals were based on four different understandings of how to situate the USSR in a larger world. The choice made by the Soviet leadership among the initial proposals and their transformations during this year reflects on the one hand the diversity of personal approaches within the top Soviet politicians and public figures involved, and on the other some of the ways Joseph Stalin intended to reach one of his global political aims: to present his country

7 This decree was published in Pravda 308, November 4, 1942. About Politburo guidance see Politbiuro TsK RKP $(b)-V K P(b)$ : Povestki dnia zasedanii, 1919-1952. Katalog, vol. 3, 1940-1952 (Moscow: ROSSPEN, 2001), 292, \$341. 
after the end of the war as an equal international partner of the Western Allies.

The first proposal regarding the creation of the Soviet Nazi War Crimes Commission appeared as early as August 26, 1941, when its author, Iakov Semenovich Khavinson (1901-1992), director of the Telegraph Agency of the Soviet Union (Telegrafnoe agenstvo Sovetskogo Sojuza; TASS), sent a note to his immediate ideological patron, Aleksandr Sergeevich Shcherbakov (1901-1945), secretary of the Central Committee (CC) of the Soviet Communist Party (SCP) and director of Sovinformbiuro, suggesting the creation of "a wide and authoritative public committee" as a systematic source of information about Nazi crimes in the occupied territories of the USSR. ${ }^{8}$

Khavinson was one of the most experienced and most trusted Soviet journalists and propagandists of that period. He was born to a poor Jewish family in the Ukraine and, like many young persons of his generation and social status, became a member of the Communist Party in 1918, when he was seventeen years old. His professional career was always deeply connected with the Soviet Communist Party and its press. He did not manage to attend a university, but in 1932, after the Great Purge, he was recruited by the CC SCP apparatus in Moscow and became head of its Journal Division (sector zhurnalov). In 1935 Khavinson began to work for one of Stalin's closest collaborators, Andrei Andreevich Zhdanov (1896-1948) in the Leningrad regional SCP Committee (obkom partii), and in 1936 for TASS in Moscow (as director 1939-1943). In 1942 he also became head of the Sovinformbiuro's Department of Counterpropaganda, but after an incident with Stalin in 1943 he found himself an ordinary member of the editorial board and head of the foreign department of the newspaper Pravda until 1946. ${ }^{9}$ Later Khavinson served as Pravda's permanent correspondent for international affairs (under the pseudonym "M. Marinin").

Both editor and censor at the same time, Khavinson, unlike a lot of his Communist Party fellows, managed to survive during the Stalin era, and Stalin's death in 1953 returned him for a while to the top level of Soviet press management. Finally, in 1957 he was appointed editor-in-chief of the newly created and unique special Soviet academic journal dealing with problems of international relations, Mezdunarodnaia ekonomika i mez-

8 Russian State Archive for Social and Political History (RGASPI) f. 17, op. 125, d. $51,1.24-25$.

9 Legend has it that Khavinson was dismissed by Stalin for his ignorance of English. See Piotr Cherkasov, IMEMO. Portret na fone epokhi (Moscow: Ves' mir, 2004), 127. 
dunarodnye otnoshenia (International Economy and International Relations), ${ }^{10}$ which he directed for more than thirty years, till $1987 .{ }^{11}$

The idea proposed by Khavinson in 1941 was not new to Soviets. During World War I the Russian Extraordinary Commission for the Investigation of Violations of the Rules and Customs of War had been created in 1915 under the leadership of Senator Aleksei Nikolaevich Krivtsov, and it was composed of educated people in the legal profession-public and military prosecutors and investigators. Krivtsov's commission made a great show of carefully collecting and organizing all evidence of the enemies' atrocities and published its findings serially, with a legal apparatus, in millions of copies, including excerpts in English, French, and Russian. ${ }^{12}$ In 1917 the Bolshevik Revolution broke off the work of this commission, and its files (over 9000) have never become the subject of scholarly research or public discussion in Russia. ${ }^{13}$

Surprisingly, Khavinson's proposal referred not to this earlier Russian project, but to the Western experience of World War I, when a number of countries organized public committees on atrocities consisting of eminent public figures and representatives of culture, the academy, and law. Suggesting a similar Soviet institution with the aim of international propaganda, Khavinson stressed that the main consumer for the future "product" would be foreign public opinion. The Soviet committee, he said, must similarly include world-famous Soviet scholars, legal experts, doctors, writers, and Red Cross activists whose reputation would guarantee in the eyes of the international public the independence and professionalism of the future committee's evaluations and conclusions. In Khavinson's opinion such persons included USSR Academy of Sciences academicians Nikolai Nilovich Burdenko (physician and committee chair), Aleksandr Aleksandrovich Bogomolets (physician), Piotr Leonidovich Kapitsa (physicist), and Aleksei Nikolaevich Bakh (biochemist); medical professor Maksim Petrovich Konchalovskii; lawyers Nikolai Vasilievich Kommodov, Ilia Davi-

10 Ibid., 125-138.

11 This time Khavinson was dismissed by Evgenii Maksimovich Primakov, director of the Institute for International Economy and International Relations, Minister of Foreign Affairs (1996-1998), and Prime Minister of the Russian Federation (1998/99).

12 See for instance Nashi vragi: Obzor deistvii Chrezvychainoi sledstvennoi komissii dlia rassledovaniia narushenii zakona $i$ obychaev voiny avstro-vengerskimi $i$ germanskimi voiskami, vol. 1 (Petrograd, 1916).

13 The materials can be found in the Russian State Historical Archive (RGIA) f. 601 (Chrezvychainaia sledstvennaia komissia A. Krivtsova). 
dovich Braude, and Sergei Konstantinovich Kaznacheev; writers Sergei Nikolaevich Sergeev-Tsenskii and Aleksei Silych Novikov-Priboi; the director of the House of Scientists, Maria Fedorovna Andreeva; and Soviet People's Artist Alla Konstantinovna Tarasova. delete

Another initiative dealing with the idea of prosecution of Nazi war criminals parallel to Khavinson's came to the Kremlin from the Russian world-famous physicist and director of the USSR Academy of Sciences Institute for Physical Problems academician Piotr Leonidovich Kapitsa (1894-1984), ${ }^{14}$ who, on September 8, 1941, sent his proposal on creation of a public committee for investigation of Nazi war crimes directly to Joseph Stalin. ${ }^{15}$ Kapitsa had spent several years (1921-1934) in Cambridge (UK) working for the Ernest Rutherford Cavendish Laboratory. A Fellow of the Royal Society (1929), when he was on a professional visit to the USSR in the autumn of 1934, he was detained there by Stalin's order and embarked on an intensive correspondence with the tyrant. ${ }^{16} \mathrm{~A}$ man of a great personal courage, Kapitsa publicly defended his views on a variety of subjects, from economics to the organization of science and international scientific exchange. Even in the worst periods of repression he managed to defend his colleagues, saving some of them from death in Stalin's prisons. In November 1945 Kapitsa refused to work on nuclear weapons development, and in 1946 he was dismissed from his post as director of the institute and retired to his country house until after Stalin's death in 1953. The next thirty years of Kapitsa's life were completely devoted to scientific research, and in 1978 he was awarded a Nobel Prize in physics.

Unlike Khavinson, Kapitsa suggested that Stalin establish an international public committee including Allied members known for their contacts with the USSR: Paul de Kruif (1890-1971), the American microbiologist and scientific novelist; John B. Priestley (1894-1984), an English writer, Common Wealth Party leader (1941), and popular broadcaster on the BBC; Hewlett Johnson (1874-1966), the priest at Canterbury Cathedral (the "Red Dean of Canterbury") and a personal friend of the Soviet Ambassador to Great Britain Ivan Mikhailovich Maisky (1884-1975); and Lady

14 See Kapitza in Cambridge and Moscow. Life and letters of a Russian Physicist, eds. J. W. Boag, P.

E. Rubinin, and D. Shoenberg (Amsterdam: North-Holland, 1990).

15 The letter was published twice, in Izvestia TcK KPSS 10 (1990), 216-217, and in Rodina 4 (2005).

16 See Pisma o nauke, 1930-1980, ed. Piotr Rubinin (Moscow: Moskovskii rabochii, 1989), and Kapitza, Kreml' $i$ nauka, eds. Vladimir Esakov and Piotr Rubinin (2 vols., Moscow: Nauka, 2003). 
Nancy Astor (1879-1964), a member of British House of Commons. Kapitsa also recommended Vernon Bartlett (1894-1983), an English journalist and member of Parliament who had been in Moscow at that time, arranging for a better exchange of information between the USSR and the British Commonwealth. ${ }^{17}$

Surprisingly, Kapitsa's letter did not name any Soviet representatives. Perhaps this approach was intended to demonstrate to the "Father of the Nation" the scientist's desire to win influential foreign colleagues over to the Soviet side but at the same time leave the final decision to Stalin himself. In any case, from the remarks on the letter we know that Stalin read Kapitsa's proposal and forwarded it to Viacheslav Molotov, who met with the Kapitsa on September 15, 1941. There is no information about this meeting either, but it is quite clear that Kapitsa's initiative, like Khavinson's, was postponed for some time, perhaps because of the dramatic situation on the military front.

\section{2: New Challenges}

The idea of a public investigation agency was revived in the USSR in the middle of 1942, after the successful Soviet winter offensive of 1941/42 and the July 1942 appeal of the European governments-in-exile to the Allies and the Vatican to take serious notice of the Nazis' atrocities. ${ }^{18}$ In a political sense it grew out of the Soviets' desire to rebuild postwar Europe according to the socialist model, an aspiration which forced the Soviet government to respond to the appeals of the governments-in-exile of the states in Nazi-occupied Europe to stop and punish Nazi war criminals. Already in November 1941 the Soviet government through Viacheslav Molotov had decried the systematic and planned character of German violence in the occupied territories of the Soviet Union and declared the necessity to punish all "Fascists." 19 The Soviets also mentioned that they had been keeping detailed accounts of German crimes, but at that time this was more a declaration of principle than a reality.

17 Later he wrote about his experiences in And Now, Tomorrow (London: Chatto \& Windus, 1960).

18 See the United Nations Information Organisation, Punishment for War Crimes, vol. 1: The Inter-Allied Declaration Signed at St. James's Palace, London, on 13th January, 1942, and Relative Documents ([London]: H.M. Stationery Office, 1942).

19 See Noty narkoma inostrannykh del tovarisha Molotova o germanskih zverstvah (Moscow: Izdatelstvo literatury na inostrannykg iazukah, 1945). 
In the early stages of the war, many Soviet organizations, from local soviets to academic institutions, were involved in collecting information that exposed the war crimes of fascism. Essentially this movement saw the appearance of a broad, organic, popular initiative which was dangerous to the Stalinist regime in its lack of control and regulation, and that was one more reason to be at the head of such spontaneous public initiatives. By the middle of 1942 the People's Commissariats of Defense and Internal Affairs were given the task of channeling, and later of concentrating into their own hands, information about war crimes committed by the Nazis and their accomplices. Finally, it became clear that the war would continue for a long time, and the question of determining the USSR's total wartime losses with the aim of claiming reparations was put on both the international and the national agendas.

By the summer of 1942, when the Western Allies were beginning to discuss the basics of the future United Nations War Crimes Commission, the Soviet leadership had concrete plans to create their own agency. This time the initiative came from the head of the Propaganda and Agitation Department of the SCP CC (Agitprop) Georgii Fedorovich Aleksandrov (19081961). Instead of Khavinson's and Kapitsa's ideas of a "public committee" based on the European model, on July 20 Aleksandrov suggested to his party patrons a draft decree establishing an "Extraordinary State Commission for the Investigation of the Atrocities, Violence, and Other Crimes Committed by the German Army on the Territory of the Temporarily Occupied Soviet Territories, and for a Tallying of the Damage Caused by the German Fascist Troops to the Population of the USSR and to the Soviet State. ${ }^{20}$

A Marxist philosopher by education and Russian nationalist by ideology, Aleksandrov was a rising administrative and political star of the new Stalinist nomenklatura, which replaced the "old Bolsheviks" after the Great Purges of the 1930s. He was a president of the Highest Communist Party University (Vyshaia Partiinaia Shkola) in 1939 and the head of Agitprop from 1940 to 1947, but at the same time, in 1943, he arranged his election to the USSR Academy of Sciences and became a full member of it. ${ }^{21}$ It was a very prudent action. After Stalin's new purge of top Communist Party managers, Aleksandrov survived and from 1947 to 1954 was appointed a director of the Philosophy Institute of the Academy of Sciences. For a brief period in 1954/55 he was nominated the USSR Minister of Cul-

20 RGASPIf. 17, op. 125, d. 79, 1. 9-11.

21 Archive of the Russian Academy of Sciences (ARAN), f. 411, op. 3, d. 228. 
ture. After the promulgation of scandalous facts regarding his personal life in 1955, he was forced to leave both the Communist Party and Moscow, and he spent the last years of his life as a research fellow at the Belorussian Academy of Sciences in Minsk.

Aleksandrov's plan included on the Extraordinary Commission over fifty representatives of the Communist Party and other Soviet institutions - secretaries of the Central Committees of the Ukrainian and Belorussian Communist Parties (Nikita S. Khrushchev, P. K. Ponomarenko), the chairman of the Praesidium of the Supreme Soviet of the Estonian SSR (I. Ia. Vares), the public prosecutor of the USSR (V. M. Bochkov), the Deputy People's Commissars for Internal and Foreign Affairs (I. A. Serov, G. A. Miterev), the RSFSR People's Commissars of Health and Education (V. P. Potemkin, V. G. Dekanozov), the president of the Academy of Sciences of the USSR (V. L. Komarov), two economists (E. S. Varga, V. S. Nemchinov), and a writer (A. N. Tolstoi). This draft was focused on saving the internal stability of the Soviet regime by means of total Communist Party control over any investigations of war crimes, and this aim so overshadowed any other implications of the future institution that Molotov's Commissariat of Foreign Affairs was forced to suggest that Aleksandrov adapt his draft to the goals of Soviet foreign policy as well. Konstantin Aleksandrovich Umanskii (1902-1945), an expert on Western public opinion and a current member of the NKID collegium, was called in to help make Aleksandrov's draft more acceptable to Allied partners.

Umanskii had graduated from Moscow University and in the 1920s and 30s served as a correspondent for TASS Western Europe. He was known as a connoisseur of the Russian avant-garde and painting. Like Khavinson and Aleksandrov, he moved to the NKID apparatus at the beginning of 30s and was the director of the Press Department of NKID until 1939. He then served as ambassador to the United States from 1939 to 1941, and in June 1943 he was named ambassador to Mexico. Two years later, in January 1945 , he died in an airplane crash under very suspicious circumstances.

The divergence of the NKID and CC apparatus views on the function of the future investigative agency was so distinct that the Aleksandrov/Umanskii draft was not ready until the very end of October 1942,22 while U.S. President Franklin D. Roosevelt and British Lord Chancellor John Simon issued a joint statement declaring their readiness to cooperate in the cre-

22 Archive of the Foreign Policy of the Russian Federation of the Ministry of Foreign Affairs of the Russian Federation (AVP RF MID RF) f. 6 (Molotov's secretariat), op. 4, d. 69, file 7 ("On the formation of the ChGK"), 1. 18-24. 
ation of a United Nations commission for the investigation of war crimes on October 7. This declaration forced the Soviets to finish their unilateral discussions and for the first time announce the idea of a "special international tribunal" on fascism. On October 14, Deputy People's Commissar of Foreign Affairs Solomon Abramovich Lozovskii (1878-1952)23 delivered a declaration of the Soviet government "On the responsibility of the Nazi invaders and their accomplices for the atrocities committed by them in the occupied countries of Europe" containing this idea to representatives of the governments of nine countries occupied by the Nazis. ${ }^{24}$

A long-time Communist party member (since 1901), Lozovskii served from 1921 to 1937 as the General-Secretary of Profintern (Internatcional Professional'nykh Sojuzov) and was also a deputy director of Sovinformbiuro beginning in 1941. At NKID he was a leader of a group of Soviet diplomatic managers who promoted close cooperation with Western Allies through all legal and secret channels. It was Lozovskii who in April 1942 initiated the creation of the Jewish Antifascist Committee, because of which he was arrested in 1949 and shot. ${ }^{25}$. Towards the end of the war (summer 1944) he had headed a special Propaganda Bureau for enemy and occupied countries organized within TASS. ${ }^{26}$

On October 29, 1941, Lozovskii, who stayed in Kuibyshev with foreign diplomats but was in charge of establishing the future Soviet Nazi War Crimes Investigation Commission, sent Molotov a telegram with "several names and representatives of public organizations that could be useful to serve the proposed Commission"- the chairmen of the Antifascist Youth, Women's, Scholars', Pan-Slav, and Jewish Committees (Fedorov, V. Grizodubova, N. Derzhavin, A. Gundorov, and S. Mikhoels, respectively)—plus his personal recommendation of the academician P. Kapitsa, the editor of the English-language newspaper The Moscow News M. Borodin, and the editor of the Jewish newspaper Eynikeyt S. Epshtein. The editors of a few

23 RGASPIf. 17, op. 125, d. 244, 1. 103.

24 AVP RF MID RF f. 6, op. 4, d. 65, file 6, 1. 56.

25 See Vasily Grossman and Ilya Erenburg (eds.), The Black Book (Jerusalem: Tarbut, 1970); Shimon Redlich, War, Holocaust, and Stalinism: A Documented Study of the Jewish Anti-Fascist Committee in the USSR (Luxembourg: Harwood Academic Publishers, 1995); and Joshua Rubenstein and Vladimir Naumov (eds.), Stalin's Secret Pogrom: The Postwar Inquisition of the Jewish Anti-Fascist Committee (New Haven, CT: Yale University Press, 2001).

26 RGASPIf. 17, op. 125, d. 244, 1. 103. 
leading Soviet newspapers-Pravda, Izvestiia, Trud, Krasnaia zvezda, and Komsomol'skaia pravda-were also proposed. ${ }^{27}$

Lozovskii's telegram was left in the NKID archive and nothing moved forward because its author (like his "colleague" Aleksandrov-Umanskii) did not clearly understand why Joseph Stalin decided to invest in the ChGK enterprise. Having in mind the idea of "equal" partnership with the Western Allies in the postwar world, he thought about giving international legal legitimacy to the documents that had been both collected and created by the different Soviet agencies. As a result of this cooperation with the Allies, the Soviet leadership began not only to imitate some attributes of the Western political and legal traditions, but even to follow some of them. Hundreds of Soviet specialists in the different fields of law, medicine, art, and science were recruited to work for it. The ChGK had to be one of the Soviet institutions which directly channeled Allies on the base of international law.

\section{The Choice}

Stalin himself chose among all of the proposals relating to the ChGK, and the resulting Soviet Commission on Nazi War Crimes was given the status of a national public independent agency with broad powers: to conduct investigations of Hitler's war crimes and to determine the material damage suffered by the USSR; to coordinate the activities of all Soviet organizations in this field; to reveal the names of war criminals; and to publish official reports on their findings. Almost all of the Soviet and Party functionaries proposed by Aleksandrov were removed from its staff, leaving it reduced to just ten people.

The composition of the Commission had to demonstrate to everyone, both at home and abroad, its public nature and the independence of its investigations and conclusions. Nikolai Mikhailovich Shvernik (1888-1970), head of the Soviet trade unions, was nominated chairman of the Commission, and the other members were famous and popular Soviet figures: the first secretary of the Leningrad city and regional Party committees Andrei Andreevich Zhdanov, a member of the Politburo of the SCP CC; Nikolai (secular name Boris Dorofeevich Iarushevich, 1892-1961), Orthodox Metropolitan of Kiev and Galicia; Valentina Stepanovna Grizodubova (1910-1993), the woman pilot, the chairman of the Anti-Fascist Commit-

27 AVP RF MID RF f. 6, op. 4, d. 69, file 7, 1. 33. 
tee of Soviet Women and Hero of the Soviet Union; and six full members of the USSR Academy of Sciences: the legal scholar Ilia Pavlovich Trainin (1886-1949), writer Alexei Nikolaevich Tolstoi, historian Evgenii Viktorovich Tarle (1875-1955), energy specialist Boris Evgenievich Vedeneev (1884-1946), agrobiologist and president of the USSR Agricultural Academy Trofim Denisovich Lysenko (1898-1976), and neurosurgeon and future president of the USSR Medical Academy Nikolai Nilovich Burdenko (1876-1946).

From Stalin's point of view, the persons nominated as members of the Commission were those best suited at that time to create an official myth. All of them were personally beholden to him and were not only loyal to the Soviet regime, but also in constant communication with it. They perfectly understood that only close collaboration with Soviet authorities would assure them professional freedom. The example of historian Evgenii Tarle is quite telling. ${ }^{28} \mathrm{He}$ was well known in the West as a specialist in European international relations, but in the late 1920s for political reasons he was expelled from the Academy of Sciences and deported to Kazakhstan. In the mid-1930s, upon direct intervention by Stalin, he was allowed to return to Leningrad and regained all his previous academic positions, after which his scholarship was openly supportive of all initiatives of the Stalinist regime. In 1943 he became a member of the People's Commissariat of Foreign Affairs Commission on Treaties and the Post-war Constitution.

The ten public figures at the top were only the visible, propagandistic face of the Commission, which had a complex four-tiered structure. Nominally each member of the ChGK was responsible for one of the departments of the Commission, but in reality the members' oversight was limited to signing final documents. As protocols of the ChGK show, the Commission hardly met, and its protocols were agreed upon by "survey": out of 27 sessions in 1943/44, only four took place as actual gatherings of the members. The activity of the ChGK was actually controlled by its Soviet bosses, who formulated the "political orders" and the apparatus that carried those orders out. This apparatus consisted of the eight departments (investigating damages done to citizens, industry, transport, medicine, science, culture, etc.) and numbered about 150 people-about the size of a

28 See Boris S. Kaganovich's Evgenii Viktorovich Tarle i peterburgskaia shkola istorikov (St. Petersburg: Dmitrii Bulanin, 1995) and "E. V. Tarle v Kommissii po voprosam mirnykh dogovorov i poslevoennogo ustroistva, 1943-1945 gg," Problemy vsemirnoi istorii: Sbornik v chest' akademika A. A. Fursenko, ed. Boris V. Anan'ich (St. Petersburg: Dmitrii Bulanin, 2000), 351-361. 
mid-size Soviet ministry—and was chaired by executive secretary Piotr Bogoiavlenskii.

In accordance with the statutes of the Commission adopted on March 16, 1943, regional and local commissions were created in various republics and regions of the USSR, and there were also departmental commissions set up within institutions. The regional commissions played the most important intermediate role in collecting evidence of Nazi crimes. Their personnel structure differed from that of the central Commission, consisting of the First Secretary of the regional Communist Party committee, heads of the local government and regional NKVD, and so-called "representatives of the general public." By the beginning of 1944 there were nineteen regional commissions in operation, and it is quite clear that control over their activities was in the hands of the NKVD. At the same time, every institution, from the Academy of Sciences to small factories, also created departmental commissions. And finally, a number of "special" commissions were founded from time to time within the central ChGK (like the one that focused on the Katyn Case). According to the calculations of the ChGK, more than 7 million Soviet citizens were directly involved in collecting and preparing documents for submission to the Central Commission.

The ChGK had both a right and an obligation to collect written evidence of Nazi war crimes (e.g., German military, scientific, and medical documents) and oral testimony from victims and witnesses for the prosecution, and also to publish this information, which was collected at the different levels, summarized in special statements (akty), and then passed on to the Central Commission. The content and form of these statements were regulated by special instructions adopted on May 31, 1943, which determined the documentary base and sources necessary to establish the fact that crime had been committed-statements from Soviet citizens, questioning of victims, testimony of witnesses, reports of medical inquests, and inspections of the crime scenes. These instructions provided for the drawing-up of lists of the names of war criminals and their associates, the naming of military formations and organizations involved in committing crimes, and detailed description of the crimes committed. The full names of all victims and witnesses had to be included in the statement and any pertinent documentation - protocols of questioning, depositions by victims, findings of medical inquests, pictures, letters, German documents, etc.- -attached, and every statement had to be drawn up at the precise location of the crime within a month of the district being liberated by the Red Army. 
In reality these stipulations of terms and procedures were never carried out exactly, but more important for a critical evaluation of these materials as a historical source is the fact that the members of the regional and departmental commissions knew that any future compensation to be paid to their institutions or regions would be determined on the basis of these statements. Full monetary calculation of material damages was paramount -and usually very high. The local commissions were psychologically predisposed to inflate the cost of damage done, though at the same time the Soviet bureaucrats never did consider the real value of intellectual losses such as scientific equipment and collections.

Organizing the ChGK took more than four months, but the beginning of the Katyn Case in April 1943, and concern regarding its political implications, combined with the need to restore ideological control over the territories that had either already been freed or were in the process of being freed, spurred the Soviet leadership to hasten the process.

Amazingly, despite having collected a vast amount of information during the war, from 1943 to 1945 the Soviet Commission on Nazi War Crimes published only twenty-seven brief reports and two volumes of documents, which were for the most part based on these same previously published reports. ${ }^{29}$ At first the Commission's reports were published in the central Soviet newspapers Pravda and Izvestiia, and then in special editions of 100,000 copies each. They covered such themes as the crimes of Finnish troops in the territory of Finno-Karelian SSR (1944) and Nazi crimes in various Soviet areas, including Ukrainian cities (Rovno, Kiev, Kharkov, L'vov), Belorussia (Minsk), Russian cities (Novgorod, Orel, Smolensk, etc.), the North Caucasus, and the Soviet Baltic Republics (Lithuania, Latvia, and Estonia). Clearly the direct aim of Soviet propaganda was to demonstrate that Nazi crimes affected all parts of the Soviet Union, including states and territories annexed from 1939 to 1941 . Every area and every case had been carefully selected for these reports by the Soviet authorities. Andrei Zhdanov and Viacheslav Molotov had personally edited the ChGK reports of damages in Petrodvoretc, Pushkin, and Pavlovsk; Molotov and Andrei Vyshinskii those for Minsk; and permission to publish some of the reports was given personally by Joseph Stalin. ${ }^{30}$

29 See Sbornik soobshchenii Chrezvychainoi Gosudarstvennoi Komissii o zlodeianiiakh nemetskofashistskikh zakhvatchikov (Moscow: Gosudarstvennoe izdatel'stvo politicheskoi literatury, 1946) and Dokumenty obviniaut: Sbornik dokumentov (2 vols., Moscow: Gosudarstvennoe izdatel'stvo politicheskoi literatury, 1943-1945).

30 See the State Archive of the Russian Federation (GARF), f. R-7021 op. 116, d. 65, $67,131-32$, and 247 respectively. 
The activities of the Soviet Commission on Nazi War Crimes did not stop with the end of World War II. During the second half of the 1940s the ChGK exchanged information with the Soviet Military Administration in Germany and took part in Soviet activities dealing with the problems of reparations and restitution, ${ }^{31}$ and during the Cold War era Soviet authorities revived it from time to time for propaganda purposes. ${ }^{32}$ However, the real contribution of the ChGK in the collecting and investigating of Nazi war crimes during this period was negligible. Soviet security agencies (NKVD-KGB) concentrated all information in their own hands, the Commission archives were closed to the public, and no one knew what would appear or when from this Pandora's Box.

Today it is clear that Stalin's plan to create a phantom "public prosecutor" of fascism was successful primarily for domestic aims. The ChGK fulfilled its representational function during the war years and postwar trials, and faithfully kept the subject of war crimes sealed off from Soviet society, but for decades the society itself refused to re-visit the negative experience of the past. The history of World War II-the "Great Patriotic War"proved to be no exception to the list of losses that were forgotten and discarded by the country.

31 GARF, f. R-7021 op. 116, d. 247.

32 The last Commission protocol, No. 73, was dated March 28, 1960 (GARF, f. R-7021 op. 116, d. 390), but the regional archives sent information to the Commission until 1969 (d. 409). 


\title{
German Participation in the Nuremberg Trials and Its Implications for Today
}

\author{
Christoph J. M. Safferling
}

The changing German perspective on the Nuremberg legacy over the last ten to fifteen years is best expressed by two quotations. Wilhelm G. Grewe (1911-2000), a German diplomat and scholar, wrote in 1985 (English translation 2000):

Hopes and expectations that were nourished in 1945 and the subsequent year and inspired by the models of the International Military Tribunals of Nuremberg and Tokyo, were illusory from the very beginning. These models could only impress zealots and starry-eyed idealists who were blind or dazzled by the realities of world politics. ${ }^{1}$

In contrast, Hans-Peter Kaul, also a German diplomat and the first German judge at the International Criminal Court (ICC), stated in an interview in 2003: "The Nuremberg Trials have initiated a process that is irreversible and at the end of which now stands the ICC." ${ }^{2}$ There are not even twenty years between these comments by two Germans, and they could not be more opposite.

This article is divided into three sections: the first describes and explains this change in attitude and includes a few words on the recognition of the Nuremberg Trials at the time they took place and in the aftermath; the second is a discussion of the swing together soon after unification in 1990, with the sudden rebirth of international criminal law through the establishing of the ad hoc Tribunal for the Former Yugoslavia (ICTY) by the UN Security Council; and the third is a summary of the situation in which we are today, sixty years after the beginning of the trials against the major war criminals in Nuremberg.

1 Wilhelm G. Grewe, The Epochs of International Law (Berlin: DeGruyter, 2000), 667.

2 See www.auswaertiges-amt.de/www/de/ausgabearchiv?archivid=3357. See also Hans-Peter Kaul, "Der Beitrag Deutschlands zum Völkerstrafrecht," Völkerstrafrechtspolitik, eds. Christoph Safferling and Stefan Kirsch (Heidelberg: Springer, 2014), 51-84. 


\section{The Attitude towards the International Military Tribunal in Nuremberg during and for Forty Years after the Trials}

The German public did not follow the trials in Nuremberg closely for several reasons. First of all, people were primarily busy with organizing everyday life in the agonizing postwar environment, and second, the ability of the media to inform the public was limited due to the destruction in the country. ${ }^{3}$ Nevertheless, the Nuremberg Trials made the front page in newspapers and during the "Wochenschau" in cinemas. ${ }^{4}$ There was considerable anger amongst the population toward the Nazi leaders, who were considered responsible for the disastrous situation and the total collapse of civilization and therefore deserving of punishment. Around $80 \%$ of the German population thought the Nuremberg Trials were fair and just; a mere $6 \%$ were critical, and some $9 \%$ thought the judgments were too harsh. ${ }^{5}$

German academia ignored the trials altogether at the time, because the general sentiment was that it was politically unwise to address them. With all necessary caution I must say that a considerable number of German law professors in the 1930s had known exactly what the Nazi Party wanted to hear and wrote accordingly in the hope of receiving swift promotion. This was particularly true in the so-called Kieler Schule, where in the early $1930 \mathrm{~s}$ young law professors tried to "harmonize" Nazi ideology and jurisprudence in their teaching and writing at the University of Kiel. ${ }^{6}$ On the other hand, in 1946 and subsequent years, when the denazification process was under way, it was considered wise to do, without criticism, what was expected by the Allies.

At the beginning of the 1950s, German opinions about the Nuremberg Trials were quite diverse: about $30 \%$ thought they were unfair, $40 \%$

3 Gerhard E. Gründler and Arnim von Manikowsky, Das Gericht der Sieger (Oldenburg/Hamburg: Gerhard Stalling Verlag, 1967), 10.

4 Because no one had a television set, special weekly newsreels were shown prior to the main film in theaters, a feature actually introduced by the Nazi public relations specialists during the Third Reich.

5 See Albin Eser, "Das Internationale Militärtribunal von Nürnberg aus deutscher Perspektive" ("The International Military Tribunal at Nuremberg from a German Perspective"), The Nuremberg Trials: International Criminal Law Since 1945, eds. Herbert R. Reginbogin, Christoph J. M. Safferling and Walter R. Hippel (Munich: Saur, 2006), 53-59.

6 See Jörn Eckert, "Was war die Kieler Schule?," Recht und Rechtslehre im Nationalsozialismus, ed. Franz Jürgen Säcker (Baden-Baden: Nomos, 1992), 37-70; and Bernd Rüthers, Entartetes Recht. Rechtslehre und Kronjuristen im Dritten Reich (Munich: C. H. Beck, 1988), 42-48. 
thought the judgments were too harsh, and 50\% said the Allies dealt with the German war criminals in the wrong way. ${ }^{7}$ After denazification slowed down, there was a tendency among Germans to avoid thinking about the past, particularly the Nazi regime. The Nuremberg Trials were seen as "victor's justice" ("Siegerjustiz"), organized by hypocritical victorious states that had been just as responsible for war crimes and crimes against peace as the Germans. ${ }^{8}$ At the same time, the Western Allies were pushing for a strong West Germany as a bulwark against Communism. ${ }^{9}$

This dramatic shift in attitude can be observed in several instances. Here I want to address several legal difficulties that were raised at the Nuremberg Trials and then focus on subsequent trials in West Germany and East Germany.

\section{Problems with the Nuremberg Trial}

The first difficulty was that the Anglo-American criminal procedure was foreign to the German lawyers, and they questioned its fairness. Also, while the defense lawyers ${ }^{10}$ could cope with the adversarial structure of the proceedings, against the prosecution-the U.S. team alone consisted of more than two hundred members - the defense teams seemed rather helpless. ${ }^{11}$ This latter criticism would have value in most criminal trials and describes a structural deficiency in general, and the discrepancy in means between the prosecution and the defense seems much larger in the Continental inquisitorial trial system than in the Anglo-American system. ${ }^{12}$ The former point, however - that the American procedure was foreign to the Ger-

7 See Eser, "Das Internationale Militärtribunal von Nürnberg," 57.

8 See Knut Ipsen, Völkerrecht (5th ed., Munich: C. H. Beck, 2004), $\$ 42$ MN 18.

9 See Norbert Frei, Vergangenheitspolitik. Die Anfänge der Bundesrepublik und die NSVergangenheit, (paperback 1st ed., Munich: C. H. Beck, 1999).

10 An overall analysis of the defence at Nuremberg is given by: Hubert Seliger, Politische Anwälte? Die Verteidiger der Nürnberger Prozesse (Baden-Baden: Nomos, 2014).

11 Klaus Kastner, Die Völker klagen an (Darmstadt: Primus, 2005); see also Benedikt Salleck, Strafverteidigung in den Nürnberger Prozessen (Berlin: Duncker \& Humblot, 2016).

12 For a structural comparative analysis of German and Anglo-American criminal procedures, see Christoph J. M. Safferling, Towards an International Criminal Procedure (Oxford: Oxford University Press, 2003), 54ff. 
man defense lawyers-cannot be maintained. ${ }^{13}$ The German defense lawyers acted as professionally as they could and learned to use, for example, the cross-examination feature-although one could say that it backfired dramatically when the defense called Rudolf Höss into the witness box. ${ }^{14}$

Another criticism of the Nuremberg Trials concerned the question of whether military leaders can be held responsible for political decisions. The defense, and in particular Professor Hermann Jahrreiß, who was the defense lawyer for Alfred Jodl, Commander in Chief of the German Wehrmacht, pleaded that a military leader follows orders but is not responsible for the political decision to go to war. ${ }^{15}$ The great military virtues of "Treue" and "Ehre" were extolled; loyalty and honor were demonstrated by fulfilling the oath every German soldier swore to the "Führer," after all. This discussion, old-fashioned as it may seem, is still vital in Germany and reached a late peak when in 1995 the Hamburg Institute for Social Science sponsored research by the well-known sociologist Jan Reemtsma into the crimes of the Wehrmacht. The resulting exhibition, "Dimensionen des Vernichtungskrieges 1941-1944," caused a real uproar among the general public. ${ }^{16}$ "Treue" and "Ehre" are all very well in principle, but the Nazi regime perverted this principle, and the SS and members of the Wehrmacht were willing to pursue an immoral war through immoral means in ruthless pursuit of "honor."

Perhaps the most important legal issue, however, was the violation of nullum crimen sine lege, the principle of non-retroactivity. The claim that the Nuremberg Trials violated this principle pertains in particular to the

13 Compare the treatise of the former Nuremberg defence counsel Otto Kranzbühler, Rückblick auf Nürnberg (Hamburg: Zeit Verlag, 1949), who offers a fairly balanced criticism of the Nuremberg Trials concerning the fairness of the proceedings.

14 See Whitney R. Harris, Murder by the Millions. Rudolf Hoess at Auschwitz (Jamestown, NY: The Robert H. Jackson Center, 2005).

15 Hermann Jahrreiß, "Der Bruch des zwischenstaatlichen Friedens und seine Strafbarkeit, Plädoyer vor dem Internationalen Militärgerichtshof zu Nürnberg," Der Prozess gegen die Hauptkriegsverbrecher vor dem Internationalen Militärgerichtshof (Berlin: Rütten \& Loening, 1946), 53ff.; see also Otto Kranzbühler, "Die Kriegsverbrechergesetzgebung von Nürnberg als Rechtsproblem," Festschrift für Erich Kaufmann (Stuttgart: Kohlhammer, 1950), 219-226.

16 See Jan Philipp Reemtsma, Verbrechen der Wehrmacht. Dimensionen des Vernichtungskrieges 1941-1944. Ausstellungskatalog (2nd ed., Hamburg: Institut für Sozialforschung, 2002). 
crime against peace. ${ }^{17}$ The other crimes, such as war crimes and crimes against humanity, are in truth relatively unproblematical with regard to the principle of non-retroactivity. ${ }^{18}$ Informed people know this, but to the general public the entire prosecution was a violation of this principle. West Germany made the principle of non-retroactivity highly prominent place in its constitution; Art. 103 Abs. 2 GG reads: "An act may be punished only if it was defined by a law as a criminal offense before the act was committed." 19 This principle is essential for the rule of law ("Rechtsstaat"), but sometimes I have the impression that it is carried as a categorical icon and is misused to excuse highly immoral acts on merely formal grounds. ${ }^{20}$

The European Convention on Human Rights, an extremely successful instrument in promoting the rule of law and respect for human rights in Europe, incorporated the provision against retroactive prosecution in Article $7 \$ 2$. When it was drafted in 1950 , the memory of Nuremberg was still vivid, hence an exception was inserted for heinous atrocities which violate the conscience of humanity. The young West German democracy was cautious enough to implement a reservation to this exception, despite the fact that Gustav Radbruch, the pre-Nazi German Reichsminister for Justice, claimed that highly unjust laws cannot justify criminal acts. ${ }^{21}$ This reservation is a clear and unequivocal sign of mistrust against the proceedings at Nuremberg. 22

Another flaw that was seen in the Nuremberg Trials was the fact that German victims were not made an issue. The cases that were brought before German courts after they were reopened later in 1945 and in the following years, could not make up for this lacuna. ${ }^{23}$ True, the Allies were primarily interested in prosecuting the major war criminals for the atrocities they committed on their territory and to punish them for the suffering

17 See, e.g., Hans-Heinrich Jescheck and Thomas Weigend, Strafrecht. Allgemeiner Teil (5th ed., Berlin: Duncker \& Humblot, 1996), 120.

18 See Gerhard Werle, Völkerstrafrecht (Tübingen: Mohr Siebeck, 2003), MN 25.

19 For a full English version of the German Grundgesetz, see http://www.iuscomp.org /gla/statutes/GG.htm.

20 See Werle, Völkerstrafrecht, MN 27-28. See especially the laconic comments by Winfried Hassemer and Walter Kargl, Nomos Kommentar StGB (2nd ed., BadenBaden: Nomos, 2005), $\$ 1$ MN 11.

21 Gustav Radbruch, "Gesetzliches Unrecht und übergesetzliches Recht," Süddeutsche Juristen Zeitung [1947], 634.

22 See Jens Meyer-Ladewig, EMRK-Handkommentar (Baden-Baden: Nomos, 2003), Art. 7 MN 11-12.

23 See Hans-Christian Jasch and Wolf Kaiser, Der Holocaust vor deutschen Gerichten. Amnestieren, Verdrängen, Bestrafen (Stuttgart: Reclam 2017), 35 et subs. 
among their people. The United States, on the other hand, was mostly interested in developing the crime of aggression and building a new world order on this, and the suffering of the German people before the war was ignored. Justice Jackson tried to establish a broad crime of conspiracy, which would have comprised this as well, but he did not succeed in the pre-Nuremberg diplomatic struggle to draft a statute for the IMT. It remains a pity that the persecution of Jews and other minorities living in Germany was not made a topic at Nuremberg. We still stand in shock at this terrible loss: through the Holocaust Germans eliminated the most talented, musical, artistic, literate part of its population.

\section{Prosecution of Nazis in West-Germany}

A look at the prosecution of Nazi criminals in West Germany after 1950 shows how astonishingly few prosecutions were brought forward and how very reluctantly courts convicted. ${ }^{24}$ Most of the proceedings that took place were carried by a strong sense of self-justification and understanding for the criminals. Whereas some of the most brutal SS-murderers were convicted and sentenced, those who had sat at their office desks and were responsible for planning and ordering the Holocaust were let off the hook. The German High Court of Justice achieved this by taking a strict subjective approach towards acting and abetting, and the outcome was as follows: the "Führer," together with his "gang," Himmler and Heydrich, was held criminally responsible for the death of millions of Jews, Gypsies, and others, while members of the administration, e.g., in the Reichssicherheitsamt, the office for home security, could only be prosecuted for abetting murder. Of course, abetting a crime is still a crime, but the sentence is far more lenient. Since the extradition of John Demjanjuk to Germany and his conviction by the Regional Court of Munich II, several cases against former guards at Auschwitz and other concentration camps have been

24 Statistical material can be found in Adalbert Rückerl, Die Strafverfolgung von NSVerbrechen 1945-1978 (Karlsruhe: C. F. Müller, 1979). See also Rebecca Wittmann, "The Normalization of Nazi Crime in Postwar West German Trials," The Nuremberg Trials: International Criminal Law Since 1945, eds. Herbert R. Reginbogin, Christoph J. M. Safferling and Walter R. Hippel (Munich: Saur, 2006), 209-215; Michael Bazyler, Holocaust, Genocide, and the Law. A Quest for Justice in a Post-Holocaust World (Oxford: OUP 2016), 109 et subs. 
prosecuted and are still beeing prosecuted in 2019. ${ }^{25}$ Most prominent amongst them was the conviction against Oskar Gröning, which was upheld by the German High Court of Justice. ${ }^{26}$

The same must be said of the prosecution of former Nazi judges. There is a criminal norm called "perversion of justice" by virtue of which judges can be held responsible for handing down arbitrary judgments. ${ }^{27}$ Here again the post-1950 High Court of Justice in Germany adopted the extreme subjective approach, and in the end, those judges who energetically flexed and bent the law in order to bring Nazi ideology and politics to reality, who sentenced to death thousands of innocent victims in blatant breach of any known legal methodology, were acquitted because they had acted in accordance with their convictions and believed they were fulfilling the law. ${ }^{28}$

Overall, German jurisprudence at the time seems to have been aiming at a "biological" solution to the problem of Nazi crimes: "Aussitzen"-basically sitting and waiting until the storm was over. ${ }^{29}$ However, criminal prosecution did have an impact on German society, especially the so-called Auschwitz Trial. ${ }^{30}$ The then General Attorney of the state of Hesse Fritz Baur, who was of Jewish origin and survived the Nazi regime in exile in Scandinavia, initiated a trial against twenty Auschwitz perpetrators, from guards to the commander, in 1963. This trial lasted for two years and re-

25 See Lawrence Douglas, The right wrong man. John Demjanjuk and the last great Nazi war crimes trial (Princeton: Princeton University Press, 2016).

26 See the collection of articles on the "last trials" against Nazi-criminals: Frank Lüttig and Jens Lehmann, Die letzten NS-Verfahren. Genugtuung für Opfer und Angehörige - Schwierigkeiten und Versäumnisse der Strafverfolgung (Baden-Baden: Nomos 2017).

27 "Section 339, Perversion of the Course of Justice: A judge, another public official, or an arbitrator, who in conducting or deciding a legal matter makes himself guilty of a perversion of the course of justice for the benefit, or to the detriment, of a party, shall be punished with imprisonment from one year to five years." The full text of the German Criminal Code in English can be found at http://www.ius comp.org/gla/statutes/StGB.htm.

28 Most dramatic in this regard was the acquittal of the former Judge at the Volksgerichtshof (The Peoples Court) Hans-Joachim Rehse, Bundesgerichtshof, 30 April 1968 - 5 StR 670/67, Neue Juristische Wochenschrift (1968), 1339.

29 See Bernhard Schlink, Vergangenheitsschuld und gegenwärtiges Recht (Frankfurt a. M.: Suhrkamp, 2002), 14.

30 See Gerhard Werle and Thomas Wandres, Auschwitz vor Gericht. Völkermord und bundesdeutsche Strafjustiz (Munich: C. H. Beck, 1995); and Rebecca Wittmann, Beyond Justice: The Auschwitz Trial (Cambridge, MA: Harvard University Press, 2005). 
ceived considerable media attention-in fact it was primarily through this coverage that Germany was finally shown publicly what had really happened in Auschwitz. ${ }^{31}$ Commentator Professor Micha Brumlik concludes: "What West German society put aside, what politics couldn't do, what historiography was neither willing nor able to do-investigate the systematic mass murder committed by Germans-this was done by the Courts". 32 Nevertheless, the overall outcome of the trial fitted into the general trend; Rebecca Wittman rightly observes: "The German public learned to chastise and denounce the sadistic 'excess perpetrator' of Auschwitz, and to forgive the order-followers." 33

In this context the question arises, how could the German people in general be so ready to forgive? Was there no moral sentiment of sorrow? Was there no collective grief? Germany had experienced total breakdown on May 8, 1945; however, due to political necessity West Germany had to be brought back to some strength, because the border between the Western and the Eastern Blocs divided the country. ${ }^{34}$ But where were the personnel that would occupy the posts of the new German jurisdiction? Any new German judge was supposed to be anti- or at least non-Nazi.

It is ironic and tragic at the same time, but German society was so completely infiltrated by National Socialism that it was simply impossible to find enough such people without waiting for an entire new generation. In the end many-too many-former obedient Nazi judges served as democratic judges, despite having actively supported or at least tolerated the Nazi ideology for twelve years. In some regions of Germany all of the pre-1945 judges kept their posts or were re-introduced into the judiciary. ${ }^{35}$

31 The Auschwitz trial and Fritz Baur have drawn much attention in Germany in the last ten years. Three movies have been produced, internationally most prominent amongst them, the Film "Labyrinth of Lies" by Alexander Fehling in 2013; new biographies were written on Fritz Bauer, like Ronen Steinke: Fritz Bauer: oder Auschwitz vor Gericht (Munich: Piper 2013); and Irmtrud Wojak, Fritz Bauer 19031968. Eine Biographie (Munich: C. H. Beck, 2011).

32 Micha Brumlik, "Die Deutschen und der Auschwitz-Prozess," Frankfurter Rundschau, September 27, 2002.

33 Wittmann, Beyond Justice.

34 See Kim Priemel, The Betrayal. The Nuremberg Trials and German Divergence (Oxford: OUP, 2016), 368 et subs.

35 Hinrich Rüping, "Zwischen Recht und Politik: Die Ahndung von NS-Taten in beiden deutschen Staaten nach 1945" "Between Law and Politics: The Prosecution of NS-Criminals in the Two German States after 1945"), The Nuremberg Trials: International Criminal Law Since 1945, eds. Herbert R. Reginbogin, Christoph J. M. Safferling and Walter R. Hippel (Munich: Saur, 2006), 199 -208; see also Wittmann, Beyond Justice. 
The question of lustration after the Nazi-regime was brought to the public attention in Germany starting in 2010 and has given rise to many commissions of experts established by federal agencies and ministries in order to research the history of the respective government institutions and their dealing with the Nazi-past. The process is still ongoing in $2019 .{ }^{36}$

And what could one expect from such a judiciary? Psychologically, the attempt to exonerate former Nazi criminals is quite understandable, because in this way the judges could exonerate themselves a little. The more understanding they showed in the trials against former Nazis, the better the light in which they themselves stood. ${ }^{37}$ It is hard to be called to judge as an outsider when in truth you are much more of an insider.

\section{Prosecution of Nazis in East Germany}

The Soviet occupied zone, which became the German Democratic Republic, had a different story. ${ }^{38}$ The "socialist" system that was established there claimed to be founded on anti-fascism and started out to prosecute former Nazi war criminals, but soon the shadow of a new suppressive systemcommunism-overlay any genuine attempt to come to terms with the past. Trials were utilized by the Party of Socialist Unity (SED) to get rid of persons who were unwilling to cooperate with it. The socialist state proclaimed that, unlike West Germany, it was not a successor to the fascist German Reich and thus was not responsible for atrocities committed by the Nazis and their followers. ${ }^{39}$

Before long the Socialist Party in East Germany had established a system which was just as repressive as the Nazis' secret police. And people lived

36 For a comprehensive summary, see: Christian Mentel and Niels Weise, Die Zentralen Deutschen Behörden und der Nationalsozialismus. Stand und Perspektiven der Forschung (Munich/Berlin: Institut für Zeitgeschichte, 2016). The present author was involved in such a commission of experts established by the Ministry of Justice, see: Manfred Görtemaker and Christoph Safferling, Die Akte Rosenburg. Das Bundesjustizministerium und die NS-Zeit (Munich: C. H. Beck, 2016).

37 See Schlink, Vergangenheitsschuld und gegenwärtiges Recht, $30 \mathrm{ff}$.

38 There has not been much research on this issue, but a compilation can be found in Rüping, "Zwischen Recht und Politik," 203ff.; but see now: Jasch and Kaiser, Der Holocaust vor deutschen Gerichten, 41 and 182.

39 A comprehensive comparison between West and East German dealing with the past, see: Frank Bösch and Andreas Wirsching, Hüter der Ordnung. Die Innenministerien in Bonn und Ost-Berlin nach dem Nationalsozialismus (Göttingen: Wallenstein, 2018), 13. 
with this for almost forty years. Then a miracle happened. In a totally peaceful revolution the East German population, usually perceived as rather phlegmatic, freed itself from the socialist burden by crying out: "We are the people!" On November 9, 1989, the Berlin Wall broke down just as former U.S. President Ronald Reagan had called on Soviet President Gorbachev to do. In an extremely emotional time Germany became a unified nation, and forty-five years after the end of World War II the 2+4 Treaty of 1990 was something like a peace treaty.

\section{The Attitude after German Unification}

Unification brought a change. Germany was forced to address the issue of Nazi crimes again because several German companies were sued for compensation of forced labor during the Third Reich. After a long, distressing legal and political struggle a foundation was established called "Remembrance, Responsibility, and Future," with an overall sum of five billion Euros to compensate for human rights atrocities committed by private enterprises which were part of the German war industry. It was much too late, of course, and a bit too much pressure was needed, and an acknowledgment of the actual legal claim was never achieved, but the payment of some money is a symbolic gesture expressing some moral responsibility. ${ }^{40}$

Unification brought back to general attention the problem of how to deal with systematic crimes, crimes ordered and supported by the state. In particular the so-called "Mauerschützen," i.e., the killings of trespassers by border guards, became test cases for the criminal justice system in Germany. ${ }^{41}$ Now the German judiciary proved ready and able to solve the legal issues it had been hindered from prosecuting in the preceding decades. Statutory limitations were not seen as a problem, because time had basically started again on Unity Day, October 3, 1990. Nor was the retroactivity principle seen as a problem, because any East German law that justified

40 See, e.g., Peer Zumbansen (ed.), NS-Forced Labor: Remembrance and Responsibility. Legal and Historical Observation (Baden-Baden: Nomos, 2002). See also Christoph J. M. Safferling, "Zwangsarbeiterentschädigung und Grundgesetz," Kritische Justiz 34 (2001), 208.

41 The first "Mauerschützenfall": 39 BGHSt 1. An English translation of the first decision of the Bundesgerichtshof (High Court of Justice) can be found in: 100 ILR 364 (1995). See also the case against the former Party Council Members 48 BGHSt 77; 95 BVerfGE 96; and ECHR Streletz, Kessler, Krenz v. Germany, March 22, 2001, Reports 2001-II. 
killing a border-trespasser would be void in accordance with the Radbruch Formula. ${ }^{42}$

Was it again "victor's justice" when West Germany, on the victorious side of the Cold War, prosecuted East Germans? Further, did the West German judiciary try, as suggested by Bernhard Schlink, a constitutional lawyer, to compensate for earlier omissions regarding the prosecution of Nazi crimes?43

Another factor that influenced the development of the new German position on international criminal law was the horrible war in the Balkans in the first half of the 1990s, with incredible suffering among the civilian population and constant reports of genocide and crimes against humanity. The term "ethnic cleansing" was crafted to explain the atrocities in what used to be Yugoslavia. It came as something of a surprise, but the UN Security Council decided to establish the International Criminal Tribunal for the former Yugoslavia (ICTY), bowing to the idea of Nuremberg and setting up an international tribunal to prosecute crimes against so many innocent victims. And Germany was right in the middle of it all, because more than a few war criminals tried to escape from Yugoslav territory and find a safe haven there. The German Federal Prosecutor, however, reacted swiftly and charged these criminals with war crimes and genocide, and brought them before German courts on the basis of the principle of universality. ${ }^{44}$

One of the first to be arrested and indicted was Duško Tadić, who was later summoned by the ICTY and extradited to the UN Tribunal virtually on the eve of the day that he was supposed to stand trial before the High Court of Bavaria. It should be emphasized that in this case extradition was a complicated matter for Germany for constitutional reasons. The ICTY as

42 See Radbruch, "Gesetzliches Unrecht und übergesetzliches Recht”. See also Ralph Grunewald and Christoph J. M. Safferling, "Bundesgerichtshof in Strafsachen 2002/2003," Annual of German and European Law 2/3 (2004/2005), 378-398. The matter of "Perversion of Justice" according to Criminal Code $\$ 339$ was relevant again to prosecute SED-judges. Whereas the Federal Court of Justice abandoned the strictly subjective approach it applied to Nazi-judges, very few East German judges were convicted due to an overall restrictive interpretation of the norm. See Dirk Quasten, Die Judikatur des Bundesgerichtshofs zur Rechtsbeugung im NS-Staat und in der DDR (Berlin: Duncker \& Humblot, 2003).

43 Schlink, Vergangenheitsschuld und gegenwärtiges Recht, $39 \mathrm{ff}$.

44 See, e.g., Cristina Hoß and Russel Miller, "German Federal Constitutional Court and Bosnian War Crimes," German Yearbook for International Law 44 (2001), 576; and Christoph J. M. Safferling, "Prosecutor v Djajic", Neue Juristische Wochenschrift 51 (1998), 392, and American Journal of International Law 92 (1998), 528. 
an ad hoc tribunal was established ex post facto and the Grundgesetz, the German Constitution, prohibits such exceptional courts ("Ausnahmegerichte"). ${ }^{45}$ But the German government shelved constitutional doubts and passed legislation according to which Tadić could be transferred to The Hague.

The case of Tadić became in effect the test case for the ICTY. All the important questions regarding jurisdiction, retroactivity, and so forth were raised at this trial, and again something remarkable happened: in its first ever decision of October 2, 1995, ${ }^{46}$ the Appeals Chamber developed what Claus Kress, professor of German International Criminal Law at Cologne University and a great proponent of modern international criminal law in Germany, calls the "second generation of international crimes". ${ }^{47}$ With this term he tries to grasp the shift away from an international criminal law that is applicable only to international armed conflicts to international criminal law with a wider scope.

Since this decision the concepts of crimes against humanity and war crimes are also applicable in part to purely internal conflicts. ${ }^{48}$ In its decision the Appeals Chamber referred to the Nuremberg judgments over and over again in order to buttress its arguments in favor of a wider view of customary law for war crimes in internal conflicts. At the Conference "Judging Nuremberg" on July 19, 2005, Claus Kress said: "Therefore a government that insists that the principle of non-retroactivity needs to be applied in full force to crucial cases in public international law, too, would have had reasons to criticize the Tadic jurisprudence." ${ }^{49}$ At the same conference the German Undersecretary of Justice, Hansjörg Geiger, emphasized in his address the importance of the Tadic trial and the positive role Germany played in it. In the meantime, the German government under

45 Article 101 of the Grundgesetz reads as follows: “(1) Extraordinary courts shall not be allowed. No one may be removed from the jurisdiction of his lawful judge. (2) Courts for particular fields of law may be established only by a law."

46 ICTY Prosecutor v. Duško Tadić, Case No. IT-94-1-AR72, October 2, 1995.

47 Claus Kress, "Germany and International Criminal Law: Continuity or Change?," The Nuremberg Trials: International Criminal Law Since 1945, eds. Herbert R. Reginbogin, Christoph J. M. Safferling and Walter R. Hippel (Munich: Saur, 2006), 235-241.

48 See Werle, Völkerstrafrecht, MN 806-809.

49 Kress, "Germany and International Criminal Law". See also Werle Völkerstrafrecht, MN 28. 
then Secretary of State Joschka Fischer somehow silently revoked the reservation made to Article $7 \$ 2$ ECHR on Oct $5,2001 .^{50}$

\section{Closing Remarks}

Germany now shows a different attitude toward international criminal trials than before, and in discussions about a permanent ICC, the German government is playing a pro-active role. At the Rome conference for the establishment of the ICC, the German delegation was led by Hans-Peter Kaul, with Whitney Harris and Ben Ferencz as counsellors, both former prosecutors at Nuremberg - the prosecutors and the formerly accused nation working together to continue what was started at the Nuremberg Trials in order to prevent future crimes. What more could we wish for to keep the legacy of Justice Jackson alive?

The new government which came into power in Germany in 1998 under Chancellor Gerhard Schroeder and Secretary of State Joschka Fischer supported the struggle for international criminal justice, and Germany ratified the Rome Statute and passed a Code of International Crimes (Völkerstrafgesetzbuch [VStGB]), which can be seen as the most modern codification of substantive international criminal law and serves as a blueprint for many countries desiring to amend their national laws to fit the Rome Statute's requirement of complementarity. ${ }^{51}$ Hans-Peter Kaul was elected the first German judge at the ICC; later he was elected president of the pretrial chamber and as such administered the beginning of the first case of genocide in the situation of Dafur/Sudan at the ICC.

There is still a lot to be done. The German government is continuing to work on the ICC issue, and the Foreign Office includes a Working Commission on International Criminal Law consisting of practitioners-there

50 See Der 6. Bericht der Bundesregierung über ibre Menschenrechtspolitik in den auswärtigen Angelegenheiten und in anderen Politikbereichen (Human Rights Report), 2000/02, 36 [www.bmj.bund.de/media/archive/267.pdf]. The reservation was revoked about six months after the decision by the European Court on Human Rights (ECHR) in a case against the former SED party members Streletz, Kessler, Krenz v. Germany, March 22, 2001, Reports 2001-II, where the Court held that Article $7 \$ 2$ ECHR was inapplicable as the crimes committed by the accused were punishable even according to former GDR law, so that the principle of-non retroactivity was not violated.

51 See Christoph J. M. Safferling, "German Public Law Legislation - 2001/2002: Das Völkerstrafgesetzbuch," Annual of German and European Law 1 (2003), 365; an English text of the VStGB is reproduced ibid at 667. 
are many German lawyers working at the International Tribunals, with the international prosecutor, and at the ICC - and academics in international criminal law. ${ }^{52}$ Professor Albin Eser, the former director of the prestigious Max-Planck-Institute for Criminal Law and ad litem judge at the ICTY, admitted in Nuremberg in 2005 that in his work at the Tribunal he encounters the Nuremberg Trials on an everyday basis. ${ }^{53}$ A German judge using Nuremberg as a precedent — things have truly changed.

The sentiments of the German people concerning international justice can be summarized in the following way: Germans are totally certain and unified in their efforts towards achieving a properly working ICC with as many members and supporters as possible, because they have learned one thing: for state-supported atrocities, national courts are not well chosen to prosecute. There must be a complementary ICC ready to take over prosecution if the national system fails. This constitutes a warranted limitation to state sovereignty. ${ }^{54}$

There is one more thing that I have come to appreciate more and more during this very special year of remembrance: Nuremberg was not only the birth of international criminal law, it was also the beginning of democracy in Germany. The principles of human rights and the rule of law as the answer to cruelty provide a good basis for society. My idea of democracy is shaped by Justice Jackson and by what he expressed in his opening speech in courtroom 600 in the Palace of Justice in Nuremberg about the necessity to give every human being a fair and independent hearing: "For these defendants, however, we have set up an International Tribunal and have undertaken the burden of participating in a complicated effort to give them fair and dispassionate hearings. That is the best-known protection to any man with a defense worthy of being heard."

52 Since the drafting of this paper things have developed in different ways. Whereas the German judiciary has taken up old Nazi-cases and convicted several SSGuards at Concentrations Camps (see above note XX), the armed conflict in Syria forces German prosecutors to investigate international crimes committed during that conflict by either German nationals or refugees.

53 Eser, "Das Internationale Militärtribunal von Nürnberg".

54 See also Bruce Broomhall, International Justice \& the International Criminal Court (Oxford: Oxford University Press, 2003), 20-21; and Christoph J. M. Safferling, "Can Criminal Law be the Answer to Massive Human Rights Violations?," German Law Journal 5 (2004), 1469, 1472. 
The Appropriation by German Courts in French-occupied Baden of Control Council Law No. 10's Definition of Crimes against Humanity in the Prosecution of Nazi-era Defendants, 1946-1951

Michael S. Bryant

The story of the Allies' prosecution of Nazi war criminals after World War II has been exhaustively researched, generating scores of books, articles, and films that have documented the process whereby the Allies established the International Military Tribunal at Nuremberg to try top-ranking Nazi war criminals, while leaving to national courts scattered across Europe the responsibility for prosecuting German offenders in the countries in which they had perpetrated their crimes. A subject that has received less attention is the German judiciary's reconstitution as a partner with the Allies in prosecuting Nazi war criminals after the fall of the Nazi government in May 1945. In this essay, I will examine the history of the German judiciary's reconstitution as an instrument for punishing Nazi war criminals immediately after the war. We will trace the interweaving of German law and the law of the Allied Control Council, especially Control Council Law No. 10 (enacted in December 1945), in the jurisprudence of German courts in the French occupied zone of Baden. As we do, we will see that, despite formal restrictions on German jurisdiction, Law No. 10 empowered Baden courts to prosecute a broad spectrum of Nazi crimes as Crimes against Humanity until the early 1950 s.

Already before the German surrender, the Allies had drawn up plans to purge German society of National Socialist elements and prevent Germany from waging future wars. At the Yalta Conference in February 1945, they had decided to partition the country and its capital into four separate zones of occupation. In April, the U.S. Joint Chiefs of Staff pursued this policy of weakening postwar Germany by issuing JCS Directive 1067, a decree that reasserted the USA's intention to demilitarize, de-Nazify, de-centralize, and democratize the country. JCS 1067 also announced the closure of all German courts and the disbanding of all "extraordinary" and Nazi Party courts. Accordingly, after Germany's unconditional surrender in May 1945, the Allies suspended the operation of all German courts until the judiciary could be purged of National Socialist influences. At Potsdam 
in July 1945, the future shape of the German court system became clearer when the Allies declared it would be "reorganized in accordance with the principles of democracy, of justice under law, and of equal rights for all citizens without distinction of race, nationality, or religion." ${ }^{1}$

The Allies' plan was to reopen German courts once they had been scoured of former Nazi officials and "brown" ideology. After the Allied Control Council had repealed discriminatory legal measures adopted during the era of the Third Reich, ${ }^{2}$ it promulgated in late October 1945 Control Council Law No. 4 on the "Reorganization of the Judicial System," designed to create the basis for a uniform reconstitution of the German court system in each of the three western zones of occupation. Law No. 4 restored the system of ordinary courts as it existed prior to Hitler's appointment as chancellor, consisting of district (Amtsgerichte), state (Landgerichte), and appellate (Oberlandesgerichte) courts. ${ }^{3}$ Law No. 4 reasserted the traditional pre-1933 criminal jurisdiction of each of these courts: the district courts could impose prison terms up to five years; the state courts had jurisdiction over all cases beyond the competency of the district courts, and presided over appeals from the district courts on both factual and legal grounds; and the appellate courts reviewed appeals from the state courts but on legal grounds alone. Law No. 4, however, denied to the newly reestablished German courts jurisdiction over offenses committed by Germans against the allied occupation forces or citizens of allied nations and their property. It also deprived German courts of jurisdiction over crimes committed by allied soldiers or their nationals. ${ }^{4}$

1 Karl Loewenstein, "Reconstruction of the Administration of Justice in AmericanOccupied Germany," Harvard Law Review 61 (1948), 419-420; Henry Friedlander, "The Judiciary and Nazi Crimes in Postwar Germany," Simon Wiesenthal Center Annual 1 (1984), 27-28.

2 Control Council Law No. 1 (20 September 1945), cited in Friedlander, 28. As Loewenstein notes, both the Potsdam Declaration and JCS 1067 provided for the repeal of "peculiarly Nazi legislation." Loewenstein, 420. Control Council Law No. 1 reified the Allied intention to de-Nazify German law, announced as early as April 1945.

3 The Reichsgericht, the German Supreme Court before May 1945, was the fourth type of ordinary court in Germany. Dissolved with Germany's formal surrender in May 1945, it was succeeded by the Bundesgerichtshof when the Federal Republic of Germany came into existence in 1949.

4 Eli E. Nobleman, "The Administration of Justice in the United States Zone of Germany," Federal Bar Journal 8 (1946), 92-94; Loewenstein, 422-428; Michael S. Bryant, "Back into the Unmasterable Past: Southwest Germany and the Judicial Odyssey of Mayor Reinhard Boos, 1947-1949," Human Rights Review 8.3 (2007); 
Beyond the revival of the district, state, and appellate court system which had existed before 1933, Law No. 4 did not clarify precisely how the reorganization it contemplated should be effected; presumably, implementing the law's terms would be left to the discretion of the various Allied commanders in their zones of occupation. What was clear, however, was Law No. 4's denial of German jurisdiction over Nazi crimes, insofar as these were understood as targeting Allied citizens. ${ }^{5}$ The Allied Control Council modified its stance on this issue with the proclamation of Law No. 10 in December 1945. A primary purpose of Law No. 10 was to forge a uniform basis for national (or "zonal") trials, to be conducted by each of the four powers in its own zone of occupation. As Henry Friedlander has observed, the Allies intended to use Law No. 10 to prosecute Germans in Allied proceedings. ${ }^{6}$ For this reason, two of the three crimes that Law No. 10 promulgated-namely, "Crimes against Peace" and "War Crimes"were clearly outside the jurisdiction of German courts, inasmuch as these crimes involved acts of violence inflicted by Germans on non-German nationals. ${ }^{7}$ Regarding the $3^{\text {rd }}$ of the three offenses under Law No. 10, however, the Control Council left open the door to German jurisdiction. The third offense was "Crimes against Humanity," modeled to a large extent on the IMT Charter's definition set forth in Article 6 (c). Article II of CCL No. 10 defined Crimes against Humanity as follows:

Atrocities and offenses, including but not limited to murder, extermination, enslavement, deportation, imprisonment, torture, rape, or other inhumane acts committed against any civilian population, or perse-

Friedlander, 28; Adalbert Rückerl, The Investigation of Nazi Crimes 1945-1978 (Hamden, CT: Archon Books, 1980), 34.

5 See Article III of Control Council Law No. 4, excerpted in Rückerl, 33: “... jurisdiction of German courts shall extend to all cases both civil and criminal" except for "criminal offenses committed by Nazis or any other persons against citizens of Allied nations and their property, as well as attempts directed towards the reestablishment of the Nazi regime, and the activity of the Nazi organizations."

6 Friedlander, 31.

7 Two sources of law stymied German jurisdiction over Crimes against Peace and War Crimes: (1) the requirement under the Laws of Armed Conflict that jurisdiction over war crimes existed only where there was a diversity of nationality between defendant and victim; and (2) the prohibition in CCL No. 4, sustained in CCL No.10, which forbade German courts from presiding over Nazi crimes perpetrated on the soldiers and civilians of Allied countries. See CCL No. 10, section 1, paragraph (d), Appendix D to Telford Taylor, Final Report to the Secretary of the Army, CD-ROM (Seattle, WA: Aristarchus Knowledge Industries, 1995). 
cutions on political, racial, or religious grounds whether or not in violation of the domestic laws of the country where perpetrated.$^{8}$

Law No. 10 permitted each of the occupying powers to arrest individuals suspected of such crimes and to try them in "an appropriate tribunal." Further, the Law indicated that the occupying authority could entrust jurisdiction over Crimes against Humanity to a German court when both the perpetrators and the victims were German nationals or "stateless persons."

For the newly reestablished German judiciary after 1945, CCL No. 10 held two important implications. First, the Law's restriction meant that German courts were denied jurisdiction over the crimes of the Final Solution until German courts were forbidden by the Control Council to apply Law No. 10 after August 1951. Thereafter, they could only apply German criminal law in the trials of accused Nazi perpetrators. Second, the Law enabled the French, British, Americans, and Soviets to authorize German courts in their zones to try German defendants for Crimes against Humanity under CCL No. 10, so long as the victims were Germans or stateless persons. In fact, those German courts designated by the zonal authority as tribunals "appropriate" to try German defendants under CCL No. 10 had little choice but to prosecute these offenses as Crimes against Humanity. In some instances, such as where Law No. 10's definition of Crimes against Humanity did not fully embrace the elements of the alleged offense, the German court could charge a defendant with both a Crime against Humanity and an additional offense under German law. Consequently, in zones of occupation (like the French and British) in which German courts were required to charge their Nazi war criminals with Crimes against $\mathrm{Hu}-$ manity under Law No. 10, ${ }^{9}$ criminal indictments issued between 1946 and 1951 reflect a strange admixture of Control Council, international humanitarian, and German domestic law.

In charging Nazi defendants under CCL No. 10, German prosecutors enjoyed advantages denied them under German law. Unlike the provisions of the German penal code, Law No. 10 was based on the Anglo-American law of conspiracy, and thus did not recognize a distinction between perpetrators and accomplices: all participants in the crime were jointly liable as perpetrators for any acts carried out in furtherance of it. Another significant difference was Law No. 10's relative disregard of subjective factors in its deliberations on a defendant's guilt. Under Law No. 10, such issues as the defendant's consciousness of wrongdoing, developmental background,

8 Excerpted in Friedlander, 31.

9 See Rückerl, 40. 
or state of mind at the time of the offense, were immaterial. All that counted was that the defendant intentionally committed or helped commit an act condemned by Law No. 10, i.e., murder, extermination, enslavement, deportation, or political, racial, or religious persecution, all directed against "any civilian population." If the defendant was found to have committed any of these acts, regardless of the degree of his participation, he was guilty as a perpetrator of a Crime against Humanity. ${ }^{10}$ Other advantages that CCL No. 10 offered was a broader range of penalties than those prescribed in the German penal code: where the maximum punishment under German law (other than death and a life sentence) was capped at 15 years, CCL No. 10 enabled courts to impose sentences for any term of years, including life. Finally, courts could convict defendants under Law No. 10 for actions unrecognized as illegal under German law, such as "crimes of denunciation" (Denunziantenverbrechen), a species of wrongdoing that encompassed both persons who had denounced the Stauffenberg conspirators in July 1944 as well as the "grudge informers" who had turned in their neighbors to the authorities for listening to foreign radio broadcasts or disparaging Hitler. Crimes of denunciation also extended to German men whose acts of divorcing their Jewish wives had doomed them to deportation to the East. ${ }^{11}$

Control Council Laws No. 4 and No. 10 established the boundaries of justiciability of Nazi crimes in German courtrooms. Article II of CCL No.10, we will recall, had envisioned prosecuting as Crimes against $\mathrm{Hu}-$ manity two basic kinds of offense: crimes of the "murder type," which embraced homicide, extermination, enslavement, deportation, etc.; and those of the "persecution type," that is, crimes impelled by racial, political, or religious motives. Only in those cases in which these two kinds of offense involved German or stateless victims were German courts permitted to exercise jurisdiction. Furthermore, offenses committed by individual perpetrators acting alone were not Crimes against Humanity, insofar as the latter required "systematic mass action." As the UN War Crimes Commission

10 Michael S. Bryant, Confronting the "Good Death": Nazi Euthanasia on Trial, 19451953 (Boulder, CO: University Press of Colorado, 2005), 109-110; Jörg Friedrich, Die kalte Amnestie: NS-Täter in der Bundesrepublik (Munich: Piper Verlag, 1994), 152-153. See also the text of the Landgericht Tübingen's discussion of perpetration under CCL No.10 in Adelheid Rüter, C. F. Rüter, H. H. Fuchs and Irene SagelGrande, eds., Justiz und NS-Verbrechen: Sammlung deutscher Strafurteile wegen nationalsozialistischer Tötungsverbrechen 1945-1966 (Amsterdam: Amsterdam University Press, 1968-1981), Lfd. Nr. 155a.

11 Friedlander, 31-32. 
wrote in its comparison of definitions of Crimes against Humanity under CCL No.10 and the Tokyo Charter, "systematic mass action, particularly if it was authoritative, was necessary to transform a common crime, punishable only under municipal law, into a crime against humanity, which thus became also the concern of international law." ${ }^{12}$ As a practical matter, then, German courts in the immediate postwar era (1945-1951) prosecuted as Crimes against Humanity an assortment of "murder type" and "persecution type" offenses: the pogroms associated with the Night of Broken Glass in November 1938, denunciations by "grudge informers," killings of alleged "defeatists" at the end of the war, and political killings from the early years of the Nazi regime. What distinguished these offenses as Crimes against Humanity was the systematic mass action requirement: where this element was lacking, German courts typically charged their defendants solely with offenses under the German penal code. As far as the Nazis' excursions into mass extermination was concerned, CCL No. 10's prohibition of German jurisdiction over cases involving victims of Allied nations effectively removed the most sensational crimes of mass murder from German courts except one-the crimes of the Nazi "euthanasia" program. Euthanasia readily lent itself to German prosecution under Law No.10 because, first, the victims were in the main German nationals, and second, the murders were carried out pursuant to the orders of the Nazi government, thus satisfying the systematic mass action requirement. ${ }^{13}$

I would like to make our discussion a bit less abstract by examining how German courts appropriated CCL No. 10's definition of Crimes against Humanity in actual German trials after the war, until the Control Council forbade German prosecution under Law No. 10 in the fall of 1951. My focus will be on the trials of alleged Nazi offenders in French-occupied Baden in southwestern Germany, accused of participating in the Reich "Night of Broken Glass" pogrom in November 1938.

The allies assumed formal control of Baden on June 6, 1945, at which time much of the State was occupied by the French. What became known as the "French zone of occupation" was that portion of Baden south of the Karlsruhe-Stuttgart-Ulm autobahn, a zone that included the South Baden cities of Freiburg, Constance, Rastatt, Bühl, and Baden-Baden. In July 1945 the French military government relocated the State's ministries from Karl-

12 Excerpted in M. Cherif Bassiouni, Crimes against Humanity in International Law (The Hague: Kluwer, 1999), 36-37.

13 Friedlander, 32-33. 
sruhe to Freiburg, particularly the ministries of the interior, finance, and religious instruction. ${ }^{14}$

Like their British counterparts, the French military government required the German judiciary to charge Nazi offenders with Crimes against Humanity under CCL No. 10 when an alleged offense matched the elements set forth in Law No. 10's definition of the crime. In 1947, the French imposed a requirement on the Baden Ministry of Justice to deliver monthly reports on all cases involving alleged Crimes against Humanity that were being investigated or prosecuted by the Baden judiciary. The reports were to detail the following information: (1) the number of investigations pending at the beginning of the month for Crimes against Humanity, in which an indictment had not yet been issued; (2) the number of cases in which indictments for Crimes against Humanity had been issued, but which were not yet "legally final"; and (3) an index of new cases that had surfaced in which Crimes against Humanity were suspected. The reports had to be submitted no later than the sixth day of each month. ${ }^{15}$ The French later expanded this mandate to include information on proceedings against defendants that had become "legally final" (rechtskräftig abgeschlossen). The supplementary material was to include the names of the defendants, nature of the offense, date of verdict, and amount of punishment in the event the defendants were convicted. The French Military Government also demanded that the Germans inform them whether or not the accused was in preventive custody. ${ }^{16}$ The Baden Ministry of Justice in turn contacted the district attorneys offices throughout southern Baden, requesting that they compile the information demanded by the French authorities.

On January 26, 1948, the district attorney of Constance responded to the Ministry of Justice's request with a list of proceedings for Crimes against Humanity that were still pending before the criminal justice authorities of Constance. The district attorney's response reveals the diversity

14 Paul Ludwig Weinacht, "Die politische Nachkriegsentwicklung und die Auseinandersetzungen um den Südweststaat," Badische Geschichte: Vom Großherzogtum bis zur Gegenwart, ed. Landeszentrale für politische Bildung Baden-Württemberg (Stuttgart: Konrad Theiss Verlag GmbH, 1987), 212-213.

15 Letter of the Baden Ministry of Justice to the Senior Public Prosecutor of Constance, dated November 7, 1947, concerning criminal proceedings for Crimes against Humanity, Staatsarchiv Freiburg [hereafter SF], F 178/1, No. 111.

16 Letter of the Baden Ministry of Justice to the Senior Public Prosecutor of Constance, dated January 23, 1948, concerning criminal proceedings for Crimes against Humanity, SF, F 178/1, No. 1109. 
of Nazi-era offenses investigated or tried in Baden after the war. They included cases involving the destruction of synagogues; denunciations; mistreatment of political opponents; mistreatment of Jews; collaboration in illegal sterilizations; shooting of political prisoners; discrimination against a woman for sexual intercourse with a Polish POW; abuses committed in concentration camps; and causing another person to be interned in a labor camp. The majority of suspected perpetrators in these cases had not yet been prosecuted, and many remained at large as of the date of the report. In addition to this list of pending cases, the district attorney of Constance submitted an index of legally final proceedings against defendants charged with Crimes against Humanity in the state court of Constance. The earliest case ended on February 2, 1947, involving three defendants charged with abusing preventive detainees in a concentration camp. Two of the three were convicted and sentenced to prison terms of 10 and 4 months, while the third was acquitted. ${ }^{17}$

A memorandum from the prosecutor general (Generalstaatsanwalt) in Freiburg, dated 7 December 1948, to the district attorney of Constance, discloses how Baden prosecutors interpreted Law No. 10's definition of Crimes against Humanity as it applied to Nazi-era offenses. In an earlier letter, the Constance DA had asked the prosecutor general whether the DA could prosecute denunciation cases as Crimes against Humanity, or whether instead these offenses should be processed in denazification proceedings (Spruchkammer). The prosecutor general replied with an extended excerpt of an advisory opinion authored by the Baden Ministry of Justice, which, in view of its acceptance by the French Military Government, was considered authoritative on the issue of how denunciations should be processed in Baden courts. In this excerpt, the Baden Ministry of Justice distinguished between two categories of denunciation, each of which was shaped by the unfolding radicality of the National Socialist police state. The first type of denunciation occurred between the Nazis' seizure of power in 1933 and the outbreak of war in September 1939. These cases were tried in Sondergerichte (special courts) on the basis of two Nazi penal statutes: $₫ 3$ of the Reich President's Decree for Protection against Treacherous Attacks on the Government of March 21, 1933; and $\mathbb{S} 1$ and 2 of the Treachery Law (Heimtückegesetz) of December 20, 1934. The Justice Ministry observed that the Nazi special courts meted out comparatively mild punishments for violations of these laws, consisting for most offenders of

17 Verzeichnis der schwebenden Verfahren wegen Verbrechens gegen die Menschlichkeit, SF, F 178/1, No. 1109 ff. 
short jail terms. Confinement in a concentration camp after serving the prison sentence typically did not ensue. In some instances, however-such as cases where the victims of denunciation were "politically prominent personalities" and Jews, for example-internment in a concentration camp after completion of sentence was customary. In such cases, the Ministry of Justice opined that the element of "other inhumane acts" (unmenschliches Handeln) under CCL No. 10, II 1(c), was satisfied both objectively and subjectively. On the objective level, the "inhumanity" of the deed met the statutory elements set forth in Law No. 10. On the subjective level, the Justice Ministry pointed out that the denouncer must have recognized that "the person being reported would be subjected to a proceeding that had little to do with justice, but served rather to eliminate ruthlessly all dissident thought." Hence, the state attorneys could indict these defendants for committing a Crime against Humanity under CCL No. $10 .{ }^{18}$

Aside from the foregoing exception, the Justice Ministry indicated in the excerpted language that most of the cases of denunciation prior to September 1939 were to be processed in Baden denazification hearings. The Ministry distinguished the prewar category of denunciations, however, from those occurring after the onset of the war. After September 1939, said the Ministry, the special courts began punishing the objects of denunciation severely. The legal basis of the more draconian measures was a "special military criminal decree," which, although promulgated on August 8,1938 , did not become operative until August $26,1939 . \$ 5$ of the decree contained a clause that made "undermining military power" (Zersetzung der Webrkraft) punishable by death or, in milder cases, imprisonment. This offense applied to anyone who "publicly sought to impair or undermine the will of the German or allied peoples to able-bodied self-assertion." The Nazi authorities induced district attorneys and courts to indict persons accused of making derogatory remarks about Hitler and critical remarks about the conduct or outcome of the war. The defendants would no longer be tried under the "treachery law" of December 1934, but on the basis of the "special military criminal decree" and its prohibition of actions that "undermined military power." Henceforth, in all cases tried under the special military decree, the convicted person was typically taken into cus-

18 Memorandum of the prosecutor general in Freiburg to the district attorney of Constance regarding Crimes against Humanity, dated November 29, 1948, SF, F 178,1 , No. $111,1-3$. 
tody by the Gestapo after completion of the prison term, and thereafter interned in a concentration camp. ${ }^{19}$

According to the Justice Ministry, the decisive turning point in these "inhumane proceedings" occurred sometime in 1941. From this time forward, the growing number of convictions under the special military decree reflected a rigor of punishment lacking in the prosecution of similar offenses between 1933 and 1940. The kinds of offenses punished with a jail term of a few months in the earlier period now resulted in lengthy prison terms and frequently the death penalty, particularly after the military defeat at Stalingrad in 1943. In the words of the Justice Ministry, "anyone accusing others of insulting or defeatist statements from 1941 onward had to be aware that the person accused would suffer thoroughly inhumane treatment [by the authorities]." 20

In order to distinguish these two species of denunciation, the Justice Ministry cited the 1933 case of a man named Reupold, denounced to the authorities on the basis of $₫ 3$ of the Reich President's Decree. The special court sitting in Mannheim convicted Reupold and sentenced him to a four-month jail term. After a couple months, he received probation for good behavior and was released from jail. In this case, the Justice Ministry reasoned, there was no question that the man who had reported Reupold to the authorities had in fact done so, or that he was deserving of punishment for his misdeed. This notwithstanding, the Justice Ministry doubted that such a denunciation could be regarded as a "Crime against Humanity." Presumably, the relative mildness of Reupold's punishment did not fulfill the element of "inhumane action" under Law No. 10. The Ministry's doubts received further confirmation from a State decree published in March 1947, which stated that denouncers who harmed others by reporting their political opposition to the Nazi authorities could be characterized as "activists" by the denazification courts. The denazification courts could then punish the denouncer with imprisonment or confiscation of property. Processing cases like Reupold's in denazification proceedings was, finally, preferable to a criminal trial because of the risk that the denouncer could be acquitted. After excerpting the advisory opinion of the Justice Ministry, the prosecutor general's memorandum recommended that in such cases the state court enter a dismissal order, to which the judge should attach his reasons for dismissing the case. ${ }^{21}$

19 Ibid., 3-4.

20 Ibid., 4.

21 Ibid., 5-6. 
The views of the Ministry of Justice show that Baden courts were expected to prosecute Nazi-era crimes as Crimes against Humanity when they met the element of "inhumane conduct" under CCL No. 10. Whether or not a defendant's actions fulfilled the element of "inhumaneness" under Law No. 10 was, however, by no means the only consideration of Baden courts in prosecuting Crimes against Humanity against German defendants. In responding to the legal arguments of defendants accused of participation in the nationwide pogrom of November 10, 1938, southwest German courts expounded additional juridical theories that governed when Crimes against Humanity would be charged against Nazi defendants.

The indictments in the Baden trials of the November 1938 pogrom defendants are notable for their amalgam of national and international law. ${ }^{22}$ Depending on the facts of the case, defendants were usually accused of (1) a Crime against Humanity under CCL No.10, insofar as evidence suggested the defendant's actions stemmed from political or racial motives; (2) Breach of the Public Peace (Landfriedensbruch), for disrupting public order; and (3) breaking and entering (Hausfriedensbruch), when the defendant forcibly entered a synagogue or Jewish dwelling, typically for the purposes of vandalizing, plundering, or setting it on fire. These three fundamental charges were sometimes joined to additional offenses, such as "incitement to class struggle" (Anreizung zum Klassenkampf), "destruction of property" (gemeinschädliche Sachbeschädigung), or "false imprisonment" (Freiheitsberaubung). All of these charges except Crimes against Humanity were considered violations of the German penal code as it existed at the time of the offense- that is, the Baden courts insisted that the criminal law remained operative during the reign of the Nazi Party, and in spite of the Nazis' endorsement of the pogrom.

In the Sulzburg synagogue case (tried in December 1947), the defendants were charged with crimes against the male Jewish citizens of the town, whom Gestapo officials ordered assembled on November 10, 1938, and marched on foot to the prison in nearby Müllheim. As Sulzburg's Jewish men marched off to prison, the synagogue, the Jewish school, and nearly all of the Jewish houses and businesses were vandalized and plundered. One of the defendants implicated in the destruction of Jewish property

22 Although Crimes against Humanity under Law No. 10 were technically "national" law (because the Allied Control Council was the sovereign lawmaking authority in Germany), the definition was based on the London Charter, which was international law. Due to its roots in international humanitarian law, then, a Crime against Humanity under Law No. 10 was arguably premised on international law. 
was a man named Köhler. The Landgericht Freiburg convicted him of a Crime against Humanity because his offense-breaking out the windows of a Jewish confection store with a walking stick-was politically and racially motivated, thus fulfilling the elements under CCL No. 10. By contrast, in assessing the guilt of a co-defendant named Pfister, who lived in a neighboring town and drove to Sulzburg on the morning of the pogrom, the court acquitted him of a Crime against Humanity because it was unconvinced that he had joined the Sulzburg mob for racial or political reasons; rather, the court thought it more likely that his presence at the scene of the pogrom was actuated by curiosity and obedience to the orders of his superior to drive to Sulzburg that morning. ${ }^{23}$

The trial of 16 defendants accused of participating in the November pogrom in the Baden city of Offenburg provides further insight into the Baden judiciary's appropriation of Crimes against Humanity in German courtrooms. The Offenburg pogrom involved the destruction of the synagogue and its contents, the arrest and jailing of Offenburg Jews before their transportation to the Dachau concentration camp, and the vandalization of a Jewish café by an anti-Jewish mob. For their alleged roles in one or more of these stages of the pogrom, the defendants were charged with various permutations of Crimes against Humanity, aggravated breach of public order, aggravated breaking and entering, incitement to class struggle, destruction of property, and false imprisonment. In its discussion of the law applicable to defendants' offenses, the state court of Offenburg noted that German courts after 1945 had augmented CCL No. 10's definition of Crimes against Humanity to include "every act of cruelty against human existence as well as every act that degraded human worth and destroyed human culture, insofar as they were committed under the influence of a political will to power and of a dominant idea pursued by it." The state court went on to quote the jurist Güde, who had glossed Law No. 10's reference to racially, politically, or religiously motivated persecution as follows: "Violation of human rights through terroristic abuse of state or political power, inflicted on political, religious, or racial enemies." 24

23 Strafsache gegen den Metzger Alfred Spath aus Laufen u.a., SF, 176/22, No. 5/1/172 ff. Acquitted of Crimes against Humanity and of plundering, Pfister was convicted of breach of the public peace.

24 Urteil in Strafsache gegen Oskar Wiegert u.a., SF, F 176/4, No. 19/22/060 (quoting OLG Köln in Neue Juristische Wochenschrift 2 (1947), 70; and Güde, Deutsche Rechtszeitschrift (1947), 111). 
The Offenburg state court had little trouble classifying the pogrom as a Crime against Humanity, insofar as it was driven by racial and religious hatred toward the Jews. Moreover, the court stressed that the pogrom was not a purely "local" action of disaffected fanatics, but rather a "planned operation against the Jews carried on throughout Germany," orchestrated by the highest levels of the Nazi government. The court emphasized that the pogrom had to be comprehended in its totality as a phenomenon instigated and guided by an anti-Semitic political system; individual charges of disturbing the peace, false arrest, etc., should not, the court cautioned, be allowed to obscure the essential unity of the crime. Further, the court insisted that the illegality of the pogrom was clearly recognizable to all the defendants. No "mistake of law" (Verbotsirrtum) would shield them from their contributions to the assault on Offenburg's Jews. ${ }^{25}$

It was, of course, in the defendants' interest to preempt application of Law No. 10's Crimes against Humanity to their actions, chiefly because Law No. 10 prescribed a higher range of punishment than did German law, and because No. 10 discounted subjective factors in assessing an actor's liability under the statute. If the Offenburg pogrom defendants expected the court to dismiss the Crimes against Humanity charge, they were disappointed. Citing the famed jurist Gustav Radbruch, the state court held that CCL No. 10, as a decree of the "highest legislative authority" in Germany, was binding law alongside the German penal code. Accordingly, the court announced its intention to construe the acts of the defendant in connection with the pogrom as a "unified course of action," as required by Law No. 10. This meant, in effect, that the court would not divide the pogrom into individual crimes performed by autonomous actors, but would consider the pogrom as a unitary and continuous crime involving the defendants' myriad contributions. ${ }^{26}$ The court furthermore refused to suspend application of Crimes against Humanity based on the objection of

25 Ibid., 19/22/060-062.

26 Ibid., 19/22/062. German law distinguishes between "ideal" and "real" concurrence in instances of collective criminality. Ideal concurrence portrays all actors involved in the criminal enterprise as being liable for acts carried out in furtherance of it, not just for their own individual contributions. Real concurrence, by contrast, foregrounds the individual contributions of the actors within the general scheme. Inasmuch as German courts interpreted CCL No.10 as requiring the doctrine of ideal concurrence, Law No. 10 bears comparison with the vicarious criminal liability imposed by the law of conspiracy, which formed the backbone of the Allies' case against the major war criminals at Nuremberg. On the distinction between the two forms of concurrence, see Devin O Pendas, The Frankfurt Auschwitz Trial, 1963-1965: Genocide, History, and the Limits of the Law (Cam- 
retroactive prosecution: in the court's view, to nullify Law No. 10's application to Nazi crimes based on the historic prohibition of retroactive legislation in German law would evacuate Law No. 10 of "any practical meaning." The court noted that in any event Anglo-Saxon common law did not unconditionally forbid retroactive laws. ${ }^{27}$

In none of the pogrom trials prosecuted in French-occupied Baden did the accused's defense prevail when based on arguments of CCL No. 10's retroactivity. When a defense to a charge under Law No. 10 succeeded, it was usually because the court found the evidence of criminal wrongdoing insufficient, either because witnesses recanted their earlier statements or the defendant's actions did not fulfill the elements of a Crime against $\mathrm{Hu}-$ manity. In a subsequent trial involving a second group of alleged participants in the Offenburg pogrom, all five of the defendants were acquitted of Crimes against Humanity, breach of public peace, and false imprisonment for their roles in arresting Offenburg Jews and escorting them to the train station, whence they were transferred to Dachau. During trial the witnesses against the defendants recanted their incriminating testimony, leaving the defendants' own narratives of the events unrefuted. According to their version, the accused did not arrest and escort the Jews for motives of racial or religious hatred, but in order to protect the Jews from a mob enraged over the assassination of the German diplomat, Ernst vom Rath. In the absence of proof that they had acted from invidious motives, the court acquitted the five defendants of Crimes against Humanity. ${ }^{28}$

German prosecution of Nazi defendants for Crimes against Humanity would continue until September 1951, when the Allies, at the urging of the Germans, prohibited German courts from applying CCL No. 10. At this time, the British and French revoked the authorization under CCL No. 10, Art. III, No. 10, which had enabled the Germans to charge defendants with Crimes against Humanity. From that time forward, West Ger-

bridge: Cambridge University Press, 2006), 197; Fritz Bauer, "Ideal- oder Realkonkurrenz bei nationalsozialistischen Verbrechen?”, Juristenzeitung 22 (1967), 627.

27 Urteil in Strafsache gegen Oskar Wiegert u.a., SF, F 176/4, No. 19/22/062.

28 Urteil in Strafsache gegen Hans Jockers u.a., SF, F 179/6, P.3, No. 12. The Offenburg court also acquitted the defendants of breach of public peace and false imprisonment on the theory that the SS became auxiliaries to local police forces on November 10 for the purpose of maintaining order. Because the defendants participated in an apparently legitimate police function in taking into custody and escorting the Jews, they had a reasonable belief that their actions were legal. 
man courts would apply only German domestic criminal law in the trials of accused Nazi war criminals. ${ }^{29}$

\section{Conclusion}

As we have seen, charging Nazi offenders with Crimes against Humanity under CCL No. 10 held several advantages for prosecutors. Not only did Law No. 10 afford prosecutors greater flexibility in charging defendants and securing more severe punishment than German domestic law did, but it rejected German law's distinction between perpetrators and accomplices. This meant that all participants in the crime were jointly liable as perpetrators for the acts of their confederates that furthered the criminal scheme, just as they would be on a theory of conspiracy.

None of this is surprising if we consider that CCL No. 10 was based on the doctrine of conspiracy. When the Germans applied and interpreted Law No. 10's definition of Crimes against Humanity in their own courtrooms, they construed it as requiring a focus on the defendants' vicarious liability for the crimes of their co-conspirators in the officially sanctioned criminal enterprise. In the language of German law, German courts endorsed a theory of "ideal concurrence" to evaluate the criminality of their defendants' acts. Learned Hand once commented that the crime of conspiracy was "the darling of the modern prosecutor's nursery," because it enabled prosecutors to hold defendants criminally liable for the actions of their co-actors. ${ }^{30}$ Built on the doctrine of conspiracy, Law No. 10 and its appropriation in German courts was no less a "darling" to the Baden judiciary in the immediate postwar era.

The tide turned decisively in favor of Nazi defendants, however, when the Allied Control Council prohibited German courts from charging them under Law No. 10 after August 1951. Henceforth, the crimes of Nazi offenders would be adjudicated in West German courts under German criminal law, not the more stringent law of the Allied Control Council. Although applying domestic law enabled German courts to avoid the ex post facto challenge frequently heard in trials based on Law No. 10, German criminal law was a boon to many Nazi defendants. First, in contrast with

29 Memorandum from the Baden Justice Ministry to the District Attorney of Constance, December 6, 1951, regarding criminal proceedings under CCL No. 10, SF, F 178/1, No. 1112; excerpt from the Baden Ministerial Journal December 28 (1951), No. 25, SF, F 178/1, No. 1112. See also H. Friedlander, 32; Rückerl, 40.

30 Harrison v. United States, 7 F.259 (2d Cir. 1925). 
Law No. 10, German law distinguished between perpetrators and accomplices based on the subjective disposition of the actor. Such an approach did not impute liability based on the acts of a defendant's confederates, as Law No. 10 had done, but purely with regard to the offender's individual actions and psychological disposition. Second, German courts in their trials of Nazi crimes adopted the approach of "real concurrence," that is, they focused on the defendant's real actions in isolation from the context in which these acts were committed. The emphasis on subjectivity and the adoption of real concurrence in assessing the individual acts of offenders clearly benefited accused war criminals. When these post-1951 developments are considered along with the expiration of statutes of limitations governing Nazi-era crimes in 1955 and again in 1960, we can appreciate why Nazi war crimes trials subsided so dramatically between 1951 and the late 1950s. Without question, German political and international geopolitical events contributed to this precipitous dropoff, as did the German judiciary's own ambivalence toward prosecuting Nazi crimes. In studying the German confrontation with Nazi criminality in the postwar years, however, the limitations of German domestic law should be given their proper due. 


\section{"Violation of Human Dignity" and Other Crimes Against Humanity in Austrian War Crimes Trials}

Winfried R. Garscha

The Austrian approach to the punishment of Nazi crimes shows some ways that are distinct from Allied and German regulations. ${ }^{1}$ In prosecuting many crimes as a form of high treason, Austria was more similar to liberated countries such as Czechoslovakia and France than to Germany. And Austria prosecuted crimes against humanity as "violations of human dignity".

Like occupied Germany, Austria also had Allied courts. But unlike Germany there was no Allied legislation to be observed by Austrian courts. The four occupying powers allowed the Austrian courts criminal jurisdiction against both Austrian and non-Austrian nationals on the basis of Austrian laws. And whereas Allied courts in Austria almost exclusively tried war crimes committed against Allied nationals and violations of post-1945 regulations in their respective occupation zones, Austrian courts were allowed to try the whole variety of Nazi crimes, including crimes against $\mathrm{Al}$ lied soldiers and POWs. This reflects the position of postwar Austria in international politics as a liberated and occupied country; it was regarded, by the Allies as both Hitler's first victim and part and parcel of Nazi Germany.

Just two weeks after the liberation of Vienna by Soviet troops in early April 1945, a provisional Austrian government was formed by conservatives, social democrats and communists. One of the first legal acts of this government, the Nazi Banning Act of May 8, 1945, ordered the dissolution of the Nazi party and interdicted any revival of this party or propaganda

1 For a survey of the Austrian postwar trials cf. my articles "The Trials of Nazi War Criminals in Austria," Nazi Crimes and the Law, eds. Henry Friendlander and Nathan Stoltzfus, Publications of the German Historical Institute (Cambridge, UK: Cambridge University Press, 2008), 139-150, and "Austrians and the Holocaust: A Reception History from the Perspective of Postwar Volksgerichtsprozesse," New Perspectives on Austria(ns) and World War II, eds. Günter Bischof, Fritz Plasser, and Babara Stelzl-Marx, Contemporary Austrian Studies 17 (London: Transaction Publishers, 2009), 277-305. 
for it. ${ }^{2}$ One section of the Nazi Banning Act retroactively declared "acts committed with heinous intent ["verwerfliche Gesinnung"], particularly despicable acts ["besonders schimpfliche Handlungen"], and acts "grossly contradicting the laws of humanity" to be punishable offenses. ${ }^{3}$ The law of May 8, 1945, did not define what kind of breaches of the so-called laws of humanity were to be prosecuted apart from the fact that terms like "heinous intent" and "particularly despicable" indicated that the law-makers intended to provide a legal framework for the prosecution of those perpetrators who had degraded their victims.

It is interesting to note the use of the term "heinous intent" and not "base motives" ("niedrige Beweggründe"), which would have been more familiar to judges and prosecutors since it had been in the German penal code since 1941 describing the elements of the crime murder. ${ }^{4}$ Of course this had something to do with the politics of the new Austrian government, which was anxious to separate Austria as clearly as possible from Germany. ${ }^{5}$ But the different wording also reflected a different understanding of the character of the crime and of the criminal offender. Whereas the so-called "base motives" applies to the perpetrator's inducement to commit the crime, the term "heinous intent" characterizes the perpetrator as a person with racist or similar political or ideological attitudes.

The law also refers to The Hague Convention of 1899 in using the vague term "laws of humanity". Obviously, the Austrian provisional government hoped to evade the problem of retroactivity. And what kind of breaches of those "laws of humanity" were to be prosecuted? The so-called Nazi Criminals Act, a law promulgated by the provisional government on June 26, 1945, defined the scope of Nazi crimes that were to be brought before the

2 This regulation is still in force and even overrules the constitutional right of freedom of speech. It has been used as legal clause for punishing Holocaust denial. The most prominent non-Austrian defendant was the British historian David Irving, who was sentenced by a Viennese court on February 20, 2006 to three years of imprisonment.

3 "Verfassungsgesetz vom 8. Mai 1945 über das Verbot der NSDAP" ("Verbotsgesetz"), $\mathbb{1 1}$ (Staatsgesetzblatt für die Republik Österreich 13/1945). The texts of all postwar anti-Nazi laws are accessible via internet on the website of the Austrian Research Agency for Postwar Justice, http://www.nachkriegsjustiz.at/service/gesetze.

4 After the Anschluss, in March 1938, most Austrian laws, including almost all sections of the traditional penal code, had remained in force in the Austrian provinces. On September 24, 1941, the Nazis replaced the sections of the Austrian penal code concerning murder and manslaughter with the (new) German clauses.

5 Cf. Steven Beller, A Concise History of Austria (Cambridge, UK: Cambridge University Press 2006), 250, 255 sqq. 
new People's Courts, which had special jurisdiction over them. ${ }^{6}$ The first eight sections of the War Criminals Act enlisted those crimes as follows:

$\$ 1$. Nazi war crimes (against either against enemy nationals or the civilian population of any country, including Austrians);

$\$ 2$. Inciting people to war (a clause which was directed both against Nazi propagandists and those who tried to prevent people from surrendering to the Allied troops in the last weeks of the war);

$\$ 3$. Torture (defined as setting a person into a painful or terrifying situation), assault, and battery (defined as inflicting severe harm on a person),

$\$ 4$. Violations of humanity and of human dignity;

$\$ 5$. Deportation (or, as the law put it, "expropriation, resettlement, or expulsion from the home country");

$\$ 6$. Abusive enrichment (such as the seizing of Jewish property, or "Aryanization");

$\$ 7$. Denunciation out of reprehensible motives (note that the chosen word is "motives" and not "attitudes");

$\$ 8$. High treason against the Austrian people.

With the exception of high treason and incitement to war, all those crimes can be considered as crimes against humanity, and $\mathbb{S} 3$ and 4 define what was understood as a Nazi crime: one which was "committed during the time of Nazi tyranny in the actual or assumed interest of that tyranny, if the perpetrator acted out of political hatred or in taking advantage of official or other forms of power". ${ }^{7}$ Both the Nazi Banning Act and the War Criminals Act contained regulations concerning high treason in the form of clandestine support of the Austrian Nazi movement before the annexation of the country by Nazi Germany in 1938, but the definition of crimes against humanity was linked specifically with the Nazi rule, i.e. in Austria the period from March 13, 1938, until the liberation in April/early May 1945 .

6 Until the parliamentary election on November 25, 1945, the provisional government acted as both executive and legislature. Its laws, applicable in the first months after the liberation only in the Soviet occupation zone, were adopted, though, by a meeting of representatives from each Austrian province, including those occupied by the Western Allies, in September 1945. After the democratic elections, these laws were approved and amended by the parliament.

7 "Verfassungsgesetz vom 26. Juni 1945 über Kriegsverbrecher und andere nationalsozialistische Untaten" ("Kriegsverbrechergesetz"), $\mathbb{S} \mathbb{} 3$ and 4 (Staatsgesetzblatt für die Republik Österreich 32/1945). 
The War Criminals Act targeted single or continuously perpetrated criminal offenses committed by individuals who had been either members of the Nazi party or profiteers during the Nazi rule, but $\$ 1$, which defined Nazi war crimes, and $\$ 3$, which defined torture, assault, and battery targeted whole groups of perpetrators and assigned them criminal responsibility without proof of their individual guilt. The former concerned all those who were regarded as "originators and ringleaders" of the crimes defined as Nazi war crimes, namely members of the Nazi Reich government, the governors of the Austrian provinces during the Nazi period (Gauleiter) and members of the Nazi elite equal to them in rank (like members of the Reich government), and SS-leaders down to and including colonels. All those should receive the death penalty. ${ }^{8}$

The reason for the threat of such severe punishment also for the province leaders of the Nazi party was the fact that those party leaders had been installed by Hitler in 1943 as so-called "Reich defense commissars" in their respective provinces, and by that position, had been responsible for many of the most appalling crimes committed in the last days and weeks of the Nazi regime. In addition, $\mathbb{3}$ assumed that all staff members of concentration camps and all Gestapo officers had either maltreated individual prisoners or been responsible for torture and other violations of human dignity. Judges and prosecutors of the so-called Nazi People's Court (Volksgerichtshof) were put into that category, because the People's Court had been an important instrument for Nazi persecution in imposing severe punishments, including many death penalties, on people who opposed the Nazi dictatorship. Many of the defendants had been tortured before they stood trial, and after they got the death penalty, many of them had to wait for a long time before they were executed, because the court wanted them to witness against other defendants. Judges and prosecutors of the People's court were automatically assumed to be accomplices to that crime.

This was the law. But the legal reality was quite different. After two decades of thorough examination of the court records of Austrian postwar court records, the Research Agency for Postwar Justice did not find a single case where a defendant was sentenced only because of his membership to one of the administrative bodies described above. All of them had been accused of concrete criminal acts. And only one of them received the death sentence-a high ranked Gestapo officer in the province of Styria who had personally supervised abdominable tortures of resistance fighters. Whereas the attribution of crimes against humanity to certain categories of defen-

8 “Kriegsverbrechergesetz," \$1 (6). 
dants without examination of individual guilt did not work, there were more or less formal counts in many indictments, but they did not concern crimes against humanity, but high treason.

In that respect the Austrian People's courts resembled the special denazification courts in the British occupation zone of Germany, the so-called Spruchgerichte, which conducted criminal proceedings for membership in criminal organizations like the leadership corps of the Nazi party, the Gestapo or the SS. ${ }^{9}$ According to the Austrian Nazi Banning Act of May 8, 1945, every person recognized after the Nazis came to power in 1938 as a member of the clandestine Austrian Nazi party in preceding years had to face a charge of high treason, and it came to more than 100,000 people. Legal proceedings were instituted against most of them after the war. Some 25,000 were indicted and $50 \%$ of those convicted, most of them either because they had committed other crimes or because they had held leadership positions in the Nazi party. ${ }^{10}$

In the ten years between 1945 and 1955, the special courts for the punishment of Nazi crimes, the so-called Austrian People's Courts, imposed 13,000 sentences and 10,000 acquittals. Out of the 13,000 convictions, almost 8,000 were based on "formal" reasons, mostly that the defendants had been members of the clandestine Nazi party before 1938 or had held positions in the party hierarchy, which was accounted high treason. Among the more than 5,000 defendants who were found guilty for crimes against humanity, approximately 3,000 were sentenced for the crime of denunciation $(3,000$ more were indicted for the same crime but were acquitted). ${ }^{11}$

9 Ian D. Turner, Reconstruction in Post-War Germany: British Occupation Policy and the Western Zones, 1945-1955 (Oxford: Berg Publishers, 2007), 239-267.

10 For the official statistics cf. Karl Marschall, Volksgerichtsbarkeit und Verfolgung von nationalsozialistischen Gewaltverbrechen in Österreich. Eine Dokumentation, 2nd ed. (Vienna: Justizministerium, 1987). In English, see Winfried R. Garscha and Claudia Kuretsidis-Haider, "Justice and Nazi Crimes in Austria, 1945-1955: Between Self-purge and Allied Control," Bulletin du comité international d'histoire de la deuxième guerre mondiale 27/28 (1995), 245-255; Marschall's figures are reproduced on pp. 250-251. An internet version of Marschall's figures as well as current updates are available on theweb site of the Austrian Research Agency for Postwar Justice, http://www.nachkriegsjustiz.at/prozesse/volksg/index.php.

11 Heimo Halbrainer, "Der Angeber musste vorhersehen, dass die Denunziation eine Gefahr für das Leben des Betroffenen nach sich ziehen werde": Volksgerichtsverfahren wegen Denunziation mit Todesfolge in Österreich," Holocaust und NS-Kriegsverbrechen vor Gericht: Der Fall Österreich, eds. Thomas Albrich, Winfried R. Garscha, and Martin F. Polaschek (Innsbruck: Studien Verlag, 2006), 229-261. The article deals with cases in which the denunciation had caused the 
The Austrian War Criminals Act declared denunciation a criminal offense, if the perpetrator intentionally had inflicted harm on a person by denouncing him or her to the Nazi authorities. The sentence was to be upgraded if some preconditions were fulfilled, e.g., if the information given to the Nazi authorities was knowingly wrong, or if the informer acted out of selfish motives ("eigennützige Beweggründe"). If the informer should have been able to foresee that the denunciation would endanger the life of the denounced person, and if the denounced person actually received the death penalty (or was murdered in a concentration camp), the sentence for the informer was life imprisonment. Three hundred fifty defendants had to stand trial for a denunciation that had caused the death of the denounced person (around $50 \%$ of all defendants in homicide cases tried by the People's courts), 187 out of those 350 defendants were found guilty; 40 received sentences of more than 5 years, among them three life imprisonments.

In Germany denunciation could not be prosecuted according to German law, but rather according to Control Council Law No. 10, which, however did not mention the crime explicitly, counting it among the "other inhumane acts" mentioned in article 2-1-c of the law. An explicit legal basis was finally provided by Directive 38 of October 12, 1946, in which the Allied Control Council for Germany regulated the "arrest and punishment of war criminals, Nazis, and militarists, and the internment, control, and surveillance of potentially dangerous Germans." ${ }^{12}$ The actual goal of this directive was to establish a framework for the denazification of German society by establishing five categories of subject ranging from "major offenders" to "persons exonerated". Among the second group, called "activists, militarists, and profiteers," the directive included as "activists ... anyone who, as a provocateur, agent, or informer, caused or attempted to cause, institution of a proceeding to the detriment of others because of their race or religion or political opposition to national socialism or because of violation of national socialist rules." In East Germany "denuncia-

death of the denounced person. On p. 230 Halbrainer presents a table of all denunciation cases.

12 Quoted according to the internet publication of the documents by the German Historical Institute Washington DC, http://germanhistorydocs.ghi-dc.org/pdf/eng /Denazification\%203ENG.pdf, which is based on John J. McCloy, "Present Status of Denazification," Office of the U.S. High Commissioner for Germany, 5th Quarterly Report on Germany October 1-December 31, 1950, 46-55 (accessed December 2019). 
tion" trials were not unknown, but they played a less important role than in Austria; in West Germany such trials were extremely rare. ${ }^{13}$

The most important category of crimes against humanity to be tried by postwar courts in both Austria and Germany were those committed in the last weeks of Nazi rule which the Dutch law professor Christiaan Frederik Rüter calls the "final phase crimes." Rüter has been leading a huge documentation project on Nazi crimes trials since $1965 .{ }^{14}$ German prosecutors charged perpetrators who had taken part in such crimes with murder or manslaughter according to the German penal code, and as the hundreds of judgments published by Rüter show, "final phase crimes" accounted for a large part of the sentences imposed by district courts in all four occupation zones.

For the prosecution of those crimes it was of special importance that, as already mentioned, the Austrian War Criminals Act defined war crimes in a manner unique in international law at that time and included crimes against the civilian population of the home country. Of course, this was not in anticipation of the second additional protocol to the Red Cross Conventions passed in $1977^{15}$, but was intended to avoid impunity for crimes committed by armed forces of the Nazi state in cases where the victims were not enemy nationals. The Act distinguished two kinds of Nazi

13 Cf. the comparative table by Heimo Halbrainer, "Das Verbrechen der Denunziation während der NS-Zeit und die justizielle Ahndung in den Nachfolgestaaten des Dritten Reichs," Kriegsverbrechen, NS-Gewaltverbrechen und die europäische Strafjustiz von Nürnberg bis Den Haag, eds. Heimo Halbrainer and Claudia Kuretsidis-Haider (Graz: Verlag Clio, 2007), 103-117 (table on p. 111). For West Germany cf. also Claudia Bade, “'Das Verfahren wird eingestellt.' Die strafrechtliche Verfolgung von Denunziation aus dem Nationalsozialismus nach 1945 in den Westzonen und in der frühen BRD," Historical Social Research 26.2/3 (2001), 7085.

14 1965-2012 Rüter led a huge documentation project on Nazi crimes trials. See C. F. Rüter (ed.), Justiz und NS-Verbrechen. Die deutschen Strafurteile wegen nationalsozialistischer Tötungsverbrechen (West German series: 49 volumes) and DDR-Justiz und NS-Verbrechen (East German series: 14 volumes). The two series had been published by Amsterdam University Press and different German publishing houses. The online edition is hosted by https://www.junsv.nl/, licenses are distributed by https://www.expostfacto.nl/junsvlizenz.html (accessed December 2019).

15 Protocol Additional to the Geneva Conventions of August 12, 1949, and relating to the Protection of Victims of Non-International Armed Conflicts (Protocol II), June 8,1977 . The text is available on the website of the International Committee of the Red Cross, https://ihl-databases.icrc.org/applic/ihl/ihl.nsf/Treaty.xsp?docum entId=AA0C5BCBAB5C4A85C12563CD002D6D09\&action=openDocument (accessed December 2019). 
war crimes. One was a criminal offense which "contradicts the natural demands of humanity and the generally accepted fundamental principles of international law or martial law, committed against members of the armed forces or the civil population of a country which was at war with the German Reich or the territory of which was occupied by German troops". ${ }^{16}$ The other kind of Nazi war crime could be directed against any person, including Germans and Austrians: "Guilty of the same crime is anybody who, in the actual or assumed interest of the German armed forces or the Nazi tyranny, during that war and in connection with military acts or with acts of militarily organized squads, willfully has committed or caused deeds which contradict the natural demands of humanity." 17

Many of the offenses which the Austrian legislature of 1945 had called war crimes also fulfilled the elements of the crimes murder or manslaughter, and many defendants were sentenced both for Nazi war crimes according to $₫ 1$ of the War Criminals Act and for murder according to $₫ 134$ of the Austrian penal code of 1852 . This applied especially to cases which fell under the clause of $\$ 1$ (2) War Criminals Act, because the courts tended to prefer the respective clauses of traditional Austrian criminal law. The texts of the verdicts provide no reason for that, but it seems obvious that for the judges, the War Criminals Act $\$ 1$ (2) deviated too far from what had been understood as a war crime in traditional martial law.

The last part of this article presents some considerations about what the Austrian lawmakers called "violation of human dignity", and its punishment. "Macro-criminality" ordered by the state, such as mass shootings behind the front, the running of extermination camps, or the transformation of hospitals into killing sites, did not fit into legal systems conceived for the purpose of prosecuting criminal offenses by individuals. These new crimes included genocide and mass murder committed by "public" institutions and their henchmen, but also countless individual acts of cruelty and inhumane or degrading treatment. Although many European constitutions contain a catalogue of fundamental civil rights, there existed hardly any procedure granting individuals to recourse for mental or bodily harm inflicted through a violation of those rights.

After the atrocities committed in Nazi concentration camps and during mass shootings it was inevitable that many people would try to gain impunity by claiming that said atrocities were tolerated or even ordered by the state. The Allied occupation administration in Germany, as well as sev-

16 “Kriegsverbrechergesetz," $\mathbb{1} 1(1)$.

17 “Kriegsverbrechergesetz," \$1 (2). 
eral European states, pre-empted this by promulgating retroactive laws enabling the judiciary to punish those who had perpetrated such atrocities. Despite the atrocities committed during the First World War by the German army in Belgium and France and then by the Austro-Hungarian army in the Eastern war theater, hardly any judicial system was prepared to face that problem, ${ }^{18}$ so different legal concepts were adopted. The most powerful, which was eventually accepted worldwide, was that of "crimes against humanity" as described in the London Charter for the Nuremberg Trial and in Control Council Law No. 10.

The use of this term in international politics goes back to 1915, when Great Britain, France, and Russia in a joint statement denounced the massacres of the Turkish army and declared that they would hold personally responsible all members of the Ottoman government for that crime against humanity. ${ }^{19}$ But after 1918 the term disappeared almost completely. The Moscow Declaration of 1943 did not use the term "crimes against humanity", but "atrocities" which had been "perpetrated by Hitlerite forces". ${ }^{20}$ The legal concept of crimes against humanity is that the perpetrator not only inflicts individual harm to the victim, but also deprives that person of fundamental rights inherent to any human being. "Humanity" thus refers not only to the opposite of inhumane behavior, but also to humankind as a whole.

The Austrian legal concept was different. It started not from humankind, but from human dignity. From the catholic point of view shared by most of the Austrian lawmakers of that time, it clearly did not target the individual as part of the human race, but as individual per se. And it is not

18 The only exception was Belgium where already in 1917 a law concerning collaboration had been passed. The law was amended in 1934 and provided a legal-nonretroactive-basis for the Belgian post war trials. Cf. Nico Wouters, "Völkermord vor belgischen Militärtribunalen am Beispiel der gerichtlichen Ahndung von Verbrechen an Juden und Jüdinnen (1944-1951)," Kriegsverbrechen, eds. Halbrainer and Kuretsidis-Haider, 171-191 (the laws are presented on p. 172-173).

19 The notice to the Sublime Porte, issued on the request of the French government, is mentioned in a telegram of the U.S. embassy in Constantinople to the State Department, stored at the National Archives, R.G. 59, 867.4016/67, published as facsimile in the internet on the web site of the Armenian National Institute, Washington DC, http://www.armenian-genocide.org/popup/affirmation_window.html ?Affirmation=160 (accessed December 2019).

20 The Statement on Atrocities was one of the four declarations passed at the end of the meeting of Roosevelt, Churchill, and Stalin in Moscow, October 31, 1943. The declaration is available on many internet sites, e.g. the Legal Tools Database of the International Criminal Court https://www.legal-tools.org/doc/3c6e23/pdf/ (accessed December 2019). 
a certain set of rights which is attributed to that individual, but it is his or her personality as a child of God that must be protected by the law. This personality comprises attributes which make him or her a human being, and the most important of those attributes is human dignity, inherent in all creatures of God and derived from the divine nature of the creation of mankind.

In the end both legal concepts had the same effect on postwar jurisdiction: deeds of Nazi perpetrators which intended to dehumanize the victim were criminal offenses, regardless whether or not they had been prohibited by German law at the time. This was a prerequisite for the re-establishment of the rule of law. It was of no further practical importance whether this rule of law was derived from natural law or from a concept of divine rules for human existence, or simply imposed by a victorious army upon the occupied territory. The outcome was that similar definitions had been found for the same Nazi crimes, such as for degrading, hurting and killing people on political, racist, or religious grounds.

In Austrian law up to 1945 there existed no violation of human dignity, but only defamation clauses that concerned disputes between individuals and were therefore no offenses requiring public prosecution. The only exception was the derision of religious feelings or grave acts belittling of other nations, referring to the time of the multi-ethnic Habsburg Monarchy and the old Austrian Criminal Code promulgated in 1852. ${ }^{21}$ The War Criminals Act of June 26, 1945, used the terms "violation of human dignity" and "violation of the laws of humanity" at the same time and made both a criminal offense, if they had been committed in the interests of the Nazi regime.

The War Criminals Act $\mathbb{3}$ (2), which concerned torture, assault, and battery, made clear when this crime had to be punished with the death sentence if the inflicting of severe bodily harm or the setting into a painful or terrifying situation had caused the death of the victim or, if it had been accompanied by severe "violations of human dignity and of the laws of humanity." By imposing the same sentence for killing of a person during torture and for gravely degrading his or her human dignity, the Austrian lawmakers of 1945 took into account that there are forms of torture that can harm the victim to the extent that he or she becomes unable to continue normal life. The reason for this inventive approach could be that the then secretary of Justice, Josef Gerö, had experienced a Nazi concentration

21 "Das allgemeine Strafgesetz vom 27. Mai 1852" (as amended and promulgated on July 31,1945$), \$ 494$. 
camp. It is remarkable that this kind of "social death" of the victim should be treated in the same way as the physical death.

As the court records show, the courts did not always follow the intention of the lawmakers, but in many trials the degrading treatment of both Jewish and non Jewish victims by SS guards, policemen, and ordinary people, e.g. during the pogrom in Vienna in March 1938 or during the Night of Broken Glass in November 1938, played a decisive role in the conviction of the defendant. Although both the Austrian Nazi Banning Act and the War Criminals Act preceded the London Charter of August 8,1945, the Austrian approach to punishing crimes against humanity resembled that of the Allies and the Germans. This shows that the so-called Nuremberg principles represented, in some way, a kind of common sense among democratic forces in Europe at the end of World War II. 


\section{Brother, Black Sheep, or Bastard? \\ Situating the Tokyo War Crimes Trial in the Nuremberg \\ Legacy, 1946-1948}

James Burnham Sedgwick

The International Military Tribunal for the Far East (IMTFE), 1946-1948 -more commonly known as the Tokyo War Crimes Trial or the Tokyo Trial-shares a kinship with the Nuremberg Trial. Together these trials attempted to establish a legal framework to end future wars. To ensure the continuity of this legacy, Tokyo borrowed much from Nuremberg. Tokyo nevertheless struggled to assert itself as more than a simple rehashing of Nuremberg tenets in a Japanese milieu. This identity crisis has had a lasting impact. Was Tokyo a co-genitor of legal precedent or merely a subordinate "next" step in judicial evolution? Should Tokyo's legal interpretations be seen as corruptions of Nuremberg statutes or necessary adaptations? What is the conjoined Tokyo-Nuremberg legacy? Japan's failure to accept responsibility for wartime actions is often seen as symptomatic of the failures of the Tokyo Trial. Conversely, German acceptance of war guilt is championed as one of Nuremberg's great successes. This paper attempts to explain these incongruities by situating the Tokyo proceedings in the Nuremberg legacy. The title question provides a useful framework for examination. This paper demonstrates that Tokyo was in parts Nuremberg's brother, black sheep, and bastard. It concludes, however, that fitting the Tokyo Trial into Nuremberg parameters ultimately worked to the detriment of both trials. Japan was not Germany; Tojo was no Hitler. Only through detailed historical examination of these mistakes can we ensure that they are not repeated by future international tribunals. Only through individual study of both trials will their joint legacy remain a positive one - no matter how flawed the original proceedings.

\section{Brother}

The Tokyo and Nuremberg trials were brethren in a number of ways. They had analogous origins, parallel objectives, and shared legal tenets. Because of these connections, these trials have also been subjected to similar criti- 
cisms. There is therefore some justification in labelling the IMTFE a "brother" to its German counterpart.

The origins of post-World War II international justice lay in the devastation of the war itself. As knowledge of Axis abuses spread during the war, the Allies responded with several international decrials of these violations. The Inter-Allied Joint Declaration on the Punishment for War Crimes (13 January 1942) was the first public condemnation of Axis misdeeds. ${ }^{1}$ In the "Joint Declaration", the Allies specifically declared that:

1. [A]cts of violence ... inflicted upon the civilian populations have nothing in common with the conceptions of an act of war or of a political crime as understood by civilized nations.'

2. [A]mong their principal war aims [is] the punishment, through the channel of organized justice, of those guilty of or responsible for these crimes, whether they have ordered them, perpetrated them, or participated in them.'

3. (a) Those guilty or responsible [of war crimes], whatever their nationality, are sought out, handed over to justice and judged, and (b) that the sentences pronounced are carried out.' ${ }^{2}$

In other words, the Inter-Allied Declaration condemned the waging of inhumane war and declared that war criminals would be dealt with after the war. The "Joint Declaration" was therefore instrumental in the creation of both the Nuremberg and Tokyo trials. On 7 October 1942, a corollary Anglo-American Agreement was issued which promised extensive investigation of war crimes. This led to the establishment of the United Nations War Crimes Commission (UNWCC) a year later. ${ }^{3}$ On December 17 of the same year, London, Moscow, and Washington simultaneously issued a further warning that war criminals would not escape justice. ${ }^{4}$ Similarly, the Moscow Declaration of November 1943 stated that the official objective of the Allied forces was to try war criminals. The formal structure that post-

119 countries signed the Inter-Allied Joint Declaration. The conference included delegates from Australia, Belgium, Canada, China, Czechoslovakia, Free France, Great Britain, Greece, India, Luxembourg, New Zealand, Norway, Poland, the Netherlands, the Union of South Africa, the US, the USSR, and Yugoslavia. M. E. Bathurst, "The United Nations War Crimes Commission," The American Journal of International Affairs 39 (1945), 565-570.

2 Ibid., 566.

3 Ibid., 567; and Egon Schwelb, "Crimes Against Humanity," British Year Book of International Law 23 (1946), 178-226.

4 Bathurst, "The United Nations War Crimes Commission," 567-568. 
war international tribunals was not outlined, however, until the "Big Four" (France, Great Britain, the US, and the USSR) met at the London Conference in August 1945. Together these various international agreements and declarations laid the foundations for the IMTs in both Nuremberg and Tokyo.

Shared declarations of intent did not mean that Nuremberg and Tokyo had identical charters. The Nuremberg Charter was formulated at the London Conference in 1945. The Tokyo version, however, did not come until five months later and was pursuant to the Potsdam Declaration 26 July 1945-not London. ${ }^{5}$ The Tokyo Charter nevertheless borrowed much from London principles. ${ }^{6}$ This led to an unquestionable legal kinship between the Nuremberg and Tokyo trials. Like Nuremberg, the IMTFE tried its accused on similar counts. "Crimes against peace" condemned the accused of planning and carrying out of an "aggressive" war. ${ }^{7}$ A second group of charges fell under the heading of "conspiracy" to commit "murder". This conspiracy charge included killings alleged in the concurrent charge of crimes against peace. The alleged conspiracy also overlapped with a third group of charges that included conventional war crimes and "crimes against humanity". ${ }^{8}$ This "crimes against humanity" charge indicted individuals for responsibility in the wholesale slaughter, rape, enslave-

5 The Potsdam Declaration promised to uphold the terms of the Cairo Conference (1 December 1943), where Britain, China, and the US declared that they were fighting a war to "restrain and punish [emphasis added] the aggression of Japan." Potsdam furthered this objective assuring that "stern justice shall be meted out to all war criminals". IMTFE, "The Cairo Conference," Exhibits Vol. 1, Exhibit No. 1; and IMTFE, "The Potsdam Declaration," Annexes to Judgment Vol. I, Annex No. A-1, 1-4.

6 The "Tokyo Charter" used by the IMTFE changed from the one originally announced by General MacArthur in January 1946. These alterations were generally slight. In late April 1946, for example, the Charter was amended to include justices from India and the Philippines. This amendment is noted -underlined-by Justice Northcroft in his copy of the amended Charter dated 26 April 1946. See: IMTFE, "Charter of the International Military Tribunal for the Far East," Charter, Indictment, Japanese Constitution, Northcroft Collection (Christchurch, NZ: University of Canterbury). For an example of MacArthur's original declaration see: IMTFE, "Special Proclamation, Establishment of an International Military Tribunal for the Far East," Annexes to Judgment Vol. I, Annex No. A-4, 16-18. For an example of the final version of the Charter see: IMTFE, "Charter of the International Military Tribunal for the Far East,” Annexes to Judgment Vol. I, Annex No. A-5, 19-29.

7 For a contemporaneous definition of "aggression" in warfare see: IMTFE, "Convention Defining Aggression,” Exhibits, Vol. 51, Exhibit No. 2329.

8 IMTFE, "Charter of the International Military Tribunal for the Far East," Annexes to Judgment Vol. I, Annex No. A-5, 21. 
ment, murder, or otherwise brutalisation of civilians during the war. ${ }^{9}$ Conventional war crimes included violations of the customs of war, particularly abuses against POWs. In Nuremberg "crimes against peace", "conspiracy", "crimes against humanity", and conventional war crimes were represented as four individual counts of the Indictment. In Tokyo, these four allegations were grouped together in three general charges, ${ }^{10}$ which were further subdivided in 55 specific counts of war crimes. ${ }^{11}$ Tokyo's legal structure was therefore similar but not identical to its German counterpart. Shared origins and legal tenets, however, meant that Tokyo and Nuremberg were much akin in their originating forms.

There is much debate regarding whether or not Nuremberg was without legal precedent. ${ }^{12}$ Because Tokyo attempted to implement Nuremberg's precedents it has attracted similar controversy. This debate mostly surrounds the criminal counts alleged by both trials. As mentioned, both trials indicted the accused for "Common plan or conspiracy", "Crimes against peace", "War crimes", and "Crimes against humanity". Providing, of course, that a link could be made between individual accused and the ordering or commission of such crimes, few have criticised the basis of charges of conventional "war crimes". ${ }^{13}$ The charges of "crimes against peace" and "crimes against humanity", on the other hand, have received

9 IMTFE, "Charter of the International Military Tribunal for the Far East," Annexes to Judgment Vol. I, Annex No. A-5, 21-22.

10 "Crimes against humanity" and conventional war crimes were joined together in the Tokyo Indictment's third general charge.

11 IMTFE, "Indictment," Annexes to Judgment Vol. I, Annex No. A-6, 29-131.

12 This paper does not attempt to judge the merit of calling Nuremberg and Tokyo "precedent-less". Regardless of the conclusions made, this matter and the other legal issues outlined below were-and continue to be-the center of debate.

13 Justices B. V. A Röling (the Netherlands) and Henri Bernard (France) both expressed concerns that individual accused were not actually linked to crimes in Tokyo. Röling maintained, for example, that the evidence had not linked the accused to either crimes against humanity or conventional war crimes. Röling, "Some Points of Law," in Henri Bernard and B.V.A. Röling, Bernard and Röling on Judgment, Northcroft Collection (Christchurch, NZ: University of Canterbury), 13-14. Bernard, on the other hand, argued that "there can be no doubt" of the guilt of the Defendants concerning these charges, but suggested that lack of direct perpetration of the crimes should mitigate some sentences. Henri Bernard, "Dissenting Judgment of the Member from France of the International Military Tribunal for the Far East," (12 November 1948), Northcroft Collection (Christchurch, NZ: University of Canterbury), 12-16. 
extensive debate since their inception. ${ }^{14}$ The most common criticism mounted on these charges is that they constitute ex post facto legislation. ${ }^{15}$ Like Nuremberg, Tokyo has also been labelled "victors' justice"; an elaborate tool for simple vengeance. The clearest example of this is Richard Minear's, Victors' Justice: The Tokyo War Crimes Trial, a book regarded by many as the seminal work on the subject. ${ }^{16}$ Others contend that Tokyo, like its counterpart in Germany, was merely a vehicle of power politics. In 1949, for example, K. K. Basu concluded an article in the Indian Law Review writing: "With all the legal subtleties argued before it, with all the verisimilitudes of trial at law, there was nothing judicial about the Tokio [sic] tribunal. It remained throughout a mere 'manifestation of power'."17 The legal kinship the IMTFE shared with Nuremberg law therefore made it vulnerable to similar criticism.

Nuremberg and Tokyo shared common objectives as well as kindred origins and legal foundations. In his introductory remarks to the IMT Nuremberg on 20 November 1945, President of the Tribunal Lord Justice Geoffrey Laurence avowed that:

The Trial which is now about to begin is unique in the history of the jurisprudence of the world and it is of supreme importance to millions of people all over the globe. For these reasons, there is laid upon everybody who takes any part in this Trial a solemn responsibility to dis-

14 For one of the best contemporaneous discussions on the contentiousness of "crimes against humanity" see Schwelb's work. He describes the three most controversial points: First, the phraseology of the charge contained penal sanctions against individuals in a time of peace as well as at war. Secondly, the application of the charge against any civilian population "implies that civilian populations are protected against violations of international criminal law also in cases where the alleged crimes have been committed by sovereign states against their own subjects." Finally, the stipulation that "crimes against humanity" were applicable whether the domestic law of the country had been violated or not appeared in his mind "to establish the absolute supremacy of international law over municipal law." Schwelb, "Crimes Against Humanity," 178-179.

15 In other words, whether or not the trials applied new laws retroactively to the accused and held them accountable for committing crimes that were legal at the time of commission. K. K. Basu, "Tokio Trials," Indian Law Review 3 (1949), 2528; Gordon Ireland, "Ex Post Facto From Rome to Tokyo," Temple Law Quarterly 21 (July 1947), 27-49; and Gordon Ireland, "Uncommon Law in Martial Tokyo," The Year Book of World Affairs 4 (1950), 54-104.

16 Richard H. Minear, Victors' Justice: The Tokyo War Crimes Trial (Princeton, NJ: Princeton University Press, 1972).

17 Basu, "Tokio Trials," 30. 
charge their duties without fear or favor, in accordance with the sacred principles of law and justice. ${ }^{18}$

These words make it clear from the start that Nuremberg participants were acutely aware of their place in history. This sense of destiny was equally apparent in Tokyo. Even when questioning the trial's jurisdiction, Defence counsel Ben Blakeney admitted that "The responsibility before history of this Tribunal and of us who play our several parts here is tremendous, aweinspiring." ${ }^{19}$ Likewise, International Prosecution Section (IPS) member Christmas Humphreys wrote in his Japan memoirs that "even the hardboiled lawyers realised that this, whatever else it was, was history." 20

Grounded in this deep awareness of the importance of their work, participants at both Nuremberg and Tokyo sought to formulate precedents for future international tribunals. In Tokyo, the IMTFE was seen as a progressive step in the evolution of international law initiated at Nuremberg. Unsurprisingly, the prosecution and justices involved were among the foremost champions of Tokyo's role in writing legal history. Steeped in "natural law" doctrine, but seeking positivist outcomes, Chief Prosecutor Joseph B. Keenan and fellow IPS member Brendan F. Brown called Nuremberg and Tokyo, "the original cells from which a fully developed specimen of international criminal law will evolve." ${ }^{21}$ Daniel Sutton, a col-

18 Nuremberg Trial Proceedings Vol. 2, The Avalon Project at Yale Law School. http:// www.yale.edu/lawweb/avalon/imt/proc/11-20-45.htm (accessed 9 September 2006).

19 Ben Bruce Blakeney, "International Military Tribunal: Argument for Motions to Dismiss," The American Bar Association Journal 32 (1946), 523. See also: Brendan F. Brown, "Red China, the Tokyo Trials, and Aggressive War," Louisiana Bar Journal 3 (January 1956), 145; Solis Horwitz, "The Tokyo Trial," International Conciliation 465 (November 1950), 475 and 542; Christmas Humphreys, Via Tokyo (London: Hutchinson \& Co. (Publishers) Ltd., 1948), 83; Delfin Jaranilla, "Concurring Opinion: By the Honorable Mr. Justice Delfin Jaranilla Member from the Republic of the Philippines," (1 November 1948), Northcroft Collection, 4-5; and B. V. A. Röling, "Opinion of Mr. Justice Röling, Member for the Netherlands," (12 November 1948), 1 and 51.

20 Humphreys, Via Tokyo, 83.

21 Joseph B. Keenan and Brendan F. Brown, Crimes Against International Law (Washington: Public Affairs Press, 1950), 160. See also: Horwitz, "The Tokyo Trial," 541; A. Frederick Mignone, "After Nuremberg, Tokyo," Texas Law Review 25 (1946-1947), 475-478; R. Quentin Quentin-Baxter "The Task of the International Military Tribunal at Tokyo," New Zealand Law Journal 25 (7 June 1949), 133-134 and 137; and Ronald H. Quilliam, "'Report on the Proceedings of the International Military Tribunal for the Far East', Letter to the Prime Minister of New Zealand," (29 January 1948), Northcroft Collection, 16. 
league of both Keenan and Brown, later wrote that the IMTFE was "one of the first steps, but a long and upward step, taken to replace a system of force with a system of law and order." 22 Members of the Tribunal were equally effusive on this point. New Zealand IMTFE Justice Erima $\mathrm{H}$. Northcroft declared that "The substantial purpose of the trials at Nuremberg and at Tokyo will have been achieved if a code of international law emerges." 23 Despite being widely held as a critic of the IMTFE, Dutch Justice B. V. A. Röling also extolled its role in a new era of conflict resolution, saying: "I am still convinced that the Trial was a kind of milestone in legal development, and the attitude on which the judgements were based is absolutely necessary in the atomic era." ${ }^{24}$ After the war, many felt that a new enforcement regime was needed for war crimes. Together, participants at Nuremberg and Tokyo set out to codify and establish the international criminal law necessary to achieve these ends.

Along with kindred beliefs in their roles in the history and the evolution of law, participants at both Tokyo and Nuremberg sought to deter individuals and nations from future wars of aggression. Justice Robert $\mathrm{H}$. Jackson, US Prosecutor in Nuremberg reported to President Truman in October 1946 that,

The four nations through their prosecutors and through their representatives on the Tribunal, have enunciated standards of conduct which bring new hope to men of good will and from which future statesmen will not lightly depart. These standards by which the Germans have been condemned will become the condemnation of any nation that is faithless to them. ${ }^{25}$

22 Daniel N. Sutton, "The Trial of Tojo: The Most Important Trial in All History?" American Bar Association Journal 36 (February 1950), 165.

23 Erima H. Northcroft, "Document 728: 'The New Zealand Member, International Military Tribunal for the Far East to the Deputy Secretary of External Affairs', Tokyo, 20 April 1948 (Received 30 April)," PM 106/3/22, Documents on New Zealand External Relations, Volume II: The Surrender and Occupation of Japan, ed. Robin Kay (Wellington, NZ: P. D. Hasselberg, Government Printer, 1982), 1718. See also Erima H. Northcroft, "Memorandum for the Right Honourable the Prime Minister Upon the Tokyo Trials 1946-1948, By the Honourable Mr. Justice Northcroft," (17 March 1949), Northcroft Collection, 2.

24 B. V. A. Röling and Antonio Cassese (ed.), The Tokyo Trial and Beyond: Reflections of a Peacemonger (Cambridge, UK: Polity Press, 1993), 86.

25 "Report of Robert H. Jackson, United States Representative to the International Conference on Military Trials: London, 1945," (7 October 1946), The Avalon Project at Yale Law School. http://www.yale.edu/lawweb/avalon/imt/jackson/jack 63.htm (accessed 9 September 2006). 
In his publication with Brendan Brown, Tokyo Chief Counsel Joseph Keenan echoed his Nuremberg counterpart's sentiments averring that, "this trial will probably deter many future leaders from resorting to crimes against international law." 26 Justice Northcroft concurred, concluding that the combined efforts of Nuremberg and Tokyo had validated the idea of holding individuals accountable for the actions of a state. He continued that, "In this way a warning has been given to national leaders who contemplate aggression." 27 Others were sceptical that Tokyo would actually have a preventative effect, but were nevertheless convinced that this should be one of its objectives. Frederick Mignone (IPS), for example, wrote that "the world needs all the preventative protection possible against the rise of new leaders willing to gamble anew the lives of millions of helpless subjects." 28 Justice Röling agreed saying simply: "The dreadfulness of World War II ... made us realize the necessity of preventing wars in the future." 29

The close connection between Nuremberg and Tokyo therefore manifested itself in a number of ways. Both originated in similar Allied declarations and conferences promising the punishment of Axis war criminals. As a result, both trials shared a number of legal tenets. In fact, it was hoped that Tokyo would become the first trial to substantiate the Nuremberg charges of international "conspiracy", "crimes and against peace", and "crimes against humanity". Similar law led to a shared burden of legal criticism furthering the sense of kinship between the trials. Finally, as the first steps taken towards codifying international criminal law, both the IMTFE and IMT Nuremberg shared the common objective of deterring future aggression. It therefore becomes apparent upon review that, on certain levels at least, the IMTFE was indeed a "brother" to its German precursor.

\section{Black Sheep}

There was-and is—no way to deny the kinship these trials shared. But if the Tokyo Trial is recognised as a brother to Nuremberg, it must also be acknowledged that it was, at best, the black sheep of the family. Nuremberg is often painted as the originator of international criminal justice. The validity of its judicial model is debated, but its importance as a pioneer is

26 Keenan and Brown, Crimes Against International Law, 160.

27 Northcroft, "Memorandum", 11.

28 Mignone, "After Nuremberg, Tokyo," 490. See also: Sutton, "The Trial of Tojo," 165.

29 Röling, “Opinion,” 45. 
unquestioned. The work of Tokyo jurists, on the other hand, is rarely acknowledged let alone commended. Participants in Tokyo were uncomfortable with its billing as Nuremberg's "little Brother" from the start. Indeed, during his introductory remarks to the court, IMTFE President Sir William Flood Webb declared that "There has been no more important trial in history." 30 Webb's assertion aside, Tokyo became the embarrassing and near-forgotten scion of the Nuremberg family tree. This is not to say that the IMTFE has been completely ignored. Compared to Nuremberg, however, it remains banished to the periphery of media, academic, judicial, and international consciousness; an historical afterthought.

This mantra of historical neglect may seem pat but there is undeniable truth to it. To verify this assertion one need not stray farther afield than a good local library. Any search for the Nuremberg proceedings will be met with a veritable stack of books from the likes of Michael R. Marrus, Richard Overy, Bradley F. Smith, Telford Taylor, Ann and John Tusa, and Robert K. Woetzel to name but a few. ${ }^{31}$ A similar query for the Tokyo Trial will yield notably less. It is not likely that more than a handful of books will be available. Moreover, the works that are common are generally out of date and unsatisfactory. The three most likely search results are Richard Minear's, Victors' Justice, Philip Piccigallo's The Japanese on Trial: Allied War Crimes Operations in the East, 1945-1951,32 and Tim Maga's Judgment at Tokyo: The Japanese War Crimes Trials. ${ }^{33}$ Although admirable, Minear's selflabelled "polemical" work is now over thirty years old and outmoded. Piccigallo's work has also been in publication for nearly thirty years. Furthermore, the IMTFE is only part of his much larger account of all trials of Japanese war criminals in Asia. Finally, despite its misleading title, Maga's work uses only 35 of its total 181 pages to cover the IMTFE. The current IMTFE historiography therefore leaves much to be desired.

30 IMTFE, Transcripts of Proceedings (3 May 1946), 1.

31 Michael R. Marrus, The Nuremberg War Crimes Trial, 1945-1946: A Documentary History (Boston: Bedford Books, 1997); Richard Overy, Interrogations: The Nazi Elite in Allied Hands, 1945 (New York: Viking Penguin, 2001); Bradley F. Smith, Reaching Judgment at Nuremberg (New York: Basic Books, Inc, Publishers, 1977); Telford Taylor, The Anatomy of the Nuremberg Trials: A Personal Memoir (New York: Alfred A Knopf, 1992); Ann Tusa and John Tusa, The Nuremberg Trial (New York: Atheneum, 1984); and Robert K. Woetzel, The Nuremberg Trials in International Law (New York: Frederick A. Praeger, Inc., 1960).

32 Philip R. Piccigallo, The Japanese on Trial: Allied War Crimes Operations in the East, 1945-1951 (Austin, TX: University of Texas Press, 1979).

33 Timothy P. Maga, Judgment at Tokyo: The Japanese War Crimes Trials (Lexington, KY: University Press of Kentucky, 2001). 
Whether or not this disproportion existed during the trials' proceedings is less clear. An analysis of Japanese media coverage of the IMTFE completed by US occupation authorities in September 1946 concluded that "Contrary to expectation, the trial of 28 Japanese citizens, singled out by the Allied Powers for prosecution on war guilt charges, has not been a leading topic for comment in the nation's periodicals." ${ }^{34}$ The quantity of contemporary trial coverage in the West reveals a similar level of indifference. Generally, the amount of discussion garnered by German trials in contemporary media and academic writings far outstripped that of Japanese proceedings. Between 1945 and 1951, for example, 26 law journals published 36 articles concerning Japanese war crimes trials. Over the same period, 69 articles about German trials were printed in 38 legal journals. The New York Times and the Washington Post demonstrate a comparable disparity in popular media coverage. Between August 1945 and May 1951-the period of Allied war crimes operations-the New York Times carried 145 articles about Japanese trials. Over the same period, it printed 246 articles on German trials. This disproportion was even greater in the Washington Post, where between the same dates it printed more than twice as many (146) articles on Germans trials than it did on those on the Japanese (71). "Figure 1: Comparison of New York Times Coverage of Japanese and German War Trials, August 1945 - December 1948" reveals that coverage of German trials remained pre-eminent even over a period dominated by Japanese trials. The majority of these articles focused on the IMTs in Tokyo and Nuremberg. The disproportion between January 1947 and October 1948 is especially noteworthy since this period came long after the end of the Nuremberg Trial. Even when Tokyo was the only "major" war crimes trial underway, it was outstripped by coverage of "minor" German trials. ${ }^{35}$

34 Media Analysis Division, Civil Information and Education Section, Supreme Commander for the Allied Powers (SCAP), "Publication Analysis," (11 September 1946), (Christchurch, NZ: Harold J. Evans Papers, private collection).

35 For more on contemporary media, academic, and internal views on the Tokyo Trial see: James Burnham Sedgwick, "Western Reaction to Allied War Crimes Operations in the Far East, 1945-1951: Apathetic and Insignificant?" MA Thesis (Christchurch, NZ: University of Canterbury, 2004). 
Figure 1:

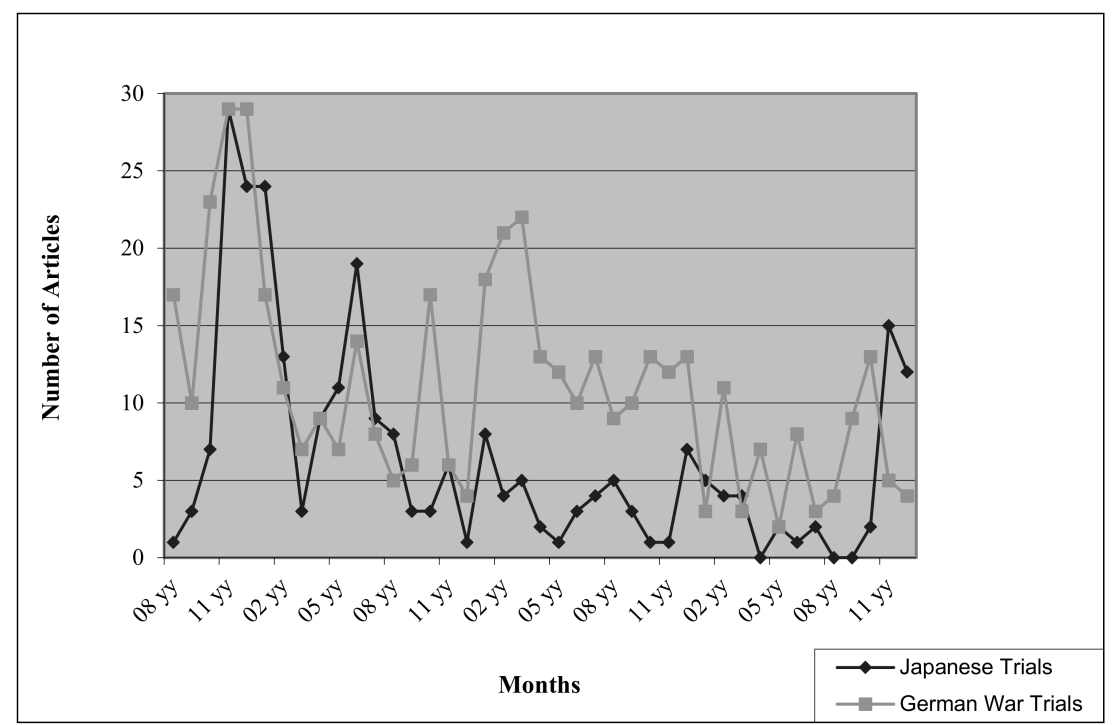

Comparison of New York Times Coverage of Japanese and German War Trials, August 1945-December 1948

These results support the contention that Tokyo remained the forgotten son of international justice for the majority of its proceedings. The trial itself is not all to blame for this lack of attention. In many ways, its black sheep status lay in the global climate of the era. Perhaps the most readily perceivable reason that knowledge of Tokyo beggared in comparison to that of Nuremberg was timing. Simply put, Nuremberg came first, striking while the iron was hot and effectively making Tokyo the "first" loser. Similarly, for a trial of its magnitude, the Nuremberg Trial was relatively brief (11 months long). Tokyo overstayed its welcome in the public eye taking over two and half years. It is also possible that the public was numbed into apathy after several years of revelations about horrendous crimes. Geography undoubtedly played a significant role. Nuremberg was both more accessible to journalists and more interesting to the Western public. People in the West had little familiarity with the alien, difficult to remember names of Japanese "villains". The Nazi accused, on the other hand, largely represented the bogeymen of wartime society in the West. Daily coverage was just too difficult in Tokyo; and not required. Additionally, other than the most gruesome testimonies, much of Tokyo's time was spent on legal issues. Although of note to scholars, these did not have wide public appeal. 
Of course, Nuremberg involved legal matters as well, but these were generally less disputed than Tokyo's. Finally, other momentous events in Asia detracted from Tokyo coverage but had limited impact on Nuremberg. These included de-colonisation movements in Asia, the birth of the Atomic era, the emergence of the Cold War, and civil war in China.

International conditions were also largely responsible for dictating the tone of IMTFE coverage. The prevailingly negative quality of this coverage better reveals Tokyo's role as black sheep to Nuremberg. In short, Tokyo was a disappointment. Nuremberg was seen as an intrepid legal pioneer. Although imperfect, it had laid the foundation for future justice. As the first test case Tokyo failed under the burden of trying to squeeze the Japanese situation into the pat Nuremberg framework. Instead of reifying the German precedent, Tokyo made it more convoluted, controversial, and cumbersome. Worsening Cold War tension, especially the emerging Korean conflict, did little to appease critics. Their growing disenchantment coloured contemporary writings on Tokyo. The once optimistic proponents of a peaceful global community based on the deterrent of criminal accountability found themselves embittered when confronted by the harsh post-Tokyo reality. The Nuremberg and Tokyo Judgments were revealed as impotent just years after their pronouncement. Because it was unsuccessful in solidifying Nuremberg tenets, Tokyo was often saddled with blame for the "failure" of both trials.

IPS member Brendan Brown offers a poignant example of this disillusionment. In 1950, Brown co-authored a book with Chief Prosecutor Keenan that extolled the "new" laws of Nuremberg and Tokyo. "[T]he Tokyo and Nuernberg war crimes trials were manifestations of an intellectual and moral revolution" they wrote, a revolution, "which will have a profound and far reaching influence upon the future of world society." 36 Only six years later, a disaffected Brown lamented that, "If all truth is relative and subjective, then all law, including international law, is in essence power, and aggressive war is whatever those who have the power choose to declare it to be at any particular time." ${ }^{37}$ Written in reaction to the failure of IMTFE nations to enact their precedent against Chinese and Soviet aggression in Korea, Brown's words help explain why Tokyo has slipped into relative anonymity and why coverage of the trial tended to be negative.

Criticism of the Tokyo proceedings was not unique to this post-trial period. Jessica C. E. Gienow-Hecht's "Trial by Fire: Newspaper Coverage of

36 Keenan and Brown, Crimes Against International Law, v-vi.

37 Brown, "Red China," 153. 
the Nuremberg Proceedings" argues that press coverage of the Nuremberg Trial was censored to project a positive image of the trial to the German public. This was done to suit the overall aim of occupying forces to use the IMT as a tool for "re-education". ${ }^{38}$ Despite similar efforts by General MacArthur to control the tone of media coverage of the Tokyo Trial, its public image remained largely negative. Time Magazine, for example, called Tokyo, "a third-string road company of the Nurnberg [sic] show ... [where] The German production had a touch of Wagner ... Tokyo's had the flavour of Gilbert \& Sullivan." 39 Similarly, The Press [Christchurch, NZ] regretted the "doleful knowledge" that the IMTFE continued to "drag on" even after 15 months, and concluded that "unlike their fellow war criminals in Germany, who died at least in a blaze of publicity, the Tokyo 25 will die unremembered, even by many of their own countrymen." 40 Academics were also critical. In The Year Book of World Affairs, Gordon Ireland denounced the IMTFE as "not an example of international law at all but no more than a round-about subterfuge by which victorious nations through legal forms avenged themselves on enemy leaders who committed the real crime of being beaten." ${ }^{41}$ Few contemporaries denied the kinship between Tokyo and Nuremberg, but acknowledgement of this bond became increasingly begrudging. By the end the disappointment embodied in Tokyo left it studiously ignored by the press, scholars, and the public at the time and in the decades since. The way that it inspired a combination of embarrassment and disregard in observers casts the Tokyo Trial as the black sheep of Nuremberg's family.

\section{Bastard}

Tokyo's black sheep persona stems mostly from its treatment of the legacy it inherited from Nuremberg. The IMTFE was undoubtedly founded with lofty ideals. As mentioned, its organisers sought to join Nuremberg in establishing a legal framework to end future wars of "aggression". Rather

38 Jessica C. E. Gienow-Hecht, "Trial by Fire: Newspaper Coverage of the Nuremberg Proceedings," Studies in Newspaper and Periodical History: 1995 Annual, eds. Michael Harris and Tom O'Malley (Westport, CT: Greenwood Press, 1995), 167183.

39 “Road Show," Time Magazine 47 (20 May 1946), 24.

40 "Trial of Japan's Leaders: Tribunal Resumes after Recess: 'Almost Forgotten By the World'," The Press (6 August 1947), 7.

41 Ireland, "Uncommon Law", 87-88. 
than reinforcing Nuremberg precepts, however, jurists at Tokyo were forced to reconfigure them. Tokyo's failure to apply "pure" Nuremberg precedent encouraged contemporaries to label it a black sheep. In retrospect, the adaptations made by Tokyo participants also brand the trial as a "bastard" form of Nuremberg law. Tokyo began with parallel origins, kindred objectives, and near-identical law to its German counterpart. By the end, it had taken these commonalities and created an almost unrecognisable entity. In many ways, Tokyo would have been better off establishing its own framework from the beginning. Because it did not, however, it will remain Nuremberg's bastard.

The most fundamental issues were legal. Trying to apply the Nuremberg conventions of "conspiracy", "common plan", and "aggression" in the Japanese setting revealed unforeseen weaknesses in the law. These charges were tailor made for Germany. There was a clear group - the Nazis—with a clear leader-Hitler-that had taken clearly aggressive steps to initiate and precipitate war. In Japan, however, the situation was far more complex. Japan had 17 Cabinets and 16 Prime Ministers in the period investigated by the IMTFE (1927-1945).42 If there was one continuous "leader" it was Emperor Hirohito. Debate continues, however, over the extent to which the Emperor operated as a mere figurehead or played an active role in Japan's "aggression”. Regardless, he was certainly no Hitler. Furthermore, this already varying number of governments was almost infinitesimally segmented by internal schisms, secret societies, and interest groups. Prosecutors in Tokyo therefore had difficulty sustaining the argument that pre-war Japan's movement towards war was the result of a clear conspiracy and common plan. Despite the inherent probative challenges, the IPS persisted in mirroring Nuremberg charges in Tokyo. This stubborn adherence to Nuremberg precepts opened Tokyo up to criticism that discredited the work of both IMTs.

Things were further complicated by trying to apply the Nuremberg definition of "aggression" to the Japanese context. The Nuremberg Indictment placed the beginning of the "common plan" with the founding of the Nazi Party in 1920, and the start of "aggression" with the invasion of Austria in March 1938. The exact start of war in Asia is more difficult to define. Many Western, particularly American, scholars contend that the struggle did not become a global one until the attack on Pearl Harbor and the invasion of

42 Prince Konoe Fumimaro was Prime Minister for two non-consecutive terms. He committed suicide after the war and was therefore never brought to trial. 
other Western settlements in Asia in December 1941.43 Others point to the Japanese invasion of China in $1937,{ }^{44}$ and still others suggest that a "Great Asian War", also known as the "15 Year War", began with the Japanese envelopment of Manchuria in late $1931 .{ }^{45}$ The IMTFE, for its part, alleged that a Japanese conspiracy to wage war dated as far back as 1927 with the so-called "Tanaka Memorial" 46 and the assassination of the Manchurian warlord Zhang Zuolin (Chang Tso-Lin). Tokyo therefore faced far greater difficulty than its German counterpart in proving a precise flashpoint of Japanese "aggression". The challenge of tying this together in a "conspiracy" to wage a "war of aggression" has led to criticism of the Tokyo Indictment and its creators.

Complicating matters even further is the debateable neutrality of the Allied "victims" of Japanese aggression. Justices Henri Bernard (France), Radhabinod Pal (India), and B. V. A. Röling (the Netherlands), for example, saw the rise of communism in China as a legitimate threat to Japanese possessions on the continent. Although not an absolution of Japanese guilt,

43 Basil Collier, The War in the Far East, 1941-1945: A Military History (London: William Heinemann Ltd., 1969); John Costello, The Pacific War, 1941-1945 (London: William Collins Sons and Co. Ltd., 1981); and John J. Sbrega, The War Against Japan, 1941-1945: An Annotated Bibliography (New York and London: Garland Publishing, Inc., 1989).

44 John Hunter Boyle, China and Japan at War, 1937-1945: The Politics of Collaboration (Stanford, CA: Stanford University Press, 1972); James C. Hsiung and Steven I. Levine (eds.), China's Bitter Victory: The War with Japan, 1937-1945 (Armonk, NY: M. E. Sharpe, 1992); Hsu Long-hsuen and Chang Ming-kai, History of the Sino-Japanese War (1937-1945), Wen Ha-hsiung (trans.) (Taipei: Chung Wu Publishing Co., 1972); Hu Pu-yu, A Brief History of the Sino-Japanese War (1937-1945) (Taipei: Chung Wu Publishing Co., 1974); and Dick Wilson, When Tigers Fight: The Story of the Sino-Japanese War, 1937-1945 (New York: Viking Press, 1982).

45 Peter Duus, Ramon H. Myers, and Mark R. Peattie (eds.), The Japanese Wartime Empire, 1931-1945 (Princeton, NJ: Princeton University Press, 1996); Saburo Ienaga, The Pacific War: World War II and the Japanese, 1931-1945 (New York: Pantheon Books, 1978); and The Sino-Japanese Conflict 1931-1941: Prelude to Pearl Harbor Volumes 1-5 (Nedeln, Liechtenstein: Kraus Reprint, 1980).

46 The "Tanaka Memorial" was a directive purportedly presented to Emperor Hirohito on 25 July 1927 by Japanese Premier Baron Tanaka Giichi advocating Japanese occupation of Northeast China, and eventually the entire Chinese nation. It has since been proven a forgery. Gavan McCormack, Chang Tso-lin in Northeast China, 1911-1928: China, Japan, and the Manchurian Idea (Folkestone, Kent: William Dawson \& Sons Ltd., 1977), 236. Interestingly, although the IMTFE Prosecution pinpointed the "Tanaka Memorial" (1927) as the beginning of Japanese aggression, it began its Indictment in January 1928. 
they felt that this negated accusations of "aggression" ${ }^{47}$ In fact, Justice Pal contended that US aid to China before 1941 could be considered an act of aggression against Japan. In the very least, Pal asserted that this obviated Japanese "aggression" at Pearl Harbor. ${ }^{48}$ Similar arguments existed concerning the Allied economic blockade imposed on Japan in the late 1930s. ${ }^{49}$ Furthermore, the inclusion of a Soviet member at the IMTFE proved an awkward matter. Once there, the Soviet team forced allegations of Japanese aggression against Russian troops into the Indictment. This was a tenuous contention given the fact that the USSR had not officially declared war on Japan until after its effectual surrender. Including Soviet representatives was a political necessity but members of the Defence, the Prosecution and the Bench found this inclusion embarrassing. ${ }^{50}$ Moreover, these allegations undermined attempts by the Prosecution in Tokyo to reinforce a Nuremberg view of "aggression".

The ideals of Nuremberg were not inappropriate. In fact, they could readily be accepted as positive steps in international conflict resolution. The Tokyo Trial was therefore undoubtedly well-intentioned in trying to reinforce and expand Nuremberg ideals. It was to the detriment of both trials, however, to try to fit Tokyo into Nuremberg parameters. The IMTFE would therefore have been better off creating entirely new precepts designed specifically for a situation that differed significantly from the Germany one. In fact, Tokyo's best successes came in the areas where it showed the most independence and initiative in defining itself.

This is apparent in how Tokyo confronted its linguistic challenges. Four languages-English, French, German, and Russian-were used in Nurem-

47 Henri Bernard, "Remarks Concerning the Draft of Judgment of the Majority [Concerning Part B Chapter V, Vol. I]," (2 July 1948), Bernard and Röling on Judgment, 1-20; Radhabinod Pal (India), "International Military Tribunal for the Far East: Judgment of the Honourable Mr. Justice Pal, Member from India," (30 July 1948), 254-257 and 312-314; and B. V. A Röling, "Judgment Part B, Chapter III: 'Japanese Aggression against the USSR'," (28 July 1948), Bernard and Röling on Judgment, 6-7.

48 Pal, "International Military Tribunal for the Far East," 261-262 and 1022-1024.

49 See for example: Röling, "Judgment Part B, Chapter III," 27 and 30-31.

50 Bernard, "Dissenting Judgment," 11; Ben Bruce Blakeney, "International Military Tribunal: Argument for Motions to Dismiss," The American Bar Association Journal 32 (1946), 476; George F. Blewett, "Victor's Injustice: The Tokyo War Crimes Trial," American Perspective (Summer 1950), 287-288; Pal, "International Military Tribunal for the Far East," 241-246; and Carrington Williams, "The Tokyo War Crimes Trial before the International Military Tribunal for the Far East," International Humanitarian Law: Origins, eds. John Carey, William V. Dunlap, and R. John Pritchard (Ardsley, NY: Transnational Publishers, 2002), 121-122. 
berg. Interpreters for these languages were readily available, and thus translation services were relatively straightforward and rapid. The logistics of the Japanese situation, on the other hand, forced Tokyo organisers to bastardise the Nuremberg approach. In Tokyo, there were officially only two languages; English and Japanese. These two alone presented difficulties because of inherent differences between the two languages. There was also a deficiency of professional translators in the field. On top of this, the trial saw testimony in numerous other languages. This presented a situation where Nuremberg procedure could offer no help to its Japanese brother. The Tokyo Trial eventually surmounted these translation issues but not before they greatly prolonged its proceedings. These administrative issues demonstrate that not all the forced adaptations made to the Nuremberg model in Tokyo had negative results. Indeed, in this case, the resulting adjustments may well be one of Tokyo's greatest legacies. The lessons learned from such a huge project have yet to be satisfactorily investigated. When this is done, however, it is likely that the Tokyo approach to language issues will prove more relevant to modern international criminal law than those legitimated in Nuremberg.

Tokyo was also groundbreaking as an example of international cooperation not seen in Nuremberg. In this area Tokyo was again confronted with a situation about which Nuremberg could offer little guidance. The German trial was the work of four major powers. Relations between these countries were not "simple" but interaction was based on accepted bigpower diplomacy. Tokyo was also dominated by major powers. Indeed, many experts contend that it was a wholly American trial. ${ }^{51}$ It was more than that, however. In total, eleven nations of varying international status participated in the IMTFE. Major powers such as China, France, Great Britain, the USSR, and the US all played significant roles. So too did less powerful countries such as Australia, Canada, and New Zealand, and the Netherlands. Moreover, two nations not yet officially formed-India and

51 There is much debate about the extent to which the IMTFE was dominated by the US. In July 1946, New Zealand Justice Northcroft, for example, complained to the New Zealand Department of External Affairs that "the whole thing is an American 'show'”. Erima H. Northcroft, "Document 681: 'The New Zealand Member, International Military Tribunal for the Far East to the Secretary of External Affairs', Tokyo, 2 July 1946," PM 59/2/49, Documents on New Zealand External Relations, Volume II: The Surrender and Occupation of Japan, 1613. More recently, historian Donald Cameron Watt has argued that American predomination was an expected necessity. Donald Cameron Watt, "Historical Introduction," The Tokyo War Crimes Trial: Index and Guide, Vol. I, eds. R. John Pritchard and Sonia Magbanua Zaide (New York: Garland Publishing, 1987), vii-xxiii. 
the Philippines-were represented with both justices and prosecutors. Burma was similarly given standing with a prosecutor. The adjustments made in Tokyo to accommodate its greater international diversity may help label Tokyo a bastard to the Nuremberg processes. On the other hand, these changes also represent some of the trial's greatest accomplishments.

The Tokyo Trial was an international military tribunal in a way that defies labelling as a simple replication of Nuremberg. The greater complexity of international relations meant that Tokyo experienced internal challenges that Nuremberg precedent had no answer for. Developing Cold War tensions created a rift between Soviet and other representatives. These tensions existed in Nuremberg, but by the time the IMTFE began Cold War politics had become the diktat of international diplomacy. There was also significant resentment between British Commonwealth representatives and the Americans. A more significant divide existed between the English speaking countries-which dominated numerically-and other nations. The extent that "lesser" powers were able to impact the trial is also debated. The fact is, however, that they were there, and they were included. Moreover, the President of the Tribunal was an Australian; not an American, Briton, Frenchman, or Russian. Nuremberg may prove a sound instructive example for future European tribunals, but Tokyo represents the first true example of a global one. The interplay, successes, and failures of running this truly international organisation have received scant attention. This is unfortunate, because these may prove to be the most lasting legacies of the IMTFE. Traditionally, the legacy of Nuremberg and Tokyo -when it is discussed at all-has been labelled a joint one. This paper has established, however, that Tokyo's relationship to Nuremberg was as much a divergent one as it was a shared kinship. The conjoined legacy of Nuremberg and Tokyo is revealed as confusing and unsatisfactory. It is therefore timely to turn this discussion towards how the Tokyo and Nuremberg legacies should be regarded.

\section{True (Shared?) Legacy}

This study's title poses a question: Is the Tokyo Trial best viewed as Nuremberg's brother, black sheep, or bastard? In parts at least, Tokyo was all of these. It was a "brother" in objectives and legal tenets but a "black sheep" in the eyes of contemporary academia and the media. It can also be viewed as a "bastard" to its precursor's legacy because many of Nuremberg's lessons proved untenable in the Tokyo setting. Tokyo was all of these things, yet it was more. In modern times, international war crimes 
trials are an unfortunately regular-and ongoing-occurrence. Before the end of World War II this was not the case. In fact, until the International Military Tribunal Nuremberg and its counterpart in Tokyo, there had never been an extensive international effort to try war crimes. Perhaps the most effective way for modern international tribunals to learn from the experiences of their predecessors in Nuremberg and Tokyo is to focus less on their conjoined legacy and more on how they met different challenges. Law is an evolution of concepts. If Nuremberg represents the origins, then Tokyo was its first test case. An undoubted kinship exists between these trials but together they present a convoluted and confusing foundation of law. Individually, however, they represent valuable links in an ongoing chain of international criminal jurisprudence.

Because of a relative abundance of sources, Nuremberg has been extensively researched. For the very opposite reason, the IMTFE has been underexamined to say the least. Lessons may yet be garnered from the Nuremberg model. Because of its relative anonymity, however, the Tokyo approach may have more to offer to the ongoing evolution of international criminal law. It was, after all, larger, more international, more complex, and greater in scope than its German associate. The very lack of investigation into the IMTFE demands rectification. This dearth of attention is all the more demanding — and curious - given the enormously complex and controversial nature of the IMTFE. For a large part, the fact that the trial remains controversial is due to its own mistakes. But issues of logistics and scope also make the trial study-worthy. Indeed, the list of debatable topics is nearly endless. It is my hope that papers such as this will encourage a more varied and multidisciplinary approach to the study of international criminal law, particularly in its formative stages. Together Nuremberg and Tokyo make up the earliest multilateral attempts to end impunity for war crimes. Separately, they represent potent examples of what running such trials entails. Only by treating each trial as individual objects of study can we truly hope to understand and benefit from the experiences of these pioneers of international jurisprudence. 


\title{
The Nuremberg Trials and American Jurisprudence: The Decline of Legal Realism, the Revival of Natural Law, and the Development of Legal Process Theory
}

\author{
Rodger D. Citron"
}

\section{Introduction}

More than sixty years ago, the most important trial of the twentieth century - the first Nuremberg war crimes trial of the leaders of Nazi Germanybegan. As time has shown, the Nuremberg trials have significantly influenced the way we think about the rule of law. The literature on the Nuremberg trials is vast. It includes the accounts of the trials written by the lawyers who participated. ${ }^{1}$ It explores the central role of the Nuremberg trials in developing human rights law after World War II. ${ }^{2}$ And it covers a number of other important legal subjects. ${ }^{3}$ In this article, I will discuss the influence of the Nuremberg trials on legal philosophy in the Unit-

* I wish to thank Dean Lawrence Raful, Andrea Cohen, Dan Derby, Alan Hornstein, Beth Mobley, and April Schwartz for their time and assistance, Robert S. Summers for providing a prompt response to a request for more information about Lon Fuller, and Albert Messina for valuable research assistance. Needless to say, they are not responsible for any errors. This article was first published in the Michigan State Law Review 2006, 385-410. An earlier version of this paper was first presented at the Touro Law Center Conference, "Judging Nuremberg: The Laws, the Rallies, the Trials," in 2005.

1 See, e.g., Telford Taylor, The Anatomy of the Nuremberg Trials: A Personal Memoir (New York: Knopf, 1992). Jonathan Bush has described Taylor's book as "the best single account of the international Nuremberg trial." Jonathan A. Bush, "Nuremberg: The Modern Law of War and its Limitations," Columbia Law Review 93 (1993), 2024.

2 See, e.g., Matthew Lippman, "Nuremberg: Forty Five Years Later,", Connecticut Journal of International Law 7 (1991). As Professor Lippman has observed: "The post-World War II human rights movement was motivated in part by a desire to ensure that there would be no repetition of the type of atrocities and abuses which were committed by the German regime, as well as by a pragmatic concern that abuses of state power inevitably would lead to internal strife and renewed international instability." (51).

3 For example, Jonathan Turley has examined the Nuremberg trials as an example of "transformative justice." See Jonathan Turley, "Transformative Justice and the 
ed States, focusing on the decline of legal realism as an autonomous jurisprudential movement, the revival of natural law philosophy, and the emergence of legal process theory.

To understand fully the significance of the Nuremberg trials on American legal thought, it is necessary to first provide a sketch of American legal thought before World War II and the subsequent trials. The most intriguing-though not accepted-jurisprudential development in the decade before World War II was legal realism. Legal realism emerged in the late 1920 s as a jurisprudential movement that criticized the formalist approach to law, expressed skepticism about the influence of the rules of law, and sought to demystify how courts operated and judges made decisions. The legal realists generally urged the incorporation of social science into efforts to understand how courts operated and to improve their operations.

The legal realists were viewed as intellectual provocateurs. By the early 1930s, legal realism had become a prominent jurisprudential movementnot dominant, but extensively discussed. Critics complained that the legal realists divorced morality from law, worshipped at the altar of power, and were engaged in a fruitless quest to impose the precision of scientific methods on the understanding of law and the legal system. As the decade progressed, the emergence of fascism abroad gave these criticisms additional urgency. In the aftermath of World War II, the horrors of Nazi Germany and the emerging totalitarian threat of the Soviet Union contributed to the decline of legal realism as an independent jurisprudential movement.

Two competing legal philosophies emerged as legal realism declined, and both can be understood, in large part, as responses to totalitarianism. The principal response, as Edward Purcell and Richard Primus have argued, was the revival of natural law. ${ }^{4}$ Natural law philosophy, broadly speaking, insists that positive law-statutes, and court decisions interpret-

Ethos of Nuremberg," Loyola of Los Angeles Law Review 33 (2000), 659 (describing the Nuremberg trials as "the trial of the century" and arguing that Nuremberg is a "symbol of our own potential for justice"). Other scholars have explored the influence of the Nuremberg trials on the jurisprudence of Justice Robert Jackson-who served as the lead prosecutor in the first trial-after he returned to the Supreme Court. See, e.g., Jeffrey D. Hockett, New Deal Justice: The Constitutional Jurisprudence of Hugo L. Black, Felix Frankfurter, and Robert H. Jackson (Lanham, MD: Rowman \& Littlefield Publishers, 1996), 267-281 (discussing the influence of the Nuremberg experience on Justice Jackson's First Amendment jurisprudence).

4 See Edward A. Purcell, The Crisis of Democratic Theory: Scientific Naturalism and the Problem of Value ([Lexington]: University Press of Kentucky, 1973), 75; Richard Primus, "A Brooding Omnipresence: Totalitarianism in Postwar Constitutional Thought," Yale Law Journal 106 (1996), 423, 427. 
ing statutes-should be evaluated according to a higher moral law. ${ }^{5}$ After World War II, the United States could no longer embrace a legal philosophy in which morality was detached from the legal system. The other response was the development of legal process theory. The "Legal Process School," as Bruce Ackerman has termed it, was concerned with the institutional structure of government, and emphasized that judges often should defer to the policy choices made by other governmental actors in deciding cases. $^{6}$ This more limited understanding of the judicial role followed from the same concerns over totalitarianism and for democracy.

The topic of this article is enormously broad and spans nearly three decades. Therefore, at the outset, I have taken the following steps to make the topic more manageable.

First, my discussion focuses on three authors: Jerome Frank, Lon Fuller, and Herbert Wechsler. Each man is, deservedly, a towering figure in American jurisprudence. Frank, a New Deal lawyer and, later, a judge on the Second Circuit Court of Appeals, was the author of Law and the Modern Mind, a leading legal realist text. Fuller, a lifelong academic (primarily at Harvard Law School), was a perceptive critic of positivism and championed a secular natural law theory. Wechsler-the only author discussed in this article to have served at the Nuremberg trials, as an advisor to one of the judges on the tribunal from the United States-was a leading figure in the legal process school as it developed in the 1950s.

Second, in order to discuss the relevance of the Nuremberg trials to the development of American jurisprudence, it is necessary to situate the trials in historical and intellectual context. The trials loomed large in world politics during and after World War II, and inspired an extensive debate over

5 To put it another way, natural law also, generally, insists upon the existence of foundational principles of morality that exist apart from the legal rights and duties established by positive law. Natural law philosophy may be defined in relation to the legal philosophy of positivism. See, e.g., Philip Soper, "Some Natural Confusions about Natural Law," Michigan Law Review 90 (1992), 2393, 2395 (noting that, as a "legal theory," natural law "takes its shape from its explicit opposition to legal positivism"); see also infra notes 18-20 and accompanying text.

6 Bruce A. Ackerman, "Law and the Modern Mind," Daedalus 119 (1974), 123 (book review). Ackerman coined the phrase "Legal Process School" to refer to the legal academics who argued that "[s]ound legal decision-making ... was not simply a product of psychological maturity" and that the judge "had an obligation to use only those modes of reasoning 'appropriate' to the judicial role." Ibid. at 123 and note 26. 
their legitimacy. ${ }^{7}$ The Nuremberg trials received extensive press coverage, and widely publicized the nature and extent of the Nazi atrocities during World War II. In addition, the trials were a significant event for legal philosophers. The trials both reflected and contributed to serious post-war concerns about totalitarianism. The debate inspired by the Nuremberg trials, therefore, is one measure of a broader shift in American legal thought, in which legal realism continued to decline as an autonomous jurisprudential movement, natural law philosophy returned to prominence, and legal process jurisprudence emerged.

Part I of the article provides a brief overview of legal realism situating it in relationship to legal formalism, and to positivism and natural law. Part II discusses Jerome Frank, his book Law and the Modern Mind, and the legal realism jurisprudential movement. It then considers criticism of both the book and the movement. Part III examines the influence of events following World War II-in particular, the Nuremberg trials, and more generally, the fear of fascism and concern for democracy inspired by the example of Nazi Germany-on Frank and Fuller, including the revival of natural law. Part IV, likewise, examines the influence of the Nuremberg trials on the development of legal process theory through the example of Herbert Wechsler, focusing on his famous "Neutral Principles" article. Part V concludes with a brief discussion of jurisprudential developments outside the academy, focusing on the Supreme Court's decision in Brown v. Board of Education ${ }^{8}$ as a leading example of the influence of Nazi Germany on post-war case law and legal thought.

\section{Situating American Legal Realism}

\section{A. The Emergence of Legal Realism as a Response to Formalism}

Legal realism in the United States emerged early in the twentieth century as a response to the dominance of formalism in legal thought and practice. Harvard Law School Dean Christopher Columbus Langdell, who devised a new approach to legal education in the 1870 s, is perhaps the archetypal le-

7 See, e.g., Primus, “A Brooding Omnipresence," 430 note 50 (collecting articles); see also Hans Kelsen, "The Rule Against Ex Post Facto Laws and the Prosecution of the Axis War Criminals," Judge Advocate Journal 8 (1945); Bernard D. Meltzer, Comment, "A Note on Some Aspects of the Nuremberg Debate," University of Chicago Law Review 14 (1947), 455.

8347 U.S. 483 (1954). 
gal formalist of this era. ${ }^{9}$ Langdell maintained that law is an inductive science, and "that all the available materials of the science are contained in printed books" of judicial opinions. ${ }^{10}$ For Langdell, as Professor Ackerman has explained, "the task of the legal scholar, like that of the natural scientist, was to transform the disordered data found in judicial opinions and render them intelligible by demonstrating the way in which each decision could be explained in terms of the fundamental legal principles implicit in the Common law."11

Oliver Wendell Holmes, Jr. was an early critic of legal formalism. Although Holmes respected Langdell's contribution to legal education, he disagreed with Langdell on the idea that logic was vital to the development of legal thought. ${ }^{12}$ In his 1881 book The Common Law, Holmes essentially "argued that practical expedients, necessitated by the needs and conflicts of human society, were more central to the development of law than were any logical propositions." ${ }^{13}$ Furthermore, Holmes maintained a skeptical attitude toward the law, defining it as nothing more than "the incidence of the public force through the instrumentality of the courts." 14 By early in the twentieth century, Holmes's criticism of Langdell and legal formalism began to attract followers, planting the seeds that would develop into the legal realism movement. ${ }^{15}$

9 See Thomas Grey, "Langdell's Orthodoxy," University of Pittsburgh Law Review 45 (1983), 11-12 (Langdell's "orthodoxy" was "doubly formal" because, first, "the specific rules were framed in such terms that decisions followed from them uncontroversially when they were applied to readily ascertainable facts," and, second, "one could derive the rules themselves analytically from the principles.").

10 Christopher Columbus Langdell, in "Record of the Commemoration, November Fifth to Eighth, 1886, on the Two Hundred and Fiftieth Anniversary of the Founding of Harvard College" (1887), quoted in Ackerman, "Law and the Modern Mind," 126 note 3.

11 Ackerman, "Law and the Modern Mind," 119-120.

12 See Neil Duxbury, Patterns of American Jurisprudence (New York: Oxford University Press, 1995), 37.

13 Purcell, The Crisis of Democratic Theory, 75 (discussing Oliver Wendell Holmes, Jr., The Common Law [1881]).

14 Oliver Wendell Holmes, “The Path of the Law," Harvard Law Review 10 (1897), 457.

15 See Ackerman, "Law and the Modern Mind," 121 (identifying the first generation, including Holmes and James Bradley Thayer, as critics denying "the assumption of the scientific school that the Common Law had a fundamental structure discernible by the architectonic intelligence"; the second generation as "affected by Progressive politics and Deweyite pragmatism," including Louis Brandeis, Felix Frankfurter, and Roscoe Pound; and the third generation of legal realists, including Frank). 
Holmes's legal philosophy loomed large in the work of Jerome Frank and other legal realists, who shared Holmes's skepticism of Langdell's formalism. They focused their efforts on investigating and explaining how judicial decisions really were made, and "attempted to move beyond the talk of rules and principles heard in the courtroom and the academy and to expose them as myths obscuring most of the principal factors at work in the decision-making process." ${ }^{16}$ The idea of science figured prominently in the efforts of the realists, but it was not the self-contained, inductive logic of Langdell. Instead, the realists were dogged empiricists who consulted the social sciences-Frank, for example, turned to psychiatry-to locate the extra-legal factors that, they argued, determined the outcome of judicial decisions.

\section{B. Positivism, Natural Law, and Legal Realism}

In order to situate realism in relation to positivism and natural law, it is necessary to elaborate, albeit briefly, on the description of those philosophies. Positivism may be defined in relation to natural law, because natural law is-essentially - the opposite of positivism. As Professor Philip Soper has explained: " $[\mathrm{T}]$ he legal positivist claims that no necessary connection exists between law and morality; the natural law legal theorist denies that a sharp separation of these concepts is possible." ${ }^{17}$ A.P. d'Entrèves, a leading natural law philosopher, has elaborated:

[T] he very assertion of natural law is an assertion that law is a part of ethics, [and] its essential function can appear only as that of mediating between the moral sphere and the sphere of law proper.... Perhaps the best description of natural law is that it provides a name for the point of intersection between law and morals. ${ }^{18}$

16 Ackerman, "Law and the Modern Mind," 121.

17 Soper, "Some Natural Confusions about Natural Law," 2395. The positivist view that law and morality are distinct is known as the separability thesis. See e.g., Anthony Sebok, Legal Positivism in American Jurisprudence (New York: Cambridge University Press, 1998), 30.

18 A. P. d'Entreves, The Natural Law (1951), quoted in Lloyd L. Weinreb, "Law as Order," Harvard Law Review 91 (1978), 909 note 1. Historically, the origins of natural law may be traced to works by, among others, Plato and Aristotle, Cicero, and Justinian's Corpus Juris, "and an elaborate theory of natural law was developed in the thirteenth century by Saint Thomas Aquinas." Henry Mather, "Natural Law and Liberalism," South Carolina Law Review 52 (2001), 332. 
Positivism emerged as a response to natural law in the nineteenth century. Historically, under positivism, the focus was not on the content of a law but instead on its pedigree.

Holmes displayed certain positivist tendencies in his jurisprudence. For example, he rejected the natural law notion of the common law as "a brooding omnipresence in the sky" and tended to defer to legislative enactments when they were challenged in court. ${ }^{19}$ There is much more to the definitions of natural law and positivism but, for present purposes, it is necessary to note only that natural law is defined by its concern for morality in law, while positivism is defined by its effort to separate morality from law.

Professor Fuller, as I discuss below, viewed American legal realism as a form of positivism. Although this understanding is not entirely agreed upon by legal philosophers, it is helpful to note the commonalities between realism and positivism. For example, both philosophies distrust the notion that there are certain superior principles of natural law-positivism because the assertion of natural law allows unwritten moral principles to trump actual positive law, and realism because the vagueness of general moral principles does not provide any guidance on how a court may decide a case. With positivism, the inquiry is limited to whether a pronouncement is a valid law. Positivism directs attention to the legislature, which has the authority to repeal existing statutes or to adopt new laws. ${ }^{20}$ Positivism binds the judge, who is limited to saying what the law is. Although American legal realists minimized the importance of rules, they shared with positivism an emphasis on description.

\section{Jerome Frank, Law and the Modern Mind, and Legal Realism}

To simplify matters, I will explain legal realism through the writings of Jerome Frank. Frank practiced corporate law in Chicago and New York City, held a number of high-level positions in the federal government dur-

19 Black \& White Taxicab \& Transfer Co. v. Brown \& Yellow Taxicab \& Transfer Co., 276 U.S. 518, 533 (1928) (Holmes, J., dissenting); Louise Weinberg, "Holmes' Failure," Michigan Law Review 96 (1997), 697 ("We remember Holmes' Supreme Court years for his deference to the political branches, his fatalism in the face of political will.”).

20 Lon L. Fuller, The Law in Quest of Itself (Chicago: The Foundation Press, 1940), 131 ("A tacitly accepted philosophy of positivism seems to me also to underlie the modern preference for legislation as a means of legal reform.”). 
ing the New Deal (including Chairman of the Securities and Exchange Commission), and was appointed to the Second Circuit Court of Appeals in 1941. He wrote a number of books, including Law and the Modern Mind - a provocative and popular legal realist tract-and taught at Yale Law School. Frank was, to be sure, a committed legal realist. ${ }^{21}$

Frank offered a comprehensive critique of formalist legal thought. His views made him an extreme-and extremely clear-spoken - legal realist. In addition, Frank's views were well-known outside the legal academy. His first book, Law and the Modern Mind, sold well when it initially was published in 1930, and went through a number of printings. As a result of his extremism, clarity, and prominence, Frank drew substantial response from both fellow realists and ardent critics of legal realism.

In Law and the Modern Mind, Frank described "the basic legal myth"the myth of certainty-and explained its causes. He did not, however, prescribe a solution for it. Frank proclaimed that "[ $t]$ he law always has been, is now, and will ever continue to be, largely vague and variable." 22 And yet, according to Frank, the necessity of uncertainty in the law-even the existence of it-is denied. Why? To answer this question, Frank turned to psychiatry, in particular, to the child psychiatry of Jean Piaget. ${ }^{23}$ Frank attributed the need for, and belief in, certainty in the law to a child-like need for such certainty. 24

Frank's account of child development was relevant to the myth of legal certainty because, inevitably, according to Frank, the law "becomes a par-

21 See Neil Duxbury, "Jerome Frank and the Legacy of Legal Realism," Journal of Law and Society (UK) 18 (1991), 176-177 (brief biographical sketch).

22 Jerome Frank, Law and the Modern Mind (New York: Brentano's, 1930), 6.

23 Jean Piaget was a Swiss psychologist who worked with Alfred Binet in testing the intelligence of children and wrote a number of books on childhood development. Frank acknowledged that, in Law and the Modern Mind, he "relied chiefly upon Piaget, an eclectic psychologist, who has done an immense amount of first-hand work with children.” Ibid., 326 note 1 (notes to Part One, Chapter II); see also ibid., 69n.* (citing three articles by Piaget).

24 See ibid., 13-16. To be fair, Frank asserted that he was providing only a "partial explanation" of the phenomenon he described, and included an appendix offering fourteen other "possible additional explanations of the basic legal myth." Ibid., xiii, 13, 263 (Appendix I). On the other hand, Frank's writing style was both provocative and repetitive, so it was easy for the reader to form the impression that the "partial explanation" was dominant, if not exclusive. See Robert Glennon, The Iconoclast as Reformer: Jerome Frank's Impact on American Law (Ithaca, NY: Cornell University Press, 1985), 48. 
tial substitute for the Father-as-Infallible-Judge." 25 Caught between the uncertainty attendant to the practice of law-with its "changing realities," which require "recognition of novel circumstances, tentativeness, and adaptation" - and the desire to "achieve certainty, rigidity, security, uniformity" (the result of "unconscious longing for the re-creation of a child's world stimulated in all men ... by the very nature of law"), the lawyer essentially becomes a "professional rationalizer[ ]." ${ }^{26}$ Frank, needless to say, objected to this state of affairs. In response, he urged the legal profession, basically, to grow up and embrace uncertainty, rather than attempt to avoid it or conceal it. ${ }^{27}$

Frank also focused his analysis on the understanding of rules and judicial decisions in the legal system. Frank chose Joseph Henry Beale, an accomplished Harvard Law School professor (and former student of Dean Langdell), to personify the conventional formalist view of what constitutes law. ${ }^{28}$ According to Frank, Beale defined law as "(1) [s]tatutes, (2) rules and (3) 'the general body of principles accepted as the fundamental principles of jurisprudence.'”29 Moreover, for Beale,

[t]his third element is "the one most important feature of law: that is ... a body of scientific principle. ... Law, therefore, is made in part by the legislature; in part it rests upon precedent; and in great part it consists in a homogeneous, scientific, and all-embracing body of principle [which is] ... "truly law" even "though no court has lent its sanction to many of [its] principles." 30

Frank railed against this view. The law as portrayed by Beale bore no resemblance to the law experienced by practicing lawyers. "Particular judgments of particular controversies are only vaguely predictable," observed Frank. ${ }^{31}$ Furthermore, he noted that "[d]ecisions in the courts of any given

25 Frank, Law and the Modern Mind, at 18; see also ibid., 20 ("Hence the basic legal myth that law is, or can be made, unwavering, fixed and settled.").

26 Ibid., 30-31.

27 Ibid., 17-18 (discussing the career of William James, who made a "sudden shift from panic fear of insecurity to a deep enthusiastic bliss in the absence of security [which] marked for James the advent of emotional adulthood").

28 Ibid., 48 (Beale is “one of America's most influential legal writers from whom, at Harvard Law School, many of the leading lawyers of this country have received valued instruction. Beale's opinion, which is representative of the conventional doctrine, commands attention.").

29 Ibid., 51.

30 Ibid., 51-52.

31 Ibid., 53. 
state ... vary." 32 Borrowing from Holmes, Frank offered his own definition of the law "from the point of view of the average man," which he described as "a decision of a court with respect to [any particular set of] facts so far as that decision affects that particular person." 33 Thus far, Frank's critique was familiar, even, in its own way, conventional. Holmes, after all, already had observed that "a legal duty so called is nothing but a prediction that if a man does or omits certain things he will be made to suffer in this or that way by judgment of the court." 34

Frank extended this criticism, however, drawing upon the lessons he had learned from the emerging discipline of psychiatry. Focusing on the judge, Frank challenged the conventional view that "the judge begins with some rule or principle of law as his premise, applies this premise to the facts, and thus arrives at his decision." 35 Nonsense, insisted Frank. Instead, he argued that "[j]udicial judgments, like other judgments, doubtless, in most cases, are worked out backward from conclusions tentatively formulated." ${ }^{6}$ Frank elaborated upon his challenge to the conventional view of judicial decisionmaking. He quoted favorably the description of Judge Joseph C. Hutcheson, Jr. that judging consisted of arriving at a "hunch," and then providing the "ratiocination" for the decision in the written opinion. ${ }^{37}$ Frank recognized the consequences of his argument: "Whatever produces the judge's hunches makes the law." 38 Although he acknowledged that the "rules and principles of law" were part of the stimuli that produced the judge's hunches, Frank nevertheless insisted that there were many "complicated" and "hidden" factors that influenced the individual judge. ${ }^{39}$

Frank did not confine his critique to the vagaries of the judge's personality. In addition to the fact that judges made decisions based upon hunches, Frank argued, the judicial fact-finding process was full of opportunity for error. ${ }^{40}$ Even honest witnesses made mistakes when they testified, and the risk for error increased due to the possibility that the judge or jury did

32 Ibid.

33 Ibid., 46.

34 Holmes, "The Path of the Law," 458.

35 Frank, Law and the Modern Mind, 101.

36 Ibid.

37 Ibid., 103-104.

38 Ibid., 104; see also ibid., 133 (noting that "the personality of the judge is the pivotal factor").

39 Ibid., 104-106.

40 Ibid., 110-111. Frank elaborated: If [the judge's] final decision is based upon a hunch and that hunch is a function of the "facts," then of course what [the 
not correctly understand the testimony or became distracted while listening to the witness. ${ }^{41}$

One should not exaggerate the novelty of Frank's insights—even Frank acknowledged that much of his book merely debunked myths about the legal system told by lawyers and judges for the general audience. In part, it was the vehemence of his assault on the legal system that made his claims bold and provocative, especially for the era in which they were written. Frank effectively held up a mirror to the legal system, and reflected back something akin to the abyss. At the time, it was difficult to conceive of a more direct assault on the inductive logic of formalism. The operating legal principles, said to be discoverable in the law books and reported cases in the library, did not resolve cases, and did not provide definitive guidance on the outcome of a legal dispute. Frank did not shy away from the implications of his argument: If the administration of justice was idiosyncratic, it could not be said that litigants received equal treatment in the legal system..$^{42}$

Frank did not provide a programmatic solution to improve the judicial system he described in Law and the Modern Mind. He agreed with reformers that psychology could provide further insights into how individual judges decided cases, but acknowledged that such efforts depended upon the willingness of the "judges to engage in searching self-analysis." 43 However, he did not expect most judges to be willing to engage in such selfanalysis. ${ }^{44}$ Still, the best lawyers and judges can do, according to Frank, is grow up. This meant embracing change, accepting uncertainty, and liberating civilization from "father-governance." 45

Law and the Modern Mind received a broad but divided reception. Although critics agreed that Frank's book was "provocative," 46 not every reviewer employed that description with favor. A number of prominent pro-

judge], as a fallible witness of what went on in his courtroom, ... believes to be the "facts," will often be of controlling importance. So that the judge's innumerable unique traits, dispositions and habits often get in their work in shaping his decisions not only in his determination of what he thinks fair or just with reference to a given set of facts, but in the very processes by which he becomes convinced what those facts are. Ibid.

41 Ibid., 106-111.

42 See ibid., 111-112.

43 Ibid., 113-114.

44 See ibid., 116-117.

45 See ibid., 243-252.

46 See Felix S. Cohen, “Among Recent Books,” ABA Journal 17 (1931), 111 (book review) (located in Jerome Frank Papers, Box 128 Folder 3) (describing Law and 
fessors and writers praised Law and the Modern Mind. ${ }^{47}$ More revealing than the positive reviews, however, were the critical ones. Initially, Law and the Modern Mind was challenged for its method, or its science. These reviews questioned whether Frank had accurately described the operation of the legal system, whether he had properly weighed the value of certainty in a legal system, and whether he reasonably relied upon psychiatry as an explanatory extra-legal discipline.

For example, Mortimer Adler, a University of Chicago philosopher who embraced foundational principles, ${ }^{48}$ sounded a sharp note in his assessment of Law and the Modern Mind in the Columbia Law Review in 1931. Frank's book offended Adler from start to finish. According to Adler, Law and the Modern Mind was a lawyer's brief rather than a philosopher's discussion, demonstrating flaws in logic and argument, and erring even in its understanding of psychiatry. ${ }^{49}$ Adler dismissed Frank as "an extreme nominalist" for whom "nothing exists except particulars, and words are merely their names." 50 Adler's assault, though sweeping, centered on the shortcomings of Law and the Modern Mind as a work of philosophy.

What is worth noting about the reception of Law and the Modern Mind immediately after its publication is that the debate over the book revolved

the Modern Mind as "the most provocative stimulus to thinking on fundamental legal problems ... in the Anglo-American literature of jurisprudence since Dean Pound's Spirit of the Common Law"); see also Charles E. Clark, "Jerome N. Frank," Yale Law Journal 66 (1957), 817 (stating that "Law and the Modern Mind fell like a bomb on the legal world").

47 See Karl Llewellyn, "Legal Illusion," Columbia Law Review 31 (1931), 82 ("This book excites. ... It is well-nigh unique in attempting exploration of emotional drives and genetic psychology for their contribution to our understanding of the ways of law."); Walter Wheeler Cook, "Legal Logic," Columbia Law Review 31 (1931), 108 (defending Law and the Modern Mind against attack by Mortimer Adler); see also Thurman W. Arnold, "Law and Men," Saturday Review of Literature (1931), 644 (located in Jerome Frank Papers, Box 128 Folder 3). Earlier in 1931, Arnold wrote a letter to Frank in which he observed that Mortimer Adlerin his review in the Columbia Law Review- "appears to throw big words at you like a comedian throws custard pies." Letter from Thurman Arnold to Jerome Frank (Jan. 15, 1931) (located in Jerome Frank Papers, Box 4 Folder 108). Arnold returned to this image in his article for the Saturday Review of Literature. See also Max Radin, "Giving Away the Legal Show," New York Harald Tribune, Dec. 21, 1930, Books 5 (located in Jerome Frank Papers, Box 128 Folder 3).

48 See Purcell, The Crisis of Democratic Theory, 3 (noting that Adler believed "that human reason could discover certain immutable metaphysical principles that explained the true nature of reality").

49 See Mortimer J. Adler, "Legal Certainty,” Columbia Law Review 31 (1931), 91.

50 Ibid., 98. 
around the soundness of its science. This inquiry did not focus on the political implications associated with an arbitrary judicial system. Frank's book did not, in 1931, pose a threat outside the academy. As the decade progressed, this would change, and Frank and the legal realists would come under fire for the political values associated with their jurisprudence. On the eve of and during World War II, those critics could be sharp: Legal realism, they charged, permitted—indeed, was synonymous with-fascism.

Indeed, by the end of the 1930s, virtually no academic discussion could occur without reference to the political developments in Europe and elsewhere. An increasingly popular attack on legal realism was that it permitted fascism. This development is reflected, in part, in the Julius Rosenthal Lectures Professor Fuller gave at Northwestern University in 1940. ${ }^{51}$

The development of Fuller's views on legal realism illustrate the turn of the jurisprudential tide against legal realism. Initially, Fuller appreciated the anti-formalist insights offered by the legal realists, though he insisted upon a more purposive and value-laden understanding of the law and the legal system through which it developed.52 As the 1930s progressed, however, Fuller joined the chorus of natural law scholars criticizing legal realism. In 1940, Fuller's book, The Law in Quest of Itself (which collected his lectures at Northwestern), sharply and specifically condemned the legal philosophies of positivism (and its related successor, legal realism) for contributing to the emergence of fascist governments in Germany and Spain.

In his second speech, Fuller addressed legal realism. He viewed legal realism as a modern form of positivism-one that sought "to anchor itself in some datum of nature, which considers that the law's quest of itself can end successfully only if it terminates in some tangible external reality." ${ }^{33}$ In their studies of judicial behavior, according to Fuller, the legal realists modified positivism, focusing on what judges do rather than on what they

51 Fuller's opportunity to give the Rosenthal lectures came shortly after he arrived at Harvard Law School in 1939 for a stint as a vising professor from Duke Law School. Robert S. Summers, Lon L. Fuller (Stanford, CA: Stanford University Press, 1984), 5-6. Fuller subsequently received a permanent appointment at Harvard, retired in 1972, and died in 1978. Ibid., 7, 13.

52 See Lon Fuller, "American Legal Realism," University of Pennsylvania Law Review 82 (1934), 429.

53 Fuller, The Law in Quest of Itself, 47; see also ibid., 55 ("[T]he psychology involved in the realist view is largely indigenous to the soil of legal positivism.”). Fuller cited Frank's Law and the Modern Mind as one of "the most important expositions of the realist conception of law.” Ibid., 52 note 11. 
say. ${ }^{54}$ Indeed, Fuller argued, the legal realists insisted upon "a sharp line between the rules that judges act on and those they talk about ... a field [of] pure judicial behavior" that corresponded to Austin's sovereign..$^{55}$

In his final lecture, Fuller connected his critique of positivism to current political developments. "We live in a period when major readjustments in our economic and social order have become necessary," he wrote. ${ }^{56}$

It would seem that the present is a time when our social structure requires to be held together by a cement firmer than that supplied by the abstract principle of respect for law as such. If Renan was right in assuming that men have the capacity for developing the illusions necessary for their survival, we ought to be seeing a revival of natural law. ${ }^{57}$

Under the philosophy of positivism, Fuller continued, "[s]ince power rests ultimately on the acquiescence of the governed, the most logical principle of government is that of majority rule, since this offers the broadest base for the order set up." ${ }^{58}$ Fuller was dismayed by this view of democracy: It did not provide for justice, and did not come "closer to the inner essence of things than the will of any particular individual." ${ }^{59}$ Moreover, he argued that this "purely negative ... conception of democracy"-based upon only the exercise of power by the majority—has "played an important part ... in bringing Germany and Spain to the disasters which engulfed those countries." 60

With respect to Germany, Fuller elaborated:

It was only this conception [of democracy] which could mislead men into believing that the power relations inside a society could be radically displaced by the mere will of a numerical majority, or that a social and economic revolution could be accomplished through a democratic control unsustained by any common faith or program. It was this conception which lulled men into the dangerous dream that a kind of political euthanasia of vested interests would be possible. In the rude awakening which followed this dream there was demonstrated, at least in Germany, not only the futility of the dream itself, but

54 See ibid., 52.

55 Ibid., 59.

56 Ibid., 115.

57 Ibid., 116.

58 Ibid.

59 Ibid., 121.

60 Ibid., 122. 
the inability of repressive violence to fill the void left by a defaulting principle of majority rule, for the purported counter-revolution of Nazism has in many cases only increased the tempo and violence of the disintegrative forces from which it claimed to be rescuing Germany. ${ }^{61}$

As world events brought the United States closer to, and then into, World War II, critics of legal realism compared the realists to the emerging fascist governments in Europe, in particular the Nazi regime in Germany. By divorcing law from morality, insisting upon retaining an air of scientific detachment, and denying the significance of legal rules, the realists appeared to embrace the notion that power-and only power-was relevant to and necessary for governance. Compared to claims made by other natural law scholars in the early 1940s, Fuller's critique seemed positively mild. In 1942, for example, Father Francis E. Lucey of Georgetown wrote: "Realism is being tried out today in Germany and Russia." ${ }^{2} \mathrm{He}$ argued, "The Jurisprudence of these countries is the 'Is' Instrumentalism or Pragmatism of the Realist. What works is good. They exclude principles and morals and God from the picture of law, national and international." ${ }^{3}$ Lucey continued: "For Holmes and the realist[, man] is a sort of superior animal. ... If man is only an animal, Realism is correct, Holmes was correct, Hitler is correct." 64

\section{World War II, the Nuremberg Trials, the Decline of Legal Realism, and the Revival of Natural Law Theory}

After World War II, attention turned to development of a new political order. Immediately after the war, some in the United States desired-and even were optimistic about the prospect of-a new world order governed by international law. The idea of human rights, for example, reflected this

61 Ibid.

62 Francis E. Lucey, "Natural Law and American Legal Realism: Their Respective Contributions to a Theory of Law in a Democratic Society," Georgetown Law Journal 30 (1942), 523.

63 Ibid.; see also Purcell, The Crisis of Democratic Theory: 164-172 (describing the attack by Catholic natural law scholars on legal realism).

64 Lucey, "Natural Law and American Legal Realism," 531; see also Purcell, The Crisis of Democratic Theory, 157-158 (quoting Robert Hutchins, former Yale Law School Dean, as saying, "[t]here is little to choose between the doctrine I learned in an American law school ... and that which Hitler proclaims"). 
sentiment. ${ }^{65}$ A working definition of human rights, from the perspective of the United States in 1945, was the idea that individuals in a foreign state have "universal, objective human rights ... regardless of the content of [that foreign state's] positive law." 66 This idea of human rights reflected natural law principles.

However, the vindication of human rights potentially conflicted with another fundamental legal principle: the due process protection against retroactive laws. Although there was (and is) not an absolute protection against retroactive lawmaking, the principle of due process protects individuals against liability—and even more strongly, against criminal punishment-for conduct that was neither illegal nor prohibited when it occurred. This concern about retroactive lawmaking reflected positivist principles. In the post-war period, the protection against retroactive lawmaking was subordinated to the human rights principle that some rights exist independent of the state's laws, and that some conduct is wrong-and may be judged as such —even if that conduct is not prohibited by law. ${ }^{67}$

The clash between the natural law notion of human rights and the positivist concern about retroactive lawmaking is reflected in the writings of both Frank and Fuller after World War II. Fuller discussed it in a debate about the validity of Nazi laws after the war, while Frank addressed this conflict in the context of the Nuremberg trials. ${ }^{68} \mathrm{In}$ an article published in Collier's in 1945, Frank defended the necessity of the trials for the sake of world peace. In this discussion, he specifically noted the "moral effect" of the trials, and enlisted this value in the cause of establishing a new world order. ${ }^{69}$ That natural law principles seemed to triumph is just one indication of their revival during this period.

65 See Primus, “A Brooding Omnipresence," 429-430.

66 Ibid., 430.

67 See ibid., 431.

68 Herbert Wechsler acknowledged the retroactivity charge but insisted that, in the context of law and politics of international relations, the defendants had received sufficient prior notice that they could be punished criminally for their conduct. See Herbert Wechsler, "The Issues of the Nuremberg Trial," Political Science Quarterly 62 (1947), 11, reprinted in Herbert Wechsler, Principles, Politics and Fundamental Law (Cambridge, MA: Harvard University Press, 1961), 153-155.

69 Jerome Frank, "War Crimes: Punishment for Today-Precedent for Tomorrow," Collier's, Oct. 13, 1945, 73. Frank elaborated: [T] he principal purpose of the trials is not the regeneration or the re-education of Germany. Far more important is the moral effect on other peoples ... With the dropping of the first atomic bomb on August 6, 1945, lasting world peace became the immediate concern of everybody on this planet, including the hard-headed practical realists. For the maintenance 
The Nuremberg trials were an extraordinary event, and important to United States's post-war foreign policy. It therefore is not entirely surprising that Frank would set aside his skepticism of judges and the judicial process in endorsing the efforts of Justice Jackson and the goals of the war crimes trials. Nevertheless, it is worth noting that his discussion of the Nuremberg trials did not even resonate with, much less mention, his usual criticisms of the trial process - the childish quest for certainty, the limits inherent in the judicial fact-finding process, the intuitive quality of judging. Frank's silence is even more notable given the novelty of the tribunal, as well as its task - to pass legal judgment on the conduct of individuals pertaining to international affairs and war.

The Collier's article is important also because it is one of the earliest indications of Frank's acknowledgment-if not embrace-of natural law principles. ${ }^{70}$ In his post-war books, Frank responded to criticism that his emphasis on "fact skepticism" indicated a lack of commitment to valuesby acknowledging basic natural law values and by emphasizing that his work aimed to improve fairness in the judicial system (and was intended to promote democratic government). ${ }^{71}$ To be sure, Frank did not abandon his earlier views and become a disciple of natural law. He continued to address the limits of the trial process and to insist that psychiatry remained crucial to understanding the individual decisions made by trial judges. Natural law was not, and could not be, "practically meaningful," because "[n]atural [l]aw aims at justice and at moderate certainty ... in the more or less abstract, generalized human formulations of what men may or may not lawfully do[, and] ... judicial justice must be justice ... in the concrete —in the courts' decisions of the numerous particular individual cases." 72

of such peace a vigorous, organized world order is imperative. The Nuremberg trial signalizes the emergence of such a world order ... To the prisoners' dock are called men once mighty_among others, a Reich Minister Goering, a Foreign Minister Von Ribbentrop, a Labor Minister Ley, a Field Marshall Keitel. Their very presence dramatically affirms that a robust world morality is alive at this moment, that a world conscience is on its way to becoming an accepted world custom. Ibid.

70 See Duxbury, "Jerome Frank and the Legacy of Legal Realism," 194, 203 note 130 ("In the 1940s Frank 'found' natural law."). The Collier's article is the earliest writing by Frank cited in Duxbury's discussion of Frank and natural law. See ibid.

71 See ibid., 185-86, 194-96.

72 Jerome Frank, Law and the Modern Mind (6th ed. 1949), xviii. Frank elaborated on these points in his other book published in 1949, Courts on Trial: Myth and Reality in American Justice (Princeton, NJ: Princeton University Press, 1949), 346-374. 
Frank was more vehement about his concern for democracy in the postwar era. Even before the Cold War dashed hopes for a world order regulated by a regime of international law, there was anxiety in the United States about the fate of democracy in the post-war period. Some of this anxiety stemmed from the example of Nazi Germany, which revealed the nightmare possible through tyranny of the majority. Frank's post-war writings consistently noted and addressed this concern for democracy. In the sixth printing of Law and the Modern Mind, published in 1949, Frank emphasized that his efforts to demystify the trial court process were motivated by a desire to ensure fair trials, which were vital to democracy. ${ }^{73}$ It may be argued that Frank's concern for democracy, acknowledgment of natural law, and proposals for reforming the judicial system resulted from his own efforts to "grow up" since he wrote Law and the Modern Mind in 1930. Yet, it is also the case that these developments in Frank's jurisprudence reflected the revival of natural law in the United States-a shift that itself resulted from and reflected concerns about totalitarian governments, in particular Nazi Germany.

The issue of retroactivity, briefly taken up by Frank in his Collier's article, is at the heart of the debate between Professors Fuller and Hart. ${ }^{74}$ Fuller's 1958 debate with English philosopher H.L.A. Hart over positivism in the Harvard Law Review is perhaps the most famous jurisprudential exchange of the twentieth century. ${ }^{75}$ As I will discuss, the specter of Nazi Germany informed-even framed-the exchange. Central to the debate was a disagreement over judicial treatment of laws enacted and enforced while the Nazi government was in power. Although neither Fuller nor Hart specifically discussed the Nuremberg trials, the debate over retroactive invalidation of Nazi laws paralleled the retroactivity issue raised by the war crimes prosecutions.

73 See Frank, Law and the Modern Mind, supra note 73, xix.

74 See supra note 70 and accompanying text.

75 See H. L. A. Hart, "Positivism and the Separation of Law and Morals," Harvard Law Review 71 (1958), 593; and Lon L. Fuller, "Positivism and Fidelity to Law-A Reply to Professor Hart," Harald Law Review 71 (1958), 630. This debate has been described as "the most interesting and illuminating exchange of views on basic issues of legal theory to appear in English in [the twentieth] century." See Summers, Lon L. Fuller, 10. Many commentators have acknowledged both the quality as well as the significance of the exchange. See, e.g., Carl Landauer, "Deliberating Speed: Totalitarian Anxieties and Postwar Legal Thought," Yale Journal of Law \& the Humanities 12 (2000), 171, 217 (referring to Fuller's "famous 1958 exchange with H.L.A. Hart in the Harvard Law Review"). 
The specific question addressed in the exchange was the validity of laws that had been enacted by the Nazi government and had been invoked to perpetrate wrongful acts. In German legal proceedings after World War II, could litigants defend their actions on the grounds that they were authorized by Nazi laws? This question paralleled the retroactivity debate over the Nuremberg prosecution: In the post-war German cases, the courts relied upon natural law principles to invalidate Nazi laws, and thereby denied litigants the protection claimed by positive Nazi law. In the Nuremberg trials, the prosecution effectively relied upon natural law principles to retroactively criminalize conduct that previously had not been illegal under international law. In both cases, natural law principles were cited to justify prosecution and punishment of individuals who committed legally permissible but morally reprehensible acts while the Nazi government was in power. The specter of Nazi Germany framed the debate: Hart vigorously denied the connection between positivism and Nazism. ${ }^{76}$ Fuller-citing the history of positivism in German jurisprudence-argued to the contrary. ${ }^{77}$ Fuller asserted that "if German jurisprudence had concerned itself more with the inner morality of law, it would not have been necessary" to confront the legal question of whether to invalidate "the more outrageous Nazi statutes." 78

In presenting his general case for positivism, Hart argued for the separation of law and morals through an account of the utilitarian philosophy of Bentham and Austin. He connected positivism with the political reforms they championed. Bentham and Austin "were not," Hart wrote, "dry analysts fiddling with verbal distinctions while cities burned, but were the vanguard of a movement which laboured with passionate intensity and much success to bring about a better society and better laws." ${ }^{.79}$ When Hart turned to criticism of positivism based on the example of Nazi Germany, he sought to downplay the argument by describing it as "less an intellectual argument ... than a passionate appeal supported not by detailed reason-

76 See Hart, "Positivism and the Separation of Law and Morals," 617-618. The literature on this debate is extensive, and continues today. See Primus, "A Brooding Omnipresence," 432-433 and note 61.

77 See Fuller, "Positivism and Fidelity to Law," 657-661.

78 Ibid., 659-660.

79 Hart, "Positivism and the Separation of Law and Morals," 596. 
ing but by reminders of a terrible experience." ${ }^{80}$ Nevertheless, Hart seemed to be on the defensive as he began his presentation. ${ }^{81}$

Hart then addressed the retroactivity issue. After World War II, the German courts had to decide cases in which "local war criminals, spies, and informers under the Nazi regime were punished." 82 The cases presented a dilemma: The persons punished after the war had been prosecuted for actions authorized by laws enacted during the Nazi regime; now, however, those laws did not provide a defense because they were immoral and therefore were not valid. For example, as Hart summarized:

In 1944 a woman, wishing to be rid of her husband, denounced him to the authorities for insulting remarks he had made about Hitler while home on leave from the German army. The wife was under no legal duty to report his acts, though what he had said was apparently in violation of statutes making it illegal to make statements detrimental to the government of the Third Reich or to impair by any means the military defense of the German people. The husband was arrested and ... was sent to the front. In 1949 the wife was prosecuted [pursuant to an 1871 law that had been in force since its enactment] in a West German court for an offense which we would describe as illegally depriving a person of his freedom.... The wife pleaded that her husband's imprisonment was pursuant to the Nazi statutes and hence that she had committed no crime. ${ }^{83}$

Ultimately, the wife was found guilty of depriving her husband of his freedom. The German appellate court invalidated the Nazi law cited by the wife as "contrary to the sound conscience and sense of justice of all decent human beings." 84

Although, as Hart noted, "[m]any of us might applaud the objective" of the court's decision, Hart was disturbed by the result, because the court had found that a validly enacted law did not, in fact, have the force of

80 Ibid., 615.

81 See ibid., 616. Hart acknowledged that among the post-war critics of positivism were "German thinkers who lived through the Nazi regime and reflected upon its evil manifestations in the legal system," citing Gustav Radbruch, who had "shared the 'postivist' doctrine until the Nazi tyranny" but essentially recanted those views after the war. Ibid.

82 Ibid., 618.

83 Ibid., 618-619.

84 Ibid., 619. 
law. ${ }^{85}$ The better solution, Hart argued, would have been for the legislature to pass "a frankly retrospective law" that at least would have acknowledged that "in punishing the woman a choice had to be made between two evils, that of leaving her unpunished and that of sacrificing a very precious principle of morality endorsed by most legal systems." ${ }^{86}$ Positivism demanded candor, and Hart believed it was necessary to expressly resolve the moral dilemma between delivering justice in the woman's case and observing the duty to obey the law by passing a new law to supersede the prior Nazi laws.

Fuller did not believe that the case presented such a dilemma. In a more detailed response, he analyzed the Nazi statutes relied upon by the wife, and argued that they did not provide a valid defense because they did not have the quality of law. Fuller argued that one of the statutes, enacted in 1934, had been applied in an overbroad manner, while the other statute, enacted in 1938, was a "legislative monstrosity" that permitted "uncontrolled administrative discretion." ${ }^{87}$ Whether a court or an individual was required to follow such laws (simply because of their status as laws) or to instead "do what we think is right and decent" 88 did not create a dilemma for Fuller. "I do not think it is unfair to the positivistic philosophy to say that it never gives any coherent meaning to the moral obligation of fidelity to law," Fuller concluded. ${ }^{89}$ Although Fuller also endorsed the enactment of a new statute to invalidate the earlier laws, he justified that choice on entirely different grounds: The adoption of a new law would "symboliz[e] a sharp break with the past," and help usher in a new, lawful regime.90 Although Fuller did not discuss the Nuremberg trials, his remarks endorsed the natural law justifications for the Nuremberg trials.

Finally, it is worth noting an indication of the rise of natural law and corresponding decline of positivism was Hart's concession that, under certain extreme circumstances, a law may be so immoral as to not require obedience. ${ }^{91}$ Hart's admission that the content of a law could justify disobedience tainted the purity of his case for positivism-a damaging conces-

85 Ibid.

86 Ibid.

87 Fuller, "Positivism and Fidelity to Law," 652-654.

88 Ibid., 656.

89 Ibid.

90 Ibid., 661.

91 Hart, "Positivism and the Separation of Law and Morals," 616-617; see also Landauer, "Deliberating Speed," 217-218 (discussing Hart's concession). 
sion when defending a legal philosophy that championed adherence to the law.

\section{The Nuremberg Trials and the Development of Legal Process Theory}

Natural law theory sought to prevent the reoccurrence of a totalitarian regime such as Nazi Germany by expressly incorporating moral considerations into the evaluation of positive laws. Legal process represented an alternative response to the concerns about totalitarianism (including facism, as exemplified by Nazi Germany). As Professor William Wiecek has explained, legal process proponents viewed "the legal system as ... both a collection of substantive rules and as 'a structure of decision-making processes." 92 They believed that substantive rules "rest[ed] ultimately on conflicting rules best reconciled by the political branches, not the courts," while " $t \mathrm{t}] \mathrm{he}$ processes of law [were] the lawyer's domain, where legal expertise is both most needed and most readily justified." ${ }^{93}$ Instead of approving natural law reasoning by courts-that is, encouraging the consideration of morality in the act of judging - process jurisprudence cabined judges. By confining policy disputes to political branches and confining judges to a particular institutional role, process jurisprudence aimed to promote democracy. In what follows, I will discuss the influence of the Nuremberg trials on legal process theory through the example of Herbert Wechsler, a leading proponent of the theory, focusing on his famous Neutral Principles article. ${ }^{94}$

Wechsler enjoyed an extraordinarily distinguished career as both a law professor and practicing attorney. He is the only author discussed in this Article who was directly involved in the Nuremberg trials. During World War II, Wechsler served as Assistant Attorney General in charge of the War Division. At the end of the war, Wechsler helped shape the nature and scope of the war crimes prosecution efforts, and subsequently served as an

92 William M. Wiecek, "American Jurisprudence after the War: "Reason Called Law," Tulsa Law Review 37 (2002), 857, 868.

93 Ibid., 868. See also Donald A. Dripps, "Justice Harlan on Criminal Procedure: Two Cheers for the Legal Process School," Ohio State Journal of Criminal Law 3 (2005), 126 ("Policy choices, on the legal process account, ought to be made by institutions best equipped for the kind of questions at hand.").

94 See Herbert Wechsler, "Toward Neutral Principles of Constitutional Law," Harvard Law Review 73 (1959), 1. 
advisor to the judicial tribunal at Nuremberg. ${ }^{95}$ After his service in Nuremberg, Wechsler wrote an article defending the legitimacy of the prosecution and the tribunal. ${ }^{96}$

Wechsler's experience in Nuremberg influenced his writings on legal philosophy, including his famous 1958 Oliver Wendell Holmes lecture at Harvard. That lecture became the basis for his most well-known article, Toward Neutral Principles of Constitutional Law. ${ }^{97}$ That article generated great interest-and still merits scholarly attention-because of its criticism of the Supreme Court's reasoning in Brown v. Board of Education ${ }^{98}$ (though not its result, which Wechsler supported). ${ }^{99}$ As Wechsler has stated, there is a connection between his service at Nuremberg and his ideas set out in Neutral Principles.

There are at least three aspects of the Nuremberg trials that are relevant to the legal process school, in particular, Wechsler's views. First, process theorists distinguished law from politics. Wechsler, for example, sounded this note early in his Neutral Principles article. ${ }^{100} \mathrm{He}$ did not deny that principles have a role in politics, but the role of principle in the political arena was limited to that of a "manipulative tool." With courts, "something else is called for," and Wechsler insisted "that the main constituent of the judicial process is precisely that it must be genuinely principled, resting with respect to every step that is involved in reaching judgment on analysis and

95 See Norman Silber and Geoffrey Miller, "Toward 'Neutral Principles' in the Law: Selections from the Oral History of Herbert Wechsler," Columbia Law Review 93 (1993), 854, 856-857.

96 See Herbert Wechsler, "The Issues of the Nuremberg Trial," Political Science Quarterly 62 (1947), reprinted in Wechsler, Principles, Politics and Fundamental Law (1961), 138-157.

97 See Wechsler, "Toward Neutral Principles". In the constitutional law literature, the "Neutral Principles" article has been extensively discussed and widely cited. See, e.g., Cass R. Sunstein, "Neutrality in Constitutional Law (with Special Reference to Pornography, Abortion, and Surrogacy)," Columbia Law Review (1992), 5 (commending the "Neutral Principles" article as " $t]$ he most celebrated essay in all of constitutional law"); Fred R. Shapiro, "The Most-Cited Law Review Articles," California Law Review 73 (1985), 1540, 1549 (tabulating Neutral Principles as the second most heavily cited law review article).

98347 U.S. 483 (1954).

99 See infra notes 111, 114-115 and accompanying text.

100 See Wechsler, "Toward Neutral Principles," 12. Wechsler elaborated: "The man who simply lets his judgment turn on the immediate result may not, however, realize that his position implies that the courts are free to function as a naked power organ, that it is an empty affirmation to regard them, as ambivalently he so often does, as courts of law." Ibid. 
reasons quite transcending the immediate result that is achieved."101 Wechlser elaborated on this point, articulating a central principle of the legal process school:

[M] ust [courts] not decide on grounds of adequate neutrality and generality, tested not only by the instant application but by others that the principles imply? Is it not the very essence of judicial method to insist upon attending to such other cases, preferably those involving an opposing interest, in evaluating any principle avowed?102

Wechsler previously had addressed the distinction between law and politics in his article defending the legitimacy of the Nuremberg tribunal's work. ${ }^{103}$ The strongest criticism of the Nuremberg trials was that "victor's justice" was administered at the trials, and that the trials were merely political affairs in which justice was neither sought nor administered. Wechsler acknowledged this criticism but nevertheless insisted that the legality of the proceedings-in which a formal indictment was issued, counsel was provided, and trial procedures were followed-ensured a more fair process and outcome than the prevailing political solution at the time, which was summary execution.

Second, although Wechsler did not specifically mention this point in his article defending the tribunal, it is the case that the judges at Nuremberg were required to articulate the reasons for their judgment. In an interview at the end of his career, Wechsler stated that "the principal function of Nuremberg and supplementary trials was not to administer punishment, but to influence its withholding, its postponement, while passions cooled, and to give reason a chance to be operative in determining who deserved to be punished." ${ }^{04}$ The tribunal's reasoned explanation was not only superior to the politically popular alternative of summary execution, it also required a more reasoned decision than, for example, a jury verdict, which is made after secret deliberations and does not include an explanation. Wechsler adverted to this point in Neutral Principles when he noted that " $[\mathrm{a}] \mathrm{n}$ attack upon a judgment involves an assertion that a court should have decided otherwise than as it did. Is it not clear that the validity of an

101 Ibid., 15.

102 Ibid.

103 See Wechsler, "The Issues of the Nuremberg Trial," 153.

104 Silber \& Miller, supra note 96, at 913 (emphasis added). 
assertion of this kind depends upon assigning reasons that should have prevailed with the tribunal; and that any other reasons are irrelevant?" 105

Third, and finally, Wechsler insisted that the Nuremberg tribunal acted on-and attempted to articulate-a sufficiently neutral principle: the notion that the judging countries would agree and be subject to the same principles applied in their judgment of the Nazi defendants. ${ }^{106}$ In the interview noted above, Wechsler had the following exchange with the interviewers:

Was the neutral principles article in some ways the crystallization of your Nuremberg experience?

I wouldn't put it that way. On the other hand, what I wrote about Nuremberg-particularly my emphasis on the importance, in that undertaking, that we judge the enemy only by standards that we would apply to ourselves, be willing to apply to ourselves, and feel obliged to apply to ourselves-does represent an articulation of my belief in neutral principles back then. My whole effort in the Nuremberg thing, in which I think I was on the whole quite successful in strengthening the natural instinct of Judge Biddle to perform in this way, was to persuade him that in reaching judgment at Nuremberg, only standards that we felt confident we would be ready to apply to ourselves should prevail. Over and over again in my memoranda, this point would be made. ${ }^{107}$

\section{The Nuremberg Trials and Brown v. Board of Education}

In this Article, I have discussed the influence of the Nuremberg trials and the example of Nazi Germany only in the American legal academy, in relation to the decline of legal realism and the revival of natural law and emergence of legal process after World War II. Nuremberg and Nazi Germany also influenced the development of constitutional law during the post-war period as well. In taking this brief detour, I only want to note that with

105 Wechsler, "Toward Neutral Principles," 11; see also ibid., 19 (explaining that "[a] principled decision ... is one that rests on reasons with respect to all the issues in the case, reasons that in their generality and their neutrality transcend any immediate result that is involved," and that "[w]hen no sufficient reasons of this kind can be assigned for overturning value choices of the other branches of the Government or of a state, those choices must, of course, survive").

106 See Wechsler, "The Issues of the Nuremberg Trial," 156-157.

107 Silber and Miller, "Toward 'Neutral Principles'," 930. 
respect to Nuremberg and the example of Nazi Germany, the case law generally runs the same way as the academic discussion-in the direction of natural law foundationalism.

Richard Primus has attributed the Supreme Court's reversal of its position in the flag salute cases and the Japanese internment cases, and its decision in the Steel Seizure Case, to, in part, the concerns raised by the example of Nazi Germany. ${ }^{108}$ Perhaps the most compelling illustration of the influence of Nazi Germany on the Supreme Court is-as Primus and others have suggested-Brown v. Board of Education, ${ }^{109}$ in which the Court held that separate-but-equal public schools for African-American children violated the Constitution's Equal Protection Clause. ${ }^{110}$ The Nuremberg trials contributed to the growing sentiment against segregation that enabled the Court's decision in Brown. ${ }^{111}$

Brown represents the culmination of the developments previously discussed in this Article in a number of ways. First, a foundational principle in the post-war world was racial nondiscrimination. ${ }^{112}$ Brown enshrined that principle in the law of the United States, in a morality-based decision. ${ }^{113}$ Second, Brown launched an era of greater judicial activism. This development was necessary to guarantee the protection of foundational principles, and reflected the post-war rejection of the legal realist's demystified depiction of the judge.

108 See Primus, "A Brooding Omnipresence," 437-443.

109347 U.S. 483 (1954).

110 See Primus, “A Brooding Omnipresence," 437, 447-449; see also Constance Baker Motley, "The Historical Setting of Brown and Its Impact on the Supreme Court's Decision,” Fordham Law Review 9, 61 (1992), 12 (explaining that racial segregation during World War II embarrassed the United States, and helped bring about the Supreme Court's decision in Brown).

111 See William E. Nelson, "Brown v. Board of Education and the Jurisprudence of Legal Realism," Saint Louis University Law Journal 48 (2004), 795, 812. "The Nuremberg trials, as well as massive press coverage of Nazi atrocities, served to inform the wider American public of the horrors of the Third Reich's Final Solution. All of this would help make the kind of easy yet deep racial prejudice common earlier in the century far less respectable after the Second World War." Ibid. (quoting Robert J. Cottrol, Raymond T. Diamond, and Leland \& and Ware, "Brown v. Board of Education," Caste, Culture, and the Constitution 97 [2003]).

112 See Primus, "A Brooding Omnipresence," 447-448.

113 See Richard Fallon, "Legitimacy and the Constitution," Harvard Law Review 118 (2005), 1787, 1836 (arguing that Chief Justice Warren's "reasoning” in Brown "can easily be understood as advancing a substantially moral justification"). 
Third, Brown demonstrated that although legal realism no longer remained viable as an autonomous legal philosophy, it continued to influence American case law and jurisprudence. ${ }^{114}$ This influence is shown in Brown in the Court's reliance upon extra-legal materials to support its decision-specifically, the social science studies involving dolls cited by the Court, which demonstrated that racial segregation "generates a feeling of inferiority." 115

Finally, Brown figures prominently into Wechsler's Neutral Principles article-not because of the correctness of its result, but instead because of the shortcomings in its reasoning. Wechsler addressed Brown in connection with his consideration of the Court's contemporary equal protection cases. ${ }^{116}$ Before evaluating the decisions from a "neutral principles" perspective, Wechsler stated that the Court's equal protection decisionswhich invalidated "white primary" elections, ${ }^{117}$ judicial enforcement of restrictive covenants, ${ }^{118}$ and segregated schools ${ }^{119}$ — "have the best chance of making an enduring contribution to the quality of our society of any that I know in recent years." 120

Nevertheless, Wechsler found the reasoning in the Court's decisions inadequate. Specifically, Wechsler explained: "[T]he separate-but-equal for-

114 See Robert J. Cottrol, “Justice Advanced: Some Comments on William Nelson's Brown v. Board of Education and the Jurisprudence of Legal Realism," Saint Louis University Law Journal 48 (2004), 839, 850 ("Brown made a difference precisely because the advocates urging desegregation and the Court that accepted their arguments tapped into the changed mood and needs of the nation. In doing so they proved that they had learned the realist lesson well."); see also John Valery White, "Brown v. Board of Education and the Origins of the Activist Insecurity in Civil Rights Law," Ohio Northern University Law Review 28 (2002), 303, 306 (arguing that Brown "would give form and substance to realism, even as realism was being transformed").

115 Brown v. Board of Education, 347 U.S. 494 and note11. The Court stated: "Whatever may have been the extent of psychological knowledge at the time of Plessy $v$. Ferguson, this finding is amply supported by modern authority." Ibid. (citing psychology studies).

116 See Wechsler, "Toward Neutral Principles," 26.

117 Smith v. Allwright, 321 U.S. 649 (1944) (discussed in Wechsler, "Toward Neutral Principles,"26-27).

118 See, e.g., Shelley v. Kraemer, 334 U.S. 1 (1948) (discussed in Wechsler, "Toward Neutral Principles," at 26-27).

119 Brown v. Board of Education, 347 U.S. 649 (discussed in Wechsler, "Toward Neutral Principles," 31-34). Wechsler added that "for one of my persuasion," Brown "stirs the deepest conflict ... in testing the thesis I propose." Wechsler, "Toward Neutral Principles," 31.

120 Ibid., 27. 
mula was not overruled 'in form' but was held to have 'no place' in public education on the ground that segregated schools are 'inherently unequal,' with deleterious effects upon the colored children in implying their inferiority, effects which retard their educational and mental development."121 For Wechsler, the Court's judgment in Brown appeared to rest on the facts found by the district court - which provided an uncertain and contingent basis for the decision. ${ }^{122}$

Wechsler ultimately found it "hard to think the judgment [in Brown] really turned upon the facts" in the case, and located its foundational principle in "the view that racial segregation is, in principle, a denial of equality to the minority against whom it is directed; that is, the group that is not dominant politically and, therefore, does not make the choice involved." 123 However, this principle was not persuasive for Wechsler, because the problem posed by segregated schools was not discrimination, but denial of freedom of association. ${ }^{24}$ And here a sufficiently neutral principle became elusive, because "if the freedom of association is denied by segregation, integration forces an association upon those for whom it is unpleasant or repugnant." ${ }^{25}$ For Wechsler, the challenge posed by Brown was the inability to articulate "a basis in neutral principles" for the decision. ${ }^{126}$

\section{Conclusion}

The brevity of this article underscores its limits. I have addressed an enormously broad topic, and along the way I have tried to qualify my argument. Each author is as representative as a single author may be with respect to a particular legal philosophy. Of course, to articulate that notion is to demonstrate its limitations. Furthermore, it is difficult, if not impossible, to determine the exact causal relationship between a historical eventespecially one as complex as the Nuremberg trials-and its effect on a school of legal thought. Nevertheless, the trials both reflected and shaped

121 Ibid., 32.

122 The uncertainty derived from Wechsler's questions about what exactly the record in the district court demonstrated, while the contingency was due to the limited applicability to the next case of the findings by the district court in the Topeka, Kansas, case. Ibid., 32-33.

123 Ibid., 33.

124 See ibid., 33-34.

125 See ibid., 34.

126 Ibid. 
post-war concerns about the threat of totalitarianism and the future of democracy. These concerns, in turn, were reflected in the decline of legal realism, the revival of natural law, and the emergence of legal process philosophy.

As much as this article has emphasized historical context in understanding the jurisprudential developments it describes, it is worth noting the enduring contribution made by each author in legal thought. Frank's emphasis on the psychological need for certainty in Law and the Modern Mind to explain the function of the law and the operation of the legal system has not fared well over time. Nevertheless, his emphasis on the fact-finding process remains relevant today in, for example, the growth of clinical programs at law schools. Fuller's debate with Hart is a philosophical exchange for the ages, and Fuller's case for secular natural law theory continues to be taught today in jurisprudence classes. And of the many contributions to legal thought made by Wechsler, perhaps none is as well-known as his Neutral Principles article; its preoccupation with demarcating a principled line between law and politics informs the most pressing constitutional law questions of our time. 


\section{Section II:}

The Present-Day Impact of Nuremberg on

International Law 


\title{
The International Criminal Court and the Ethics of Selective Justice
}

Aaron Fichtelberg

\begin{abstract}
"Where law ends, discretion begins, and the exercise of discretion may mean either beneficence or tyranny, either justice or injustice, either reasonableness or arbitrariness."

-Kenneth Culp Davis ${ }^{1}$
\end{abstract}

One of the central concerns expressed by critics of the newly formed International Criminal Court (ICC) is that it will be unfairly selective in its choice of prosecutions. Some of these critics fear that it will target individuals from particularly unpopular nations while giving others a "free pass." Thus, American soldiers, politicians and diplomats, as representatives of the world's sole remaining superpower, will be singled out for prosecution, as would representatives of the perennially unpopular nation of Israel. Meanwhile other international criminals who are citizens of more barbarous states such as Syria, Myanmar, and Egypt would be free to commit whatever bestial acts they wish, without enduring any scrutiny by the court. Alternatively, critics from the third world fear that the court will be used selectively against smaller, weaker countries while leaders of countries like the U.S. and China will remain unmolested. For such critics, international courts represent a form of "victor's justice", representing the interests of wealthy, powerful states and demonizing those unable to stand up to it. To quote Hermann Goering, "The victor will always be the judge and the vanquished the accused." Despite their different interests, both the strong and the weak states on the global scene agree that the ICC's perceived selectivity could harm its legitimacy and, despite the popularity of the tribunal among human rights activists, many political experts express a great deal of wariness toward the court.

The nature of the contemporary international political order, coupled with the unique features of the ICC, only adds to these concerns. The fact that the court functions beyond the control of national political authori-

1 Discretionary Justice: A Preliminary Inquiry (Baton Rouge: Louisiana State University Press, 1969), 3. 
ties means that it would be very difficult for the American government to stop an unpleasant prosecution indefinitely. ${ }^{2}$ Such critics claim that the unique roles that the United States plays in global affairs adds to the problem. As the hegemon, the US is often given the responsibility of using its military power to maintain global peace and security in far-flung corners of the world, while simultaneously serving as a political foil for various national governments, leaving American soldiers, politicians, and diplomats in a uniquely vulnerable position. They must do things that are going to be politically unpopular, but they are the only people capable of doing what is required to stabilize the international order and prevent emerging threats (or so it is argued). This concern is magnified when we look at the relative unpopularity of America in the world and the not unrealistic expectation that international lawyers will try to "score points" in world opinion by "picking on" American servicemen. ${ }^{3}$ Given this (possible) unfairness, the argument goes, the United States should refrain from participating in the court and, according to the more extreme American opinion makers, actively seek to undermine the ICC as an international institution. ${ }^{4}$

One would be naive to believe that such critics of the ICC are solely concerned that it will become a "rogue institution." There is good reason to believe that some of these critics are not so much concerned with the ICC's fairness as with its potential impact on American hegemony. The fact that many American critics of the ICC speak with concern solely with regards to the court's possible jurisdiction over American citizens, is already grounds for suspicion. However, in this essay, I will take these concerns at face value as genuine assertions about danger that such trials pose. Additionally, I will assume that the court may single out individuals for prosecution while ignoring other suspects who are just as likely guilty of comparable crimes. These, it seems to me are not unlikely possibilities. Nor is it

2 For one particularly strong formulation of this see John R. Bolton, "The Risks and Weaknesses of the International Criminal Court from America's Perspective," Law \& Contemporary Problems 64 (Winter 2001), 167.

3 Kristafer Ailslieger, "Why the United States Should be Wary of the International Criminal Court: Concerns over Sovereignty and Constitutional Guarantees," Washburn Law Journal 39.1 (Fall 1999), 80-105, 81.

4 There have been a number of significant efforts on the part of the US government to undermine the ICC's effectiveness. The two most notable are the so-called "Article 98 agreements" which prevent states from sending Americans to the court and the infamous American Servicemembers' Protection Act, which authorizes the President "to use all means necessary and appropriate" to free American citizens from the ICC. 
an unrealistic possibility in my estimation that international institutions such as the ICC (and more notorious institutions such as the WTO and the World Bank) may pose a threat to American hegemony or sovereignty. ${ }^{5}$ I will assume that these are true, in part, because the political issues related to the ICC do not interest me here. Rather, I'm interested in the moral issues surrounding the critics of the ICC. I'm not interested in the question "is the ICC bad for American power?" but rather, "is the ICC unfair when it prosecutes criminals selectively?”

Similar arguments were presented against the ICC's predecessors. Some complained that the post-World War II prosecutions in Nuremberg and Tokyo in the International Military Tribunal for Nuremberg (IMT) and the International Military Tribunal for the Far East (IMTFE) ignored the crimes committed by allied powers (such as the bombings of Dresden, Hiroshima, and Nagasaki and the massacre of Polish partisans in Katyn Forest) and focused exclusively on axis misdeeds. ${ }^{6}$ The tu quoque defense ("you did it too") was eliminated at the IMT, bolstering Goering's assertion that it was a court designed to try and convict the enemy and not a house of justice. Similarly, many in Serbia and Rwanda have complained about alleged anti-Serb and anti-Hutu biases in the two ad hoc tribunals that were developed by the United Nations Security Council in the wake of mass atrocities in their respective nations in the 1990s. ${ }^{7}$ Few Bosnian Muslims, Croats, or Kosovars have been prosecuted in international tribunals and no Tutsi was put on trial for criminal acts conducted during Rwanda's civil war. Thus while the ICC is a permanent court, which would presumably function differently from these ad hoc institutions, the legacy that the ICC has inherited is littered with examples of selectivity in prosecution, only further arousing suspicion about the court's ultimate role.

5 See Gary T. Dempsey, "Reasonable Doubt: The Case against the Proposed International Criminal Court," Cato Policy Analysis No. 311, http://www.cato.org/pubs/p as/pa-311.html.

6 For example, see Radhabinod Pal's dissenting opinion in the Tokyo Tribunal: "Judgment of the Hon'ble Mr. Justice Pal, Member from India," The Tokyo War Crimes Trial, ed. R. John Pritchard and Sonia Zaide, vol. 21 (New York: Garland Publishing, 1981).

7 " $[F]$ ar from revealing to Serbs the enormity of the crimes committed in their name, the trial has so far only served to reinforce the widespread Serbian prejudice that the tribunal is an anti-Serb kangaroo court and that Milosevic will emerge, as he has already declared, as the 'moral victor'." Tim Judah, "Serbia backs Milosevic in trial by TV: Alarm as former president gains the upper hand in war crimes tribunal," Observer News Pages, March 3, 2002: 23. 
The idea that selective prosecution is unjust, of course, is intuitively appealing. Normally, when a prosecutor is overzealous in carrying out her duties, or selects one individual as a "scapegoat" for crimes committed by others, many critics maintain that the prosecution is unfair and should not take place. Such critics quickly point to other equally egregious offenders who walk the streets unmolested as a sign of prosecutorial malfeasance. The assumption is that the individual who is being placed on trial is there for reasons other than her criminal conduct, and should be set free. Often they imply bigotry against an unpopular ethnic or religious group of which the defendant is a member. At a minimum, the prosecutor's selectivity is taken as a prima facie argument against the prosecution of a particular individual - a position that must be refuted if the prosecution is to go forward. After all, why should one person be punished for a crime when another who did the exact same thing is allowed to roam free?

In this paper, however, I will take a critical look at the concept of selective prosecution, and defend certain forms of selectivity in criminal justice. When we get past the simple principle that selective justice is not true justice and critically ask what it means for criminal justice to be selective and whether or not selective justice is always inherently wrong, the answers are more complicated than they may initially seem. Not all selective justice is unjust and not all selective justice ought to be rejected by ethical people. This, anyway, is what I will argue.

I will begin with a formal analysis of the concept of selective prosecution, outline what I take to be the significant ways that justice can be selective, and additionally, where selectivity can be justified and where it cannot. This will involve discussing selectivity along several different axes: justified and unjustified selectivity, doctrinal and applied selectivity, and procedural and substantive selectivity. Each of these distinctions, I will argue, reveal some of the ways that criminal justice institutions can be selective, only some of which are pejoratively so. Then I will examine the ICC to see whether, and to what extent, it shows features of selectivity in general, and unjustified selectivity in particular.

This project presents one significant problem, however: As of this writing, the ICC has yet to conduct any actual prosecutions. The court has indicted several people in different African conflicts, but only two people, Thomas Lubanga Dyilo and Germain Katanga of the Democratic Republic of Congo has stood before any ICC tribunal and these cases have not progressed far. This means that our answer to this question can only be tentative. There is a possibility that the prosecutor and the court could ignore its strict mandate and expand its powers, or it is possible that the court could shrink back from controversial cases and ignore crimes that clearly 
fall under the ICC's jurisdiction and mandate. The only material available for analysis at this point is the documentation surrounding the ICC such as the Rome Statute of the Court, its Rules of Procedure and Evidence, as well as the meeting notes of the Rome Conference, so these will constitute the material for scrutiny. Final judgments on a permanently functioning institution like the ICC are impossible as its performance will undoubtedly change over time as it develops and changes.

\section{The Concept of Selective Prosecution}

For most people, all violations of all criminal law ought to be punished in any decent, law-abiding society. Most believe that this is so regardless of which laws were violated, who violated them, and what the larger consequences of prosecution and punishment might be. Any failure to do so in any case would be anathema to the rule of law. However, such an evaluation of selective prosecution depends on a particular notion of how a criminal justice system functions. It understands criminal justice as a sort of bureaucratic machine that automatically responds to any infraction of a law with a prescribed and predetermined punishment. That is, any individual who violates a law faces a response from the criminal justice system: the police investigate the infraction, prosecutors bring it to trial, and if the accused is found guilty, she is appropriately punished for her infraction. Such a conception of the criminal justice system is a Weberian ${ }^{8}$ one and is captured in the symbolism of the courtroom, the blindness of lady justice, the robes of judges (denoting their non-human role), and the abstract language of the attorneys arguing a case ("your honor", "the accused," etc.) all conspire to make the actors in a criminal trial seem inhuman cogs in a "justice machine." In such a view of social organization the discretion practiced by individuals operating with the system appears as deviance from the political and judicial order. ${ }^{9}$

When understood through the discourse of justice and legitimacy, the objection to selectivity and the preference for governing through the application of an abstract rules takes on a different color. When expressed nor-

8 See Robert J. Holton and Bryan S. Turner, Max Weber on Economy and Society (New York: Routledge, 1991), 650-678.

9 As Weber puts it, under a bureaucracy, "The authority to give the commands required for the discharge of these duties is distributed in a stable way and is strictly delimited by rules concerning the coercive means, physical, sacerdotal, or otherwise, which may be placed at the disposal of officials." (Ibid, 650). 
matively, Weber's ideology of rule-based governance can be taken as the Aristotelian maxim, "Treat like cases alike." 10 That is to say, two cases that fall under the same rules must apply the rules similarly. To do otherwise is injustice. (Thus, rules do not only organize society, they also justify the choices made by social actors.) The "like cases" principle stands at the core of the rule of law for many theorists of both domestic and international justice. Franck, in particular, links this principle to international law and deduces institutional legitimacy from the equitable application of rules:

Coherence is a key factor in explaining why rules compel. A rule is coherent when its application treats like cases alike and when the rule relates in a principled fashion to other rules of the same system. Consistence requires that a rule, whatever its content, be applied uniformly in every 'similar' or 'applicable' instance. ${ }^{11}$

Failure to live up to such coherence means that an institution lacks fairness, and thus legitimacy, according to Franck, which, even more than enforcement can compel behavior. Thus the principle of justice is not only an objection to an individual prosecution, it underlies the legitimacy of political institutions and stands at the core of justice as fairness.

Of course, even a superficial examination of actual criminal justice systems reveals that this image does not fit even the most advanced, well organized, and ostensibly fair criminal justice systems. Every level of virtually all criminal justice systems is infused with a number of large spheres of discretion. Each stage of the system is packed with independent decision makers whose choices are not dictated by the mechanical application of a clearly defined set of rules - and often this is perfectly acceptable to everyone involved. A police officer may choose to pull over a speeding driver or let him go. If he pulls him over, he may opt to give the driver a citation or he may opt to let him go with a verbal warning. A prosecutor has virtually complete discretion in choosing who to prosecute, how to prosecute him, and when to prosecute him. During a trial, a jury may opt to nullify a case or a judge herself may prevent a case from going forward. Juries may decide a ruling on grounds that have nothing to do with the guilt or inno-

10 Aristotle, Nichomachean Ethics, Book V. As Hart puts it, "To say that the law against murder is justly applied is to say that it is impartially applied to all those and only those who are alike in having done what the law forbids; no prejudice has deflected the administrator from treating them 'equally." H.L.A. Hart, The Concept of Law (2 ${ }^{\text {nd }}$ ed.) (Oxford: Oxford University Press, 1996), 160.

11 Thomas Franck, Fairness in International Law and Institutions (Oxford: Oxford University Press, 1998), 38. 
cence of the accused, swayed by any number of factors that are not directly germane to the matter at hand. Finally, even if an individual is convicted, the range of judicial responses varies widely from incarceration to diversion to only a token punishment. All of these different responses to an infraction are perfectly legal and most are quite commonplace. Clearly, the image of the American criminal justice system as a blind machine processing lawbreakers is inadequate.

Moreover, when the independent judgment of criminal justice professionals is taken away and rulings are forced onto them by a set of formal rules, it is often damaging for the criminal justice system as well as for its perceived legitimacy. Judicial discretion, the ability of judges to pick a wide range of possible punishments for offenders has been taken away in a number of different circumstances by so-called "mandatory minimum" sentences required by laws. As one powerful critique of sentencing guidelines put it,

$[\mathrm{T}]$ he sentencing guidelines are based on the fundamental misconception about the administration of justice: the belief that just outcomes can be defined by a comprehensive code applicable in all circumstances, a code that yields a quantitative measure of justice more easily generated by a computer than by a human being. ${ }^{12}$

Similarly, prosecutorial discretion gives prosecutors the ability to handle crimes in ways that are appropriate to the facts at hand. Such laws require that judges give certain levels of punishment for certain infractions, independent of whether or not the individual "deserves" such punishment and ignores any sort of mitigating factors. Mandatory minimums have been established largely for drug offenses, but they also exist for sex and violence crimes. ${ }^{13}$ While treating like cases alike is a valid formal principle of justice, not all cases, and not all criminals, are alike. Each individual case has complexities and nuances that could never be captured by an abstract set of rules, no matter how detailed and elaborate they might be.

The fact that all extant criminal justice systems fall short of the idealized bureaucracy that Weber outlined is not, in and of itself, a bad thing. Behind the façade of an impartial "justice-machine" is the reality that the de-

12 Kate Stith and Jose A. Cabranes, Fear of Judging: Sentencing Guidelines in the Federal Courts (Chicago. IL: University of Chicago Press, 1998), 168-169. See also David Dolinko, "Justice in the Age of Sentencing Guidelines" (a review of Fear of Judging), Ethics 110.3 (April 2000), 563-585.

13 The Associated Press, "Sex-Offender Bill Is Passed by House," New York Times, July 26, 2006. 
cisions regarding life and death, freedom and incarceration are made by human beings with real commitments, experiences, genders, races, ages, etc. There is a sort of Sartrean bad faith involved in the assumption that judges have no human commitment to the justice that they dispense and that judges simply apply rules to facts. ${ }^{14}$ They are not empty vessels of law and justice, blindly dispensing it to the matter at hand but are human beings who bear a certain responsibility for their choices and their actions. Equally important, human beings in many cases may make better decisions if they allow personal experiences and hunches into the process.

Philosophical debates about the relation between rules and justice have a long and esteemed intellectual pedigree. Historically, Kant's categorical imperative, asserting that all rational beings must conform to universal laws and Aristotle's ideal that humans must always make moral decisions in human situations have been at odds. ${ }^{15}$ For Aristotle, it is not the blind application of rules that determines justice, but rather the practical wisdom (phronesis) of the decision maker. Justice is a human endeavor for Aristotle - not a mechanical operation. There is an equivalent to this in debate about the nature of normative reasoning in moral psychology. Kohlberg's emphasis on the manipulation and application of abstract principles as the highest form of moral reasoning conflicted with the "Care ethicists" (including most notably Carol Gilligan) emphasize personal experience and relationships as the centerpiece of a fully realized moral imagination. ${ }^{16}$ While, like all philosophical debates, these arguments have been conclusive, it is clear that the abstract application of generic normative rules to everybody in every situation is always the appropriate way to understand or construct normative systems. Thus even at the most abstract, philosophical level; there is no reason to believe that principles of justice require the universal application of norms.

Finally, the utility of the principle that "like cases ought to be treated alike" is not always clear when applied to actual cases. While as a formal principle or moral reasoning, this maxim is undoubtedly true and valid, it begs a number of deeper questions: What exactly makes one case "like" another one? What differences are relevant in the application of principles

14 Jean Paul Sartre, Being and Nothingness, trans. Hazel E. Barnes (New York: Washington Square Press, 1956), 86-116.

15 See Immanuel Kant, Critique of Practical Reason, and Aristotle, Nichomachean Ethics. For a more modern take on Aristotle and Kant see Alasdair Macintyre, After Virtue (Notre Dame, IN: Notre Dame University Press, 1984).

16 Carol Gilligan, In a Different Voice (Cambridge, MA: Harvard University Press, 1983). 
justice? The abstract principle that Franck et al rely upon for establishing the legitimacy of international institutions is weakened by its bare formalism, its inability to serve as a guide for existing political institutions. When we seek further detail about the nature of different cases as well as their similarities, it becomes effectively useless for understanding the discretionary application of justice. Clearly, more is required.

\section{Justifiable vs. Unjustifiable Selectivity in Criminal Justice}

Whether or not one wishes to take sides on these theoretical debates about ethics and the rule of law, it is undoubtedly true that all criminal justice systems are in some sense "selective," and that such selectivity may be necessary, morally justifiable and need not impugn the legitimacy of a trial or of a criminal justice system. So the next question is what kinds of selectivity are acceptable or unacceptable and why? Illegitimate selectivity would be selective prosecutions based on morally indefensible grounds. For example, prosecuting a person solely on the basis of their race would be indefensible. On the other hand, selective prosecution based on neutral or acceptable grounds can be legitimate. If two people are suspected of committing the same sort of crime, but one case would be difficult to prove and would require a great deal of resources, while the other would be a clear case and easily proven, one would be legitimate in prosecuting the latter and not the former. Similarly, if two cases presented themselves, while legally the same (say, both were murders), but one was brutal and vicious and the other less so, one would probably not feel that the two need be prosecuted in the same way. (The Roman army practiced decimation as punishment for cowardice on the battlefield: One soldier from a cowardly legion was selected at random for execution, while the others were only punished lightly. ${ }^{17}$ ) The question, then, is what, exactly determines the limits of just and unjust selectivity?

The distinction between legitimate and illegitimate selectivity depends on a further abstraction: defensible grounds for discrimination. That is to say that any selectivity or discrimination in criminal justice can only be excused by providing morally acceptable grounds for making such a distinction. This, unfortunately, is an abstraction that cannot be developed in detail here, simply because it would require a much deeper discussion about

17 For an example, see Seutonius, The Twelve Caesars, trans. Robert Graves (New York: Penguin Press, 1979), 57. 
similarities and differences in moral discourse. ${ }^{18}$ We can intuit some distinctions that we would accept and some we wouldn't: Distinctions based on race would not be a legitimate ground for treating different cases differently as would the wealth of the defendant. ${ }^{19}$ On the other hand, the age of defendants or their personal histories may be legitimate grounds for differing treatment. A prosecutor would probably be justified in not pursuing a juvenile offender for an offence or excusing an offender that may have been acting out in response to a personal tragedy. (Likewise, these factors could change the nature of the prosecution-lowering murder to manslaughter, for example.) Of course, these are debatable issues, but a successful argument would nonetheless validate the point that certain sorts of differences in defendants or in criminal cases can justify different treatments by a criminal justice system.

\section{Selectivity in Doctrine and Practice}

Criminal justice can be "selective" in a number of different ways and its best to clarify precisely where the law can be selective before we begin to make the case that the ICC is or is not selective, and in turn then whether or not this selectivity is justified. At risk of being pedantic and making an excess of distinctions, one can distinguish two major categories of selectivity: Doctrinal selectivity, and applied selectivity. Doctrinal selective entails selectivity on paper, that is, selectivity where a particular institution draws its normative lines. Doctrinal selectivity breaks down further into substantive and procedural selectivity, that is selectivity in how crimes are defined and distinguished, on one hand, and selectivity in terms of how suspected criminals are treated on the other. On the other hand, applied selectivity deals with the actual application of justice, that is, who is targeted by the criminal justice system and how they are actually treated once they enter it. In this section, I will elaborate on these points and, once we have sufficiently elaborated on the components of selective justice, we can then turn to the structure of the ICC in order to evaluate whether the selectivity applied there may be justified.

18 For one effort see Jeffrie G. Murphy, "Justifying Departures from Equal Treatment," The Journal of Philosophy 81.10 (October 1984), 587-593.

19 For an argument against the use of race as the basis for different treatment under the "like cases" principle see Richard Wasserstrom, "Rights, Human Rights, and Racial Discrimination,” The Journal of Philosophy 61.20 (1964), 638-639. 
As was previously mentioned, doctrinal selectivity can take two forms: substantive selectivity, and procedural selectivity. Substantive selectivity is selective in how an institution distinguishes between criminal and non-criminal behavior. If criminal behavior is defined in a way that makes unfair or indefensible distinction between two different behaviors, it is practicing substantive selectivity. Two normatively identical illegal acts are treated differently under the law (one is treated as a more serious crime than another) or the use of one is criminalized while the other is not are examples of substantive selectivity. Scholars and activists who complain about the sentencing disparities between the possession of powder cocaine and crack cocaine are making such an objection as are those who object to the criminalization of marijuana and the legality of alcohol. On the other hand, criminal justice can be procedurally selective in how it treats members of one group over another. If certain classes of criminals are provided rights that others are not, and these different forms of treatment lack justification, then they are a form of unjustified selectivity. A system that provided two forms of justice, one for the elites and one for the masses, or one for females and one for males would suffer from such a form of injustice. Doctrinal selectivity then requires that any differences in treatment either in conceptualizing crimes or processing criminals have some sort of normative justification.

The final sort of selectivity, applied selectivity, does not involve an institution's life on paper, but rather examines how real alleged offenders are actually treated by a criminal justice system in practice. As has already been argued, criminal justice systems are not immediately unjust because they do not seek to punish everyone who has violated criminal law-it is natural that criminal justice professionals will make some choices about who to prosecute and who to leave unmolested. Nonetheless, such practices may be considered an unjust selectivity if they are unacceptably carried out: The practical implementation of justice and the decision to overlook some lawbreakers and confront others, or the decision to treat two cases differently (say prosecuting one homicide as murder and another as manslaughter) may be unacceptable in certain situations. This sort of selectivity is much more complex than doctrinal selectivity precisely because it most often requires empirical evidence of wrongdoing over the long term. Because criminal justice is an ongoing process where prosecutors and law enforcement make decisions about complex events, some of which are ongoing, determining who should be prosecuted is never a simple affair. When we evaluate institutions, we can only evaluate their choices over the long term to see whether or not they have been unjustly selective in practice. Just as one swallow does not make a summer, one bad de- 
cision from prosecutors or judges does not entail a hopelessly corrupt, biased, or unjustly selective institution.

Many of the critics of international criminal justice refer to this sort of selectivity when they offer their critiques of the ICC. That is, they charge that international courts deliberately overlook the crimes of one group and focus on those of another. Charges that the Serbs were unfairly singled out by the ICTY, commonly asserted by Serbian sympathizers is one example of this. For example, as Diana Johnstone charged in The Nation magazine:

The I.C.T.Y., set up on an ad hoc basis by the U.N. Security Council, has neither the budget nor the control of the terrain necessary to serve up any more than an extremely selective justice, and the selection has from the start centered on the Bosnian Serb leadership, pre-judged as the guilty party. ${ }^{20}$

Johnstone's critique here deserves closer scrutiny: Whether or not the Bosnian Serb leadership were in fact guilty of the crimes with which they have charged is not the basis of the objection, nor (really) that their guilt has been prejudged ("guilt" is something only asserted after the conclusion of a criminal trial). Even if Mladic, Karadic, Tadic, and other Serbian criminals did commit the atrocities that they have been accused (and in Tadic's case, convicted), is immaterial for Johnstone's argument. Rather, her objection is that Serbs were singled out for prosecution (not conviction) while Bosnian Muslims and other participants in the war, not to mention President Clinton and other NATO leaders who ordered the bombings of Yugoslavia to stop ethnic cleansing in Kosovo, are unindicted by the court.

One final issue of selectivity involves the role of sovereignty and the right of states to deal with their own criminal problems in their own distinct way. That is, it is not unusual or unacceptable different states will prosecute different crimes in different ways or that they may prescribe different punishments for similar crimes. This, of course, is not improper in and of itself-different states may perceive threats differently or may have different local crime issues which require different responses from their national criminal justice system. A state with serious drug issues may wish to handle them differently, say, by punishing drug offenders more harshly than another society would. This is significant because an international system may punish crimes more or less harshly than a domestic court. Mass murder would be a potential candidate for capital punishment in the vast

20 Diana Johnstone, "Selective Justice in the Hague," The Nation, September 22, 1997: 16-21. 
majority of states that employ such a sanction, but not at the ICC. ${ }^{21}$ Moreover, the imprisonment prescribed by the ICC is likely to be different from that of states like Uganda or the Central African Republic-most prisoners will likely serve their time in states like Norway or Denmark (which of course does not mean that they would be in better conditions ${ }^{22}$ ). If the impartial application of justice entails treating "like cases alike", it is clear that at the international level, the existence of the ICC entails that international criminals will be treated differently from those prosecuted in a domestic trial. Thus, the justice provided for ICC defendants will be selective in the sense that they will be prosecuted under different rules and provided different punishments than those cases adjudicated in domestic forums.

\section{Does the ICC have Unjust Selectivity?}

Having provided at least a partial analysis of the formal properties of selective justice as well as the limits of legitimate selectivity, the next question is whether the ICC surpasses these limits. In this section I will examine the ICC through the selectivity matrix that I have just set out. Here, I will argue that there are a few cases where the ICC could be unjustifiably selective in practice, but most of these are likely to be exceptional ones and that, on the whole, on paper at least, there are few grounds for asserting that the ICC is illegitimate in its selectivity. While there are numerous avenues that one can take to explore selectivity at the ICC, but I will focus on the role of sovereignty (the limitation of the court's jurisdiction to states parties), the limitation of the jurisdiction to certain crimes (to "the most serious crimes of concern to the international community as a whole"), the role of the Security Council in the court's affairs, and the discretion of the ICC's prosecutor.

Sovereignty and Selectivity-Unlike domestic criminal justice systems, the ICC is constrained by state sovereignty. This is to say that the application of legal rules in international relations is constrained by the right of nations to do what they wish to their own citizens and the right of states to consent to the laws that bind them. This sovereignty is, of course, much more robust than in the domestic sphere. In regards to the ICC, sovereign

21 Article 77. For a criticism of the ICC on this point, see Dempsey, "Reasonable Doubt".

22 BBC News, “Taylor Complains about Hague Jail,” July 21, 2006, http://news.bbc.c o.uk/2/hi/africa/5203250.stm. 
states have numerous powers: They can choose to refer a case to the court and under the complementarity principle,,$^{23}$ they can assert jurisdiction over an indicted criminal and opt to prosecute him at home. Finally, a state can refuse to sign the ICC charter, meaning that they can deny the court jurisdiction over its nationals or over crimes that occur within their borders. The role of sovereignty in international affairs presents a serious possibility of doctrinal selective justice: the citizens some states will be subject to the court's jurisdiction while others, most notably the US, will not, regardless of whether they have committed putatively international crimes. Clearly, this seems to be an unjustified form of selectivity-national affiliation does not seem to be legitimate grounds for treating similar cases differently, and these states parties should be treated identically to non states parties.

While it is certainly true that the court's inability to prosecute citizens of non-states parties presents a challenge to those who want to defend the court, there are other issues that mitigate a conclusion that this practice is illegitimate. Simply put, there are certain other principles that trump the need for strict uniformity in the application of the law. Consistency and the rule of law must be balanced with principles of national sovereignty and the inherent right of states to refuse to be a party to the ICC. Underlying the principle of national sovereignty and justifying it is a deeper principle of collective self-determination - that groups of people should be able to choose how they wish to live together. For a state to refuse to become a party to the Rome Statute the ICC is a perfectly legitimate use of a group's self-determination and this legitimacy justifies the selectivity that sovereignty forces on to the ICC. For the court to assert jurisdiction over states that do not support the ICC and have not elected to become parties to the ICC is more troubling than cases where the ICC is precluded from investigating a case because the country is not a party to the Rome Treaty.

Thus, from this perspective, the selectivity problem arises not because the US, as a non-state party, is exempt from the ICC's jurisdiction. Rather, the more troubling cases are situations where the ICC at the request of the UN Security Council asserts its jurisdiction over states like Sudan, who are not parties to the ICC. ${ }^{24}$ Cases like this, where the Security Council overrides the prerogatives of a sovereign state, represent a more serious form of selective justice than cases where non-states parties are not prosecuted for violations of international criminal law. It is here that the potential for

23 See article: Article 17(1)(a).

24 United Nations Security Council Resolution 1593 (2005). 
abuse it highest. Of course, Sudan is not a state that represents the interests of its people (particularly those in Darfur), so to this extent Sudan's right to deny the jurisdiction of the ICC on principles of self-determination is sharply limited. While non-democratic states are sovereign according to standards of international law, their sovereignty cannot be premised upon the self-determination of peoples simply because the people do not determine themselves in these political environments. 25

Jurisdiction and Selectivity-The court's jurisdiction is limited in a number of significant ways that can have an effect on the prosecution of lawbreakers. The most general limitation on the court is spelled out in Article 5 (1) of the Rome Statute. Here the court's jurisdiction is restricted to, "The most serious crimes of concern to the international community as a whole" and not to every violation of international criminal law. This means that two individuals who commit roughly equivalent crimes may not face the same sort of justice-one would be a domestic matter for local courts and the other would be an international matter for the ICC. This further entails that different procedures and punishments will be meted out for some crimes and not for others. Is the "concern" of the international community grounds for choosing to treat some criminals differently than others or does this limitation denote an unjustifiably selective form of justice?

The answer depends largely on the meaning given to this ambiguous phrase as well as its moral significance. The term was initially presented to the court as a way to limit excessive prosecutions for relatively trivial violations of the law. Provided that it is used in such a format, there is no reason to believe that Article 5(1) poses any particular challenge to the legitimacy of the tribunal-it simply becomes one more aspect of the prosecutor's discretion (see below). Other sections of Part 2 of the Court's subject matter jurisdiction provide some clues on the meaning of Article 5(1): Article 7 limits "Crimes against humanity" to certain acts "when committed as part of a widespread and systematic attack directed against any civilian

25 A similar problem exists for states that are not democratic but nonetheless accept the jurisdiction of the court over their own nationals. The government does not represent the people and thus they cannot claim the authority of the people to join the ICC. Only democratic states that genuinely embody the will of the people can appeal to self-determination in order to accept or reject international legal obligations. At present, this is merely hypothetical, however, as all of the 100 states that are presently parties to the Rome Statute are democratic (albeit some are imperfectly so). (A list of states parties is available at: http://www.icc-cpi.int/sta tesparties.html.). 
population ${ }^{26 "}$ and Article 8 limits the court's jurisdiction over war crimes to those acts, "Committed as part of a plan or policy or as part of a largescale commission of such crimes. ${ }^{27}$ " Clearly, it is only under extraordinary circumstances that the ICC will act against international criminals and "ordinary" international crimes will not attract the attention of the court.

If these provisions are meant to give further specificity to Article 5(1) then the next question is whether or not these restrictive definitions of international crimes constitute morally relevant grounds for treating criminals prosecuted by the ICC different from other sorts of international lawbreakers. There are good reasons to think that this is the case. Both the definition of war crimes and that of crimes against humanity emphasize the scale of the crime: that they must be widespread and large-scale crimes. This means that the crimes prosecuted by the ICC will undoubtedly be particularly destructive, causing significantly more harm to life and property than common violations of international law. It is plausible to read the stipulation of Article 5(1) not as a call to the selective attention of the international community, but rather as a statement that only the most violent, destructive crimes ought to be prosecuted and punished by the court. Thus, the morally relevant concern about the ICC's jurisdiction is one of scale and degree-serious and widespread harm clearly merits different treatment from smaller sorts of crimes.

The Security Council-The third major sort of selectivity that one can point to in the construction of the court involves the role of the United Nations Security Council in the Court's functioning. Article 16 of the Rome Statute gives the Council the right to defer an investigation under its Chapter VII powers, which, "May be renewed by the Council under the same conditions." Formally, of course, granting such powers to the Council does not entail an unjustifiable form of selectivity. While the Council cannot stop a prosecution, it can indefinitely postpone one through continually renewing such resolutions. However, were the Council to do this indefinitely, particularly in a manner that seemed arbitrary or capricious, or most importantly lacked a normative justification (say, were it to continually pass resolutions to protect its own nationals while letting the prosecutions of citizens of other states continue), than it could lead to an unjust form of selectivity in practice. Were the Security Council to remain quiet and not check the prosecutor's power to conduct its own affairs, then there is no strong reason to be concerned about its influence.

26 Article 7(1).

27 Article 8(1). 
However, there are some important qualifications that need to be made before the Security Council's power to defer prosecutions is used to criticize the ICC. First, as a practical matter, it would be very difficult for the Council to continually protect an individual suspected of an international crime, simply because of the way that the statute has granted power to the court: The ICC Charter requires that these deferral resolutions be passed annually, which puts the onus on Council members to pass resolutions with the required nine votes of the Council members (and the concurrence of the six permanent members)..$^{28}$ The political costs of openly defying the ICC, particularly if the court develops a reputation as an impartial tribunal would be high, and would be likely to increase each year. (It is worth noting that the US Proposal at the Rome conference involved requiring Security Council approval to commence a prosecution as opposed to a positive resolution to-temporarily-prevent a prosecution.) Likewise, the prosecutions cannot be stopped by a veto from the Security Council's permanent members, meaning that they could not shield their own citizens from the ICC without the collusion of a number of other councilmembers. While it is true that Chapter VII of the UN Charter gives the Council the power to, "determine the existence of any threat to the peace, breach of the peace, or act of aggression and shall make recommendations, or decide what measures shall be taken... to maintain or restore international peace and security," this power is not absolute. It is limited by other parts of the UN Charter, such as Article 51 which limits states to

The Discretion of the Prosecutor-Probably more important than any other branch of the ICC for its good functioning is the prosecutor. Many complaints about selective justice at the ICC revolve around the powers given to the prosecutor, just as many complaints about its predecessor institutions lay blame at his or her feet-criticizing their choices to pursue one individual or group over others. Similarly, many of those who express fear that the ICC will become a reckless institution cite the discretion given to the prosecutor under the Rome Statute, which they charge empowers him to act as a rogue agent in international politics. As US Ambassador John Bolton states his objections:

What is at issue in the prosecutor is the power of law enforcement, a powerful and necessary element of executive power. Never before has the United States been asked to place any of that power outside the complete control of our national government. Our main concern 
should not be that the prosecutor will target for indictment the isolated U.S. soldier who violates our own laws and values, and his or her military training and doctrine, by allegedly committing a war crime. Instead, our main concern should be for our country's top civilian and military leaders, those responsible for our defense and foreign policy. They are the real potential targets of the ICC's politically unaccountable prosecutor.

... In European parliamentary systems... political checks [on the prosecutor] are either greatly attenuated or entirely absent, just as with the ICC's central structures, the court and prosecutor. They are accountable to no one. The prosecutor will answer to no superior executive power, elected or unelected. Nor is there any legislature anywhere in sight, elected or unelected, in the Rome Statute. The prosecutor, and his or her as yet uncreated investigating, arresting, and detaining apparatus, is answerable only to the court, and then only partially. The Europeans may be comfortable with such a system, but that is one reason why they are Europeans and we are not. ${ }^{29}$

Bolton's critique is both a normative and a political one. An unaccountable prosecutor can cause damage to US interests not only because he can label American actions "criminal", but likewise, because he may freely prosecute the leaders of unpopular nations like the US while facing few negative political consequences for these acts. Clearly, if Bolton's conception of the ICC prosecutor's powers were correct, there would be good reason to fear selective justice at the court.

It is certainly true that prosecutors have traditionally been given a large amount of discretion in choosing who to prosecute and the ICC is no exception to this general rule. He may choose to initiate a case that falls under the court's jurisdiction propio motu or he may likewise choose to decline to initiate an investigation based similarly on his own judgment. Further, the Rome Statute makes provision for the prosecutor to refrain from investigating a case when he thinks there are, "Substantial reasons to believe that an investigation would not serve the interests of justice 30 " broad and not well-understood language. ${ }^{31}$ However, his discretion it is also limited in some important ways. The prosecutor's discretion is

29 Bolton, "The Risks and Weaknesses".

30 Art. 53(1)(c).

31 For an in-depth discussion of this principle see Darryl Robinson, "Serving the Interests of Justice: Amnesties, Truth Commissions and the International Criminal Court," European Journal of International Law 14.3 (2003), 481-505. 
weighed down by the role of the Pre-Trial Chamber, which must authorize the commencement of an investigation by determining that there is a "reasonable basis" to proceed. ${ }^{32}$ Similarly, the pre-trial chamber must determine that court has jurisdiction over the case. Even the prosecutor's decision not to proceed with a prosecution is reviewable by the Chamber. ${ }^{33}$ Thus based on the construction of the prosecutor's authority in the Rome Statute, the likelihood of a rogue prosecutor arbitrary indicting offenders is not very high. ${ }^{34}$

However, in the US and other common law systems, there is an even wider degree of discretion than one finds at the ICC. In most jurisdictions, the prosecution, with the full blessing of law, has absolute discretion over who to prosecute. In most cases, prosecutors are elected by the public, giving them a clear incentive to prosecute criminals when there is strong public interest to do so. ${ }^{35}$ While none of these traditions explicitly authorize the prosecutor to refuse to pursue pursuing a case when they have reason to believe that a crime was committed on the basis of other normative principles, one can expect that, in practice, such values may guide domestic prosecutors (at least when they are high-minded). Nonetheless, there is nothing particularly unusual or odious about the ICC's formula for prosecutorial discretion-nothing, at least, that would authorize criticism for unjust selectivity. ${ }^{36}$

\section{Article 15.}

33 Article 53(3)(a).

34 For a more detailed study of prosecutorial discretion at the ICC see: Danner Allison Marston, "Enhancing the Legitimacy and Accountability of Prosecutorial Discretion at the International Criminal Court," American Journal of International Law 97 (2003), 510-552, and Luc Côté, "Reflections on the Exercise of Prosecutorial Discretion in International Criminal Law," Journal of International Criminal Justice 3 (2005), 162-186.

35 For a study of Prosecutorial discretion in the US system see: Bruce A. Green and Fred C. Zacharias, "Regulating Federal Prosecutors' Ethics," Vanderbilt Law Review 55 (2001), 381, 456.

36 Interestingly, a different criticism of the ICC Prosecutor assumes not that he will use the prosecution in a manner that results in unjust prosecution but rather that a prosecutor will not be selective enough:

Another key advantage of national level prosecutions is that they provide an appropriate context for the exercise of prosecutorial discretion. It is widely accepted that prosecutorial discretion is the sine que non of any civilized justice system. The essence of prosecutorial discretion is balancing the ability to obtain an indictment and conviction of a given person, who arguably has violated some law, with broader societal interests. At one level, it entails examining whether the alleged violation was willful and deliberate, whether the individual involved is a repeat 
Ultimately, however, the appropriate use of prosecutorial discretion is a matter of practical wisdom (Aristoelian phronesis) and the good judgment of prosecutors is essential to the formation of legitimate and well-run criminal justice institutions. The human factor cannot be eliminated from the implementation of criminal justice, whether domestic or international, regardless of how strictly the prosecutor's powers are controlled or guided by normative systems or political bodies. The political checks on prosecutors in American criminal justice that Bolton lionizes can just as easily be used as a tool of demagoguery or organized lynching by an ambitious prosecutor. Words on paper only restrict political entities if they are willing to perceive themselves (and others) as bound by these words. Thus, regardless of whether or not the Rome statute has constructed the prosecutor's powers appropriately, there is no reason to believe that this is enough to ensure that the ICC will not be unduly selective in its choice of prosecutions. This, ultimately, will depend on the ineliminable human factor.

\section{Conclusion}

We all know that the world is full of bad people who do bad things. We also know that the capacity of any criminal justice institutions to confront the vast array of evildoers that occupy the world is inevitably going to be limited. Not every crime, not even every serious crime can be prosecuted

offender, and whether "throwing the book" at him is the right thing to do. While it is not entirely implausible that an ICC or an ICTY prosecutor may be capable of exercising this form of prosecutorial discretion, the odds of this are not very good.

This reality has nothing to do with prosecutorial personnel staffing these international bodies - they can be the most honorable and the most decent individuals in the world - and has everything to do with institutional pressures and imperatives. The Framers of our Constitution would sadly chuckle at the presumption, oft-expressed by ICC supporters, that good persons can salvage flawed institutions. Our own experience with the independent counsel prosecutions shows what happens when even the most honorable individuals are put in a position where they staff a prosecutorial institution which is separate and distinct from the normal justice system and which exercises jurisdiction over a particular category of persons, i.e., senior government officials. This comparison is not far-fetched if we consider that prosecutors of the ICC and the ICTY see their reason d'etre as the prosecution of senior government officials of sovereign states who, in their view, have committed serious violations of international law and gotten away with it. (Rivkin, David B., Jr., "The Pitfalls of International Justice," Council on Foreign Relations Publication (2003)). 
by a criminal justice system, regardless of whether or not most of us expect it to. Justice is never perfect and it will always be selective in some form or another. If selective justice is inevitable sort then, the only question is whether or not the selectivity will be of a justifiable sort or rather be based on inexcusable criteria.

Perhaps nowhere else in the world are the limitations of criminal justice felt more strongly than at the international level. Unlike a domestic criminal court, the ICC must operate "under fire"-torn between the demands of states and non-state actors, NGOs, and global opinion and stripped of the other institutions (such as law enforcement agencies) that make domestic criminal justice effective. It is practically inevitable that one group or another will feel that they have been unfairly singled out for prosecution. It is likewise inevitable that alongside these prosecutions, others who committed similar crimes will be ignored by the court for a variety of reasons. If a case as clear as Nazi aggression in Europe was subject to charges of victor's justice, there is little hope that more complex conflicts would not engender similar feelings by those targeted by the court. Messy political conflicts, bereft of clear "good guys" and "bad guys" are the ones that are most likely to require intervention from the ICC and thus it is likely that the court will constantly attacked with charges of selective justice by partisans of one side or another.

As I have argued, there are no doctrinal grounds for believing that the ICC will be unjustifiably selective on any of the axes that I have set out here. Additionally, there are clear political restrictions that are designed prevent it from becoming a rogue institution, targeting criminals who are citizens of unpopular states like the U.S. and Israel. Of course, this does not mean that the ICC will necessarily be fair in its dealing with alleged international criminals. On paper it may be wisely designed, and there may be no prima facie reason to believe that it will be unfair in practice, but this is a far cry from saying that the court is fair or that it is unjustly selective in its prosecutions. There are numerous ways that the courts limitations could be overridden by overzealous or reckless jurists and the court could become the bogeyman that its American critics contend that it is. This, however, is unlikely and such developments are probably years in the future, if they ever were to appear. The distinction between the law "in books" and the law "in action" can only be made after the court has actually conducted prosecutions, after the law has been practiced, something that the ICC is only now beginning to get a taste of.

Finally, one should keep in mind that the legitimacy of an institution and its perceived legitimacy are two different things. The arguments that I have laid out here are normative arguments about principles of justice, not 
sociocultural claims about whether or not a group will see the ICC as being "unjust." Much of the concern about the ICC stems from the different perceptions of international institutions. Most people assume that there is the rule of law in domestic affairs and tend to discount contrary data as exceptions. On the other hand, despite the fact that much of global relations are well ordered, people assume that international relations are naturally in a state of anarchy and any evidence to the contrary is discounted as exceptions to this general rule. These differences are not institutional differences and do not stem from the different political structure, but rather they are cultural ones. With a few exceptions, Americans in particular, are taught to believe that, beyond the borders of modern nation state is a Hobbesian state of nature. This ideology will incline many in the US and abroad to view prosecutions by the ICC cynically or at least with a great deal of suspicion.

Skeptics towards the ICC maintain that an international court, without the backing of a traditional, national government cannot provide substantive justice, or put somewhat more abstractly, without a government, there cannot be the rule of law. However, the presence of a state does not guarantee that there will be the rule of law and the absence of a government does not mean that there cannot be justice and a well-ordered society. Many states have effective governments that are recognized by the international community, but nonetheless neither consistently nor fairly apply the law. Similarly, many communities and other forms of political association lack some of the crucial ingredients of a state, but nonetheless fairly and equitably apply rules. Nothing in the construction of the ICC precludes this possibility and given the level of commitment and professional responsibility of those who are helping construct the ICC (speaking from personal experience), there is ample reason to believe that it will be a wise and impartial arbiter of justice. As one important study of selectivity in international criminal justice has asserted:

Despite the ICC being open to certain criticisms of selectivity, and the questionable aspects of the Security Council's early reaction to the coming into force of the Rome Statute, these blemishes should not encourage forgetfulness about the extent to which the Court represents a dramatic leap forward in enforcement of international criminal law. The ICC is considerably less open to criticism on the basis of selectivity than previous Tribunals or many States' practice in this area. To de- 
mand perfection would be to demand the impossible, at the domestic or international level. ${ }^{37}$

37 Cryer, Robert, Prosecuting International Crimes: Selectivity and the International Criminal Law Regime (Cambridge, UK: Cambridge University Press, 2005), 228-229. 


\title{
The United Nations War Crimes Commission:
}

A Model for Complementarity today?

\author{
Dan Plesch and Leah Owen ${ }^{1}$
}

On 21 August 1942, President Franklin Delano Roosevelt issued a public statement on war crimes. In it, he warned the Axis powers that the United States would

make appropriate use of the information and evidence in respect to these barbaric crimes of the invaders, in Europe and Asia. It seems only fair that they should have this warning that the time will come when they shall have to stand in courts of law in the very countries which they are now oppressing and answer for their acts. ${ }^{2}$

Amidst growing public awareness of the scale of Nazi war crimes in occupied territory particularly the mass murder and persecution of Jews-there was growing political support for the idea that some form of formal justice or accountability measure must be implemented, and that this should occur in a domestic setting.

Roosevelt was by no means the only leader to publicly commit himself to postwar criminal justice (even if, as Kochavi suggests, this was more of a political ploy than a policy intent ${ }^{3}$ ). Winston Churchill declared shortly after, that Nazi war criminals would "have to stand up before tribunals in every land where their atrocities have been committed in order that an indelible warning may be given to future ages and that successive generations of men may say 'so perish all who do the like again"' 4 . In January 1942, a group of Allied States had signed a statement on "Punishment for War Crimes" that, in place of mere "acts of [vigilante] vengeance" and "in order to satisfy the sense of justice of the civilized world," called for "the punishment, through the channel of organised justice, of those guilty of or

1 This essay builds on a briefing paper by Dan Plesch, Leah Owen, Hanns Kendel, and Richard Wright; we are very grateful to Hanns Kendel and Richard Wright for their comments and suggestions in this essay.

2 US State Department Bulletin, August 22, 1942, 710.

3 Arieh Kochavi, Prelude to Nuremberg: Allied War Crimes Policy and the Question of Punishment (Chapel Hill: University of North Carolina Press, 2000), 33.

4 Ibid. 
responsible for these crimes, whether they have ordered them, perpetrated them or participated in them"5. This was reaffirmed by the Allied Moscow Declaration on Atrocities in October 1943, which-in addition to a list of war crimes the Nazis were accused of-put the Axis powers on notice that "most assuredly the three Allied powers will pursue them to the uttermost ends of the earth and will deliver them to their accusers in order that justice may be done"6.

Conventional wisdom holds that these sentiments found their eventual expression in the International Military Tribunals at Nuremberg and Tokyo. This is true, but an incomplete picture, and an incomplete realization of the values Roosevelt and others expressed. The Nuremberg, Subsequent Nuremberg, and Tokyo trials indicted 237 defendants in total, almost all major war criminals (political, business, and military leaders). With a few exceptions (such as during the Einsatzgruppen trial ${ }^{7}$ ), these represented a small fraction of the social infrastructure of war crimes, and of those personally involved in enacting campaigns of genocide, systematic terrorism, sexual violence, mistreatment of prisoners, and a range of other crimes.

This article will explore the other major institution of wartime and postwar international criminal justice-the United Nations War Crimes Commission (UNWCC). Between 1943 and 1948, the seventeen members of the UNWCC authorized 8,178 cases, involving over 36,000 accused, leading to at least 2,000 war crimes trials prosecuted in domestic courts. UNWCC members submitted indictments for "peer review" by other Allied states in a formal multilateral organization with diplomatic status staffed by their eminent jurists; if approved, they went on to enact prosecutions in their own courts. The accused ranged in rank from generals to private soldiers, in courts from China to Norway.

This chapter will provide a brief overview of the history of this organization and its operation. It draws upon the rapid growth of UNWCC scholarship (in particular the UNWCC Symposium and resultant special issue of the Criminal Law Forum ${ }^{8}$, Bergsmo et al.'s "Historical Origins of Inter-

5 The Inter-Allied Information Committee, Punishment for War Crimes: The Inter-Allied Declaration Signed at St. James' Palace London, (1942).

6 Washington, Government Printing Office, Foreign Relations 1943 (1), 769.

7 United Nations War Crimes Commission, Law Reports of Trials of War Criminals:

Volume IV (London: His Majesty's Stationery Office, 1948), 509-586.

8 Criminal Law Forum 25.1-2 (2014), 1-381. 


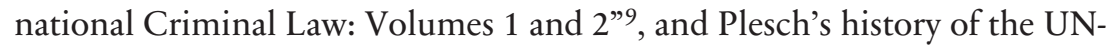
WCC $\left.^{10}\right)$. Having done so, we will then discuss the importance of the UNWCC's legacy and relevance today, especially in the light of the modern notion of "positive complementarity" and the "domestication" of international law. The Nuremberg Trials are highly influential on modern international criminal justice-indeed, Samantha Power has described how even the architecture and visual aesthetics of the International Criminal Tribunal for the Former Yugoslavia (ICTY) "seemed deliberately chosen to harken back to the UN tribunal's functional parent" ${ }^{11}$. What lessons could be learned from this other side of postwar international justice-is, as Carsten Stahn suggests, international justice in need of a "UNWCC 2.0"12?

\section{The History of the UNWCC}

As alluded to above, the UNWCC emerged from a growing awareness of the extent and scale of Axis war crimes, and a desire to seek some form of judicial reckoning and accountability for participants at every level. While the Nuremberg trials were largely a product of the major powers, they were often more hesitant about participating in the UNWCC's early stages -it was Asian and European states who played the major role, with governments-in-exile putting a high priority on seeking accountability for the atrocities their information-gathering networks sent evidence of back to them. Kerstin von Lingen notes that this "truly international network" emerged partly out of "an experience of political powerlessness ... these exiled politicians and experts keenly felt the low position their agendas and authority to punish war criminals held among their British hosts"13. To address this, a range of eminent European legal scholars (such as Egon

9 Morten Bergsmo, Wui Ling Cheah, and Ping Yi, Historical Origins of International Criminal Law: Volume 1-2 (Oslo: Torkel Opsahl Academic EPublisher, 2014).

10 Dan Plesch, Human Rights after Hitler: The Lost History of Prosecuting Axis War Crimes (Washington: Georgetown University Press, 2016).

11 Samantha Power, A Problem from Hell: America and the Age of Genocide (New York: Harper Perennial, 2002), 484.

12 Carsten Stahn, "Complementarity and Criminal Justice Ahead of their Time? The United Nations War Crimes Commission, Fact-Finding, and Evidence," Criminal Law Forum 25.2 (2013), 224.

13 Kerstin von Lingen, "Setting the Path for the UNWCC: The Representation of European Exile Governments on the London International Assembly and the Commission for Penal Reconstruction and Development," Criminal Law Forum 25.1 (2013), 74. 
Schwelb, later deputy director of the UN Human Rights Division, René Cassin, who received the Nobel Peace Prize for his work on the UN Declaration of Human Rights, and later Czechoslovak President Edvard Beneš) began to meet in the early 1940s, pooling institutional, legal, technical, and academic expertise in a series of conferences that laid much of the groundwork for the Commission. From an early stage, this concentration of legal expertise and the direct experience of conflict by European member states, shaped the organization as an institution particularly concerned with individual criminal responsibility for perpetrators across all levels, and one that would enact a joint Allied war crimes policy with well-defined national jurisdictions and evidence-sharing ${ }^{14}$. After some initial discussion, the UNWCC also decided to adopt a two-pronged approach to definitions of war crimes, opting to use the "Versailles list" of (which had been agreed by both the member states, as well as Germany and Japan $)^{15}$, as well as domestic penal codes. That these predated the Second World War helped resist nullem crimen defenses, the notion that war crimes could not be prosecuted if they had not been recognized as war crimes at the time. By the time it had begun to assess its first indictments in March 1944, the UNWCC had thus already developed a sophisticated set of organizational procedures,

This process of discussion and groundwork laying culminated in the establishment and official recognition of the UNWCC on 20 October 1943. Represented among its members were Australia, Belgium, Canada, the Republic of China, Czechoslovakia, Denmark, Ethiopia, France, Greece, India (as its own state), Luxembourg, the Netherlands, New Zealand, Norway, Poland, and Yugoslavia (both Royalist and, later, Socialist). The USSR had opted to pursue domestic war crimes separately, as attested elsewhere in this volume ${ }^{16}$; while there were some limited attempts at cooperation between the two processes, this was highlighted as a "greatly felt" loss by its members ${ }^{17}$.

14 Ibid., 64, 67-68.

15 UNWCC, Report of the Sub-Committee (December 2, 1943), 4. UNWCC, Information Concerning Human Rights Arising From Trials of War Criminals (New York: United Nations Economic and Social Council, 1948), 146-180, n1.

16 Marina Yu. Sorokina, "On the Way to Nuremberg: the Soviet Commission for the Investigation of Nazi War Crimes," Beth Griech-Polelle [ed.], The Nuremberg War Crimes Trial and its Consequences Today (Baden-Baden: Nomos Verlag, 2009), 21.

17 United Nations War Crimes Commission, National Offices Conference held at the Royal Courts of Justice, London, May $31^{\text {st }}$ to June $2^{\text {nd }}$, 1945 - Minutes and Documents, 35 . 
In addition to the role of continental European members, the Asian members of the Commission-China and India-also played leading roles in shaping the emerging organization. A founding and prominent member of the UNWCC, Chinese representatives had pointed out as early as January 1942 that China "subscribe[d] to principles of the declaration [on German atrocities] and intend[ed] when the time comes to apply the same principles to the Japanese occupying authorities in China"18; it had, after all, been involved in the Second Sino-Japanese War since 1937, and so in some ways had been involved in the conflict longer than the UNWCC's European members (a similar argument to that made by Ethiopia, surrounding its invasion and occupation by Italy in $1935^{19}$ ). This, together with Roosevelt's support for China as an emergent "great power" and its own desire to become more active in the international system ${ }^{20}$, led to it playing a key role in the Commission, particularly on issues such as the use of narcotics to subdue a population, and individual responsibility for the crime of aggression and crimes against peace ${ }^{21}$. After the foundation of the UNWCC, China established the Sub-Commission of the UNWCC in Chunking for the Far East on which member states were also represented, which was responsible for listing and organizing cases against over 3,000 Japanese defendants ${ }^{22}$. India, present on the Commission as an autonomous member even before its national independence, played a major role in developing the legal and organisational basis on which the Commission conducted many subsequent trials. Niharendu Dutt-Majumdar, the Indian representative, developed and drafted the notion of joint mili-

18 United States Department of State, Foreign relations of the United States diplomatic papers Volume 1: General; the British Commonwealth; the Far East (Washington: United States Government Printing Office, 1942), 45.

19 Ethiopian Government Press and Information Office, La Civilisation de l'Italie Fasciste en Ethiopie Vol. I \& II (Addis-Ababa: Berhanea Selam Printing Press, 1948).

20 Anja Bihler, "Late Republican China and the Development of International Criminal Law: China's Role in the United Nations War Crimes Commission in London and Chungking," Bergsmo et al. [eds.], Historical Origins of International Criminal Law, 513.

21 The Inter-Allied Information Committee, Punishment for War Crimes: The Inter-Allied Declaration Signed at St. James' Palace London 16 (1942); Wen Wei Lai, “China, the Chinese Representative, and the Use of International Law to Counter Japanese Acts of Aggression: China's Standpoint on UNWCC Jurisdiction," Criminal Law Forum 25.1 (2013), 121.

22 UNWCC, History of the United Nations War Crimes Commission and the Development of the Laws of War (London: HM Stationery Office, 1948), 514. 
tary tribunals used by the British at Belsen and the Americans at Dachau ${ }^{23}$, as well as successfully advocating for Ethiopian cases to be discussed by the UNWCC ${ }^{24}$. India also contributed significantly to the Commission's operation; out of a total of 1583 "units" of contribution to the budget, India contributed 80-the same as France, and more than Canada (60) or Australia and the Netherlands (30 each). Finally, while not a UNWCC member-operating largely under the auspices of the USA - the newly independent Philippines also handled a number of East Asian UNWCC cases, including the trial of Lt. General Shigenori Kuroda ${ }^{25}$.

From the beginning, the UNWCC had three specific duties-to investigate and record evidence of war crimes provided by member states; to determine whether such evidence amounted to a prima facie case that the state could prosecute; and to make recommendations to member governments concerning questions of law and procedure, to support trials ${ }^{26}$. It carried out these duties through the activities of three Committees, and a variety of supporting agencies and programs.

Committee I - "Facts and Evidence"-was tasked with gathering and collecting evidence from member states, and evaluating each charge leveled against accused war criminals (numbering about 36,000 individuals in total, in 8,178 indictments). While one of its first actions was to coordinate the establishment of national offices to handle war crimes investigations at a domestic level ${ }^{27}$, drawing on pre-existent legal structures and ministries of justice to avoid "re-inventing the wheel" 28 , its main function was its program of regular review. Each member state submitted cases to the UNWCC against alleged war criminals, whereupon - in weekly meetings -

23 UNWCC, Minutes of thirty-fourth Meeting held on October 3rd 1944, October 3, 1944, comment of Marcel de Baer, 5. UNWCC, Proposal for a United Nations Military Tribunal (Mr. Dutt's Proposal as Amended by a Drafting Committee), Doc. No. II/26, August 1, 1944; and Proposal for United Nations Military Tribunals, Doc. No. II/26/1, August 16, 1944.

24 UNWCC, Minutes of Meeting of Commission Held on Wednesday, September 24, 1947 at 3.00pm, September 24, 1947, 6.

25 Richard Goldstone and Adam Smith, International Judicial Institutions: The architecture of international justice at home and abroad (London: Routledge, 2015), 80.

26 UNWCC, History, 3.

27 UNWCC, Minutes of Tenth Meeting Held On 22nd February 1944, UNWCC, First Report of Committee I (Facts and Evidence) as Adopted by the Commission, C7 (1). Also see UNWCC, Minute No.60 Meeting Held On 10th May 1945, Minutes No. 66 Held On 20th June 1945, and Minutes and Documents of the United Nations War Crimes Commission National Offices Conference held at The Royal Courts of Justice, London, 31 May-2 June 1945.

28 UNWCC, History, 1948, I 2 I. 
the Committee analyzed the charges before it, determining whether there was a prima facie case that those listed should be categorized as accused war criminals, suspects, witnesses, or (in other cases) if there was insufficient proof or legal basis to charge them at all (instructing the National Offices to gather more evidence in such instances). In doing so, it critically assessed cases regarding their legal soundness, whether with regard to the degree of responsibility, the evidence identifying the suspect, and the question of whether military necessity rendered an act a war-crime or not $^{29}$. Committee I certainly did not "rubber stamp cases"-454 cases were withdrawn by member states, adjourned, or outright not accepted even after the Committee requested more information ${ }^{30}$

Thus, while not carrying out its own evidence gathering, the UNWCC extensively regulated the quality of charges submitted to it, and provided an important international imprimatur to individual countries' trial processes. Member states did not, in theory, have to take part (the USSR, for example, had for a variety of reasons elected to remain outside the UNWCC, and conducted its own trials), but participation in this process offered legitimation and approval from their peers in other member states and the nascent international framework of the United Nations. Throughout, the UNWCC supported the national offices in conducting their investigations, and also investigated some cases on its own by maintaining a small staff team that liaised with governments through the national offices ${ }^{31}$. As well as promoting better quality trials, it also offered greater domestic legitimacy for the process for other Allied states to have "signed off on" a given case in this manner.

Once indictments had been made, Committee I also conducted limited scrutiny of trials to ensure (or at least improve) their fairness. The UNWCC's report to ECOSOC on human rights discusses at length the human rights of accused war criminals, and how to resolve them where they conflicted with those of victims. ${ }^{32}$ Mark Ellis observes that while there were several issues with UNWCC-supported trials that would meet with criticism by today's trial standards (and indeed, met with criticism at the time), the "'basic elements of a fair trial' for the accused were regularly stressed

29 All of these objections to cases being approved-and more-can be found in one set of Committee I minutes alone. See UNWCC, Summary Minutes of the Meeting of Committee I held on 9th May, 1946, No. 60.

30 UNWCC, History, 1948, 513.

31 UNWCC, Internal Memo, April 18, 1945.

32 UNWCC, Information Concerning Human Rights, 1948, 103-109, 250-274. 
by the domestic systems"33. The UNWCC did not support "kangaroo courts", and worked to prevent these where possible, through case review, a 1945 conference to discuss and share policy and best practice ${ }^{34}$, and a scheme of support for countries who set up their own dedicated war crimes commissions. ${ }^{35}$

The work of Committee II - "Enforcement"-became largely folded in with CROWCASS, discussed in detail later. Rather than dealing with cases individually, it focused more on the creation of mechanisms for war crimes prosecution, whether offices in the territory of defeated enemies ${ }^{36}$, proposals for joint military tribunals ${ }^{37}$, and even a serious consideration of the establishment of an "international criminal court" to address atrocity crimes - in the $1940 \mathrm{~s}^{38}$. The first two of these, as well as the CROWCASS program, were successful, while the notion of an ICC would remain unfulfilled until the 1990s.

The main responsibility of Committee III - "Legal Affairs"-was to discuss "large questions of principle", and, more prosaically, to avoid bringing the UNWCC to a standstill while it had to refer legal problems to an external body. After all, as the History notes, it was a body of eminent jurists itself, and was thus capable of addressing these questions in its own right $^{39}$. After some initial disagreement regarding its constitution, it was established in February 1944 with jurists from a wide variety of countries represented among its ranks. Immediately after its establishment, it was highly busy-the History of the UNWCC describes it as "constantly being called on to examine and advise on a number of questions of substantive law when dealing with particular charges brought before it by National

33 Mark Ellis, "Assessing the Impact of the United Nations War Crimes Commission on the Principle of Complementarity and Fair Trial Standards," Criminal Law Forum 25.2 (2014), 207-222.

34 United Nations War Crimes Commission, National Offices Conference beld at the Royal Courts of Justice, London, May $31^{\text {st }}$ to June $2^{\text {nd }}$, 1945 - Minutes and Documents, 35.

35 UNWCC, History, 1948, I23.

36 UNWCC, Minutes of Twenty First Meeting, (June 6, 1944), 3, and the accompanying UNWCC Doc. C24, as well as UNWCC Minutes of Twenty Third Meeting (June 13, 1944), 3, and the accompanying UNWCC Doc. C30.

37 UNWCC, Minutes of $32^{\text {nd }}$ Meeting, (September 19, 1944). The Commission approved the adoption of a proposal for a United Nations War Crimes Court. (See the accompanying UNWCC Doc. C49, Doc. C50 and Doc. C58 Explanatory Memorandum.).

38 William Schabas, "The United Nations War Crimes Commission's Proposal For An International Criminal Court," Criminal Law Forum 25.1. (2014).

39 UNWCC, History, 1948, 125. 
Offices ... rang[ing] from the defense of 'military necessity' to the implication of 'usurpation of sovereignty" 40 . Other activities included developing more specific notions of war crimes, crimes against peace, and crimes against humanity ${ }^{41}$. Herbert Pell, the US representative, moved a resolution in March 1944 that provided an early definition of crimes against humanity as "crimes committed against stateless persons or against any persons because of their race or religion; such crimes are judiciable by the United Nations or their agencies as war crimes" 42 - this notably introduced the idea that domestic persecution, such as the Holocaust of the German Jews, could be addressed in an international major crimes framework, something that had been questionable before this, but seems to have informed later discussions of genocide, crimes against humanity, and human rights.

Also notable in Committee III's work is what was not debated in great deal, but rather seen as unremarkable. Water torture and part drowningan issue of intense relevance today-was charged ${ }^{43}$ and prosecuted (especially in UNWCC-supported American cases in the Pacific Theater $\left.{ }^{44}\right)$. The indictment of suspects for sexual violence was also routine-rape and forced prostitution went unremarked as the fourth and sixth crimes on the thirty-two-strong "Versailles list" of crimes listed by the UNWCC, rape featuring in all three draft lists of offences ${ }^{45} .151$ charges involving sexual violence were approved by Committee I. That Committee III did not see fit to discuss its thinking on sexual violence means we must infer exactly why this ready indictment of support for sexual and gender-based violence prosecutions was the case, but the presence of rape on the "Versailles list", and the use of domestic legal frameworks (which, though inadequate by modern standards, were nonetheless a lot better than overlooking war rape as a distasteful but "natural" phenomenon) seem to have helped. Indeed, once

40 Ibid., 124-127.

41 Ibid., 169-184.

42 UNWCC, Resolution moved by Mr. Pell on 16th March 1944.

43 UNWCC, Norwegian Charges against German War Criminals (Klötzer et al.), Registered No. 3193/N/G/55, Case No. 55, May 23, 1946.

44 See, for example, United States of America vs. Isamu Ishihara, Before the Military Commission by the Commanding General, United States Army Forces, China Theatre, among many others. Ishihara was a civilian interpreter, a fact that also helps illustrate the degree to which UNWCC-supported trial processes were concerned with fulsome prosecutions of even low-level perpetrators involved in war crimes.

45 UNWCC, Notes of Unofficial Meeting held at 2:30 p.m. on the 26th October, (October 26, 1943), n5. 
indictments developed into prosecutions, some (but not all) included a number of highly progressive elements, including focusing on lack of consent over the use of physical force, coercion as an element of forced prostitution, joint criminal responsibility and command responsibility for sexual violence, and respectful treatment of witnesses ${ }^{46}$.

Thus-whether through specific design or simply because it was seen as an obvious development of existing standards-Committee III and the UNWCC more broadly developed sophisticated and progressive legal responses to a range of issues. Much of this thinking fed into early international criminal law and human rights theory, through the UNWCC's 1948 report to the UN's Economic and Social Council (ECOSOC) ${ }^{47}$.

In addition to addressing case-specific and legal questions, the UNWCC also played an important role as an informational clearinghouse for member states, coordinating both its internal work, and its cooperation with other agencies.

The Research Office, for example, collated affidavits taken by resistance movements with primary documentation of war crimes (often, the Office built indictments on Nazi proclamations about the execution of Jews, communists, or partisans designed to intimidate others, condemning them with their own words) ${ }^{48}$, and compiled dossiers on specific Nazi leaders ${ }^{49}$ or the staff of specific camps ${ }^{50}$. Beginning in August 1944, it began compiling regular "Summaries of Information", providing backgrounds for particularly complex cases and "in their own words" accounts of Nazi policies involving possible war crimes ${ }^{51}$. These would then form an important part of the early planning of the Nuremberg trials; before the capitulation of Germany (and the resultant flood of documentation captured by the Allied armies), they provided an "indication of the objectives on which research might profitably be directed in the examination of the documents that were being brought to light in Germany", including "deportations for labor and forced labour ... concentration camp and Gestapo atrocities; exter-

46 Dan Plesch, Susana Sácouto, and Chante Lasco, "The Relevance of the United Nations War Crimes Commission to the Prosecution of Sexual and Gender-Based Crimes Today," Criminal Law Forum 25.1 (2014).

47 UNWCC, Information Concerning Human Rights, 1948.

48 UNWCC, History (1948), 165-166.

49 E.g. UNWCC, Research Office Document Series No. 6: Professor Rüdin's Racial Institute, (September 15, 1945).

50 UNWCC, Index to the Documents of the Research Office of the United Nations War Crimes Commission, (November 17, 1949), 2-19.

51 UNWCC, Research Office Summaries of Information 1-55 (September 1944 to December 1947). 
mination of the Jews; crimes against prisoners of war; Germanisation of conquered territories; crimes against foreign workers [and] medical experiments on prisoners" 52 . Even once the Nuremberg trials had begun, the Research Office fielded urgent document tracing requests and requests for information made by the Tribunal, and ensuring that much documentation of war crimes produced at Nuremberg that had no direct bearing on the trial was conveyed to relevant national authorities that were able to prosecute these crimes ${ }^{53}$.

In addition to this, the UNWCC was also closely involved in tracking and coordinating the disposition of war criminals who were wanted by the Allied nations, as well as those in custody. To prevent accused Nazis from slipping out of Allied custody, the Commission developed extensive liaisons and ties to the Supreme Headquarters Allied Expeditionary Force (SHAEF) towards the end of the war $^{54}$. One such institution was the Central Register of War Criminals and Security Suspects-CROWCASS. Recognizing the sheer scale of the problem, and the difficulties involved in handling suspects who might be in custody in one jurisdiction but wanted in another-CROWCASS published "wanted lists" of mid-high-ranking Nazi officials and those named in indictments, as well as lists of those currently in custody and witnesses, expediting and coordinating the transfer of suspects between nations so that they could face trial. This was highly effective; as Christopher Simpson notes, "although it was in operation for only three years [it] proved to be a singularly effective tool for locating tens of thousands of suspects", and was "probably the most extensive database on ... persons being sought for crimes against humanity ... ever created" 55 . It was instrumental in locating, charging, and convicting perpetrators involved in atrocities at Buchenwald, Mauthausen, and Dachau. CROWCASS was a flawed institution. The sheer scale of its activities often meant that accused war criminals did still slip through the cracks, as with Oskar Groening, the so-called "accountant of Auschwitz"56. In what was likely an early recognition of US covert programs like Operation Paperclip, Marian

52 UNWCC, History, 1948, 166.

53 Ibid., 166-168.

54 Ibid., 160.

55 Christopher Simpson, Blowback: America's Recruitment of Nazis and Its Effects on the Cold War (New York: Open Road Media, 2014), 66.

56 Owen Bowcott and Kate Connolly, How Nazi guard Oskar Gröning escaped justice in 1947 for crimes at Auschwitz, The Guardian, July 16 2015, https://www.the guardian.com/world/2015/jul/16/how-nazi-guard-oskar-groning-escaped-justice-in1947-for-crimes-at-auschwitz (accessed September 9, 2018). 
Muszkat, the Polish delegate to the Commission, complained to the UNWCC that the USA was flouting CROWCASS' standards of investigation, apprehension, and extradition by seeking out Germans with "knowledge in the field of complicated war techniques" (largely rocketry and advanced engineering) "not for trial, but for other purposes" 57 . In some cases, as Simpson relates, CROWCASS lists and processes were even directly used to identify ex-Nazis likely to be useful in the Cold War, rather than prosecute them ${ }^{58}$. Despite these flaws, however, the effort to prosecute war criminals was highly dependent on CROWCASS as a centralized registry, and the 85,000 wanted reports and 130,000 detention reports it had published by the time it ceased operating.

Despite these successes, the UNWCC, as with many post-conflict criminal justice initiatives, was not without its detractors. While many continental European countries were firm backers, factions in the US and UK governments had been much more reticent and would only grow more so after the war's end.

Even before the end of the war, for example, the US State Department had repeatedly obstructed the participation of Herbert Pell, a former congressman and US ambassador who had fervently advocated for the Commission. The Department saw the UNWCC as an overreach of US power and politically irrelevant. Through its influence on funding allocation, it eventually managed to have Pell withdrawn from the UNWCC ${ }^{59}$. While this did not end US participation - Pell's activism and subsequent outcry strongly committed the US to some form of postwar criminal justice - it limited support for the UNWCC in Washington. The beginning of the Cold War also complicated this - as discussed above, many accused Germans were seen as more useful as anti-Soviet assets than incarcerated for war crimes. On top of this, the newly inaugurated President Truman had been advised to reduce the costs of occupying Germany and bolster West Germany against its communist neighbors, both goals incompatible with ongoing support to the Commission ${ }^{60}$. Simpson describes how there was a sense of "hostility toward what might be called today legal 'activism' on the part of the Commission on the recognition of human rights [and] a

57 UNWCC, Letter from Marian Muszkat, Polish Delegate to the UNWCC, to Lord Wright, Chairman of the UNWCC, December 9, 1947, 4-6.

58 Simpson, Blowback, 67.

59 Graham Cox, "Seeking Justice for the Holocaust: Herbert C. Pell Versus the US State Department," Criminal Law Forum 25.1 (2014).

60 Christopher Simpson, "Shutting down the United Nations War Crimes Commission,” Criminal Law Forum 25.1 (2014), 38. 
tacit acknowledgement that aggressive, post-war prosecution of wartime Nazi quislings and collaborators posed political problems for Anglo-American strategy in Continental Europe and the Far East as the Cold War deepened" 61 . Papers from the British Foreign Office on the "winding-up of the UNWCC" (written in 1947, the year before this took place) clearly show the disdain many British diplomats felt for the Commission, criticizing its jurists as "legalistic and pedantic" 62 , its indictments as "frequently embarrassing and a nuisance to us", and its legal discussions (implicitly on issues such as crimes against humanity, and the way it was beginning to work with the UN to consolidate the precedents set up during the Nuremberg trials ${ }^{63}$ ) as dealing with matters "really not strictly their concern"64.

This hostility expressed itself in a number of forms, including withdrawals of and obstructions to funding, unilateral withdrawal from the system of extradition and deadlines on indictments, and the sealing and disposal of archives. Despite strongly worded objections and aggressively stepped up prisoner transfer requests by countries including France, Poland, and Czechoslovakia ${ }^{65}$, these Anglo-American campaigns led to the closure of the UNWCC by March 1948.

Given the UNWCC's extensive support for domestic trial processes, its focus on research and preparation rather than "in-house" trials, and the high levels of enthusiasm among many of its staff, many of its activities continued beyond its closure. Correspondence from September 1949 between former members of the Dutch National Office and J.J. Litawski, formerly a high-ranking member of the Commission and then a member of the UN's Human Rights Division, detailed dozens more Dutch UNWCC-

61 Ibid., 40.

62 Foreign Office, Winding Up of the United Nations War Crimes Commission, May 3, 1947. Part

of document held in The National Archives of the UK, Winding-up of the United Nations War Crimes Commission. Code 73 File 58, Archival Reference FO 371/66570.

63 Foreign Office, Cooperation of the UNWCC with the Human Rights Division, the United Nations, Colonel G.A. Ledingham, January 30, 1947. Part of document held in The National Archives of the UK, Winding-up of the United Nations War Crimes Commission. Code 73 File 58,

Archival Reference FO 371/66570.

64 F.F. Garner, Future of the UNWCC, January 9,1947. Part of document held in The National Archives of the UK, Winding-up of the United Nations War Crimes Commission. Code 73 File 58, Archival Reference FO 371/66570.

65 Christopher Simpson, The Splendid Blond Beast: Money, Law, and Genocide in the Twentieth Century (New York: Grove Press, 1993), 274-277. 
supported cases that were only then coming to completion ${ }^{66}$. Since these came after the UNWCC's reporting period, we cannot know how many such cases there were across the member states, but these do attest to the lingering positive impact of its early "capacity-building" measures. In addition, just before its closure, the UNWCC assembled a number of documents for the early United Nations bridging human rights and international law, including the history cited throughout this chapter, and its report on human rights and international law submitted to ECOSOC in $1948^{67}$. Thus, despite its closure, the UNWCC continued to contribute to criminal justice.

\section{The Policy Significance of the UNWCC today: Complementarity and Institutional Model}

The UNWCC, we have seen, represented a different approach to international criminal justice to the International Military Tribunals—one that is not merely of historical interest, but has potential policy relevance today. This section will discuss some of the ways this relevance might manifest, with a particular focus on the degree to which the UNWCC's example can contribute to modern discussions surrounding, proposals for, and requirements of positive complementarity. After a discussion of what positive complementarity entails, and a survey of how it has been implemented across a range of international organizations, we will consider some of the ways that a UNWCC-like approach might be able to bolster these efforts.

The UNWCC primarily played a facilitatory role in wartime and postwar international criminal justice. Rather than try to launch its own international trial structures for all cases reported into it, it instead aimed to improve the functioning of existing legal systems across Allied states, in line with Roosevelt's goal of making sure that Nazi war criminals would "stand in courts of law in the very countries which they are now oppressing and answer for their acts". It did this by pooling (largely informational and expertise-based, rather than financial) resources and best practice, coordinating trial and prisoner-handling efforts, and by providing scrutiny and review of cases, to minimize the risk of summary or unfair justice. These is-

66 Letter from Joyce Sweeney, Secretary to Dr. M.W. Mouton, to Dr. J.J. Litawski, Consultant on War Crimes Trials, United Nations Division of Human Rights, (September 2, 1949) (on file in Reel 61 of the UNWCC archive).

67 UNWCC, Information Concerning Human Rights, 1948, 125-145 and Appendix. 
sues were particularly key for the governments-in-exile, who had fled the occupation of their countries and lacked the judicial infrastructure, personnel, and large-scale information-gathering ability they would usually need to carry out even the preparatory stages of trials.

To use anachronistic modern terminology, the UNWCC's facilitatory role thus closely resembled modern-day notions of legal capacity-building and "positive complementarity". This is a concept that emerges from Article 17 of the Rome Statute of the International Criminal Court, whichamong other provisos-restricts the ICC to only investigate cases where states are "unwilling or unable genuinely to carry out the investigation or prosecution" ${ }^{68}$. Especially in the latter case, Article 17 directs the Court to consider the degree to which, "due to a total or substantial collapse or unavailability of its national judicial system, the State is unable to obtain the accused or the necessary evidence and testimony or otherwise unable to carry out its proceedings" ${ }^{69}$. While nominally an eligibility criterion (and a resource-saving device-by making the ICC into a court of last resort, it reduces the burden on it having to hear cases), this notion of complementarity has developed significantly, evolving into a "classical" (or "negative") approach and a more "positive" notion, by which the ICC (and potentially other bodies) are empowered and encouraged to combat unwillingness and inability through a variety of measures ${ }^{70}$. While the extension and desirability of this more "pro-active" approach have been questioned by some $^{71}$, a wide range of theorists have highlighted it as a desirable and effective approach for the ICC to take in promoting accountability for major crimes $^{72}$. Indeed, the notion of "positive complementarity" has been ex-

68 ICC, Rome Statute of the International Criminal Court, Article 17(1)(a).

69 Ibid., Article 17(3).

70 Carsten Stahn, "Taking Complementarity Seriously: On the sense and sensibility of 'classical', 'positive', and 'negative' complementarity," Carsten Stahn and Mohamed M. El Zeidy (eds.), The International Criminal Court and Complementarity: From Theory to Practice (Cambridge: Cambridge University Press, 2011), 260-281.

71 See, for example, Marlies Glasius, "A problem, not a solution: Complementarity in the Central African Republic and Democratic Republic of the Congo;" Paul F. Seils, Making complementarity work: Maximizing the limited role of the Prosecutor, both in Stahn and El Zeidy (eds.), The International Criminal Court.

72 Michael A. Newton, "The quest for constructive complementarity; Michael Burke-White, Reframing positive complementarity: Reflections on the first decade and insights from the US federal criminal justice system;" Christopher K. Hall," Positive complementarity in action;" Morten Bergsmo, Olympia Bekou, and Annika Jones, "Complementarity and the construction of national ability;" all in Stahn and El Zeidy (eds.), The International Criminal Court. 
tended to cover a wider spectrum of phenomena where international legal institutions provide assistance to improve the capacity of domestic ones, to shift the caseload from the international to the domestic level. The ICTY's work in case-transfer to domestic jurisdictions highlighted as a particularly successful example ${ }^{73}$, as has the prosecution-ordering and supervisory roles of the Inter-American Court ${ }^{74}$.

This is not merely a theoretical recommendation, but is widely recognized throughout a wide range of international organizations' strategies, stated goals, and action plans, both in overarching and general terms, and in the specific strategic action plans of individual bodies.

Perhaps predictably, this is clear in the ICC's own work. In its twenty years of operation, the ICC has only completed a very small number of cases, issuing 8 convictions and 2 acquittals in 6 cases; while a wide range of factors contribute to this, issues like low capacity for trials, difficulty in encouraging willingness among states to participate are key issues, leading to positive complementarity being seen as an important complement to trials of major criminals. In its three-yearly "Strategic Plans of the Office of the Prosecutor", the ICC has (in at least four reports in a row) emphasized the importance of positive complementarity and capacity building as a core component of the Office of the Prosecutor ${ }^{75}$. These stress the importance of assisting national and regional judiciaries in organizing domestic trials

73 David Tolbert and Aleksandar Kontic, "The International Criminal Tribunal for the former Yugoslavia ('ICTY') and the transfer of cases and materials to national judicial authorities: Lessons in complementarity;" Fidelma Donlon, "Positive complementarity in practice: ICTY Rule 11 bis and the use of the tribunal's evidence in the Srebrenica Trials before the Bosnian War Crimes Chamber;" both in Stahn and El Zeidy (eds.): The International Criminal Court.

74 Alexandra Huneeus, "Pushing States to Prosecute Atrocity: The Inter-American Court and Positive Complementarity," Heinz Klug (ed.), The New Legal Realism: Studying Law Globally, Volume 2 (Cambridge: Cambridge University Press, 2016), 228.

75 ICC Office of the Prosecutor, Report on Prosecutorial Strategy, (ICC, 2006), 5, https: //www.icc-cpi.int/NR/rdonlyres/D673DD8C-D427-4547-BC69-2D363E07274B/14 3708/ProsecutorialStrategy20060914_English.pdf (accessed on 9 September 2018); ICC Office of the Prosecutor, Prosecutorial Strategy, (ICC, 2010), 5, https://https:// www.icc-cpi.int/NR/rdonlyres/66A8DCDC-3650-4514-AA62-D229D1128F65/2815 06/OTPProsecutorialStrategy20092013.pdf (accessed on 9 September 2018); ICC Office of the Prosecutor, Strategic plan June 2012-2015, (ICC, 2013), 13, https://w ww.icc-cpi.int/iccdocs/otp/OTP-Strategic-Plan-2013.pdf (accessed on 9 September 2018); ICC Office of the Prosecutor, Strategic plan / 2016-2018, (ICC, 2015), 22, 44-45 https://www.icc-cpi.int/iccdocs/otp/en-otp_strategic_plan_2016-2018.pdf (accessed September 9, 2018). 
before cases reach the ICC, both as a positive goal in its own right, and as a way of making the Court's already stretched resources go further by enabling cases to be heard at domestic levels. The ICC has even mooted the possibility of "enhancing coordination of activities and developing a common understanding of how to conduct [investigations and prosecutions where perpetrators or victims have crossed state borders]" in cooperation with bodies such as Interpol, perhaps via a "common platform for improved interaction between the relevant members of the law enforcement community"76. Explained in general terms, this is closely reminiscent of UNWCC institutions such as CROWCASS, that provide worked and workable examples of what such cooperation might look like.

At the same time, this has seen limited implementation-in the most recent Strategic Plan, the ICC's Bureau of Stocktaking explicitly places the court outside the provision of "capacity building, financial support, and technical assistance", suggesting instead that this would be an activity for member states to carry out on a voluntary basis ${ }^{77}$. Even where it does endorse positive complementarity as a concept, its implementation of it is, to quote Nidal Nabil Jurdi, "patchy", "ignoring or overlooking—at best" the principle, and rushing to take on cases that could and should have been handled domestically ${ }^{78}$, a critique that has also been raised by the European Parliamentary Research Service ${ }^{79}$.

Other regional courts and institutions have also incorporated the notion of capacity building, cooperation, and coordination as key components of an effective system of domestic and international accountability for major crimes, with varying levels of success.

In its 2017-2021 Strategic Action Plan, the Inter-American System for Human Rights commits itself-under its broader Strategic Objective 4 (addressing the universalization of its implementation by links with "other international, regional, and sub-regional human rights agencies and mechan-

76 ICC, 2013, 29.

77 ICC, 2015, 22.

78 Nidal Nabil Jurdi, “The Complementarity Regime of the International Criminal Court in Practice: Is it Truly Serving the Purpose? Some Lessons from Libya," Leiden Journal of International Law 30 (2017), 219.

79 Ionel Zamfir, International Criminal Court: Achievements and challenges: 20 years after the adoption of the Rome Statute (European Parliamentary Research Service, 2018), 10, http://www.europarl.europa.eu/RegData/etudes/BRIE/2018/625127/EP RS_BRI(2018)625127_EN.pdf (accessed September 9, 2018). 
isms" ${ }^{80}$ ) to a wide range of programs aimed at sharing information and best practice (P13), coordinating criminal justice efforts (P14), and promoting technical cooperation on human rights institutions $(\mathrm{P} 11)^{81}$. Indeed, the Inter-American Court (a subsidiary of the IAS) routinely directs domestic courts to investigate and prosecute acts amounting to crimes against humanity, and issues follow-up supervision, reporting, and recommendation regimes ${ }^{82}$. While beset by problems, including low compliance and a slow progress rate leading to evidence loss and the deaths of witnesses, perpetrators, and victims to old age ${ }^{83}$, it nonetheless has a number of significant achievements. Huneeus describes how it has provided support to over fifty cases across South America, received greater buy-in from local actors than it seems likely that international intervention would have achieved, and developed a significant body of case law and practice, including a greater emphasis on truth-telling, symbolic reparations, and other forms of accountability procedures.

The European Commission also emphasizes positive complementarity as a key part of its approach to international criminal justice promotion. As part of its 2013 Staff Working Document on Advancing the Principle of Complementarity - the Toolkit for Bridging the Gap Between International \& National Justice - the Commission suggests that successful international criminal justice "must be ensured by taking measures at the national level and by enhancing international cooperation". As part of this, it provides a brief summary of some of the most effective forms of immediate and longer-term assistance for supporting countries with damaged judicial infrastructure and a desire to prosecute atrocity $\mathrm{crimes}^{84}$, as well as a range of legal and infrastructural measures, such as support for travelling courts and archival measures ${ }^{85}$. At the same time, this has seen limited practical realization; while the EU remains a significant donor to legal development, the toolkit itself has largely been realized through "operational ... internal guidelines" to its staff, and recommendations of "operational en-

80 Inter-American Commission on Human Rights, Strategic Plan 2017-2021, 2017, 48, http:/www.oas.org/en/iachr/mandate/StrategicPlan2017/docs/StrategicPlan20 17-2021.pdf (accessed September 9, 2018).

81 Inter-American Commission on Human Rights, 2017, 49.

82 Huneeus, 2016, 228.

83 Ibid., 236.

84 European Commission, Joint Staff Working Document on advancing the principle of complementarity - Toolkit for bridging the gap between international and national justice, 2013, 12, http://register.consilium.europa.eu/doc/srv?l=EN\&f=ST\%206783\%2 02013\%20INIT (accessed September 9, 2018), 12.

85 Ibid., 20-21. 
try points" for other programs, rather than concerted institutional change in its own right ${ }^{86}$.

Positive complementarity is, therefore, a significant recent development in international criminal law and its supporting institutions-building from a centralized international court system, as seen at Nuremberg, to a model where such courts are a measure of last resort, and seek to reduce demand for them by developing the capability of individual states and domestic judicial systems. At the same time, it could see deeper and more effective implementation-many of the calls for positive complementarity described above take the form of proposed models for future work, while positive complementarity efforts today are often either geographically limited (as with the IACHR), more planned than implemented (as with the EU), or patchy and poorly implemented (as with the ICC). What can the UNWCC's model contribute to improving the implementation of this principle? At the risk of elaborating additional plans and ideas to a field currently more lacking in implementation, the UNWCC's history represents a series of practical examples of positive complementarity in action that could inform and embolden current practice. We identify three areas where this could help.

\section{Technical Assistance}

One of the clearest forms of support offered by the UNWCC would be its role in providing technical assistance and coordination for the indictment, and later prosecution, of war criminals. Individual states may have been responsible for the actual prosecution of those involved in major crimes, but by providing bureaucratic, administrative, and informational support for member states, the UNWCC made this process more effective, especially in cases where jurisdictions overlapped. While modern, and currently proposed, positive complementarity regimes do respond to similar needs, the Commission's work provides a number of innovations and worked examples of such assistance that could contribute to modern practice.

One of the most basic contributions that the Commission made to wartime and postwar international criminal justice would be its administrative and centralizing role. By providing a unifying set of standards and

86 Coalition for the International Criminal Court, EU a key player in ICC system, February 3, 2015, http://www.coalitionfortheicc.org/news/20150203/eu-key-player -icc-system (accessed September 9, 2018). 
forms by which war crimes could be reported and categorized, as well as a forum in which individual states could share and disseminate best practice to other members, the UNWCC provided a basic-yet-effective system which could continue to prove relevant today.

Examining the minutes of meetings and correspondence between the Commission and its National Offices, even minor developments such as standardized reporting forms, lists and categorization of crimes, and lists of information gathered, seem to have been highly useful to the Commission's work, by ensuring a harmonized system of best practice across its member states.

Each of the Commission's over eight thousand charge files contained (at least in theory-some Offices were better at providing indictments than others) the same distinct categories of information, including a standardized scheme for identifying perpetrators, temporal and geographical data to locate crimes, specific war crimes committed, summary of the evidence in support of a given indictment, and even basic case-appraisal data such as the degree to which the accused was acting in an official capacity, the probable defense, and the completeness of the case ${ }^{87}$. By providing an easyto-use guide for member states as to the collection of data, encouraging them to standardize their reporting procedures when they strayed away from this ${ }^{88}$, and even providing extra specimen forms for member states who had run out ${ }^{89}$, the UNWCC could ensure that its members hewed to a basic standard of case/indictment completeness, encouraging fairer and more effective trials. This applied whether they were well-resourced great powers not subject to invasion (such as the United States) or governmentsin-exile reliant on embattled resistance networks smuggling information out of occupied countries under pain of death (such as France and Poland).

87 Many features of which are present in the Specimen Form drafted at the start of the UNWCC's operation in 1943. See UNWCC, Notes of Unofficial Preliminary Meeting held at 2:30pm, on the 26th October, 1943, at the Royal Courts of Justice, London; and UNWCC, Transmission of particulars of War Crimes to the Secretariat of the United Nations War Crimes Commission (December 1943).

88 See, for example, UNWCC Sub-Committee on Facts and Evidence, Note by the Secretary General on the first batch of cases transmitted by the French National Committee, February 8, 1944.

89 UNWCC, Correspondence between Belgian National Office and UNWCC Committee I, April 27, 1944. 
Figure 1. A sample Charge File, of the sort used by every member state. Subsequent pages include detailed descriptions of ghetto liquidations, lists of perpetrators from high-ranking generals to individual line soldiers, summaries of witness statements (and, in other cases, hand-drawn maps of death camps), and discussions of how complete the case was and perpetrators' likely defenses.

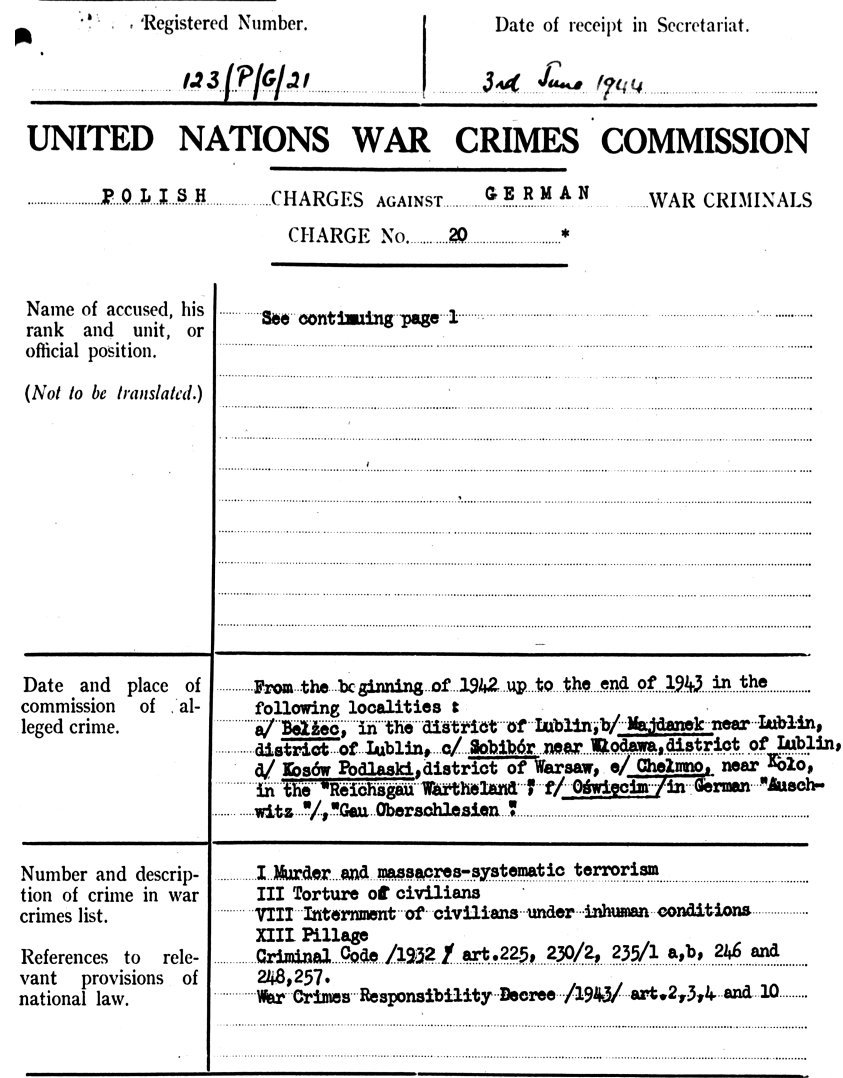

SHORT STATEMENT OF FACTS.

In connection with the liquidation of the Jewish ghettos throughout Poland during the period 1942-1943 and in order to facilitate and speed up the mass-killing of Jews several special. camps for the exter mination of Jews were established by the Germans in Foland in which more than one and a half million Polish Jews were murdered as woll as a large than one and a half million Polish Jows were murdored as well as a large 1.e. electric current and gas. 
This technical and administrative standardization was not limited to fixed reporting formulae, either. The UNWCC continued to refine its reporting procedures, organizing gatherings such as the 1945 National Offices Conference, where-towards the end of the war-the member states of the UNWCC gathered to "meet, compare notes and discuss the whole position, with the object of pooling information and improving their methods, thus inducing a feeling of solidarity and co-operation and common purpose which should be invaluable in the work which still lay ahead"90. The three-day conference included what would now be recognized as extensive "dissemination of best practice"-amidst broader discussions of how best to handle the flood of war crimes cases in liberated Europe (especially regarding the storage and handling of witness statements, and the disposition of cases where a single perpetrator had carried out crimes in multiple jurisdictions), states shared details of how they carried out their work. One report by Lt. Col. J.V. Hodgson, the American representative, provided a detailed (down to the colors of pins used to indicate different types of data source) overview of the information flow that the US Judges Advocate General and military used to gather information and notify relevant bodies about information related to war crimes, to create a system that was "flexible, capable of expansion ... enabled one to find the document required", and could operate in hostile conditions including ones without access to electricity, without specially trained operators ${ }^{91}$. While recognizing that the scale of this system made it difficult to graft it onto already existing practices elsewhere, Hodgson and the representatives of the National Offices used the Conference to work out systems of information dissemination between the various offices, SHAEF, and the Commission itself. These efforts, together with institutions such as CROWCASS, provided a centralized system of bureaucratic and technical assistance to its member states, increasing their ability to pursue war criminals, especially in large, complex cases where suspects needed to be transferred to other jurisdictions.

What use is this today? In some cases, modern information technology and bureaucratic methods reduce the need for such approaches. Centralized digital databases and widespread access to computers mean it is no longer necessary for national governments to request an international agency to print off more copies of a vital form for them, and complex filing systems like those proposed by Hodgson are similarly unnecessary-

90 United Nations War Crimes Commission, National Offices Conference, 1945, 3.

91 Ibid., 13-15. 
there is no need to have a dramatic network of pins when geotagging software exists. Nonetheless, the notion of a bureaucratically robust, centralized and standardized set of guidelines for war crimes reporting is surprisingly important (and underused) in modern international criminal law.

A UN Development Program evaluation of mobile courts in Sierra Leone, the Democratic Republic of Congo, and Somalia, found that supporting mobile courts was an effective way of promoting accountability and justice for widespread crimes such as sexual violence, with the roving and dispersed nature of circuit courts helping to further reduce the sense of justice as something only available in civic centers, but also noted significant logistical difficulties with visiting and working in remote areas ${ }^{92}$. Attention to developing a more rugged and robust system of reporting and categorizing major crimes remains a problem, therefore, even into the twenty-first century.

Similarly, in its 2009 manual of "developed practices", the ICTY noted that "the structure and wording of an indictment can be affected by the complexity of the case which can require inclusion of a large amount of information"- a failure to properly handle this could lead to "serious consequences" for the case's success. To address this, the ICTY developed a program of "organization and standardization in the form and content of indictments" 93 , which were much more capable of surviving legal challenges and led to fewer disrupted or failed trials. While, as Patrick L. Robinson, former ICTY president noted, the manual deliberately discussed "developed" rather than "best" practices-noting that "there are no grounds to claim that the practices developed by the Tribunal are better than those of any other court or legal system", and offering a "warts and all disclosure" of its approaches, this nonetheless seems to echo the successes of the UNWCC.

Finally, the notion of international institutions as sources of bureaucratic and administrative coordination for national trials is one that has found currency among international institutions in the ICC. Silvana Arbia and Giovanni Bassy - the former Registrar of the ICC, and its Special Adviser on External Relations and Cooperation respectively-outline a wide range

92 UNDP, Evaluation of UNDP's Support to Mobile Courts in Sierra Leone, the Democratic Republic of Congo, and Somalia (2014), 3-15, http://www.undp.org/content/u ndp/en/home/librarypage/crisis-prevention-and-recovery/evaluation-of-undp-s-sup port-to-mobile-courts-in-drc--sierra-leo.html (accessed September 9, 2018).

93 ICTY, ICTY Manual on Developed Practices (Turin: UNICRI, 2009), 38, http://www .icty.org/x/file/About/Reports\%20and\%20Publications/ICTY_Manual_on_Develo ped_Practices.pdf (accessed September 9, 2018). 
of ways in which the ICC's own administrative components could contribute to a system of "proactive complementarity", examining "how to coordinate [national legal and judicial systems] so that their work is coherent and effective" 94 . These include providing training and support in national information handling and court management programs ${ }^{95}$, as well as support for complex cases wherein participants in trials (in this case, witnesses rather than defendants) need to be transferred ${ }^{96}$. Arbia and Bassy note that the administrative resources of the ICC have been under-used in these cases - these are areas of potential improvement-and the UNWCC's history provides some indication of what such a system might look like.

Such technical assistance-based approaches would not merely be effective, but the UNWCC suggests they could also be cost-efficient-as Lord Wright noted, the UNWCC was the least expensive international commission known in history, a success that remains clear today. The UNWCC's annual expenditures were: 10 October 1943- 31 March 1944 (£730), 1 April 1944-31 March 1945 (£4,238), 1 April 1945-31 March 1946 (£12,462), 1 April 1946-31 March 1947 (£15,137), and 1 April 1947-31 March $1948(£ 15,388)^{97}$. Its total budget, approximately $£ 47,955$, represents approximately $£ 1.66$ million ( $\$ 2.16$ million) in today's money-a small fraction of the operating budget of major international criminal legal institutions. Stuart Ford, the former assistant prosecutor at the ECCC, estimates that UN member states had spent approximately US $\$ 6.3$ billion on the ICC, the International Criminal Tribunals for the former Yugoslavia and for Rwanda, the ECCC, and the Special Court for Sierra Leone by the end of $2015^{98}$, by contrast. It even compares favorably to many legal capacity-building projects today-the EU's recent program of financial assistance to Bosnian-Herzegovinian lawyers to assist with war crimes processing was $€ 14.86$ million ( $\$ 17.3$ million) over five years ${ }^{99}$.

94 William Burke-White, "Proactive Complementarity: The International Criminal Court and National Courts in the Rome System of Justice," Harvard Journal of International Law 49 (2008), 55.

95 Ibid., 58, 60-62.

96 Ibid., 59-60.

97 UNWCC, History, 1948, 134.

98 Stuart Ford, "How Leadership in International Criminal Law is Shifting from the United States to Europe and Asia: An Analysis of Spending on and Contributions to International Criminal Courts," Saint Louis University Law Journal 55 (2011), 956-957.

99 Delegation of the European Union to Bosnia and Herzegovina \& European Union Special Representative in Bosnia and Herzegovina, The EU releases 2.9 
In some ways, this is an unfair comparison-the UNWCC only aimed at bolstering a specific part of the legal system of the prosecuting countries in question, meaning that the majority of the costs would be borne by them rather than the international system. In addition, the UNWCC was operating under wartime, in extremis conditions that allowed it to marshal legal expertise more cheaply, and dealt with an earlier, less complex international legal landscape. Nonetheless, the fact that the UNWCC managed to operate a basic but effective centralized program of technical assistance -which, as Lord Wright noted, had its first meeting sheltering in the cellar of the Law Courts under cruise missile bombardment ${ }^{100}$ — does suggest that it is an approach worthy of some consideration. Ford notes that "it is well understood by scholars and practitioners that trials at international criminal courts are expensive, at least compared to the average domestic criminal prosecution"101_by improving the ability of domestic courts to carry out these sorts of trials, using some form of centralized technical assistance agency, justice could be arrived at more cheaply.

\section{Legitimation}

Another way that the UNWCC model could inform contemporary international legal institutions would be through encouraging a culture of legitimation, ensuring that each member states' cases were reviewed and scrutinized by a panel of leading jurists from other members.

One of the most direct ways that the UNWCC interacted with trial systems was through the work of Committee I (Facts and Evidence) in legitimating cases. As discussed above, in the interests of demonstrating that there was a prima facie case for prosecution, each case was reviewed by a panel of eminent jurists, to ensure that there was a case to be answered for. This was by no means a "rubber stamp" process-the History of the UNWCC shows that 454 cases were withdrawn by member states, adjourned, or outright dropped by the Commission. In many other cases, those named in indictments were given provisional status as "suspects", rather than "accused", indicating a lower confidence interval due to lack of evi-

million EUR for war crimes processing in Bosnia and Herzegovina, December 12, 2015, http://europa.ba/?p=39322 (accessed September 9, 2018).

100 UNWCC, Minutes of One Hundred and Thirty Fifth Meeting - M135 (March 31, 1948), 15-16.

101 Ford, "Leadership in International Criminal Law," 957. 
dence of specific suspects' wrongdoing, or a failure to properly indicate the legal basis for a charge.

This was typically used as a spur to encourage governments to improve the quality or specificity of their case files, and in many cases, this was exactly what happened. In the charge file of SS Lieutenant General Gunther Pancke, Committee gave the original dossier a "suspect" designation in October 1944, but upgraded him to a full "accused" in 1945 after Danish sources provided a selection of primary source reports identifying him for his role in mass killings, and the Commission merged its own investigation of Pancke with that of the Danish government ${ }^{102}$. In other cases, national offices provided their own revised and redrafted indictments containing more detailed material to upgrade this status-the initial Greek indictment of Major Paul Radomski, commander of the Haidari concentration camp, for example was extremely brief and provided few details, but the later follow-up-with specific details of the dates and crimes committed, as well as witness statements by specific named individuals, was merited an "accused" designation ${ }^{103}$. Without specific documentation from the Greek National Office it is difficult to say for sure, but it seems that receiving the UNWCC's imprimatur served as a spur to improve indictment reporting.

Thus, information-sharing and case-review by the Commission and its member states-spurred by Committee I's identification of areas of weakness and potential improvement in its cases-could improve the ability of states to bring effective charges in domestic settings. States did not necessarily have to participate in the Commission's processes, but the fact that they did, and, as seen in the Greek case above, put significant effort into improving their charge files, suggests that the possibility of international legitimacy from a country's peers did draw them to participate, improving the willingness of states to bring effective charges.

This sort of approach-international checking and legitimation of cases at a pre-trial stage-could be a significant boon for domestic genocide prosecutions. These have, in many cases, run into problems where there may have been a case to answer, but there was insufficient evidence to prove the charges listed, or another charge should clearly have been ap-

102 UNWCC, Danish Charges against German War Criminals (Lieutenant General Gunther Pancke), Registered No: 2868/D/G/2 / 9/Com/G/9. Case No. 2, April 11, 1946.

103 UNWCC, Greek Charges against Germn War Criminals (Major Paul Radomski), Registered No: 384/Gr/G/6, Case No. 7 / G2/G/7, November 7, 1944 / May 1, 1946. 
plied based on the evidence available to the courts. The guilty verdict in the Kravica case in Bosnia-Herzegovina, for example, was annulled leading to a retrial in 2013, due to the court erroneously using the 2003 Penal Code retroactively ${ }^{104}$, while in Kosovo, the Vukovic case was overturned and subject to retrial not only because of poor trial standards, but also because of an inadequately precise and poorly proven charge of genocide, where a charge of war crimes would have been more clearly provable ${ }^{105}$. In both cases, flaws early in the trial process led to verdicts being overturned, often in part due to extensive international pressure, leading to extensive retrials. These could have been minimized with some degree of Committee I-style "sense checking", in which states prosecuting major crimes (and, being in post-conflict situations, also likely dealing with disrupted legal infrastructure) could submit their cases to pre-trial review to ensure that there was at least a prima facie case to answer. Indeed, the ICTY seems to have over time developed a similar procedure in its own (albeit international) process, describing a similar (but informal) "peer-review" process for indictments, which "helped produce a consistent approach ... often exposed problems with an indictment [and] highlight[ed] the need for better evidence or further investigation, and produced suggestions for improvement"106. Such an approach could be broadened to internationally-supported domestic trials for major crimes, much as the UNWCC did, with similar results.

Persuading states to participate in such a process is likely to be difficult - since it would represent a ceding of judicial independence to external scrutiny, which might not approve an indictment-but by reducing the costs of retrial, formalizing a process of judicial review at an earlier stage, reducing the likelihood of politically unpopular "failed trials", and providing international approval for prima facie cases, states could be persuaded to participate in the process. In addition, such an approach might also help ease tensions surrounding extradition and transfer of defendants between countries that might otherwise be suspicious about extraditing their citizens to other states, on the grounds that they did not believe they would

104 Justice Report, Kravica - News, Analysis and Opinion: Justice Report (2013), http:// www.justice-report.com/en/cases/kravica-news-analysis-and-opinion/29/2\#o29 (accessed September 9, 2018).

105 Michael Hartmann, Re: 12-year prison sentence in Kosovo war crimes trial, University of Buffalo JUSTWATCH Listserv (2002), https://listserv.buffalo.edu/cgi-bin/w a?A2=ind $0210 \& \mathrm{~L}=$ JUSTWATCH-L\&D=0\&P=281955 (accessed September 9, 2015).

106 ICTY, 2009, 39. 
receive a fair trial. By increasing transparency surrounding the pre-trial process, and by giving states a stake in legitimation-based processes to ensure that their citizens received a fair and effective trial and were not simply facing illegitimate charges in a kangaroo court, this could improve the likelihood of trials going ahead in the first place. In the UNWCC's case, the reality fell short of the ideal, as we have seen, given the difficulty extraditing accused war criminals from US custody, but this could still prove useful, especially in post-conflict situations where former belligerent countries are wary about extraditing accused war criminals to each other. This is an issue that has been particularly noted in the former Yugoslavia, for example, with Human Rights Watch noting in 2006 that post-conflict war crimes prosecutions were severely hampered by extradition difficulties in Republika Srpska ${ }^{107}$ and Bosnia-Herzegovina ${ }^{108}$. While providing a forum in which they could review each others' cases to indicate that there was a prima facie case would not solve every problem with this-and might risk tit-for-tat disruption of trials, especially since members would not be bound together by the intense interstate bonds produced by the common experience of fighting World War Two together-such a model might reassure states and national publics about the prospect of extraditing their citizens, by allowing them oversight enough to tell that there was not simply a show trial awaiting them. This would encourage recalcitrant states to overcome domestic opposition to war crimes cases. In a similar way, this might also reduce the likelihood of international support for war crimes prosecutions from deadlocking in venues such as the UNSC, where one state or another might veto prosecutions; while the risk of bad-faith obstructions (to protect geopolitical allies) might be increased by adding more areas for disruption, it would provide states genuinely concerned that allied states were not receiving a fair trial more opportunities to ensure cases were fairly grounded without blocking the whole prosecution process.

Finally, pre-trial legitimation of indictments might help increase trial speed. Drawn-out trials of perpetrators accused of major crimes are often associated with negative results; they can often result in the deaths of elderly perpetrators while on trial (as in the cases of Slobodan Milosevic and

107 Human Rights Watch, A Chance for Justice? War Crime Prosecutions in Bosnia's Serb Republic (2006), https://www.hrw.org/reports/2006/bosnia0306/bosnia0306 web.pdf (accessed September 9, 2018), 36-37.

108 Human Rights Watch, Looking for Justice: The War Crimes Chamber in Bosnia and Herzegovina (2006), https://www.hrw.org/reports/2006/ij0206/ij0206web.pdf (accessed September 9, 2018), 20-21. 
Efrain Rios-Montt in the former Yugoslavia and Guatemala, and 43 former members of the Derg government in Ethiopia across the ten years of the trial $^{109}$ ), additional trauma for victims as they deal with drawn-out uncertain legal processes, and, as mentioned above, greater expense. These issues were recognized by the UNWCC-while, as French representative M. Gros noted, "[al]though the notion of swift justice is found in manuals of military law, "justice" is something that does not admit of qualifying adjectives"110, the organizers of the Commission widely noted that speedy trials, brought with as little delay as possible, were desirable. They would reduce the risks of vigilante violence, reduce the risk of the "escape of the guilty"111, and ensure that justice was actually done rather than dragging out over time. Many ensuing UNWCC-supported trials were perhaps too quick for modern standards of criminal justice (many lasting between four and five days; trials of major criminals such as Amon Goeth (Commandant of Plaszow Camp) and Rudolf Höss (Commandant of Auschwitz) lasting a little longer, and even more complex trials such as the Belsen Trials, lasting 54 days in court ${ }^{112}$ ), and many of these would be unacceptable for modern human rights or legal commentators-Goeth, for example, was executed eight days after he was found guilty, without appeal. Nonetheless, this does suggest that some sort of pre-trial, legitimizing body that spurred states to gather strong indictments that stood up to international scrutiny could be helpful to the prosecutions of major criminals, by enabling the swifter and more engaged process of domestic justice. Reducing the needs for trials to be "reset", and assisting preparatory work on trials, could therefore both be useful.

\section{Verification}

As mentioned above, the UNWCC's primary role was in coordinating indictments, reviewing early stage cases, and providing a centralized planning structure for the decentralized system of national offices, domestic judicial systems, and military courts that made up the wartime and postwar

109 Edward Kissi, Revolution and Genocide in Ethiopia and Cambodia (Lanham: Lexington Books, 2006), 103.

110 Dan Plesch and Shanti Sattler, "A New Paradigm of Customary International Law," Criminal Law Forum 25.1 (2013), 28-29, n39.

111 UNWCC, History, 109.

112 UNWCC, Law Reports of Trials of War Criminals: Volume I (London: His Majesty's Stationery Office, 1948), 1-21. 
criminal justice system. As well as this function-that its then-chairman, Lord Wright described as akin to a "committing magistrate"113_it also sat at the center of a large-scale system of information-gathering, in the work of its Research Office (and the briefings it provided), as well as in bodies like CROWCASS.

Many of these initiatives have been replicated or superseded by presentday initiatives. With modern international human rights bodies-such as the Office of the High Commissioner of Human Rights, and the wealth of international human rights NGOs that support their work-and digital communication, there is less need for a centralized clearinghouse of information on suspected war criminals and human rights violations. In addition, bodies such as Interpol are more active in tracking alleged perpetrators across different jurisdictions, and ensuring that perpetrators are tracked down. This is a trend that the ICC has sought to develop - the Court's LEN (Law Enforcement Network) project, for example, aims "to pool resources, share relevant information and identify areas for potential judicial cooperation" 114 , bringing together Interpol, domestic, and international legal and law enforcement officials to build cooperation to track down suspects and support apprehension and extradition.

Even so, this is an area where the UNWCC's more ambitious approach could prove valuable, at least in terms of setting a high bar. The advent of the digital age, and increased NGO activity, has not obviated the value of informational clearinghouses to centralize and collect information from varieties of sources, to support domestic trials. In a different context, resources like the UNHCR's Refworld resource to collect documentation on human rights abuses leading to refugee flight in a range of countries, for example, and is heavily used in refugee law. While Interpol and the LEN do carry out extensive work tracking those responsible for major crimes, they do not do so at the ambitious scale that Simpson noted with CROWCASS-in 2011, for example, LEN had only trained 32 officials from 14 states, over a period of "years" 115 . Even without conflicts on the scale of the Second World War, modern conflicts often result in large numbers of atrocity crimes suspects fleeing across national boundaries, meaning that the demand for a robust system of suspect tracking and information exchange remains.

113 UNWCC, National Offices Conference, 1945, 7.

114 ICC Assembly of States Parties, Report of the Court on complementarity (2011), 9, https://asp.icc-cpi.int/iccdocs/asp_docs/ASP10/ICC-ASP-10-23-ENG.pdf (accessed September 9, 2018).

115 ICC Assembly of States Parties, 2011, 9. 


\section{Conclusion}

As we have seen, major, internationalized prosecutions of "archcriminals" were not the only realization of wartime and postwar thinking on international criminal justice. Predating, running concurrently with, and continuing after the International Military Tribunals in Nuremberg and Tokyo was a system of domestic prosecution of a wide range of defendants-the United Nations War Crimes Commission. Little-known today-in part because of its politicized closure and the sealing of its archives-it coordinated and supported trials on a much grander scale than the IMT, addressing a wide range of crimes and developing legal thinking considerably. As such, by studying the UNWCC's activities, and understanding postwar war crimes trials in light of the processes it set in motion, we can gather a more complete and nuanced understanding of the legacy of Nuremberg as simply one part of a broader program of accountability for atrocity crimes.

This account is not just of historical interest, however, but is relevant to scholars and practitioners of international criminal law today. The UNWCC provides an innovative approach to the implementation of positive complementarity, increasing the capability (and in some cases, willingness) of states to justly prosecute major crimes in domestic settings; by studying it, contemporary observers can draw upon "worked examples" of such measures in practice. While international criminal law patterned after the International Military Tribunals at Nuremberg and Tokyo remains a key part of international criminal justice, the UNWCC's history shows how international courts focusing on top-level perpetrators and operating at significant expense do not have to be the be-all and end-all of international criminal justice; indeed, while the Nuremberg trials were running, domestic courts drawing on international legitimation, technical/administrative assistance, and information were prosecuting a wide range of accused war criminals. Could these form models for organizations today?

We should be cautious, but optimistic, about the potential of the UNWCC as a model for international criminal justice, and a complement to a Nuremberg-inspired model. As we have noted elsewhere, many of the conditions that made it particularly effective do not pertain today ${ }^{116}$; the intense camaraderie of the Allies in the Second World War (patchy as it may

116 Dan Plesch, Thomas Weiss, and Leah Owen, "UN War Crimes Commission and International Law: Revisiting World War II Precedents and Practice," Giuliana Ziccardi Capaldo (ed.), The Global Community Yearbook of International Law and Jurisprudence (2015), 95. 
have been), confluence of legal and human rights expertise, and the unconditional surrender of the Axis states are a fairly unique historical moment. In addition, as noted in the second section of this chapter, the idea of international assistance and coordination for domestic trials is one that has already been realized, to varying extents, by different states; it is important to avoid "institutional bloat" and redundant efforts to realize positive complementarity. Nonetheless, there are four ways in which the UNWCC's legacy could be particularly relevant to contemporary practice:

Firstly, by drawing together a wide range of states, under inauspicious circumstances, to organize a pioneering program of complementary justice responsible for organizing more trials than all other international tribunals since, the UNWCC's work can serve as an inspiration for future efforts. In its pioneering legal thinking on prosecution of sexual violence, joint criminal enterprise and command responsibility, and crimes against humanity, it could help the work of modern tribunals. UNWCC thinking and policies have already been used in an Amicus brief in the prosecution of Hissène Habre, and the ECCC in Cambodia, but greater mainstreaming of its archival record could assist a wide range of prosecutions today, especially ones for crimes predating the ICTR and ICTY.

Secondly, the UNWCC offers an example of cheap, effective technical assistance, focusing on administrative support. While technical support today often takes the form of advice on questions of law, and personnel, the UNWCC's impact in fields as prosaic as standardized reporting forms and the sharing of best practice around pins in maps should not go understated.

Thirdly, the UNWCC provided a rigorous system of legitimation and "peer review" of indictments. Today, such a program could increase transparency, avert problems of legal basis that might endanger trial outcomes or fairness, and even encourage trust in fraught post-conflict regions.

Fourthly, the UNWCC demonstrated the value of centralized information pooling and coordination, especially for tracking suspects, witnesses, and evidence between different jurisdictions.

Exactly what an organization building upon these principles would look like is difficult to say, and requires investigation beyond what is outlined here. Nonetheless, these represent often-overlooked avenues of potential development in modern-day international criminal law, and are a reminder of the potential benefits of positive complementarity. By the end 
of their lifespans, both the ICTY117 and ICTR ${ }^{118}$ began to approach several similar conclusions about the benefits of complementarity, and recorded them in their best/developed practice documents-but the UNWCC represents an organization built on such principles, and is thus an important source for future development in this field that should not remain forgotten.

During the Second World War-at a time when Allied victory was still very much in doubt-countries from China to Norway, and Yugoslavia to the United States condemned Axis atrocities, and committed themselves to seeking justice and accountability for them-to "the uttermost ends of the earth", if necessary. They did not only seek to do so, however, in a centralized, international court that only prosecuted countries or heads of state, but also called perpetrators of every stripe to answer for their acts in domestic courts, closer to the crimes they were accused of committing. In this way, they prefigured modern notions of positive complementarity, blending international support and domestic trial structures to great effect. By learning from this, and implementing it in contemporary thinking and practice on international criminal justice, we can ensure that the legacy of wartime criminal justice-not just of Nuremberg—can be properly realized today.

117 ICTY, 2009.

118 International Criminal Tribunal for Rwanda Office of the Prosecuto, Complementarity in Action: Lessons learned from the ICTR Prosecutor's referral of International Criminal Cases to national jurisdictions for Trial (2015), 24-25, https://reliefweb.int/sites/reliefweb.int/files/resources/150210_complementarity_ in_action.pdf (accessed September 9, 2018). 


\title{
In Search of Imperfect Justice: \\ Genocidal Rape and the Legacy of Nuremberg and Tokyo
}

\author{
Tazreena Sajjad
}

\section{Introduction}

While sexual violence against girls and women have always been perpetrated in both times of peace and war, they have historically garnered little attention or condemnation. Patriarchal norms in most societies have meant such crimes have not been viewed as violations against women and girls per se but as private acts against a man's property, ${ }^{1}$ and therefore not subject to legislation. In the context of armed conflict, military occupation, mass violence, resistance and post-conflict transitions, women and girls have historically been subjected to rape, sexual enslavement, forcible impregnation, sexual mutilation, and/or other forms of sexual violence to inspire fear and panic, displace populations from coveted territory and send a message to the male enemy combatants about their inability to protect their 'women's honor' and by extension their community and nation in the face of an aggressive invasion. ${ }^{2}$ Such crimes have been tolerated by many military commanders, who believed that 'rape after a battle was a well-deserved reward, a chance to release tensions and relax, ${ }^{3}$ and a byproduct of war, rather than a strategy of warfare itself.

While non-sex based crimes are committed against women in the context of war, there is now overwhelming evidence that suggests that the targeting of women and girls for humiliation and death frequently have a

1 Alexandra Wald, "What's Rightfully Ours: Toward A Property Theory of Rape," Columbia Journal of Law and Social Problems 30 (1996-1997), 459-502.

2 See, for instance, Theodor Meron, Henry's Wars and Shakespeare's Law: Perspectives on the Law of War in the Later Middle Ages (New York, NY: Oxford University Press, 1993); Susan Brownmiller, Against Our Will: Men, Women and Rape (New York, NY: Ballantine Publishing Group, 1975); Peter Karsten, Law, Soldiers and Combat (Westport, Connecticut: Greenwood Press, 1978).

3 Kelly D. Askin, "Prosecuting Wartime Rape and Other Gender-Related Crimes Under International Law: Extraordinary Advances, Enduring Obstacles," Berkeley Journal of International Law 21.2 (2003), 296. 
gendered and reproductive component. ${ }^{4}$ This is certainly true in cases of genocide where the specific objective is to destroy, in whole or in part, a national, ethnical, racial or religious group. ${ }^{5}$ However, because the drafting of the rules of war have historically been done by men and premised upon false notions of 'gender-neutrality,' sex-based crimes, including those instrumentalized as a strategy of genocide, have been largely inappropriately portrayed, minimally incorporated or even rendered invisible. In addition, existing international humanitarian law (IHL) has historically not only focused on men but privileged the recognition of the non-sex based harm inflicted upon men. ${ }^{6}$ Correspondingly, the pervasiveness of such crimes have deprived innumerable women and girls of the ability to exercise their 1) civil and political rights; 2) economic, social and cultural rights; and 3) third generation rights such as the right to peace and development. ${ }^{7}$ Furthermore, given the constructed associations of women and girls with 'purity,' 'belonging,' and as 'carriers' and 'reproducers' of cultural and biological identities, rape and sexual violence, whether organized or random, orchestrated or opportunistic, in genocidal campaigns or not, result in irreparable damage to their immediate families, local communities and societies as a whole.

There is a long history of philosophical reflections on, and an effort to prohibit the use of rape and sexual violence in the context of armed conflict. However, these developments in treaties, customary practices and later in IHL, which governs jus in bello ${ }^{8}$ have progressed painstakingly at a 'snail's pace.' In fact, even the ground-breaking Nuremberg and Tokyo trials following the end of WWII, to try individuals for violations of the laws

4 Kelly D. Askin, "Comfort Women - Shifting Shame and Stigma From Victims To Victimizers," International Criminal Law Review 1.1 (2001), 5-32.

5 For a detailed definition of genocide see Convention on the Prevention and Punishment of the Crime of Genocide, adopted by The General Assembly of The United Nations on December 9, 1948, https://Treaties.Un.Org/Doc/Publication/Unts/Volume \%2078/Volume-78-I-1021-English.Pdf (accessed April 10, 2018).

6 Hilary Charlesworth, Christine Chinkin and Shelley Wright, "Feminist Approaches To International Law," American Journal of International Law 85.4 (1991), 613645.

7 Patricia Viseur Sellers, "The Prosecution of Sexual Violence In Conflict: The Importance Of Human Rights As Means of Interpretation," OHCHR, 2008, http://W ww.Ohchr.Org/Documents/Issues/Women/WRGS/Paper_Prosecution_Of_Sexual_ Violence.Pdf (accessed April 10, 2018).

8 There is a distinction in International Law between Jus Ad Bellum, the lawful right to declare hostilities, and Jus In Bello, the rules, regulations and laws for armed forces and non-state actors during an international or internal armed conflict.

9 Askin, "Prosecuting Wartime Rape." 
and customs of war and establish individual criminal culpability for war crimes, crimes against humanity and crimes of peace, largely neglected the issue of rape and sexual violence perpetrated on the civilian population, despite significant evidence of such crimes having been committed in Europe and in the Asia-Pacific. Nevertheless, their limited recognition in Nuremberg and Tokyo laid the critical groundwork for unprecedented developments in IHL and later in international criminal law (ICL) in the decades that followed.

This chapter examines the foundations of the legal and political philosophy surrounding the criminalization of wartime rape and sexual violence with a special focus on their instrumentalization during a genocidal campaign within a discussion of the legacy of Nuremberg and Tokyo. In outlining how the first two international tribunals recognized the reality of such crimes, even though both were extremely limited in adjudicating specific cases of violations, it focuses on how they helped created the legal foundation for the ad hoc tribunals of the 1990s - the International Criminal Tribunal for Former Yugoslavia (ICTY) and the International Criminal Tribunal for Rwanda (ICTR) both of which successfully prosecuted various forms of rape and sexual violence as instruments of war crimes, crimes against humanity, torture, persecution, enslavement, and, in a few cases, as instruments of genocide. In tracing their ongoing legacy in developing contemporary legal norms around rape and sexual violence, however, it finds that prosecution of genocidal rape in particular continues to be largely invisible despite the notable gains made and the 2001 establishment of the International Criminal Court (ICC). This ongoing invisibility echo the remnants of a long history in international legal jurisprudence certainly evident in Nuremberg and Tokyo, of a lack of gender consciousness that prevented the investigation and prosecution of gender-based sex crimes committed during WW II. While both tribunals ushered in a new world of individual criminal culpability and broke new grounds in international legal jurisprudence, this research finds that this ongoing absence of gender consciousness continues to shape the ongoing reluctance in the international criminal sphere and prevent potential cases of rape and sexual violence from being investigated and prosecuted as acts of genocide.

\section{Laying the Foundation: Early Developments in Criminalizing War-time Rape and Sexual Violence}

In the context of armed conflict, there are several bodies of law that address sex-based crimes, and there are substantial areas of overlap and differ- 
ences between them, as each provide specific protections. First, IHL is evoked only when an active conflict emerges. Crimes against humanity and genocide however do not need a connection to war in order to be prosecuted (unless the enabling legislation imposes the connection as a jurisdictional requirement). ${ }^{10}$ While IHL and international human rights law (IHRL) both forbid slavery and torture, the remedy question depends completely on which body of law is being applied. ${ }^{11}$ Like IHL and IHRL, ICL also prohibits the use of torture and slavery. Treaties such as the Genocide Convention explicitly impose criminal sanctions for its violation. ${ }^{12}$

A historical process-tracing of IHL is crucial for understanding how legal jurisprudence of wartime sexual violence has evolved in the international system. The earliest recognition of wartime sexual violence appears in the warrior codes in the first century, which focused on a surprisingly large spectrum of those presumed innocent-children, women, farmers, priests, merchants and scholars. ${ }^{13}$ The rationale for sparing them from the violence of warfare was not however based on contemporary understandings of human rights protection, but rather for the strategic purposes of ensuring that civilian activities such as economic production remained uninterrupted and that society largely remained functional as a cohesive political unit. ${ }^{14}$ However political exigencies determined necessary for a decisive military victory meant that sovereign rulers could exploit the exemption loophole prohibiting the use of sexual violence against civilians granted to sovereign leaders. This was demonstrated multiple times during periods of warfare when lootings, killings, pillaging and rape were sanctioned in the event the enemy did not surrender to invading forces. ${ }^{15}$

10 Ibid.

11 Ibid.

12 See Convention on the Prevention and Punishment of the Crime of Genocide, adopted on December 9, 1948, https://Treaties.Un.Org/Doc/Publication/Unts/Volume\%20 78/Volume-78-I-1021-English.Pdf (accessed April 10, 2018). However, despite a legal obligation to act in the face of genocide, it has been ignored in a variety of cases such as Cambodia and Bangladesh, which in recent years established a hybrid and a local court respectively to try individuals of war crimes, crimes against humanity and genocide, and in the case of the Rohingyas, to mention a few.

13 Sellers, "The Prosecution of Sexual Violence in Conflict."

14 Brownmiller, Against Our Will; Theodor Meron, "Shakespeare's Henry the Fifth and the Law of War," The American Journal of International Law 86.1 (1992), 1-45.

15 For instance, the 12th century Arab historian, Ibn Al-Athir recounts that the sacking of Constantinople under Greek rule in 1204, was among the most destructive acts of the Middle Ages. The Franks rampaged the city, looted and destroyed art, defiled Orthodox churches, killed clergy, and raped Greek nuns cloistered in 
In 1385, Richard II of England proclaimed several Articles of War in which he decreed, 'that none be so hardy as to ... force any woman, upon pain of being hanged. ${ }^{16}$ Additionally in the 1300s, Italian lawyer Lucas de Penna argued that wartime rape should be punished as severely as peacetime rape $;{ }^{17}$ in 1474 , Sir Peter Hagenbach was tried and sentenced to death by an international military court for war crimes, including rape, committed by his troops. ${ }^{18}$ In the 1500 s, jurist Alberico Gentili argued that the use of rape during wartime was unlawful even if there were female combatants. ${ }^{19}$ In The Law of War and Peace, $17^{\text {th }}$ century jurist Hugo Grotius argued that rape in warfare is impermissible because it breaks down the distinction between man and animals, and 'Christians' and 'barbarians,' ultimately challenging the maintenance of a social order. ${ }^{20}$ Each of these examples illustrate that long before IHL was codified, the use of rape during wartime was prohibited by existing customary international law, ${ }^{21}$ i.e. law that is legally binding irrespective of whether states are parties to the document of the time..$^{22}$ Despite such scholarly writings, violations of de jure legal proscription of the use of various forms of sexual violence were common given societal understandings of women as legitimate spoils of war along with livestock and chattel, and consequently often used as inducements to wage war with the goal of being able to have unrestricted sexual access to those who were vanquished. ${ }^{23}$ This was certainly true during the Middle Ages and the Crusades, and was just as prominent during the period of western exploration and colonization, when conquest and pillage of

monasteries. Amin Maalof, Les Croisades Vues Par Les Arabes (Paris, France: j’ai Lu, 1983).

16 Brownmiller, Against Our Will.

17 Richard Shelly Hartigan, The Forgotten Victim: A History of the Civilian (Chicago, Illinois: Precedent Publishing, 1982).

18 William Parks, "Command Responsibility for War Crimes," Military Law Review 62 (1973), https://www.Loc.Gov/Rr/Frd/Military_Law/Military_Law_Review/PdfFiles/27508F 1.Pdf (accessed April 11, 2018); Meron, "Shakespeare's Henry the Fifth And The Law of War."

19 Alberico Gentili, De Jure Belli Libri Tres (Oxford: Clarendon Press, 1933), 258-259.

20 Hugo Grotius, On the Law of War and Peace, ed. Stephen C. Neff (Cambridge: Cambridge University Press, 2012).

21 This discussion does not consider other legal traditions, particularly those considered non-western, where the use of rape and sexual violence in war is also forbidden.

22 Customary International Law is derived from state practice based on opinion juris (a sense of legal obligation).

23 Askin, "Prosecuting Wartime Rape." 
indigenous territories were seen to be justifiable measures to spread Christian values and promote racial superiority amongst 'primitive' nations.

It was not until the late 1800 s that specific prohibitions against wartime rape and sexual violence became codified to become the modern iteration of the framework of IHL. A notable number of documents are important in this development. First, the Lieber Code signed by President Lincoln on April 24, 1863 following the Civil War (also known as Instructions for the Government of Armies of the United States in the Field, General Order No. 100, or Lieber Instructions) aimed at codifying customary international law, deemed certain behavior as being acts of 'wanton and unnecessary violence,' and therefore prohibited their commission at all ranks in the Union Army. Specifically, Article 37 which governs the administration of occupied territory, stated that 'the United States acknowledge and protect, in hostile countries occupied by them, religion and morality; strictly private property; the persons of the inhabitants, especially those of women [emphasis added by author]; and the sacredness of domestic relations. ${ }^{24}$ Article 44 of the Lieber Code prohibited the use of 'all rape'25 in the context of warfare. ${ }^{26}$ Moreover, the Code's Article 47 states: 'Crimes punishable by all penal codes, such as arson, murder ... and rape, if committed ... are not only punishable as at home, but in all cases in which death is not inflicted, the severer punishment shall be preferred. ${ }^{27}$ Article I of the Annex to the II Hague Convention of July 1899 has only one single reference that vaguely and indirectly prohibits sexual violence as a violation of family honor, when stating that belligerents need to 'conduct their operations in accordance with the laws and customs of war; ${ }^{28}$ as does Article 46 of the IV

24 Article 37, General Orders No. 100: The Lieber Code, Instructions for the Government of Armies of the United States in the Field, April 24, 1863, http://Avalon. Law.Yale.Edu/19th_Century/Lieber.Asp\#Sec2 (accessed April 12, 2018).

25 Article 44 of the Lieber Code states: "All wanton violence committed against persons in the invaded country, all destruction of property not commanded by the authorized officer, all robbery, all pillage or sacking, even after taking a place by main force, all rape, wounding, maiming, or killing of such inhabitants, are prohibited under the penalty of death, or such other severe punishment as may seem adequate for the gravity of the offense. A soldier, officer or private, in the act of committing such violence, and disobeying a superior ordering him to abstain from it, may be lawfully killed on the spot by such superior." Supra note 24 .

26 Article 44, ibid.

27 Article 47, ibid.

28 Article 1, Annex to the Convention Regulations Respecting the Laws and Customs of War on Land, Section I On Belligerents, Chapter I: The Qualifications of Belligerents, http://Avalon.Law.Yale.Edu/20th_Century/Hague04.Asp\#Art1 (accessed April 12, 2018). 
Hague Convention of 1907 (the foundation of which was laid by the Lieber Code); ${ }^{29}$ this mention, sub silencio, has been interpreted to mean the prohibition of the commission of all war crimes, including rape. ${ }^{30}$

Although the original Geneva Conventions were in force during World War I, they did not extend protection to civilians. However, as mentioned above, Article 46 in the Regulations to the IV Hague Convention of 1907 has relevance to rape during wartime in terms of its prohibition. While no war crimes tribunal was established when WWI ended, the major Allied powers established the 1919 War Crimes Commission to investigate crimes and make recommendations about the appropriate level of punishment for accused Axis war criminals. What emerged was a report created by the War Crimes Commission, which listed 32 non-exhaustive violations of the laws and customs of war that had been committed by the Axis powers. ${ }^{31}$ In it, two of the enumerated offenses that were deemed as punishable offenses were 'rape' and the 'abduction of girls and women for the purpose of forced prostitution. ${ }^{32}$ In addition, while rape and sexual violence is not clearly stated in the 1929 Geneva Convention that was drafted in the decade following World War I, its Article 3 stated that 'prisoners of war are entitled in all circumstances to respect for their persons and their honor. Women shall be treated with all the regard due to their sex ...'33 While these developments were important milestones, invocations of honor with regard to sexual violence indicate that there was systemic implicit and explicit paternalism underlying the need to protect women from such

29 Article 46, Annex to the Convention: Regulations Respecting the Laws and Customs of War on Land - Section III: Military Authority Over the Territory of the Hostile State - Regulations, Convention (IV) Respecting the Laws and Customs of War on Land and Its Annex: Regulations Concerning the Laws and Customs of War on Land. The Hague, October 18, 1907, https://Ihl-Databases.Icrc.Org/Applic /Ihl/Ihl.Nsf/Article.Xsp?Action=Opendocument\&Documentid=E719FBF0283E98 E3C12563CD005168BD (accessed April 12, 2018).

30 Sellers, "The Prosecution of Sexual Violence In Conflict."

31 Askin, "Prosecuting Wartime Rape."

32 Law reports of trials of war criminals, vol. xiii, United Nations War Crimes Commission Office, 1949, https:/www.Loc.Gov/Rr/Frd/Military_Law/Pdf/Law-Report s_Vol-13.Pdf (accessed April 12, 2018).

33 Article 3, Part I Convention Relative to the Treatment of Prisoners of War. Geneva, July 27, 1929, International Committee of the Red Cross, https://Ihl-Databases .Icrc.Org/Applic/Ihl/Ihl.Nsf/Article.Xsp?Action=Opendocument\&Documentid=1 3B15ED405C8DE78C12563 (accessed April 12, 2018). 
crimes, ${ }^{34}$ and the long-standing assumption that women were ultimately the property of men. ${ }^{35}$ Till today, although rape is prohibited under international law, since it is not specifically designated as an international crime, it has to be subsumed within an established international crime such as genocide, crimes against humanity, or war crimes, in order to be prosecuted in an international criminal tribunal. ${ }^{36}$

\section{The Nuremberg and Tokyo Trials: Rape and Sexual Violence as Violations of IHL}

\section{The Nuremberg Trial}

World War II resulted in unprecedented destruction, where countless women, men and children were tortured, starved, forced into slave labor and murdered. Both across Europe and the Asia-Pacific, women and girls were also specifically targeted for sexual slavery, rape and other forms of sexual violence. The end of WWII was the first time there was an effort to acknowledge and respond to the various violations of IHL that existed at the time, resulting in the drafting of the London Charter (Nuremberg Charter) and the Tokyo Charter. The first was instrumental in the establishment for the rules and procedures governing the International Military Tribunal (IMT) with the mandate to try prominent individuals of the Nazi party (the Nuremberg Trials) while the Tokyo document laid the foundations for the creation of the International Military Tribunal for the Far East (IMTFE), i.e. the Tokyo Trials or the Tokyo War Crimes Tribunal. Both summarily laid out jurisdiction over war crimes (condemned in The Hague Conventions of 1899 and 1907), namely the violations of the laws and customs of war, crimes against humanity, and crimes against peace. However, the focus of both trials was the prosecution of those who

34 'The Protection of 'Family Honour And Rights' is a euphemism of the time [of The Hague Convention] that encompasses a prohibition of rape and sexual assault, and this provision is mandatory." M. Cherif Bassiouni, Crimes Against $\mathrm{Hu}$ manity (Cambridge, NY: Cambridge University Press, 2011), 428. Kelly D. Askin also notes that the rape of Belgian women by German soldiers during the WWI was referred to as "outrages upon the honor of women." Askin, "Prosecuting Wartime Rape,” 300.

35 Jane Dowdeswell, Women on Rape (New York, NY: Harper Collins, 1986).

36 Daniela De Vito, Rape, Torture and Genocide: Some Theoretical Implications (Hauppauge, N.Y.: Nova Science Publishers, 2011). 
launched an aggressive war, and the issue of rape and sexual violence was largely marginalized. ${ }^{37}$ For instance, while Nuremberg tried 22 Nazi war criminals, the Charter itself did not explicitly mention any form of sexual violence despite extensive verified reports of such violations having taken place during the period of war and occupation. ${ }^{38}$ The Nuremberg trial records however did contain extensive evidence of sexual violence, and one could argue sex-related crimes were included as evidence of the atrocities prosecuted. ${ }^{39}$ Two specific developments are relevant here. First, Nuremberg implicitly recognized sexual violence as torture:

Many women and girls in their teens were separated from the rest of the internees ... and locked in separate cells, where the unfortunate creatures were subjected to particularly outrageous forms of torture. They were raped, their breasts cut off ... ${ }^{40}$

$[\mathrm{W}]$ omen were subjected to the same treatment as men. To the physical pain, the sadism of the torturers added the moral anguish, especially mortifying for a wo- man or a young girl, of being stripped nude by her torturers. Pregnancy did not save them from lashes. When brutality brought about a miscarriage, they were left without any care, exposed to all the hazards and complications of these criminal abortions. ${ }^{41}$

Second, the Nuremberg Charter's Article 6(c) provided a clear definition of crimes against humanity, which is today credited for laying down the critical foundation for the laws that now prohibit rape and sexual vio-

37 Askin, "Prosecuting Wartime Rape."

38 For arguments on the grounds available for trying gender-based sex crimes if the political will was available, see Kelly D. Askin, War Crimes Against Women: Prosecution in International War Crimes Tribunals (Leiden, Netherlands: Martinus Nijhoff Publishers, 1997), 129-163. Robertson argues that a significant reason why the allies refused to indict Nazi war criminals for sexual violence was because their troops themselves committed systematic rape and tolerated such crimes particularly during the Russian military advance on Germany. Geoffrey Robertson, Crimes Against Humanity: The Struggle for Global Justice (New York, NY: The New Press, 1999).

39 Trial of the major war criminals before the International Military Tribunal [hereinafter IMT docs], Nov. 14, 1945 to Oct. 1, 1946, vol. 2, transcript at 139; vol. 6, transcript at 211-214, 404-407; vol. 7, transcript at 449-467; vol. 10, transcript at 381.

40 For some examples of documentation of sexual violence by the Tribunal, see e.g. vol. 2, transcript at 139; vol. 6, transcript at 211-214, 404-407; vol. 7, transcript at 449-467; vol. 10, transcript at 381, IMT docs.

41 Ibid. Also see vol. 7, transcript at 494, IMT docs. 
lence. ${ }^{42}$ In particular, Control Council Law No. 10, which was adopted by the occupying powers in Germany and served as the basis for later prosecutions of German military and civilian personnel at Nuremberg and elsewhere, is worth noting given it was the first time rape was listed as a crime against humanity. According to Niarchos, this law established three critical principles: '(1) rape on a wide scale could be prosecuted as a war crime; (2) crimes of sexual violence committed during peacetime could constitute crimes against humanity; and (3) responsibility for such crimes could not be limited to military personnel and ... liability could attach to persons occupying other key positions. ${ }^{43}$ Despite this, Askin notes, there was no mention of either 'rape' or 'women' in Nuremberg's 42-volume set of transcripts or in its 732-page index. ${ }^{44}$ Nevertheless in the trials of Nazi collaborators such as medical professionals who conducted medical experiments on human beings, and concentration camp guards under whose authority grave crimes were committed, the use of reproductive crimes, castration, forced sterilization and forced abortions were mentioned. ${ }^{45}$

The Nuremberg trials were monumental in terms of their contribution to how wartime rape and sexual violence, in particular, and violations of IHL in general, are understood today. First, Nuremberg established the fact that 'it is not essential that a crime be specifically defined and charged in accordance with a particular ordinance, statute, or treaty if it is made a crime by international convention, recognized customs and usages of war, or the general principles of criminal justice common to civilized nations generally. ${ }^{36}$ Second, they resulted in the establishment of the 1950

42 Article 6 (C) Nuremberg Trial Proceedings, vol. 1, Charter of the International Military Tribunal, http://Avalon.Law.Yale.Edu/Imt/Imtconst.Asp\#Art6 (accessed April 12, 2018).

43 Catherine N. Niarchos, "Women, War and Rape: Challenges Facing the International Tribunal for the Former Yugoslavia," Human Rights Quarterly 17.4 (1995), 140.

44 Askin, "Prosecuting Wartime Rape."

45 See, for instance, U.S. V. Karl Brandt, Et Al: The Doctors' Trial (On Forced Sterilization), NMT Case I, http://Nuremberg.Law.Harvard.Edu/Nmt_1_Intro (accessed April 12, 2018); U.S. V Pobl Et Al: The Indictment (on sterilization and castration), http://Avalon.Law.Yale.Edu/Imt/Indict4.Asp (accessed April 12, 2018) U.S. V Greifelt et. al, Case No. 8, International Military Tribunal (IMT), https://www.Leg al-Tools.Org/Doc/75ac90/Pdf/(accessed April 12, 2018).

46 U.S. V List Et Al, Opinion and Judgement of Military Tribunal V, the Trials of War Criminals Before the International Military Tribunal, Nuremberg, November 14, 1945-October 1, 1946, 1239 (Commonly Known as the Hostage Case), http://www.Worldcourts.Com/Imt/Eng/Decisions/1948.02.19_United_States_V_L ist1.Pdf (accessed April 12, 2018). 
Nuremberg Principles issued by the UN International Law Commission (ILC), which in turn laid the foundations for developments in ICL. ${ }^{47}$ Today, there is broad consensus that serious violations of the Geneva Conventions, its grave breaches, Common Article 3, and torture, inhuman or cruel treatment including rape can carry criminal liability and be punished as crimes of war. Third, it was in an international instrument in the Nuremberg Charter which first used the term 'crimes against humanity'48 to prosecute Nazi leaders for the gross atrocities committed against certain members of the civilian population, including German citizens during WWII. In short, Nuremberg established the concept of 'crimes against humanity,' which has brought war crimes under a different light in international law, and under the scope of human rights. However, the concept of genocide had not been developed and operationalized during the time of the Nuremberg trial, and consequently, rape and sexual violence as a specific strategy to destroy a racial, ethnic, national or religious group was not recognized.

47 Principles of International Law Recognized in the Charter of the Nuremberg Tribunal and in the Judgment of the Tribunal with Commentaries, ('Nuremberg Principles'), International Law Commission, 1950, vol. ii, http://Legal.Un.Org/Ilc/ Texts/Instruments/English/Commentaries/7_1_1950.Pdf (accessed April 12, 2018).

48 The IMT, IMTFE, CCL10, ICTY, ICTR, And ICC Statutes Or Charters have defined the scope of the crime differently. However, in essence, a crime against humanity consists of an inhumane act (typically a series of inhumane acts such as murder, rape, and torture) committed as part of a widespread or systematic attack that is directed against a civilian population. It can consist of crimes committed by a state against its own citizens and often has a discriminatory purpose. In practice, persecution and extermination appear to be the most common manifestations of crimes against humanity, and this coupling often results in genocide charges as well. See, for instance, Leila Sadat, The International Criminal Court and the Transformation of International Law: Justice for the New Millennium (Leiden, The Netherlands: Martius Nijhoff Publishers, 2002); Theodor Meron, "Rape As A Crime Under International Humanitarian Law," The American Journal of International Law 87.3 (1993), 424-428; Kelly D. Askin, War Crimes Against Women: Prosecution in International War Crimes Tribunals (Leiden, The Netherlands: Martius Nijhoff Publishers, 1997), 344-348. 
The International Military Tribunal for the Far East (IMTFE) or the Tokyo Trials

While the contributions of Nuremberg with regard to recognizing rape and sexual violence as war crimes and crimes against humanity are critical, it is important to recognize the legacy of the IMTFE, which was created through a special proclamation by General Douglas MacArthur to try leaders of the Empire of Japan for joint conspiracy to wage war, commission of crimes against humanity, and failure to prevent atrocities at the command level. Like the Nuremberg Charter, its platform did not enumerate rape or sexual violence as specific crimes committed against a civilian population. ${ }^{49}$ In fact, as Askin observes, rape was only included under the subheading 'atrocities' in the five supplementary indexes to the 22-volume set documenting the Tokyo Trial, ${ }^{50}$ representing a very minute portion of the number of times rape and sexual violence were included in the IMTFE transcripts. ${ }^{51}$ However, 'rape' and the 'abduction of girls and women for the purpose of enforced prostitution' appeared high on the list alongside other egregious war crimes. ${ }^{52}$ Unfortunately, at the IMTFE, no enforced prostitution was recorded and no rape victims were called to testify. ${ }^{53}$ The Tokyo Indictment did however characterize the rape of civilian women and medical personnel as 'inhumane treatment,' 'mistreatment,' 'ill-treatment' and a 'failure to respect family honor and rights,' and prosecuted these crimes under the 'Conventional War Crimes' provision in the Char-

49 Charter of the International Tribunal for the Far East, January 19, 1946, Http://w ww.Un.Org/En/Genocideprevention/Documents/Atrocity-Crimes/Doc.3_1946\%2 0Tokyo\%20Charter.Pdf (accessed April 12, 2018).

50 Askin, "Prosecuting Wartime Rape."

51 For some examples of documentation of sexual violence by the IMTFE see, vol. 2 , transcript at 2568-2573, 2584, 2593-2595, 3904-3944, 4463-4479, 4496-4498, 4501-4536, 4544, 4559, 4572-4573, 4594, 4602, 4615, 4638, 4642, 4647; vol. 6, transcript at 12521-12548, 12995, 13117, 13189, 13641-13642, 13652; transcripts of the proceedings and documents of the IMTFE Judgement https://Www.Legal-T ools.Org/En/Browse/Ltfolder/0_29706/ (accessed April 12, 2018).

52 Yves Sandoz, "The History of the Grave Breaches Regime," Journal of International Criminal Justice 7.4 (2009), 667-668.

53 Ustinia Dolgopol, "Knowledge and Responsibility: The Ongoing Consequences of Failing to Give Sufficient Attention to the Crimes against the Comfort Women in the Tokyo Trial," Beyond Victor's Justice? The Tokyo War Crimes Trial Revisited,' ed. Yuki Tanaka, Tim Mccor-Mack and Gerry Simpson (Leiden, The Netherlands: Brill Publishers, 2011), 248-255. 
ter. ${ }^{54}$ Correspondingly charges were brought against defendants for war crimes committed during the Nanjing invasion under the 1907 Hague Convention IV and 1929 Geneva Convention, when horrific atrocities were perpetrated against women and girls during the six-week invasion of the city. ${ }^{55}$ In total, the Tokyo Trials charged 28 Axis personnel with charges of rape and sexual violence to a limited extent and in conjunction with other crimes. ${ }^{56}$ Most notably, under the provision of failure to prevent atrocities and punish offenders under their command, which may be interpreted as a critical issue of command or superio' responsibility, General Iwane Matsui, Commander Shunroku Hata and Foreign Minister Kōki Hirota were found guilty of crimes-including that of rape. ${ }^{57}$

Despite this significant breakthrough and the fact that the Allies had volumes of evidence about the establishment and operation of the 'comfort stations, ${ }^{38}$ there was no attempt to recognize the criminal nature of the widespread use of rape and sexual violence by Japanese forces and to pursue accountability for the over two thousand 'comfort' women who were kidnapped, rounded up, coerced, lured, tricked and sold into prostitution to be used by the Japanese military as sexual outlets during the AsiaPacific War. ${ }^{5960}$ Neither were any charges brought for the mass rapes of ap-

54 Askin, "Prosecuting Wartime Rape." 37. Ibid.

55 Nicola Henry, "Memory of an Injustice: The 'Comfort Women' and the Legacy of the Tokyo Trial," Journal of Asian Studies Review 37.3 (2013), 362-380.

56 Richard J. Goldstone and Estelle A. Dehon, "Engendering Accountability: Gender Crimes under International Criminal Law," New England Journal of Public Policy 19.1 (2003), 121-145; Sellers, "The Prosecution of Sexual Violence in Conflict," 228.

57 Mike Ellis, "Breaking the Silence: Rape as an International Crime," Case Western Reserve Journal of International Law 28.3 (2006-2007), 225-227.

58 Dolgopol, "Knowledge and Responsibility;” Rumi Sakamoto, “The Women's International

War Crimes Tribunal on Japan's Military Sexual Slavery: A Legal and Feminist Approach to the 'Comfort Women' Issue," New Zealand Journal of Asian Studies 3.1 (2000), 49-58.

59 The 'comfort stations' were run by private operators that were supervised and maintained by the Japanese military, or run directly by the Japanese military. For more information about 'comfort stations' see Yoshimi Yoshiaki, Comfort Women: Sexual Slavery in the Japanese Military during World War II, (trans.) Suzanne O'Brien (New York, NY: Columbia University Press, 2002).

60 Henry, "Memory of an Injustice." It is unlikely that the prosecution of sexual slavery at the Tokyo Trials would have helped to clarify the parameters of what exactly constitutes sexual slavery, or the distinction between enforced prostitution as a 
proximately 100 Mapanique women in the Philippines in $1944 .{ }^{61} \mathrm{How}$ ever, some Japanese defendants were convicted of 'enforced prostitution' for forcing Dutch women into sexual servitude for the Japanese military during the war crimes trials in Batavia (Jakarta). ${ }^{62}$ In addition, General Tomoyuki Yamashita, commander of the $14^{\text {th }}$ Area Army of Japan was charged with the failure to control his troops who had committed widespread rape, murder, and pillage in Manila during the war. ${ }^{63}$ Despite his insistence that his troops were disorganized and he could not be held responsible for failing to control all under his authority, ${ }^{64}$ the Commission concluded that intentional ignorance could not be accepted as an explanation for the dereliction of official duty, that Yamashita was criminally responsible for failure of command responsibility and deserving of the death penalty. ${ }^{65}$ Conclusively then, while the Nuremberg and Tokyo trials were limited in the systematic prosecution of rape and sexual violence during WWII, their official recognition of such crimes as violations of the existing IHL at the time could be seen to lay the foundation for the developments that followed in the criminalization of rape and sexual violence during war. It is to this discussion that the chapter now turns.

war crime and as an example of gendered structural violence. See C. Sarah Soh, The Comfort Women: Sexual Violence and Postcolonial Memory in Korea and Japan (Chicago, Illinois: University of Chicago Press, 2009).

61 Sakamoto, “The Women's International War Crimes Tribunal on Japan’s Military Sexual Slavery;" Judgement on the Common Indictment and the Application for Restitution and Reparation (The Hague, The Netherlands, December 4, 2001), 91-95, http://www1.Jca.Apc. Org/Vaww-Net-Japan/English/Womenstribunal2000/Judgement.Pdf (accessed April 12, 2018).

62 See, for instance, Trial of Washio Awochi, Case No. 76, Netherlands Temporary Court-Martial at Batavia where a Japanese hotel/club/restaurant manager was found guilty of the war crime of enforced prostitution for forcing Dutch women into sexual servitude in his club between 1943-1945 (Judgment Delivered on October 25, 1946), http://www.Worldcourts.Com/Imt/Eng/Decisions/1946.10.25_Ne therlands_V_Awochi.Pdf (accessed April 12, 2018).

63 See In Re Yamashita, 327 U.S. 1 (1946), Justia, US Supreme Court, https://Suprem e.Justia.Com/Cases/Federal/Us/327/1/Case.Html (accessed April 12, 2018).

64 Askin, "Prosecuting Wartime Rape."

65 See supra note 61. 


\section{The Geneva Conventions and its Additional Protocols}

The systematic and willful slaughter and persecution of millions of civilians during WWII exposed the limitations of the protections offered by the original Geneva Conventions and underscored the need for their significant revision. ${ }^{66}$ The 1949 Geneva Conventions broke new grounds in providing protections to those hors de combat ('out of action') such as the shipwrecked, sick, the wounded, prisoners of war, and to civilians during wartime. This development, particularly relating to the Fourth Convention is extremely significant--given that the 1949 Geneva Conventions are a core constituent of contemporary conventional international law and are also part of universal customary law. The International Council of Women and the International Federation of Abolitionists were responsible for the inclusion of Article 27 of the Geneva Convention, which emphasizes the need for 'respect for fundamental rights, honor, family rights, religious convictions and practices, manners and customs, humane treatment and non-discrimination. ${ }^{67}$ Article 27 also grants special protection to women, prohibiting 'any attack on their honor, in particular against rape, enforced prostitution, or any form of indecent assault, ${ }^{68}$ and recognizes the specific kinds of violations that women have been subjected to during war including being forcibly entered into brothels and contaminated with venereal diseases. ${ }^{69}$ The Convention however, stopped short of including rape as among the grave breaches listed in Article $147^{70}$ and the travaux préparatoires do not indicate whether such crimes were considered for inclusion

66 The 1864 Geneva Convention was revised and expanded in 1906 and 1929. The 1949 Conventions supercede the earlier documents.

67 International Committee of the Red Cross (ICRC), https://Ihl-Databases.Icrc.Org/ Applic/Ihl/Ihl.Nsf/Vwtreaties1949.Xsp (accessed April 12, 2018).

68 Article 27, Convention (IV) Relative to the Protection of Civilian Persons in Time of War. Geneva, August 12, 1949, International Committee Of The Red Cross (ICRC), https://Ihl-Databases.Icrc.Org/Applic/Ihl/Ihl.Nsf/1a13044f3bbb5b8ec1256 $3 \mathrm{fb} 0066 f 226 / 25179 \mathrm{a} 620578 \mathrm{ad} 49 \mathrm{c} 12563 \mathrm{~cd} 0042 \mathrm{~b} 949$ (accessed April 12, 2018).

69 Ibid.

70 'Grave breaches' are the most serious international crimes which states are obligated to both prohibit and prosecute. 
among the grave breaches, although it has been argued that rape could be included among the grave breaches by implication. ${ }^{71}$

The Geneva Convention's Additional Protocols I and II, which entered into force on June 8, 1977 also broke new grounds with regard to the use of rape during wartime. Article 76(1) of Additional Protocol I, which applies to situations of international conflict, explicitly prohibits 'rape, forced prostitution and any other form of indecent assault, ${ }^{172}$ although it also does not include either rape or sexual violence among the grave breaches, which means it does not provide the pursue-and-prosecute obligation. ${ }^{73}$ Article 4(2)(e) of Protocol II, which explicitly governs conduct during non-international armed conflict, prohibits '[outrages upon personal dignity, in particular humiliating and degrading treatment, rape, enforced prostitution and any form of indecent assault; ${ }^{74}$ but is restricted in force because of the limited number of states that are parties to it. ${ }^{75}$ However, in both instances, rape is associated with crimes of honor and dignity rather than being characterized as a crime of violence, clearly highlighting the fact that when it came to issues of sexual violence, IHL was still dominantly informed by patriarchal norms.

\section{ICL, IHRL, Customary Law and Wartime Rape and Sexual Violence}

In addition to the developments in IHL, the substantive changes Geneva Conventions and the drafting of Additional Protocols I and II, both ICL and IHRL now provide certain protections to civilians during armed con-

71 Sellers, "The Prosecution of Sexual Violence," 9. See also Patricia Viseur Sellers, "Sexual Violence and Peremptory Norms: the Legal Value of Rape," Case Western Reserve Journal of International Law 34.3 (2002), 298.

72 Article 76 (1), Protection of Women, Protocol Additional to the Geneva Conventions of 12 August 1949, and Relating to the Protection of Victims of International Armed Conflicts (Protocol I), 8 June 1977, International Committee of the Red Cross (ICRC), https://Ihl-Databases.Icrc.Org/Applic/Ihl/Ihl.Nsf/1a13044f3bbb5b8 ec12563fb0066f226/933d8e1a38f44530c12563cd00436bc5 (accessed April 12, 2018).

73 Ibid.

74 Article 4 (2) (E) Protocol Additional to the Geneva Conventions of 12 August 1949, and Relating to the Protection of Victims of Non-International Armed Conflicts (Protocol II), Office of the United Nations High Commissioner for Human Rights (UNHCHR), http://www.Ohchr.Org/EN/Professionalinterest/Pages/Protoc olii.Aspx (accessed April 12, 2018).

75 Sellers, "Sexual Violence and Peremptory Norms," 299. 
flicts, including women and girls, some of which overlap. For instance, post WWII, rape gained recognition as an international crime, including as a crime against humanity as a result of the incorporation of international crimes into national military codes and national legislation. ${ }^{76}$ Both IHRL and IHL now prohibit torture and slavery, although the means and process of redress differ, with the latter requiring a connection to armed conflict. ${ }^{77}$ Today, ICL includes slavery and torture as serious violations, and serious human rights and IHL violations constitute international crimes. ${ }^{78}$

It is important to note that the non-derogable principle in IHRL and the protections they offer to civilians mean they cannot be suspended even in the context of armed conflict or a public emergency. For instance, Universal Declaration of Human Rights (UDHR), the International Covenant on Civil and Political Rights (ICCPR) both promises protections and upholds the principle of non-derogability when it comes to torture, slavery, and inhuman and degrading treatment. ${ }^{79}$ In addition, Askin notes that states are legally obligated to protect children from all forms of sexual assault and torture and respect IHL under the Convention on the Rights of the Children (CRC) ${ }^{80}$ The use of torture is also prohibited by the Convention Against Torture (CAT) even under exceptional circumstances, including 'a state of war, a threat of war, internal political instability or any other public emergency, may be invoked as a justification of torture. ${ }^{81}$ Extremely important for the issue of wartime rape and sexual violence, are the pro-

76 Sellers, "The Prosecution of Sexual Violence In Conflict."

77 See e.g. Prosecutor V. Kunarac Et. Al Judgement, (IT-96-23 \& 23/1), February 22, 2001, at paras 467-497. The Trial Chamber concluded that the definition of torture under IHL does not comprise the same elements as the definition of torture generally applied under HRL.

78 See, e.g. The Princeton Principles on Universal Jurisdiction, Princeton University Program In Law And Public Affairs, University of Minnesota, 2001, http://Hrlibra ry.Umn.Edu/Instree/Princeton.Html (accessed April 12, 2018).

79 Articles 7-8, International Covenant on Civil and Political Rights (ICCPR), December 16, 1966; entered into force on March 23, 1976, Office of the High Commissioner for Human Rights (OHCHR), Http://www.Ohchr.Org/En/Professionali nterest/Pages/Ccpr.Aspx (accessed April 15, 2018).

80 Articles 19, 34, 37, 39, Convention on The Rights of the Child (CRC), November 20, 1989; entered into force September 2, 1990, Office of the High Commissioner for Human Rights (OHCHR), http://www.Ohchr.Org/EN/Professionalinterest/Pa ges/CRC.Aspx (accessed April 15, 2018).

81 Article 2 (2), Convention Against Torture and Other Cruel, Inhuman or Degrading Treatment or Punishment, December 10, 1984; entered into force June 26, 1987. 
tections provided by the Convention on the Elimination of All Forms of Discrimination Against Women (CEDAW) which clearly prohibit discrimination and disparaging treatment on the basis of sex, which has been interpreted to include violence against women. ${ }^{82}$ The Declaration on Elimination of Violence Against Women (EVAW) now provides protections for women against all forms of violence including sexual violence during peacetime or armed conflict, in public and private spheres. ${ }^{83}$ In terms of regional protections, the Inter-American Convention on Violence ${ }^{84}$ and the Optional Protocol, which provides enforcements to ensure compliance with CEDAW, ${ }^{85}$ and the Protocol to the African Charter on Human and Peoples' Rights of Women in Africa of 2003 (Maputo Protocol), which prohibits violence against women and contains a number of provisions aimed at protecting women from sexual violence, are especially notable. ${ }^{86}$

There are several other protections that need to be mentioned. First, Common Article 2 to the 1949 Geneva Conventions clearly stipulates that the provisions of conventions do apply during times of conflict. ${ }^{87}$ The Martens Clause of The Hague Conventions asserts that fundamental hu-

82 Committee on the Elimination of Discrimination of Violence Against Women (CEDAW), December 18, 1979; entered into force September 3, 1981, Office of the High Commissioner for Human Rights (OHCHR), http://www.Ohchr.Org/E N/Hrbodies/CEDAW/Pages/Cedawindex.Aspx (accessed April 15, 2018).

83 Declaration on the Elimination of Violence Against Women, A/RES/48/104 December 20, 1993, http://www.Un.Org/Documents/Ga/Res/48/A48r104.Htm (accessed April 15, 2018).

84 Inter-American Convention on the Prevention, Punishment and Eradication of Violence Against Women 'Convention Of Belem Do Para,' Organization of American States (OAS), June 9, 1994, http://www.Oas.Org/Juridico/English/Treati es/A-61.Html (accessed April 15, 2018).

85 Optional Protocol to the Convention on the Elimination of All Forms of Discrimination

Against Women, GA Res. A/54/4, 54th Sess., Supp. No. 4, U.N. Doc. A (01)/R3, October 6, 1999; entered into force December 22, 2000. The Optional Protocol has a communications procedure that allows women to submit claims for violation of the Women's Convention. It also has an inquiry procedure which enables the CEDAW committee to initiate inquiries for gross violations when the state is a party to the Women's Convention and the Optional Protocol.

86 Articles 3(4), 4(2), 11(3), 12(1)(C)(D), 13(C), 14(2)(C), 22(B), 23(B), Protocol to the African Charter on Human and People's Rights on the Rights of Women in Africa (Maputo Protocol), July 11, 2003; entered into force November 25, 2005, http://www.Achpr.Org/Instruments/Women-Protocol/ (accessed April 15, 2018).

87 First, Second, Third and Fourth Geneva Conventions, Art. 2. The Conventions signed at Geneva on August 12, 1949, comprise of the Geneva Convention (I) for the Amelioration of the Condition of the Wounded and Sick in Armed Forces in 
man rights norms do not cease to be applicable during wartime..$^{88}$ Third, today genocide, torture, slavery, war crimes, crimes against humanity and sexual violence have reached the status of jus cogens (customary international law), which means that they cannot be committed under circumstances in any place ${ }^{89}$ and except for war crimes, do not require either a nexus to a conflict or a treaty ratification, meaning they can be prosecuted on the basis of universal jurisdiction. ${ }^{90}$

\section{Rape and Sexual Violence as Genocide: Establishing the Legal Framework}

The term 'genocide' did not exist during the time of the WWII and neither was it recognized as a legal crime during the time of the Nuremberg and Tokyo trials. The concept in fact was coined by lawyer Raphael Lemkin in 1944 in his book, Axis Rule in Occupied Europe. Lemkin, inspired by his knowledge of the large-scale orchestrated killing of the Armenians in the 1920s, the Assyrians in the Simele Massacre in Iraq in the 1930s, and the experiences of the Holocaust, argued that the Jewish identity of the victims were not emphasized when they were specifically targeted for ethnic cleansing by the Nazi regime. He then created a definition for the kind of heinous crime has the sole object of annihilating a nation or an ethnic

the Field, 6 U.S.T.3114, 75 U.N.T.S. 31 [hereinafter First Geneva Convention]; Geneva Convention (II) for the Amelioration of the Condition of Wounded, Sick and Shipwrecked Members of Armed Forces at Sea, 6 U.S.T. 3217, 75 U.N.T.S. 85 [hereinafter Second Geneva Convention]; Geneva Convention (I) Relative to the Treatment of Prisoners of War, 6 U.S.T.3316, 75 U.N.T.S. 135 [hereinafter Third Geneva Convention]; Geneva Convention (IV) Relative to the Protection of Civilian Persons in Time of War, 6 U.S.T. 3516, 75 U.N.T.S. 287 [hereinafter Fourth Geneva Convention]. The 1949 Geneva Conventions supersede the 1864, 1906, and 1929 Geneva Conventions.

88 The Martens Clause is found in several treaties relating to IHL. It is stated in the preamble of the 1899 and 1907 Hague Conventions. It also appears in the Second Additional Protocol to the Geneva Conventions as well as in the conventions adopted after 1977 . The clause is incorporated in the main body of the 1949 Geneva Conventions and the1977 Additional Protocols).

89 See, e.g. Jonathan I. Charney, "Universal International Law," The American Journal of International Law

87.4 (1993), 529-551; Jordan J. Paust et al., International Criminal Law (Durham, NC: Carolina Academic Press (4 ${ }^{\text {th }}$ edition), 2013).

90 Kelly D. Askin, "Prosecuting Wartime Rape." 
group. ${ }^{91}$ Although Lemkin worked with the American team to prepare for the Nuremberg trials, where he was able to get the term 'genocide' included in the indictment against Nazi leadership, since its legality was not yet established, and the verdict at Nuremberg did not cover peacetime attacks against groups, only crimes committed in conjunction with an aggressive war. ${ }^{92}$ Following four years of intense lobbying by Lemkin, on December 9, 1948, the UN approved of the Convention on the Prevention and Punishment of Genocide on December 9, 1948.

According to Article II of the present convention, genocide includes any of the following acts committed with intent to destroy, in whole or in part, a national, ethnical, racial or religious group, as such:

(a) Killing members of the group;

(b) Causing serious bodily or mental harm to members of the group;

(c) Deliberately inflicting on the group conditions of life calculated to bring about its physical destruction in whole or in part;

(d) Imposing measures intended to prevent births within the group;

(e) Forcibly transferring children of the group to another group. ${ }^{93}$

Furthermore, according to the Convention's Article III, the following crimes are punishable acts:

(a) Genocide;

(b) Conspiracy to commit genocide;

(c) Direct and public incitement to commit genocide;

(d) Attempt to commit genocide;

(e) Complicity in genocide.

Succinctly then, genocide is a different category from crimes against humanity in that while the latter may be committed against either an individual or any civilian, the former must be committed against members of a spe-

91 Raphael Lemkin, Axis Rule in Occupied Europe: Laws of Occupation, Analysis of Government, Proposals for Redress (Foundations of the Laws of War) (New Jersey: The Law Book Exchange, LTD, 1944), 79-82.

92 Coining a Word and Championing a Cause: The Story Of Raphael Lemkin, Holocaust Encyclopedia, United States Holocaust Memorial Museum, https:/www.Us hmm.Org/Wlc/En/Article.Php?Moduleid=10007050 (accessed April 20, 2018).

93 Convention on the Prevention and Punishment of the Crime of Genocide Approved and Proposed for Signature and Ratification or Accession by General Assembly Resolution 260 A (III) of December 9, 1948;

entry into force on January 12, 1951, in accordance with Article XIII, United Nations Human Rights Office of the High Commissioner, http://www.Ohchr.Org/E N/Professionalinterest/Pages/Crimeofgenocide.Aspx (accessed April 20, 2018). 
cific group with both the intent to destroy all or a part of protected group, and the underlying offense must have at least a remote chance of 'contribut[ing] to the complete or partial destruction of the victim's group. ${ }^{94}$ While crimes against humanity must be committed during armed conflict or as part of a widespread or systematic attack, genocide could be planned or committed on a large scale, or committed as an individual undertaking. ${ }^{95}$ Furthermore, while crimes against humanity can only target civilians, crimes of genocide may be committed against civilians or combatants. Finally, genocide can be committed only against those who belong to specifically protected groups characterized by their national, ethnic, racial or religious identity. 96

The incorporation of analysis that examines why and how acts of sexual violence are used in the context of conflict and violence against a woman and a community, which helps understand the intent of perpetrators and the consequences of such acts, help determine how such a crime can be categorized. ${ }^{97}$ In the context of attempting to establish the link between rape and sexual violence and genocide, international criminal jurisprudence requires an examination of how the former functions as a strategic method of the latter objective. ${ }^{98}$ Since genocidal rape occupies a different universe given that it carries a different type of message, there are important distinctions between the intent requirement to prosecute a sexual crime under the Genocide statute compared to that of domestic law. ${ }^{99}$ First, for a crime of rape or forced pregnancy to qualify as genocide, it is pertinent for the intent to destroy the group to accompany the intent to commit the underlying offense. ${ }^{100}$ In other words, in mens rea terms only 'when persecution escalates to the extreme form of wilful [sic] and deliberate acts designed to destroy a group or part of a group, [can it] be held that

94 Ibid., 303-304.

95 Ibid., 304.

96 Ibid.

97 Ibid.

98 Jonathan M. H. Short, "Sexual Violence as Genocide: The Developing Law of the International Criminal Tribunals and the International Criminal Court," Michigan Journal of Race and Law 8.2 (2005), 503-527.

99 Jonathan M. Short, "Sexual Violence as Genocide: The Developing Law of the International Criminal Tribunals and the International Criminal Court," Michigan Journal of Race and Law 8.2 (2003), 503-527.

100 Guenael Mettraux, "Crimes against Humanity in the Jurisprudence of the International Criminal Tribunals for the Former Yugoslavia and Rwanda," Harvard International Law Journal 43.1 (2002), 237-316. 
such persecution amounts to genocide, ${ }^{101}$ i.e. the woman was specifically targeted not just for her gender, but because of her role as part of an identifiable group. ${ }^{102}$ Succinctly, the intersectionality between gender and ethnicity becomes critical such that in the context of genocidal rape, 'certain women are being raped by certain men for particular reasons.' ${ }^{103}$

Genocidal rape can be manifest in specific ways. First, in contexts where perpetrators understand rape to be 'an effective method of isolating and humiliating women and men of the same culture, [the] isolation achieves effective genocide as it ... may mark women as "spoiled" and unsuitable for traditional marriage and family life.' 104 The bearing of an (unwanted) child created by this act of aggression by the perpetrator often also results in the rejection of the woman. Consider also enforced pregnancy, which can, through obstructing autonomous reproduction, inflict psychological trauma on an individual woman thereby preventing 'normal sexual or childbearing experiences with members of [her] own group' 105 while simultaneously denying her socioethnic group the 'benefit' of her procreative function since her womb is "occupied." 106 In most instances, the bearing of an (unwanted) child also results in the marking of the woman as being 'tainted' resulting in her social rejection, thereby both denying her ethnic group the benefit of accepting the woman, ${ }^{107}$ while fulfilling the objective of the perpetrator. Third, when the strategic calculation of

101 "In essence, genocide differs from persecution in that in the case of genocide, the perpetrator chooses his victims because they belong to a specific group and seeks to destroy in whole or in part this very group." Ibid., 296 (citing Prosecutor V. Kupregki, Case No. IT-95-16, Judgment 11 636, January 14, 2000).

102 Cassie Powell, "You Have No God': An Analysis of the Prosecution of Genocidal Rape in International Criminal Law," Richmond Public Interest Law Review 20.1 (2017), 26-48.

103 Sherrie L. Russell-Brown, "Rape as an Act of Genocide," Berkeley Journal of International Law 21.2, (2003), 350-374 (citing Catharine A. MacKinnon, "Crimes of War, Crimes of Peace," UCLA Women's Law Journal 4.1 (1993), 59-86.

104 Sarnata Reynolds, "Deterring and Preventing Rape and Sexual Slavery During Periods of Armed Conflict," Law \& Inequality: A Journal of Theory and Practice 16.2 (1998), 601-632 (citing Ruth Seifert, "War and Rape: A Preliminary Analysis," Mass Rape: The War Against Women in Bosnia-Herzegovina ed. Alexandra Stiglmayer (Lincoln, NE: University of Nebraska Press, 1994), 59).

105 Siobhan K. Fisher, "Occupation of the Womb: Forced Impregnation as Genocide,” Duke Law Journal, 46.1 (1996), 93.

106 Ibid (noting that "their own children" refers to the children of the "group" of the mother. This might be especially true in societies in which the ethnicity of children is determined by the father).

107 Ibid. 
the perpetrating group is to not only impede but also annihilate members of the targeted community through reducing the birthrate, then as Short argues, it is imperative to identify and prosecute the sexual violence in question in terms of genocide. ${ }^{108}$ Fourth, in patriarchal societies where ethnicity of the child is determined by the ethnicity of the father, mass rape to elicit forced impregnation may be deemed as essentially leading to the destruction of the ethnic group. This was certainly the case in former $\mathrm{Yu}$ goslavia with regard to the Bosnian population, where lineage and cultural identity is inherited through patrilineal lines, and where forced pregnancy was used to dilute the Muslim identity leading to the subsequent rejection of the child forcibly conceived. Forced displacement, especially if a particular place is tied to one's culture or ethnicity, may also be considered genocidal given that it "deliberately inflicts on the group conditions of life calculated to bring about its physical destruction in whole or in part"109 through compelling them to flee their homes and leave the territory." 110 Powell argues that the deliberate transference of sexually transmitted diseases (STDs) as happened in the case of Rwanda where approximately 70 per cent of the Tutsi women contracted HIV (and later died from it) ${ }^{111}$ as a consequence of the weaponization of a life-threatening disease spread by rapists constituted a genocide since "rape became a slow murder weapon, inflicted to destroy a group." 112 Since Article II(b) of the Genocide Convention forbids acts committed with an intent to destroy a particular group, in whole or in part, by causing "serious bodily or mental harm" to members of the group, the use of sexual assault which constitutes both physical and psychological harm, rape can therefore be considered an instrument of genocide. Summarily then, "[s]exual assault meets the elements of genocide or when committed in massive proportions in an attempt to destroy a particular group, even when committed to harm a single woman who is a member of the protected group." 113 These developments in legal jurisprudence regarding rape and sexual violence as war crimes, crimes against humanity and genocide became central to the political events of the 1990s.

108 Short, "Sexual Violence as Genocide."

109 Powell, "You Have No God," 16.

110 Kelly D. Askin, War Crimes Against Women: Prosecution in International War Crime Tribunals (The Hague: Martinus Nijhoff Publishers, 1997), 339.

111 Peter Landeman, “A Woman's Work”, The New York Times Magazine, September 15, 2002.

112 Powell, "You Have No God," 41.

113 Askin, War Crimes Against Women, 342. 
In the violent conflicts that broke out in the early 1990s in both former Yugoslavia and in Rwanda, sexual violence against women was used on a large-scale to 'humiliate, subordinate, or emotionally destroy entire communities; to cause chaos and terror; to make people flee; and to ensure the destruction or removal of an unwanted group by forcible impregnation by a member of a different ethnic group.'114 Such crimes were genocidal in nature not only because they targeted women but because they were particularly instrumentalized frequently for the purpose of committing ethnic cleansing. ${ }^{115}$ While international involvement in both contexts was heavily criticized for their inability to halt the violence and save lives, building off of the legacy of Nuremberg and Tokyo, it also resulted in the establishment of two ad hoc tribunals, both of which played a monumental role in breaking the silence on wartime rape and sexual violence as an international crime, and resulted in the development of legal jurisprudence on such violations as a war crime and a crime against humanity. ${ }^{116}$ Critical for this discussion, the tribunals also broke new ground in developing and strengthening jurisprudence on crimes as instruments of genocide through a series of key judgements, ${ }^{117}$ particularly notable since prior to the $1990 \mathrm{~s}$ international law had failed to clearly articulate the elements necessary for the effective prosecution of rape and sexual violence. Subsequently, the tribunals had to develop their own definitions of rape, both in terms of mens rea and actus rea and in doing so were the two main engines responsible for the contemporary evolution of rape and sexual violence jurisprudence. ${ }^{118}$ It is worth noting that the latter may be considered even more revolutionary given that prosecution of gender-based sex crimes at the tribunals were fraught with enormous challenges, and their investigation and subsequent successful indictments were largely due to the ongoing con-

114 Jocelyn Campanaro, "Women, War, and International Law: The Historical Treatment of Gender-based War Crimes," Georgetown Law Journal 89 (2001), $2557-2570$.

115 Ibid.

116 Sellers, "The Prosecution Of Sexual Violence."

117 Ellis, "Breaking the Silence," 229.

118 David S. Mitchell, "The Prohibition of Rape in International Humanitarian Law as a Norm of Jus Cogens: Clarifying the Doctrine," Duke Journal of Comparative and International Law 15 (2005), 219-258. 
certed pressure applied by women's rights organizations and feminist scholars to ensure their prosecution. ${ }^{119}$

The ICTY for instance broke new grounds with the Celebici Case where it set precedence with regard to gender-based sex crimes, most notably with regard to the question of superior responsibility, use of sexual violence against male detainees, and the use of rape as a means of torture. ${ }^{120}$ The recognition of sex-based crimes against men and boys is significant given that while IHL has always privileged men's experiences in war, it has been an incomplete account of men's experiences of conflict because it has not explicitly considered men as potential rape victims. ${ }^{121}$ In finding rape as a form of torture, the Trial Chamber adopted the elements of torture in the Convention Against Torture (CAT), and stipulated that when any form of sexual violence satisfies these elements, it may constitute torture. ${ }^{122}$ The prosecution also indicted the accused of unlawful confinement of civilians, willfully causing great suffering, cruel treatment, willful killing, murder, torture, inhuman treatment, and plunder as part of the charges of the commission of war crimes. ${ }^{123}$ The precedent from this case can be used, 'inter alia, to hold superiors criminally liable for failing to adequately train, monitor, supervise, control, and punish subordinates who commit rape crimes.' ${ }^{124}$ On February 2001, ICTY handed down the Kunarac Judgement, on what was yet another ground-breaking case, given it was the first time that the Court was prosecuting and convicting individuals for rape as a crime against humanity as per articles $5(\mathrm{~g})$ and 3 of the Yugoslavia Tribunal statute and getting the first ever conviction for sexual enslavement in conjunction with rape. ${ }^{125}$ Referred to as the 'rape camp' case, it brought

119 K. Alexa Koenig, Ryan Lincoln and Lauren Groth, "The Jurisprudence of Sexual Violence," Sexual Violence and Accountability Project Working Paper Series (Human Rights Center, University of Berkeley, May 2011).

120 See Prosecutor V. Zejnil Delali, case no., IT-96-21-T, November 16, 1998, at para 394, http://www.icty.org/x/cases/mucic/tjug/en/cel-tj981116e.pdf (accessed April 20, 2018) [hereinafter the Delali Judgement].

121 Laetitia Ruiz, "Gender Jurisprudence for Gender Crimes?" International Crimes Database Brief 20 (June 2016), http://www.internationalcrimesdatabase.org/uploa d/documents/20160701T104109-ICD\%20Brief\%2020\%20-020Ruiz.pdf (accessed April 17, 2018).

122 Prosecutor V. Delali, Judgement, IT-96-21-T, 16 Nov. 1998 [hereinafter Celebici Trial Chamber Judgement], at para 496.

123 Kelly D. Askin, "Prosecuting Wartime Rape."

124 Ibid., 327.

125 Crimes against humanity differ from war crimes by, among other things, not requiring a nexus to armed conflict. Prosecutor v. Dragoljub Kunarac, Radomir Kovac and Zoran Vukovic Judgment, case no. It-96-23/1- t, February 22, 2001. 
charges against three defendants who had participated in systematic sexual violence against Muslim women that included maintaining a detention center and other facilities in which women and girls were routinely raped as part of a military campaign to cleanse the Foça municipality in the Republika Srpska. ${ }^{126}$ In the Judgement, each defendant was charged and found guilty of various forms of gender-related crimes, including rape, torture, enslavement, and outrages upon personal dignity. The Kunarac Judgement provided a different definition of rape than the one established in Furundzija trial as it included, for the first time, an 'explicit and affirmative inquiry into the consent of the victim rather than an inquiry into the presence of force or coercion, which would imply non-consent. ${ }^{127128}$ In offering a definition of rape, the Judgement also focused attention on the importance of consent, noting that the Furundzija definition did not 'refer to other factors which would render an act of sexual penetration non-consensual or non-voluntary on the part of the victim. ${ }^{129}$ Furthermore, the Trial Chamber underscored that the emphasis must be placed on violations of sexual autonomy because 'the true common denominator which unifies the various systems may be a wider or more basic principle of penalising violations of sexual autonomy. ${ }^{130}$ The Chamber also found that any time a person has not freely agreed to an act voluntarily, sexual autonomy is violated ${ }^{131}$ and force, threat, or taking advantage of a vulnerable person pro-

126 Ibid; press release, International Criminal Tribunal for the Former Yugoslavia, Judgment of Trial Chamber II in the Kunarac, Kovac and Vukovic case, February 22, 2001.

127 The Kunarac definition remained the prevailing standard in both the Rwanda and Yugoslavia tribunals prior to the Appeal of Prosecutor V. Gacumbitsi, although there were some cases in which the earlier Akayesu definition of rape was favored and applied.

128 Koenig, Lincoln and Groth, "The Jurisprudence Of Sexual Violence."

129 The objective elements of rape articulated in Furundzija consisted of (I) the sexual penetration, however slight:

(a) of the vagina or anus of the victim by the penis of the perpetrator or any other object used by the perpetrator; or

(b) of the mouth of the victim by the penis of the perpetrator;

(ii) by coercion or force or threat of force against the victim or a third person. Prosecutor V. Furundzija, case no.

IT-95-17/1-T, December 10, 1998, at para. 438, http://www.icty.org/x/cases/furun dzija/tjug/en/fur-tj981210e.pdf (accessed April 20, 2018) [hereinafter Furundzija Judgement].

130 Ibid., para. 440 (emphasis in original).

131 Ibid., para 457. 
vide evidence as to whether consent is voluntary. ${ }^{132}$ In addition, it identified three broad categories of factors to determine when sexual activity should be classified as rape including when (i) sexual activity is accompanied by force or the threat of force to the victim or a third party; (ii) the sexual activity is accompanied by force or a variety of other specified circumstances which made the victim particularly vulnerable or negated her ability to make an informed refusal; or (iii) the sexual activity occurs without the consent of the victim. ${ }^{133}$

Article 4 of the ICTY Statute and Article 2 of the ICTR Statute granted the respective tribunals jurisdiction over genocide, paving the way for the prosecution of rape and sexual violence as acts of genocide for the first time in the international criminal sphere. It is to this discussion the chapter now turns.

\section{The Akayesu Judgement}

On September 2, 1998 the ICTR Trial Chamber handed down the Akayesu Judgement against Jean-Paul Akayesu, bourgmestre (akin to mayor) of the Taba commune in Rwanda. While Akayesu was originally charged with 12 counts of genocide, crimes against humanity, and war crimes for the murder, extermination, torture, and cruel treatment committed throughout $T a b a$, initially he did not face any charges for gender-related crimes. However, based on an investigation that revealed extensive evidence of sexual violence committed by Hutu men against Tutsi women, the prosecution amended the indictment to charge Akayes $u$ with rape and other inhumane acts' as crimes against humanity and war crimes in Counts 13-15 of the Amended Indictment. It is worth nothing that the Akayesu trial was the first case to identify the elements of rape ${ }^{134}$ where the accused was charged with rape both as a crime against humanity and a genocide in an international setting. ${ }^{135136}$

The Akayesu Trial Chamber Judgement was monumental for several reasons. First, the Judgement marks a significant legal victory-it found

132 Ibid., para 458.

133 Ibid., para 459.

134 See The Prosecutor v. Jean-Paul Akayesu, case no. ICTR-96-4-T, September 2, 1998, at paras 685-696, http:/unictr.unmict.org/sites/unictr.org/files/case-documents/i ctr-96-4/trial-judgements/en/980902.pdfn [hereinafter Akayesu Judgement).

135 Ibid., at paras 696, 734 .

136 Kelly D. Askin, "Prosecuting Wartime Rape." 
Akayesu criminally responsible for aiding and abetting and for 'verbally encouraging' the commission of nine of the 15 counts charged against him in the Amended Indictment, including charges of genocide and the crimes against humanity of extermination, murder, torture, rape, and other inhumane acts. ${ }^{137}$ Second, it found that the rape of Tutsi women was systematic and was perpetrated against all Tutsi women and solely against them ... [a]s part of the propaganda campaign geared to mobilizing the Hutu against the Tutsi ...' ${ }^{138}$ Furthermore, the Chamber concluded that '[the] sexualized representation of ethnic identity graphically illustrates that $[T] u t s i$ women were subjected to sexual violence because they were Tutsi. Sexual violence was a step in the process of destruction of the [T]utsi group-destruction of the spirit, of the will to live, and of life itself. ${ }^{\prime} 39$ The use of rape and sexual violence by Hutu perpetrators against the Tutsi therefore met the statutory requirements for a finding of genocide. ${ }^{140}$ Conclusively then, the Akayesu judgement 'took the first step in breaking down the international legal community's ambivalence toward rape and sexual violence as crimes under international law. ${ }^{141}$ Correspondingly, the linking of rape to genocide in the Akayesu case became the first ever time that allowed gender based violence, to be specifically prosecuted as a violation of the highest order in international criminal law and was the first ever conviction of either genocide or crimes against humanity for sexual violence.

Beyond the specificities of the Akayesu trial what was perhaps even more groundbreaking was the legal precedence it set in terms of offering seminal definitions of rape and sexual violence in ICL and creating the grounds for trying such crimes as instruments of genocide and crimes against humanity. For instance, the Trial Chamber produced the first genocide conviction for sexual violence based on sub-element (i) with the intent of killing members of a group; ${ }^{142}$ sub-element (ii) constituting serious bodily or mental harm; ${ }^{143}$ as well as (iii) be comprised of measures intended to prevent births within the group; ${ }^{144}$ and (iv) amount to forcibly transferring children of

137 Akayesu Judgement, at para 724.

138 Ibid., at para 732 .

139 Ibid.

140 Ibid.

141 Alex Obote-Odora, "Rape and Sexual Violence in International Law," New England Journal of International and Comparative Law 12.1 (2005), 137.

142 Akayesu Judgment, at para 733.

143 Ibid., at para 731.

144 Ibid., at para 507 (including acts such as sexual mutilation, sterilization, forced birth control, separation of the sexes and prohibition of marriages). 
the group to another group. ${ }^{145}$ In so doing, it offered guidance for future tribunals applying the sub-elements of genocide to cases involving sexual assault. ${ }^{146}$ The Akayesu Trial Chamber also noted that while national jurisdictions have historically defined rape as 'non-consensual sexual intercourse,' a broader definition was warranted to include 'acts which involve the insertion of objects and/or the use of bodily orifices not considered to be intrinsically sexual ...' and as such the act of 'thrusting a piece of wood into the sexual organs of a woman as she lay dying- constitutes rape in the Tribunal's view.' ${ }^{147}$ The Trial Chamber emphasized that the amount of coercion required does not need to amount to physical force, as '[ $t]$ hreats, intimidation, extortion and other forms of duress which prey on fear or desperation may constitute coercion, ${ }^{148}$ and that coercion may be inherent in armed conflict situations or when military personnel, such as militia, are present. ${ }^{149}$ In addition, the Chamber defined sexual violence as 'any act of a sexual nature which is committed on a person under circumstances which are coercive and that it fell within the scope of "other inhumane acts" as crimes against humanity, "outrages upon personal dignity" of the war crime provisions of the Statute, and "serious bodily or mental harm" of the genocide prescriptions. ${ }^{150}$ Furthermore, 'sexual violence is not limited to physical invasion of the human body and may include acts which do not involve penetration or even physical contact.' ${ }^{151}$ The Chamber also recognized forced nudity as a form of sexual violence constituting inhumane acts as crimes against humanity even if it did not involve touching. Last but not the least, the Judgement unambiguously recognized that sexual violence causes extensive harm, and it is intentionally used during periods of mass violence to subjugate and devastate a collective enemy group and that in the genocidal regime carried out by Hutus, rape crimes were perpetrated as 'an integral part of the process of destruction. ${ }^{152}$ In so doing, the Court emphasized that the injury and suffering inflicted by sexual violence extends beyond the individual to the collective targeted group, in this case,

145 Ibid., at para 509.

146 Shayna Rogers,"'Sexual Violence or Rape as a Constituent Act of Genocide: Lessons From the Ad Hoc Tribunals and a Prescription for the International Criminal Court," The George Washington International Law Review 48.2 (2016), 265-278.

147 . Akayesu Judgement, at para 686.

148 Ibid., at para 688.

149 Askin, "Prosecuting Wartime Rape."

150 Akayesu Judgement, at para 688.

151 Ibid.

152 Ibid., at para 731. 
the Tutsis. ${ }^{153}$ Succinctly, the Akayesu Trial Chamber recognized 'that the constituent act of preventing births within the group includes measures such as forced sterilization, abortion, or birth control, as well as forced pregnancy where, in patriarchal societies, that represents an effort to affect ethnic composition by imposing the enemy's ethnicity on the children of rape. ${ }^{154} \mathrm{In}$ addition, by stating ' $[\mathrm{r}] \mathrm{ape}$, with its potential to cause infertility or make sexual intercourse impossible, as well as its potential to render a woman psychologically or culturally unable to reproduce, may also qualify, as a measure intended to prevent births within the group, ${ }^{155}$ the Judgement recognized the connection between attacks on reproduction and the intent to commit genocide. ${ }^{156}$

Four months after the Akayesu Judgement, on December 1998, in the Furundzija Judgment, an ICTY Trial Chamber convicted a Special Forces commander for rape and torture as war crimes under Common Article 3 of the Geneva Convention, as recognized under Article 3 of the ICTY Statute. It found that in this case that the elements of rape were: (i) sexual penetration, however slight: of the vagina or anus of the victim by the penis of the perpetrator or any other object used by the perpetrator; or of the mouth of the victim by the penis of the perpetrator; (ii) by coercion or force or threat of force against a victim or third person. ${ }^{157}$ Two of the most important contributions of the case were (i) recognizing sexual violence as a form of torture; and (ii) rejecting the notion that female Judges with gender advocacy backgrounds are inherently biased against men accused of rape crimes. ${ }^{158}$ While in the Furundzija case the elements of rape were different from the Akayesu definition in its mechanical physiological approach and its inclusion of the gender neutral use of third persons, ${ }^{159}$ both definitions deliberately abstained from discussing the non-consent of the

153 Askin, "Prosecuting Wartime Rape."

154 Rhonda Copelon, "Gender Crimes as War Crimes: Integrating Crimes against Women into International Criminal Law," McGill Law Journal (2000), 217, 224 (citing Shattered Lives: Sexual Violence During the Rwandan Genocide and its Aftermath, 1996, 94 (1996), http://Ww $\backslash$ Xhr-IWorg/Reports/1 996/Rwanda.Htm), 227-228. See Akayesu Judgment, 507.

155 Ibid., 228.

156 Short, "Sexual Violence As Genocide."

157 Furundzija Judgment, at para. 18.

158 Askin, "Prosecuting Wartime Rape."

159 Sellers, "The Prosecution Of Sexual Violence In Conflict." 
victim as a prerequisite to the commission of rape. ${ }^{160}$ Moreover, the $F u$ rundzija Trial Chamber underscored that 'any form of captivity impaired the legal validity of consent. ${ }^{161}$ Similar to the Akayesu definition, the essential elements of the Furundzija definition of rape were not challenged nor reversed on appeal. ${ }^{162}$ The Prosecutor $v$. Musema case that was tried two years later affirmed much of the jurisprudence established in Akayesu. ${ }^{163}$ The idea that rape and other acts of sexual violence meet the standard of serious bodily and mental harm element of genocide have been confirmed by the Trial Chambers in Kayishema, Musema, Krstić, Kamuhanda, Stakic, Kajelijeli, and Gacumbitsi. ${ }^{164}$ In the Kayishema case, the Trial Chamber concluded that there is a connection between rape and another actus reus for genocide-deliberately inflicting on the targeted group conditions of life calculated to bring about its physical destruction in whole or in part. ${ }^{165}$

160 See Anne-Marie de Brouwer, Supranational Criminal Prosecution of Sexual Violence: The ICC and the Practice of the ICTY and the ICTR (Antwerp, Belgium: Intersentia, 2005).

161 Furundzija Judgement, at para. 271.

162 Sellers, "The Prosecution Of Sexual Violence In Conflict."

163 Prosecutor V. Alfred Musema, case no. ICTR-96-13-T, January 27, 2000, http://hrlib rary.umn.edu/instree/ICTR/MUSEMA_ICTR-96-13/MUSEMA_ICTR-96-13-A.ht $\mathrm{ml}$ (accessed April 27, 2018) [hereinafter the Musema Judgement].

164 Prosecutor V. Clément Kayishema and Obed Ruzindana, case no. ICTR-95-1-T, May 21, 1999, at para 108, http://www.worldcourts.com/ictr/eng/decisions/1999. 05.21_Prosecutor_v_Kayishema_1.pdf (accessed April 27, 2018 ) [hereinafter Kayishema Trial Judgment]; Musema Judgement, at para 156; Prosecutor V. Radislav Krstić, case no. IT-98-33, August 2, 2001, at paras, 509, 513, http://www.i cty.org/x/cases/krstic/tjug/en/krs-tj010802e.pdf (accessed April 27, 2018) [hereinafter Krsti Judgment]; Prosecutor V. Jean de Dieu Kamuhanda, case no. ICTR-97-23-S, September 4, 1998, at para. 634, http://hrlibrary.umn.edu/instree/IC TR/KAMUHANDA_ICTR-99-54/KAMUHANDA_ICTR-95-54A-T.html (accessed April 27, 2018) [hereinafter Kamuhanda Judgment]; Prosecutor V. Milomir Stakic, case no. IT-97-24, July 31, 2003, at para 516, http://www.icty.org/x/cases/st akic/acjug/en/sta-aj060322e.pdf (accessed April 27, 2018) [hereinafter Stakic Judgment]; Prosecutor V. Juvénal Kajelijeli, case no. ICTR-98-44A-T, December 1, 2003, at para 815, http://hrlibrary.umn.edu/instree/ICTR/KAJELIJELI_ICTR-9 8-44A/KAJELIJELI_ICTR-98-44A-T.pdf (accessed April 27, 2018) [hereinafter Kajelijeli Judgment]; Prosecutor V. Sylvestre Gacumbitsi, case no. ICTR-2001-64-T, June 17, 2004, at para 291, http://hrlibrary.umn.edu/instree/ICTR/GACUMBITS I_ICTR-01-64/GACUMBITSI_ICTR-2001-64-A_appeals.pdf (accessed April 27, 2018) [hereinafter Gacumbitsi Judgment].

165 Angela M. Banks, "Sexual Violence and International Criminal Law: An Analysis of the Ad Hoc Tribunal's Jurisprudence \& The International Criminal Court's Elements Of Crimes," (College of William \& Mary Law School, 2005), http://scholarship.law.wm.edu/facpubs/305 (accessed April 27, 2018). 
Such treatment was ruled to include 'circumstances which will lead to a slow death, for example, lack of proper housing, clothing, hygiene and medical care or excessive work or physical exertion. ${ }^{166}$ The Trial Chamber also concluded that since the intentional infliction of conditions of life for the purpose of a group's destruction in whole or in part can also include rape, since such deliberate measures may not immediately result in the annihilation of the members of the group. ${ }^{167}$ The accused in the case were convicted of genocide based on killing and causing serious bodily and mental harm as substantiated by the evidence of rape and mutilations. ${ }^{168}$ In the Niyitegeka case, the Trial Chamber established the question of the accused's intent regarding the use of rape and sexual violence to destroy in whole or in part a national, racial, religious or ethnic group when ruling that 'ordering Interahamwe to undress a Tutsi woman, and to insert a sharpened piece of wood into her genitalia, after ascertaining that she was of the Tutsi ethnic group and leaving the body with the piece of wood protruding from it, in plain view on a public road for some three days thereafter.' ${ }^{169}$ In the Mubimana case, given that the accused apologized to a young girl he raped after he realized that she was Hutu and not Tutsi and to have specifically referred to the Tutsi identity of his victims, ${ }^{170}$ the Trial Chamber concluded that he intended to destroy, in whole or in part, the Tutsis, by shooting and raping them. ${ }^{171}$

Despite these promising cases however, Powell has argued that progress in prosecuting genocidal rape in the ICTR effectively stopped after the Akayesu judgement and may be considered at times to have even regressed. ${ }^{172}$ Although as noted above there were several convictions for genocidal rape, rape was eventually redefined more narrowly, limiting she concludes, the ability of the Office of the Prosecutor to prosecute it in generall $^{173}$ as for instance in the Furundzija case, where the court's redefinition

166 Kayishema Judgement, at paras 108, 115.

167 Ibid., at paras 116, 547.

168 Ibid., at para 547.

169 Prosecutor V. Eliézer Niyitegeka, case no. ICTR-96-14-T, May 16, 2003, at para 416, http://unictr.unmict.org/sites/unictr.org/files/case-documents/ictr-96-14/trial-jud gements/en/030516.pdf (accessed April 27, 2018) [hereinafter Niyitegeka Judgment].

170 Prosecutor V. Mikaeli Muhimana, case no. ICTR-95-1-I, April 28, 2005, at para 517, http://www.refworld.org/cases,ICTR,429c29694.html (accessed April 27, 2018) [hereinafter Mubimana Judgment].

171 Ibid., para 518.

172 Powell, "You Have No God."

173 Ibid. 
of rape as 'penetration' rather than 'invasion,'174 limited the scope of crimes that could be prosecuted as rape. ${ }^{175}$ Similarly, in Prosecutor v. Kunarac, Powell argued that by requiring the Prosecutor demonstrate that the victim did not consent to the rape, the ICTY took a further step back, ultimately narrowing the Akayesu judgement's impact on future cases, while simultaneously limiting the ability of the Prosecutor to obtain convictions for rape crimes. ${ }^{176}$

\section{A Bridge Too Far? Trying Rape and Sexual Violence as Genocide at the ICC}

A little more than 50 years since the establishment of the Nuremberg Charter, the international community assembled at the 1998 Rome Conference to establish the International Criminal Court (ICC), the first permanent international court with the jurisdiction to adjudicate over matters of individual criminal culpability in the event of commission of war crimes, crimes against humanity, genocide, and as of July 2018, crimes of aggression. Established on the doctrine of complimentarity and recognized as the 'court of last resort,' it is irrefutably an unprecedented mechanism established with the broadest mandate (ICTY and ICTR had jurisdiction over persecution on political, racial and religious grounds only) to try cases of persecution against 'any identifiable group or collectivity on political, racial, national, ethnic, cultural, religious, gender [emphasis added] as defined in paragraph 3, or other grounds that are universally recognized as impermissible under international law, in connection with any act referred to in this paragraph or any crime within the jurisdiction of the Court.' 177

Although within the Rome Statute the crime of genocide does not explicitly mention rape, its definition has been considered sufficiently broad to include rape as an act that constituted genocide. Most importantly perhaps, the inclusion of gender in the Rome Statute has meant that for the first time in international law and in the history of international courts, it became possible to expansively prosecute gender- related crimes. In fact, Rome Statute, and ICC's Rules of Procedure and Evidence and the Ele-

174 Furundzija Judgement.

175 Powell, "You Have No God."

176 Ibid.

177 Rome Statute of the International Criminal Court, July 17, 1998, Article 7(1) $(\mathrm{H})$, https://www.icc-cpi.int/nr/rdonlyres/ea9aeff7-5752-4f84-be94-0a655eb30e16/0/ro me_statute_english.pdf (accessed April 28, 2018) [hereinafter Rome Statute]. 
ments of Crimes, 'are the first international instruments to independently enumerate and define a range of sexual and reproductive crimes relating specifically to women and gender. ${ }^{178}$ In so doing, these documents break new grounds in terms of the expansive definition of sexual violence through including sexual slavery, enforced prostitution, forced pregnancy, enforced sterilization and other forms of sexual violence of equivalent gravity to the list of war crimes and crimes against humanity. ${ }^{179}$ The Statute further acknowledges that sexual violence targets both men and women, and confirmed that defendants could and should be held liable for their own actions as well as for command responsibility in the event their inferiors or partners have violated the rules of war under their authority. ${ }^{180}$ Two additional critical elements of the ICC regarding its recognition of rape and sexual violence need to be mentioned. First, it recognizes the premise of joint criminal enterprise in Article 25 (3) (d) ${ }^{181}$ and the role of command responsibility under article 28 , where it explicitly holds military commanders and others responsible for the actions of their subordinates, an issue that has been an ongoing issue of judicial deliberation since Nuremberg and Tokyo. ${ }^{182}$ Koenig, Lincoln and Groth succinctly point out the importance of command responsibility in the context of sexual violence, given that

those who physically commit the crimes are often relatively low on the chain of command and thus fall outside the Court's mission to ensure accountability at the highest levels ... [and] command responsibility as an approved mode of liability improves the likelihood that sexual violence can be recognized as a tool of warfare and not just a random

178 Kristen Boon, "Rape and Forced Pregnancy Under the ICC Statute: Human Dignity, Autonomy, and Consent," Columbia Human Rights Law Review 32 (2001), 630.

179 See Rome Statute, Articles 7 and 8; De Brouwer, "Supranational Criminal Prosecution Of Sexual Violence."

180 De Brouwer, "Supranational Criminal Prosecution", 338.

181 "A person shall be criminally responsible and liable for punishment for a crime within the jurisdiction of the Court if that person: (a) commits such a crime, whether as an individual, jointly with another or through another person, regardless of whether that other person is criminally responsible ... [or that] (d) in any other way contributes to the commission or attempted commission of such a crime by a group of persons acting with a common purpose." Rome Statute, Article 25 (3) (d).

182 Rome Statute, Article 28 (A). 
crime of opportunity, and thus as an act either directly or indirectly encouraged by leaders. ${ }^{183}$

Second, there are now specific procedural rules about how to deal with such crimes in the Court. In this regard, Rule 63 of the ICC breaks from the historic practice of determining that a woman's word was not sufficient evidentiary weight to establish rape on its own, by declaring that the Chambers cannot require corroboration to prove any crime within the Court's jurisdiction, particularly crimes of sexual violence. ${ }^{184}$ In addition, Rule 70 deals with the controversial issue of 'consent' as a defense for rape, recognizing that repeatedly interrogation of a victim in court about her/his 'consent' to sexual activity ultimately 'blames and re-traumatizes the victim. ${ }^{.185}$ The resulting Rule 72 establishes that

[w] here there is an intention to introduce or elicit, including by means of the questioning of a victim or witness, evidence that the victim consented to an alleged crime of sexual violence, or evidence of the words, conduct, silence or lack of resistance of a victim or witnesses ... [n]otification shall be provided to the Court which shall describe the substance of the evidence intended to be introduced or elicited and the relevance of the evidence. ${ }^{186}$

Furthermore, in keeping with the decision of the ICTY, Rule 71 of the ICC prohibits the introduction of prior sexual conduct regarding any case relating to rape and sexual violence although it also prohibits the introduction of subsequent sexual conduct. ${ }^{187}$

Outside of the development of legal jurisprudence, the ICC has also broken new ground in creating a participatory platform for victims, particularly women in its proceedings as a result of concerted effort and lobbying by civil law countries to allow victims to have extensive participatory rights. ${ }^{188}$ Today, except for the victim participation scheme adopted by the Extraordinary Chambers in the Courts of Cambodia (ECCC), the ICC has

183 Koenig, Lincoln and Groth, "The Jurisprudence of Sexual Violence," 21.

184 Rome Statute, Article 63 (4).

185 Rules of Procedure and Evidence, ICC-ASP/1/3, September 2002, Rule 70, 24 https:/www.icc-cpi.int/NR/rdonlyres/F1E0AC1C-A3F3-4A3C-B9A7-B3E8B115E 886/140164/Rules_of_procedure_and_Evidence_English.pdf (accessed July 10, 2018) [hereinafter ICC Rules of Procedure and Evidence].

186 Ibid., Rule 72, 24.

187 Ibid., Rule 71, 24.

188 See the Coalition for the International Criminal Court http://www.coalitionfort heicc.org (accessed July 10, 2018). 
the broadest victim participation and protection scheme of any previous tribunal. Specifically, the Rome Statute's article 8(1) explicitly considers special protection for victim witnesses including for survivors of sexual and gender-based violence. To safeguard anonymity and confidentiality, the ICC withholds witness identities from the public if necessary and uses electronic and other means to protect them. ${ }^{189}$ For extremely vulnerable witnesses, the Rome Statute requires the court prosecutor to 'appoint advisors with legal expertise on specific issues, including sexual and gender violence. ${ }^{190}$ The ICC also has a Victims and Witnesses Unit and a Gender and Child Unit in the Office of the Prosecutor to help the prosecution adequately address the specific issues faced by victims of sexual violence. ${ }^{191}$ Furthermore, the ICC includes a Trust Fund for Victims, which is responsible for assisting victims, implementing court orders post-conviction, including coordinating and managing reparations (restitution, compensation and/or rehabilitation), following the determination of the extent of damages suffered by survivors. ${ }^{192}$

\section{Whither Rape as Genocide?}

Drawing on the 1998 Akayesu Trial Chamber Judgement, which established the link between sexual violence, and more specifically rape and genocide, and mirroring the language of Article II of the Genocide Convention, Article 4 of the ICTY and Article 2 of the ICTR, the ICC regards any acts of sexual violence, including rape actus reus for genocide because they cause serious bodily or mental harm to members of the group. Furthermore, it recognizes that if such acts are committed with the 'intent to destroy, in whole or in part, a national, ethnical, racial or religious group,' then they qualify as genocide. ${ }^{193}$ Specifically, Article 6(b) of the ICC Ele-

189 Koenig, Lincoln and Groth, "The Jurisprudence of Sexual Violence.”

190 Rome Statute, Article 42 (9).

191 For additional structures that have been put into place to assist victims, see Anne-Marie De Brouwer, "What the International Criminal Court Has Achieved and Can Achieve for Victims/Survivors of Sexual Violence," International Review Of Victimology 16.2 (2009), 183-209.

192 Trust Fund for Victims, International Criminal Court International Criminal Court Trust Fund for Victims Website (accessed July 10, 2018).

193 'Sexual Violence and International Criminal Law: An Analysis of the Ad Hoc Tribunal's Jurisprudence \& The International Criminal Court's Elements of Crimes," Women's Initiatives for Gender Justice, September 2005, Http:/Www.I 
ments of Crimes states that the elements for genocide may be considered when:

(a) The perpetrator caused serious bodily or mental harm to one or more persons;

(b) Such person or persons belonged to a particular national, ethnical, racial or religious group;

(c) The perpetrator intended to destroy, in whole or in part, that national, ethnical, racial or religious group, as such;

(d) The conduct took place in the context of a manifest pattern of similar conduct directed against that group or was conduct that could itself effect such destruction. ${ }^{194}$

Second, the Elements of Crimes of the Rome Statute which defines rape as a crime against humanity ${ }^{195}$ may be extended to find rape as the underlying crime of genocide under Article 6 of the Rome Statute, so long as the crime was 'committed with the intent to destroy, in whole or in part, a national, ethnical, racial or religious group.'196 Third, under the Rome Statute, forced pregnancy is defined as 'the unlawful confinement of a woman forcibly made pregnant, with the intent of affecting the ethnic

ccwomen.Org/Publications/Resources/Docs/Overview_Sexual_Violence_And_In ternational_Criminal_Law.Pdf (accessed July 10, 2018).

194 Rome Statute, Article 6 (B).

195 The Elements of Crime of the Rome Statute sets forth the following elements for the recognition of rape as a crime against humanity:

(a) The perpetrator invaded the body of a person by conduct resulting in penetration, however slight, of any part of the body of the victim or of the perpetrator with a sexual organ, or of the anal or genital opening of the victim with any object or any other part of the body;

(b) The invasion was committed by force, or by threat of force or coercion, such as that caused by fear of violence, duress, detention, psychological oppression or abuse of power, against such person or another person, or by taking advantage of a coercive environment, or the invasion was committed against a person incapable of giving genuine consent;

(c) The conduct was committed as part of a widespread or systematic attack directed against a civilian population.

(d) The perpetrator knew that the conduct was part of or intended the conduct to be part of a widespread or systematic attack directed against a civilian population. Article 7 (1) (g)-1Crime Against Humanity of Rape, Elements of Crimes, ICC, 8, https://www.icc-cpi.int/NR/rdonlyres/336923D8-A6AD-40E C-AD7B-45BF9DE73D56/0/ElementsOfCrimesEng.pdf (accessed April 27, 2018).

196 Rome Statute Article 6 (D). 
composition of any population or carrying out other grave violations of international law.' ${ }^{197}$ While there has yet to be a conviction under the ICTY or ICTR for forced pregnancy despite documented evidence of such occurrences in the Bosnian case, theoretically forced pregnancy violates the genocide statute by forcing women 'to carry and often give birth to babies of a different ethnic group [resulting in] severe mental and bodily harm. ${ }^{198}$ In addition, if it can be proved that the intent of the perpetrator met the requirements of the Statute's Article 6, the effects of this suffering on the ethnic group can result in a conviction for forced pregnancy as genocide. ${ }^{199}$

Furthermore, Article 6(d) of the ICC Elements of Crimes recognizes that forced sterilization can be considered an act of genocide when:

(a) The perpetrator imposed certain measures upon one or more persons.

(b) Such person or persons belonged to a particular national, ethnical, racial or religious group.

(c) The perpetrator intended to destroy, in whole or in part, that national, ethnical, racial or religious group, as such.

(d) The measures imposed were intended to prevent births within that group.

(e) The conduct took place in the context of a manifest pattern of similar conduct directed against that group or was conduct that could itself effect such destruction. ${ }^{200}$

In addition, Articles 8(2)(b)(xxii) and 8(2)(e)(vi) of the Rome Statute grant the ICC jurisdiction over rape, sexual slavery, enforced prostitution, forced pregnancy, and enforced sterilization. ${ }^{201}$ Article $8(2)(b)(x x i i)$ also grants the Court jurisdiction over any other form of sexual violence also constituting a grave breach of the Geneva Conventions and article 8(2)(e)(vi) grants the Court jurisdiction over any other form of sexual violence also constituting a serious violation of Common Article $3 .{ }^{202}$

197 Kristen Boon, "Rape and Forced Pregnancy Under the ICC Statute: Human Dignity, Autonomy, and Consent," Columbia Human Rights Law Review 32.4 (2001) (citing "Rape and Forced Pregnancy in War and Conflict Situations: Stark Violations of Women's Reproductive and Sexual Self Determination,” 2 (The Center for Reproductive Law and Policy, 1999)).

198 Short, "Sexual Violence as Genocide," 524.

199 Ibid.

200 Rome Statute Article 6 (D).

201 Rome Statute, Article 8 (2)(b)(xxii) and (e)(vi).

202 Rome Statute, Article 8 (2)(b)(xxii). 
Summarily then, through the codification of the Akayesu Judgement, and building on the jurisprudence of ICTY and the ICTR, the ICC has not only established that rape can be considered an act of genocide, but it has built on the definition of rape developed by the ICTY and the ICTR by recognizing two specific elements: (1)The perpetrator invaded the body of a person by conduct resulting in penetration, however slight, of any part of the body of the victim or the perpetrator with a sexual organ or of the anal or genital opening of the victim with any object or any other part of the body; and (2) The invasion was committed by force, or by the threat of force or coercion, such as that caused by fear of violence, duress, detention, psychological oppression, or abuse of power, against such person or another person, or by taking advantage of a coercive environment or the invasion was committed against a person incapable of giving genuine consent. ${ }^{203}$ This definition is critical in that it includes the elements of force and coercion required in both the Akayesu and Furundzija Judgements, but just as importantly, it acknowledges the reality that individuals who perpetrate such crimes can exploit coercive situations, ${ }^{204}$ cementing recognition that consent cannot be implied in certain coercive circumstances.

Developments such as these in the Rome Statute generated an understanding that the ICC is a far cry from Nuremberg and Tokyo now understood to have delivered only a 'victors' justice' and is in fact the first real 'victims' court' in the international system. Additionally, given the Court's serious attention to gender-based crimes, at first glance expectations surrounding it is understandable. The ICC has for instance, brought charges of sexual slavery and rape as crimes against humanity and as a war crime against Joseph Kony and Vincent Otti, ${ }^{205}$ and 70 charges against Dominic Ongwen of Northern Uganda, 19 of which were related to sex and genderbased crimes, including several counts of rape, sexual slavery, enslavement, forced marriage, torture, outrages upon personal dignity, and forced pregnancy from Northern Uganda. ${ }^{206}$ It also brought charges of sexual slavery and rape as a war crime and crime against humanity against Germain

203 Rome Statute Article 6 (B). It is explained in a footnote that rape can satisfy the elements of the crime of genocide.

204 Ellis, "Breaking The Silence," 240.

205 Situation in Uganda in the Case of The Prosecutor V. Joseph Kony and Vincent Otti, case no.

ICC-02/04-01/05, April 2018, https:/www.icc-cpi.int/uganda/kony/Documents/K onyEtAlEng.pdf (accessed July 10, 2018).

206 Situation in Uganda in the Case of the Prosecutor v. Dominic Ongwen, case no.ICC-02/04-01/15, June 2018 https://www.icc-cpi.int/uganda/ongwen/Docume 
Katanga ${ }^{207}$ and Mathieu Ngudjolo Chui of the Democratic Republic of Congo (DRC), ${ }^{208}$ although Ngudjolo was acquitted in full in 2012, ${ }^{209}$ and Katanga partially acquitted of the sexual violence charges in 2014. ${ }^{210}$ The Court brought charges of acts of rape and outrages upon personal dignity constituting a crime against humanity against Ahmed Harun and Ali Kushayb of Darfur who remain at large. ${ }^{211}$ It also charged DRC's Thomas Lubanga with multiple counts of war crimes including the use of child soldiers $^{212}$ although the case did not include sexual violence charges despite significant witness testimony about the rape of girl soldiers by their commanders. ${ }^{213}$ In March 2016, in a historic landmark case, Jean-Pierre Bemba Gombo of the Central African Republic (CAR) was found guilty of the charges brought against him, making it the first conviction for rape as a war crime and as a crime against humanity by the ICC and the first in terms of finding a commander-in-chief responsible for the behavior of his troops; however he was acquitted in June 2018 on appeal. On June 15, 2017, the Appeals Chamber of the ICC unanimously affirmed the court's

nts/OngwenEng.pdf (accessed July 10, 2018). None of the charges against Ongwen included the systemic use of sexual violence against men and boys committed by the LRA.

207 Situation in the Democratic Republic of the Congo in the Case of The Prosecutor $v$. Germain Katanga, case no. ICC-01/04-01/07, March 2018, https:/www.icc-cpi.int/ $\mathrm{drc/katanga/Documents/KatangaEng.pdf} \mathrm{(accessed} \mathrm{July} \mathrm{10,} \mathrm{2018).}$

208 Situation in the Democratic Republic of the Congo in the Case of the Prosecutor $v$. Mathieu Ngudjolo Chui, case no. ICC-01/04-02/12, February 2015, https://www.ic c-cpi.int/drc/ngudjolo/Documents/ChuiEng.pdf (accessed July 10, 2018).

209 "ICC released Mathieu Ngudjolo Chui From Custody Following His Acquittal," ICC Press Release, December 21, 2012, https://www.icc-cpi.int/Pages/item.aspx? name $=$ pr868 (accessed July 10, 2018).

210 "ICC Partially Convicts Katanga In Third Trial Judgment, Acquitting Katanga of Rape and Sexual Slavery," International Justice Monitor, May 16, 2014, https://ww w.ijmonitor.org/2014/05/icc-partially-convicts-katanga-in-third-trial-judgment-ac quitting-katanga-of-rape-and-sexual-slavery/ (accessed July 10, 2018).

211 The Prosecutor v. Ahmad Muhammad Harun ("Ahmad Harun") and Ali Muhammad Ali Abd-Al-Rahman ("Ali Kushayb"), case no. ICC-02/05-01/07, April 27, 2007, https:/www.icc-cpi.int/darfur/harunkushayb (accessed July 10, 2018).

212 Situation in the Democratic Republic of the Congo in the Case of The Prosecutor $v$. Thomas Lubanga Dyilo, case no. ICC-01/04-01/06, November 2017, https:/www.i cc-cpi.int/drc/lubanga/Documents/lubangaEng.pdf (accessed July 10, 2018).

213 Lisa Gambone, "Failure to Charge: The ICC, Lubanga \& Sexual Violence Crimes in the DRC," Foreign Policy Association, July 22, 2009, https://foreignpolic yblogs.com/2009/07/22/failure-to-charge-the-icc-lubanga-sexual-violence-crimes-i n-the-drc/ (accessed July 10, 2018). 
power to bring charges against Bosco Ntaganda for war crimes of rape and sexual slavery committed against child soldiers in the DRC. ${ }^{214}$

The significance of each of these cases aside, the ICC has thus far indicted only one person for genocidal rape-all others, as noted, were indicted for rape as a war crime or as a crime against humanity. In a landmark move in 2010, Prosecutor Moreno Campo, based on the fact that the first indictment of Omar Hassan Ahmad al-Bashir in 2008 could not include the allegation of the orchestrated rapes of thousands of civilian women, primarily of the Fur, Masalit and Zaghawa ethnic groups in the Darfur region of Sudan amended the arrest warrant to include the crime of genocide. $^{215}$ In so doing, al-Bashir's case became the first time the ICC has charged an individual for the use of rape as an instrument of genocide. ${ }^{216}$ Since the issuance of his warrant however, al-Bashir remains at large.

The glaring absence of charges of genocidal rape in the ICC's dockets should give us pause. It demonstrates what Powell has described to be a 'legal fragility'217 that continues to obstruct an effort in trying to connect rape to genocide, even though as outlined earlier, the deliberate infliction of psychological harm, the intentional transmission of STDs, forced impregnation as specific strategies to destroy a particular group in whole or in part ( as was in the case of the Tutsis in Rwanda or the Bosnian Muslims in former Yugoslavia) could be very well considered as acts of genocide. However, beyond specific cases tried in the ICTY and the ICTR the fact that such grounds have not been pursued underscore that such premises remain largely theoretical and are not firmly established within ICL. Subsequently, even today identifying rape as a crime of genocide not only remains controversial but is also legally tenuous, and reflects the reluctance of the ICC to bring these cases for sentencing.

Several explanations have been offered regarding the ongoing pattern in the international legal system of why wartime rape and sexual violence were not investigated and prosecuted since Nuremberg and Tokyo, and why potential cases of such violence as acts of genocide were not adjudicated sufficiently in the ICTY and ICTR, and certainly not since the ICC has

214 Situation in the Democratic Republic of the Congo in the Case of the Prosecutor V. Bosco Ntaganda, case no. ICC-01/04-02/06 OA5, https://www.icc-cpi.int/CourtRec ords/CR2017_03920.PDF (accessed July 10, 2018).

215 Prosecutor v. Al Bashir, case no. ICC-02/05-01/09, Second Warrant of Arrest (July 12, 2010), https://www.icc-cpi.int/CourtRecords/CR2010_04825.PDF (accessed July 10, 2018).

216 Ibid.

217 Powell, "You Have No God," 42. 
come into existence. First, the inadmissibility of gender-based sex crimes since the time of Nuremberg and beyond have been based on the assumption that such violations are by-products of war and not state-level crimes that could be prosecuted. Irrefutably, in Nuremberg and Tokyo, the lack of evidence, the will to collect and corroborate them, the absence of a support structure for witnesses and survivors, in conjunction with explicit and implicit biases in law and amongst lawyers have played a critical part in their invisibility. Even in the 1990s, misperceptions surrounding such violations ensured that initially in particular, crimes against women and girls were largely neglected in the ICTY and ICTR. By and large, prosecutors have been reluctant to take on cases of rape and sexual violence because of the challenges involving witness testimony. In the case of ICTY for instance, there was a common assumption that rape cases were too time consuming and complicated, ${ }^{218}$ and that rape survivors were too emotional and incoherent on the stand. ${ }^{219}$ In the case of Tokyo, several documented cases of violations against women and girls, including the realities of the 'comfort women' were not brought before the courts.

Second, the consistent gender gap in the composition of international and local tribunals have historically meant that gender-based crimes and sex crimes have had very low prosecution rates. In the Nuremberg trials, there were only 33 witnesses called for the prosecution and 61 for the defendants against all 24 first-tier defendants. ${ }^{220}$ Women did not feature as witnesses in either of the trials. Although there is an absence of data on the gender composition of the ICTY, the ICTR and the ICC in their entirety, the percentage of female judges in the ICTY until 2004 was never higher than 24 percent; sometimes it was even as low as 12.5 percent. ${ }^{221}$ In the case of the ICTR, only 24 per cent of judges generally were female although at times, it did climb to 40 per cent. ${ }^{222}$ In both the ICTY and the ICTR, the role of female judges in pushing for the prosecution of such crimes is notable. For instance, Justice Odio Benito in the ICTY called upon the Prosecution to review its indictment to add gender crimes, either as

218 Sara Sharrat, Gender, Shame and Sexual Violence: The Voices of Witnesses and Court Members at War Crimes Tribunals (New York, NY: Routledge, 2011), 63.

219 Ibid., 56.

220 Telford Taylor, The Anatomy of The Nuremberg Trials: A Personal Memoir (New York, NY: Skyhorse Publishing, 2013).

221 Sharrat, Gender, Shame and Sexual Violence, 19.

222 Ibid. 
a crime against humanity or as a grave breach or war crime. ${ }^{223}$ Additionally, in the Akayesu case, Justice Pillay played a critical role in eliciting evidence from witnesses on sexual and gender-based crimes and was instrumental in the Prosecution's amendment of the indictment to include crimes of sexual violence. ${ }^{224}$

Third, as was both illustrated in the case of both ICTY and ICTR, the gender of the Prosecutor may also impact which crimes are brought and how certain acts are defined. Powell notes that 'the lack of an equitable gender balance on the ICTY and the ICTR may explain why genocidal rape was so haphazardly prosecuted and why the definition of rape became narrower over time.'225 The lessons learned regarding the impact of gender in the constitution of the court and its impact on cases has had notable influence on the ICC-since 2015, all the leading positions of the court including the Presidency, two Vice Presidencies and the office of the Chief Prosecutor have been occupied by women. While these elections are extremely new appointments and it may still be too early to study their impact in the indictment and prosecution of cases of rape and sexual violence, such developments are further strengthened with current ICC rules of procedure, which allow special protections for witnesses and survivors of sexual violence including (1) being able to testify in closed hearings; (2) the ability to have a psychologist or family member present while testifying; (3) protecting the confidentiality of victim testimony; and (4) limited definition of "consent" and corroboration is not needed to prove crimes of sexual violence. ${ }^{226}$ Despite these measures, insensitivity of defense counsel, ongoing misunderstandings about rape and sexual violence, the stigma and social ostracization attached to such crimes in many cultures has meant that prosecutors are seriously impeded in their effort to collect sufficient evidence and eyewitness and survivor testimony to prosecute such cases.

Finally, the realities outlined above compound the already insurmountable challenge that exists to meet the evidentiary standards for prosecuting genocidal rape in international criminal law. After all, genocidal rape contains an added layer of complexity - not only does the prosecution have to prove that rape and sexual violence has been committed as a strategy of war, but that such acts were harnessed with the explicit purpose of destroying

223 Richard J. Goldstone, "Prosecuting Rape as a War Crime," Case Western Reserve Journal of International Law 34.3 (2002), 277-285.

224 Ibid.

225 Powell, "You Have No God," 43.

226 See generally ICC Rules of Procedure and Evidence, supra note 183. 
a particular ethnic, political or religious group in whole or in part. Correspondingly, the Prosecution has to prove that rapes were committed, but also establish the motivation for such a crime to prove it was an act of genocide. The challenges of proving intentionality with the purported outcome in conjunction with the complexities of prosecuting gender-based sexual violence continue to plague the ICC. Short succinctly notes that instead of being intimidated by such challenges, 'the prosecutors should include as many counts and theories as possible in order to test the boundaries of the practical law in determining how sexual violence should be legally understood. The real problem with terms such as genocidal rape, is that with their use we tend to condense instead of expand the possibilities for prosecution. ${ }^{227}$ The legal deliberations surrounding the plight of contemporary tragedies, such as that of the Yazidis and the Rohingyas will irrevocably rely on this kind of creative strategy.

\section{Building on the Legacy: Rape as Genocide, the ICC and Beyond}

Almost 70 years ago, the Nuremberg and Tokyo trials broke new ground in the first ever attempt by the international system to address the question of individual criminal culpability in the context of war. However, the focus of both the trials was the prosecution of those who launched an aggressive war, and not on violations such as rape and sexual violence. While Nuremberg's Charter itself did not explicitly mention any form of sexual violence, its trial records did contain extensive evidence of sexual violence, and one could argue sex-related crimes were included as evidence of the atrocities prosecuted. Furthermore, Nuremberg implicitly recognized sexual violence as torture, and its Article 6 (c) and more specifically Control Council Law No. 10 played critical roles in recognizing rape and sexual violence as war crimes. Third, it was Nuremberg where the term 'crimes against humanity' was coined, bringing war crimes under a different light in international law, and under the scope of human rights. In a similar vein, while the Tokyo trials did not single out and extensively prosecute the use of rape and sexual violence in wartime, it acknowledged their instrumentalization as violations of existing IHL.

Given that the concept of genocide had not emerged in legal scholarship at the time of Nuremberg and Tokyo, it is impossible to draw a straight line between the contributions of these trials and their legacy in

227 Short, "Sexual Violence as Genocide," 505. 
terms of what constitutes genocidal rape in legal theory. However, it is undeniable that their official recognition of rape and sexual violence as violations of IHL and their contributions to ICL paved the way for the ad hoc tribunals of the 1990s. Furthermore, the lessons learned from Nuremberg and Tokyo, particularly in terms of the need to bring in witness testimony and prosecute individuals for gender- based sex-crimes as violations of IHL and ICL, created the imperative groundwork for an international court to create legal precedence. It is the contributions of ICTY and ICTR, dovetailing with the tireless efforts of feminist scholars and activists, at a time of shifting of international norms, that made it possible to challenge the gender composition of the tribunals, investigate and prosecute rape and sexual violence, create case law, which expanded the definition of such crimes in legal jurisprudence, and even try such egregious violations as acts of genocide under the Genocide Convention.

Existing legal theories of what constitutes genocidal rape in the Rome Statute would not have been possible without the ground-breaking cases of the 1990s. Certainly, recognition of rape and sexual violence as torture, or their strategic use against men and boys owes much to the deliberations of ICTY and ICTR, as ICC itself continues to strive toward creating legal precedence as in the case identifying forced marriages or the use of child soldiers during conflict as war crimes and crimes against humanity. Nevertheless, the shadow of Nuremberg and Tokyo in terms of issues related to gender still linger, particularly when it comes to trying cases where a link could be made between genocide, rape and sexual violence.

This chapter has outlined specific reasons as to why genocidal rape continues to largely evade the ICC and acknowledges that the standard for establishing the intentionality to destroy a particularly group in whole or in part is exceptionally high. Logistical and sociological challenges relating to the identification of witnesses, corroborating testimony and finding survivors willing to testify on a violation immersed in social stigma is challenging. Yet, legal precedence has been established by the ICTY and the ICTR in cases where sexual torture, forced impregnation, forced displacement and forced transmission of STDs using rape and sexual violence has taken place during conflict. The body of legal literature now recognizes a significant number of ways rape and sexual violence can be instrumentalized to commit genocide. The notable absence of genocidal rape cases in the ICC docket is therefore all the more striking. As new conflicts arise in the international system where there is evidence of the commission of genocide, and widespread rape and sexual violence is used systematically, there is greater urgency than ever before for the ICC to push beyond its reluctance and examine incidents for potential cases of genocide. Similarly, 
hybrid and national courts that have emerged in Kenya, Uganda, Cambodia, as well as the ones of the future need to pay serious attention to existing ICL, IHL, jus cogens and the Rome Statute to seriously examine how rape and sexual violence may not only constitute war crimes and crimes against humanity, but in some instances, as acts of genocide. Failure to do so will not only bring to question the potency of the ICC and other institutions of legal jurisprudence, underscore the ongoing concerns about the failure of international law to take into account questions of gender in times of conflict but in the end, result in them reflecting some of the shortcomings of Nuremberg and Tokyo. 


\section{The Documentary Record of Nuremberg in the Twenty-First Century}

Judith Haran

"This is the raw material of history in wonderful profusion." -Telford Taylor

Few historians would argue that the Nuremberg Trials constitute one of the most significant events of the twentieth century. The trials set the stage for the development of the modern law of warfare, the codification of protocols in the fields of human rights and medical experimentation, and perhaps most importantly, created an indelible, if at times incomplete, record of the crimes of Nazi Germany. In Quincy Wright's summation of the trials' raison d'être in the Harvard Law Review, the third point is of particular interest in this regard:

The Nuremberg trials were designed (1) to carry out the Allied war aim of punishing the major war criminals without denying due process of law to the accused, (2) to influence opinion in Germany and elsewhere in order to deter future aggressions and atrocities, (3) to contribute to the historical record and to public enlightenment by making available authentic evidence of the process of development and methods of the "Nazi Conspiracy," and (4) to contribute to the development of international law, especially on the subjects of war, aggression, and atrocities. ${ }^{1}$

Former Harvard Law School librarian Terry Martin, an early organizer of the Nuremberg Trials Project at Harvard, added this related point: "The documentation from such tribunals helps establish a permanent record of the truth that makes it more difficult for revisionists to try to alter history." ${ }^{2}$ The seventy-fifth anniversary (in 2020) of the trials' commencement offers a welcome opportunity to examine the current status of the evidence.

1 Quincy Wright, "Nuremberg: German Views of the War Trials (review)," Harvard Law Review 69.5 (1956), 964-972, 964, DOI: 10.2307/1337586.

2 "HLS Launches Nuremberg Trials Project," Harvard Law Today, July 31, 2003, https://today.law.harvard.edu/hls-launches-nuremberg-trials-project/. 
The trials were unusual, even precedent setting, in many ways. One of these was the fact that a full three-quarters of the evidence presented was documentary. (An early member of the IMT prosecution staff, Colonel Bill Donovan of the OSS, was said to have departed over this very issue, as he preferred trials based on witness testimony.) ${ }^{3}$

When we think about Nuremberg documents, we tend to think of the familiar Blue, Red and Green Series, the sixty-seven volumes published by the American government around the time of the trials' end. These volumes make up an impressive collection: they take up ten feet of shelf space and weigh some 150 pounds. Despite their size, they contain only a small percentage of the trial records (the Blue Series, Trial of the Major War Criminals Before the International Military Tribunal, reproduces the transcript of the IMT trial, as well as prosecution evidence in original German; the Red Series, Nazi Conspiracy and Aggression, offers 8 volumes of this evidence translated into English; the fifteen-volume Green Series, Trial of War Criminals Before the Nuremberg Military Tribunals under Control Council Law No. 10 , offers excerpts of the daily transcripts from the twelve subsequent trials, and selections from the evidence). Robert Kempner, Deputy Chief Counsel of the US prosecution team, stated that the volumes contain less than $10 \%$ of the trial-related documentation. ${ }^{4}$ During the following decade, attention turned to more pressing topics, such as the Cold War, and no further publication of Nuremberg documents was attempted. Fifty years would go by before this situation began to change.

Given the universally acknowledged importance of the thirteen Nuremberg trials, it is surprising how little has been written about their documentary record. A review of the evidence suggests one likely reason: the story of their origin is a confusing one, and the story of where they ended up is only marginally less so.

3 Telford Taylor, "The Use of Captured German and Related Records in the Nuernberg War Crimes Trials," Captured German and Related Records, a National Archives Conference, ed. Robert Wolfe (Athens: Ohio University Press, 1974), 96. This volume is the classic work on the larger topic of captured German records in the United States.

4 Robert Kempner, "The Nuremberg Trials as Sources of Recent German Political and Historical Materials," American Political Science Review 44.2 (1950), 447-459, 449 . 
Origins: From Chaos to Order ... more or less

Nuremberg documents are divided into two groups: those generated before and during the war, mostly by the Nazi regime, and captured by Allied troops in 1944-1945, and those generated after the war (interrogation records, affidavits, and records of the court, including transcripts, briefs, motions, etc.) The bulk of the prosecution evidence came from the first group, the files captured at the end of the war.

Captain Lester Born, an archivist working for the Army in 1945, described the chaotic situation of the summer of 1945 in his paper on the Ministerial Collecting Center at Kassel. ${ }^{5}$ (The following description is based on this paper.) During the final year of the war, as Allied troops moved from the periphery of the Reich closer to its center, specialized teams searched for and found many caches of documents in unlikely places, including castles, mines, sawmills, and caves. The records were often in complete disorder, with pages damaged or destroyed by water or fire. (From 1943 onward, German ministries had moved, attempted to destroy, or abandoned huge quantities of records. Orders went out from the top to destroy everything, but most of the caretakers of the files, who had spent years carefully curating them, resisted these orders.) US and British forces set up document collecting centers throughout Germany, and enormous quantities of material began to pour in immediately.

The document center at Kassel was only open for half a year, but within the first three months, the hastily repaired complex of buildings became home to some 1200 tons of documents and 52 tons of microfilm. This was a true bootstrap operation. The officers in charge had to clear out and repair buildings, get rid of significant quantities of explosives and hazardous chemicals, and even reopen a local sawmill to provide shelving, so that the contents of all those boxes would be accessible.

Accessibility was high on the agenda, because so many people needed these files. There was no functioning government left in Germany in the summer of 1945, no remnant of intact bureaucracy that the Allies could administer. It all had to be recreated. Many of the visitors to the document centers were seeking records that would help them in this gargantuan task. The staff of this one document center alone contained hundreds of Germans who had been employed in various Nazi ministries. They provided invaluable assistance in sorting, cataloguing, and classifying the avalanche

5 Lester Born, "The Ministerial Collecting Center near Kassel, Germany," American Archivist 13.3 (1950), 237-258. 
of paper, as well as preparing thousands of cataloguing cards, accession lists, and the critical lists of what had been received, shipped, and reproduced. In addition to hauling heavy crates from trucks into buildings, they made photostats of whatever was requested by visitors, and once even spread index cards out to dry on the grass after a flood. Born notes that almost all of the shipments arrived unannounced; one day a 70,000 volume library from the Foreign Office turned up, in complete disarray; another day saw the arrival of the complete files of the Polish Weather Bureau.

The operation at Kassel was only a small part of the whole. Documents related to industry (business and correspondence records of the Farben, Flick, and Krupp industrial empires) were collected at Fechenheim, outside of Frankfurt. Naval documents, including most of the history of the German navy, ended up in Tambach castle, fifty miles north of Nuremberg, far from the sea. Thousands more tons of German documents found their way to the Berlin Document Center. Records of the German High Command, Party records, and more were packed into crates and footlockers for the long journey across the Atlantic to the Pentagon. And even now we still do not know how much of the record of the Third Reich was taken by the Soviets. For when it came to documents (and other treasures, such as gold, currency and artwork) there was no Four-Power agreement. Whoever got there first took whatever they found.

Visitors to the document centers included officials from countries that had been occupied by Germany, members of various military and intelligence staffs, as well as the many officials of OMGUS, the Office of Military Government, United States, that had been charged with no less a task than administering civil society after cessation of hostilities. Prosecution staff from Nuremberg also made up a significant percentage of the visitors. Day after day they sifted through the chaotic assemblage of files, looking for evidence of war crimes and crimes against humanity. Fortunately, such evidence was not hard to find; the Nazi regime had kept meticulous records of everything. Among their finds was the sole surviving copy of the Wannsee Protocol and the only known surviving set of official reports on the activities of the Einsatzgruppen in the Soviet Union (these reports, about the activity of the SS execution squads in the Soviet Union, was to form the basis of the ninth of the Subsequent Trials, the Einsatzgruppen Trial).

At the beginning, control over the captured documents was incomplete. Many original documents disappeared and were never seen again. Eventually, administrators insisted that investigators from Nuremberg take only photostats, not originals. Even so, many of these documents had been 
ripped out of their original contexts, sometimes literally, creating a nightmare for post-1949 archivists and historians.

Investigators didn't limit themselves to these document centers, however. Scouting teams from Nuremberg went on missions as far afield as Poland, Czechoslovakia, Holland, even Norway. The library at headquarters of I.G. Farben was a rich source of material. OCCWC (Office of Chief of Counsel for War Crimes) had offices in Berlin, Frankfurt, Paris, and Washington, with analysts (and shipping teams) in all of these. With documents coming in from all of these sources, those left behind at the Palace of Justice had to scramble to make arrangements for housing all of this paper.

\section{From Documents to Convictions}

Several authors have referred to the Document Room at Nuremberg as the most important location after the courtrooms themselves, or even as the "hub of the trial." Shelves filled the room from floor to ceiling, necessitating the frequent use of ladders. John Mendelsohn, author of Trial by Document, found so few records about the document operation that he had to rely on interviews to understand how it worked. Many more documents arrived than were eventually used. Faced with stacks of collected material, and with more arriving hourly, lawyers and analysts had to choose those items with the greatest promise of incriminating the defendants.

The man in charge of the Document Division for the IMT, Major William H. Coogan, certified authenticity for whatever the prosecution presented in court. For the later Nuremberg Military Tribunal (NMT, in charge of the subsequent trials), his counterpart was civilian Fred Niebergall, Chief of the Document Control Branch, OCCWC. Niebergall was responsible for safeguarding, duplicating, and arranging for translation of everything. The Language Division, in its peak year of operation (19471948), translated and stenciled 133,762 pages. $^{6}$

After selection, the next step was classification. Document Room staff sorted many documents by general subject (i.e. "NG for Nazi Government"), but a significant number of items, especially for the IMT, were

6 John Mendelsohn, Trial by Document: The Use of Seized Records in the U.S. Proceedings at Nuernberg (Ann Arbor, Michigan: University Microfilms, 1975), 26. (Considered to be an essential reference for anyone dealing with the documentary record of Nuremberg.). 


\section{Judith Haran}

sorted by provenance/source. Ten series were established for the IMT; the subsequent trials generated six more. A list of major groups follows:

IMT series:

C Crimes

D Industry

EC Economics

ECH Economics-Heidelberg

ECR Economics-Reichskreditkassen

L London

M Melvin (Melvin Jones, Assistant Prosecutor, UK)

PS Paris-Storey (Col. Storey, the principal document collector for IMT)

$\mathrm{R} \quad$ Rothschild (Lt. Rothschild in London)

TC Treaty Committee

NMT series:

NOKW Nuremberg High Command (Oberkommando der Wehrmacht)

NO Nuremberg Organizations

NI Nuremberg Industrialist (includes subseries NID and NIK)

NG Nuremberg government (ministries)

NM Nuremberg miscellaneous (mostly labor related)

NP Nazi Party abroad (Auslandsorganisation)

After documents had been given a series identity/prefix, ten photostat copies were made, a stencil was cut, and 100 mimeographed copies were produced. After this came translation (into English, French, and Russian for the IMT, but subsequently only into English and German for the NMT trials) and then description. This occurred via two methods: register cards and Staff Evidence Analyses (SEAs). Register cards included basics such as title, date, provenance, language, original document ID, Nuremberg document number, persons/organizations implicated; the SEAs also included a summary, an explanatory note, and a list of subject headings. Usefulness of the SEAs varied widely according to the ability of the analyst to comprehend the subject matter (and to read German accurately). Analysis, far from being a leisurely pursuit, was performed under a lot of time pressure. 
After analysis, documents went through final selection by prosecution teams and were assembled into "document books" by topic. Most books had a comprehensive index at the beginning, sometimes running to several pages. Many documents, referred to as "loose documents," never made it into these books; this was particularly true of items introduced during cross-examinations. A lot of potential evidence wasn't chosen for the document books to start with, and not everything in those books was presented or accepted as evidence in the court room.

Although figures vary by source, noted archivist Fritz Epstein stated that for all of the trials, a total of over 750,000 mimeographed pages were produced. ${ }^{7}$ This included a total of 330,000 pages of transcripts alone, of which only the IMT transcript was published.

\section{Finding Homes for 100 Tons of Records}

On April 13, 1949, the Ministries Trial, the last and longest of the judicial proceedings, reached an end. The Publications Team had been hard at work for some time already, deciding which documents and trial excerpts to include in the forthcoming government volumes. Now it was time for the vast, complicated machinery, set up nearly four years before, to be taken apart. The written record of the trials had to be addressed with an eye to the future. The immense task of dealing with the residual documents (over one hundred tons, according to John Mendelsohn) ${ }^{8}$ fell to the Chief of the Document Division, Fred Niebergall.

In his Final Report to the Secretary of the Army on the Nuernberg War Crimes Trials, Taylor, the Chief of Counsel for the twelve subsequent Nuremberg trials, describes the process. He makes it clear that "one of the most important problems connected with the deactivation of the military tribunals was the disposition of the very large amount of documents ... assembled in connection with the trials." After noting that the complete original record was to be deposited at the National Archives, he goes on to

7 Fritz Epstein, "Washington Research Opportunities in the Period of World War II," American Archivist 17.3 (1954), 225-236, 235.

8 Mendelsohn, Trial by Document, 128.

9 Telford Taylor. "Final Report to the Secretary of the Army on the Nuernberg War Crimes Trials under Control Council Law No. 10,” Washington, DC: U.S. Government Printing Office, 1949, 98, https://www.loc.gov/rr/frd/Military_Law/pdf/NT_fi nal-report.pdf. 
list the repositories to which a "fairly complet" set of records was being donated:

- Library of Congress

- Harvard Law School Library

- Nuernberg State Archives (while the trials were still in progress, a representative of this archive had been hard at work on site, securing documents)

- One set donated to each of the nations that maintained a permanent delegation at Nuremberg: England, France, Holland, Czechoslovakia, and Poland (USSR is not mentioned in this list)

Taylor then goes on to list the destinations of the less complete sets (consisting of court transcripts, prosecution documents, and staff evidence analyses only):

- University of California

- University of Chicago

- Columbia Law School

- Duke University

- Hoover Institute (Stanford University)

- New York Public Library

- University of North Dakota

- Northwestern University

- Princeton

- University of Michigan

- University of Washington Law School

- U.S. Military Academy at West Point

- University of Washington

- Wiener Library, London

- United Nations at Lake Success, NY (temporary headquarters until 1952)

The following German universities were also listed as recipients of trial records: Bonn, Heidelberg, Frankfurt, Goettingen; other sets were donated to the Bayerische Staatskanzlei in Munich, the Swiss Social Archives in Zurich, Yad Vashem, and Berlin's Kaiser Wilhelm Institute (current status of non-US collections has not been investigated).

Later sources, including an official OMGUS press release, named additional US repositories as recipients of these records. Four such lists exist, and none of them agree. Together, these lists name twenty-eight US libraries and/or archives. Nearly seven decades later, only twelve of these institutions were able to confirm the existence of trial records in their collec- 
tions. Appendix A provides a list of these, with current status of records (reported or discovered as of 2018).

Since the records' arrival in the US, very little has been written about the documents themselves (as opposed to the content of the documents). Only four articles on this topic have ever been published in English: two by members of the prosecution team, one by the head of the Document Division, and one by a Library of Congress archivist-all prior to 1955. Chief of Counsel Telford Taylor wrote about research possibilities afforded by the trial record ${ }^{10}$ before the final trial had concluded; a year later Deputy Chief of Counsel Robert Kempner summed up the situation in The American Political Science Review. ${ }^{11}$ Fred Niebergall, head of the Document Division, described the records' current status for the Law Library Journal. ${ }^{12} \mathrm{~A}$ few years later, Library of Congress archivist Fritz Epstein wrote about "research opportunities in Washington, DC for the WWII period."13

The situation is not much different with regard to books. Of the three relevant titles that appeared by the mid-seventies, two were written by NARA archivist John Mendelsohn: his $\mathrm{PhD}$ thesis ${ }^{14}$ analyzing the four main document series used in the twelve "subsequent" Nuremberg Military Tribunal trials, still considered a primary source for anyone dealing with these documents, and his detailed finding aid to the microfilmed NARA documentary record for NMT Case 9, the "Einsatzgruppen Trial." 15 In 1976, Jacob Robinson, a legal scholar, and Henry Sachs, a former document analyst at Nuremberg, compiled a detailed, well-indexed list of 3001 Nuremberg documents (listed by evidence file number, and heavily annotated) pertinent to the Holocaust. ${ }^{16}$ One other useful catalogue is the 1961

10 Telford Taylor, "Forum Juridicum: An Outline of the Research and Publication Possibilities of the War Crimes Trials," Louisiana Law Review 9.4 (1949), 496-508, available at: http://digitalcommons.law.lsu.edu/lalrev/vol9/iss4/4.

11 Kempner, "The Nuremberg Trials."

12 Fred Niebergall, "Brief Survey Concerning the Records of the War Crime Trials Held in Nurnberg, Germany,” Law Library Journal 42 (1949), 87-90.

13 Epstein, "Washington Research Opportunities."

14 Mendelsohn, Trial by Document.

15 John Mendelsohn, War Crimes Trials: Records of Case 9 (Washington, DC: National Archives and Records Administration, 1978).

16 Jacob Robinson and Henry Sachs, The Holocaust: The Nuremberg Evidence, Part One (Jerusalem, Israel: Yad Vashem, 1976). (An extremely useful, exhaustive compendium of evidence relating to the Holocaust: 3001 documents are described, and each listing notes whether the document has appeared in other publications. 
Catalogue of Nuremberg Documents ${ }^{17}$ from London's Wiener Library, which not only lists prosecution and defense documents, but also references a separate list of 4500 interrogation summaries. An additional catalogue of Nuremberg-related materials is the useful European War Crimes Trials: a Bibliography, ${ }^{18}$ published by the Carnegie Endowment for International Peace. This well-annotated list of books and articles is unfortunately limited by its temporal coverage (1941-1950) as well as a lack of later editions.

The most recent discussion of the documentary record is another essay by Telford Taylor, "The Use of Captured German and Related Records in the Nuernberg War Crimes Trials," 19 found in the classic 1974 anthology, Captured German and Related Records, a National Archives Conference. Although the trial record has contributed to countless works of historical and legal analysis since 1949, no further works in English discussing the documents themselves have emerged. ${ }^{20}$

After all this time, some might argue that this lack of discourse on the trial documents no longer matters. Access to trial records remains a challenge; fewer than half of the record sets described in 1949 can now be located. Apart from the complete trial record held at NARA, a significant set of Nuremberg trial records can be found at only a handful of the listed institutions. ${ }^{21}$ Telford Taylor's statement that "the most immediate problem

Names, places, subjects, institutions, and areas are indexed (index is half of the book).).

17 Wiener Library, Catalogue of Nuremberg Documents (London, Wiener Library, 1961). (Mimeographed list of their holdings, organized into prosecution documents, defense documents, and a sixty-page list of testimonies with relevant trial transcript pages noted.).

18 Inge Neumann, European War Crimes Trials: A Bibliography (New York: Carnegie Endowment for International Peace, 1951). (Intended for scholarly use in the field of international law, this detailed bibliography includes publications in several languages between 1941 and 1950. Roughly 2/3 of the citations are annotated.).

19 Taylor, "Captured Records."

20 An amusing exception to this was the flurry of news articles, mostly from 2013, on the controversy between the US Holocaust Memorial Museum and the heirs of Deputy Chief of Counsel Robert Kempner, who had shipped eight tons of documents from Nuremberg to his home in Pennsylvania in 1949 (see Robert Wittman and David Kinney, The Devil's Diary: Alfred Rosenberg and the Stolen Secrets of the Third Reich (New York: Harper, 2016).

21 See Appendix A for complete list. Note also that many repositories in addition to those named have collections of personal papers of trial participants: Cornell's 
is that those records be disposed of in such a way that they will be available to those who need them,"22 remains as true today as it was in 1949.

\section{Uses of the Trials' Record}

Various authors have described how these records have been used over the years, beyond the most obvious application-historical research. Mendelsohn states that prosecutors in Germany used them to convict many war criminals after 1950.23 In West Germany alone, more than 70,000 people were tried for war crimes by the end of 1968 , with over 6,000 convictions. By 1965, 13,000 people had been convicted of war crimes in East Germany, including personnel of Sachsenhausen concentration camp. The records were frequently consulted during the writing of memoirs by judges (Musmanno), defense attorneys (Kranzbuehler, Haensel), prosecution attorneys (Taylor, Harris, Kempner), defendants (von Knieriem, Speer) and even translators (Sonnenfeldt). Telford Taylor is not the only writer to issue a caution about the use of these records, pointing out that documents were selected for the purposes of proving the guilt of German defendants, not with an eye towards the historical record. In addition to content concerns, not-infrequent errors in translation continue to cause headaches for researchers, just as they did for defense counsel during the trials.

One less obvious use of evidence files was in the search for missing persons after the war. Several affiants in Trial 8, for example, testified to the kidnapping of children in the East, often giving names. Documents captured from the files of Lebensborn and the Volksdeutsche Mittelstelle frequently contain long lists of names of adults and children living in resettlement camps after being expelled from their native land.

\section{Trial Records in the Modern Era: The Case of Harvard Law School}

Apart from the National Archives, Harvard is the only US institution currently thought to have a nearly complete set of trial records. In 1949, they received approximately one million pages (i.e., between seven and twelve

Donovan collection and the Robert Jackson papers at the Library of Congress are only two examples. See Appendix B for list of these.

22 Taylor, "Forum Juridicum," 508, emphasis added.

23 Mendelsohn, Trial by Document, 163-164. 
tons of paper). In the 1990s, Law School librarians realized that this enormous, aging collection would need significant attention to ensure its survival for use by future researchers.

Over the first fifty years of their existence, the trial records had been stored haphazardly wherever space could be found: unused stairwells, filing cabinets in damp cellars. Some boxes sustained water damage as a result. Preservation of the collection became ever more urgent due to the fragile condition of the paper. Library staff opted for digital preservation, with the eventual goal of access to the entire record of the trials in English via a permanent website.

The HLS collection contains transcripts for each of the trials, including indictments, arraignments, opening and closing statements, judgments, and sentencing, as well as trial briefs, all prosecution and defense exhibits (referred to as case files); plus the much larger set of source documents from which most prosecution trial exhibits were selected. These so-called "evidence files," a full sixty percent of the HLS collection, contain not only captured Nazi documents, but also affidavits, interrogations, articles from newspapers, and excerpts from Nazi law journals.

750,000 pages from the collection were selected for digitization, an enormous undertaking that would end up taking far more time and resources than anticipated. (The remaining 250,000 pages were duplicates, or were in German.) As digitization progressed, the paper originals were transferred to the Harvard Depository, an enormous high-density book and media storage facility located in a remote forest in Southborough, MA, thirty miles west of the Law School.

\section{The Collection: Making All of this Paper Accessible}

Before the arrival of the Internet, a collection as large and unwieldy as the million-plus pages of Harvard's Nuremberg records presented library and archive staff with a serious question: how to arrange these papers and make them fully accessible to users? The fact that so few of the US repositories owning these records (other than NARA) appear to have created a finding aid in the fifty years since their original distribution speaks to this challenge. ${ }^{24}$

24 NARA archivists compiled three finding aids between 1949 and 1966. The first one, Preliminary Inventory No. 21, was digitized by Google and put online by HathiTrust. Aside from the official, published records of the Trials contained in 
Harvard Library staff decided early on that this challenge required a new tool, something far deeper and richer than a traditional $20^{\text {th }}$ century finding aid. The ambitious objective of full-text and document-level discovery mandated the use of a website, supported by a sophisticated database capable of holding all data fields relevant to users. The website's user interface also features rich orientation materials:

- for each trial:

- a basic narrative

- an indictment, with specific counts

- list of trial issues (e.g., hostage taking, medical experiments)

- a detailed chronology, with dates matched to transcript pages

- lists of defendants, counsel for both sides, judges, witnesses

- explanatory material (charts, list of evidence file groups, etc)

- a "Who Was Who" in Nazi Germany

- an explanation of how trial documents are organized, structured, and analyzed

- a choice of basic or advanced fielded search for documents (for NMT trials 1-4 and 7 so far) and document images

- keyword search for trial transcripts (for NMT trials 1-4 and 7 so far)

- a collection of trial-related photographs

- a history and description of the project

As of this writing, the Nuremberg Trials Project website has 55,285 pages analyzed, uploaded and ready for inspection. These include the trial-related "case files" for Cases 1-4 and 7, plus "evidence files" - other documents relevant to Cases 1 and 2, and a partial set for Case 4. These documents are interlinked and fully searchable at http://nuremberg.law.harvard.edu.

With this many documents (and many more to come), design of the search function for documents and transcripts is critical. A number of search options exist. Within any given trial, one can filter transcript search results by date (a drop-down menu lists all dates that trial was in session), author, defendant, or trial issue. For example, for Case One, the Medical Case, clicking on "Karl Gebhardt," one of the twenty-three defendants, returns sixty-nine results. Clicking on the title of any of the listed documents brings up an image of the paper document. (A magnification option is available.)

the Blue, Red, and Green sets, it remains the only known online guide to the Nuremberg records in English. The two later NARA finding aids are available only at NARA and at the Wisconsin Historical Society. 
In this example, clicking on the first title in the list brings up an image of a 1946 affidavit by Oswald Pohl about medical experiments on concentration camp inmates. The document has an original Nuremberg evidence code of NO-65. The information panel to the right of the image provides links to the author and to the defendants mentioned. Clicking on the evidence code number, NO-65, brings one to a list of all forms of this document: a photostat of the German original, a German transcript of it, an English translation of it, and its Staff Evidence Analysis. All of these images can be downloaded as PDF files.

An advanced search option is found at the bottom of the home page. The page gives a high-level overview of all 10,000 individual documents currently available; users can narrow a search by material type, date, trial, defendant, author (101 so far), language, source, or trial issue. It is perhaps this latter choice that researchers will find most useful: 80 issues are listed so far, ranging from "hostage-taking and reprisal actions" to "sterilization experiments." (Trial issues are taken from a controlled list, as are names for case files.)

The ability to search through this immense trove of records and quickly pull out all documents related to a specific issue, such as "Night and Fog Decree," is an example of the power of digitization. Having the trial record online opens up new research possibilities. The user can instantly access 86 documents relevant to this issue; a search of the best alternative site ( $\mathrm{Li}-$ brary of Congress Military Legal Resources) brings up nothing.

\section{A Look at Other Online Collections}

Only a few digital libraries have trial-related records - Cornell's Donovan Collection, Yale's Avalon Project, the Library of Congress, the University of North Dakota:

- Cornell's Donovan/Nuremberg Trials Collection offers nearly 2000 digitized documents online, selected from a larger collection of over 150 volumes of trial-related materials, as well as personal papers of Col. Donovan.

- The Avalon Project offers a complete online transcript of the International Military Tribunal at Nuremberg (the first, most famous trial) but without actual page images, evidence files, or links to cited documents. (The transcript is a copy of that found in the "Blue" series.) Many ancillary documents, as well as key documents from Trial 4, are also found on this site. There is no coverage of the other NMT trials. 
- The LoC site offers searchable PDF versions of the original Blue, Green and Red series of volumes issued by the US government at the conclusion of the trials.

- The University of North Dakota has digitized 1100 pages (of their 240,000 page collection) related to the German invasion and occupation of Norway, in a project funded by the Museum of the Norwegian Resistance in Oslo.

The National Archives and Records Administration owns the complete record of the trials in both paper and microfilm. A few items are available online, but viewing the actual record requires visiting Washington or purchasing costly microfilm. (To purchase the 48-roll microfilm record of Trial 7 , as an example, at $\$ 125 /$ roll, would cost $\$ 6000$.)

Supplementing the official record, of course, are the many collections of personal papers of trial participants; 27 of these (from 24 men $^{25}$-judges, prosecutors, an economic analyst, and a psychiatrist) are listed in Appendix B. Similar collections are likely to be found in German archives. Ten of these collections are partially digitized, and offer a fascinating selection of private notes, newspaper clippings, trial documents, photographs, and ephemera.

Of these, the most fully accessible is the collection at Harvard of Assistant Counsel Drexel Sprecher's papers. Each of the more than 22,000 pages has been digitized, with a direct link embedded into the container list of the finding aid. Other collections, such as Thomas Dodd's papers at the University of Connecticut, with over fifteen hundred digitized items, are also worth perusing. (See Appendix B for a complete list of these collections.)

\section{Linked Repositories: Still in the Future}

In three of the cases mentioned above, a donor's personal papers are split between two repositories. Not one of these six websites informs the user of this fact. Even the Robert Houghton Jackson Center, a stand-alone nonprofit and archive devoted to the life and work of the former Supreme

25 At least six women were members of the US prosecution team. See Diane Marie Amann, "Portraits of Women at Nuremberg" (2010), available at: http://digitalco mmons.law.uga.edu/fac_artchop/1004, for details. One woman also served on the French prosecution team at the IMT. See also http://www.intlawgrrls.com/2007/0 6/women-at-nuremberg-prosecutors.html. 
Court justice, does not mention that some of Jackson's papers are held at the Library of Congress. None of the repositories refers the reader to related collections held elsewhere. (Each trial had multiple judges and prosecutors, so links to the relevant archives would be of great help to those researching any given trial.) As it stands now, only through use of a search engine can one get a complete picture of archival holdings related to Nuremberg. (Moreover, it is entirely possible that other collections of relevant personal papers exist in the United States, collections with no online presence at all.)

All of this leads one to wonder: wouldn't it be useful for repositories to become more aware of outside resources that are related to their own holdings? Providing linkage to related collections would be a great boon to future researchers, would save everyone a lot of time, would cost nothing, and would reflect well on each participating archive. Isn't it about time we got out of our silos and started cooperating?

\section{Is the Future of Research Online?}

The Nuremberg Trial Project website was launched in 2003. Since that time, the site has steadily attracted several hundred visitors per day. Several thousand websites (in over twenty languages) have linked to the Harvard site. According to Google Scholar, over a hundred scholarly articles and hundreds of books have cited the project website since its launch. As more material is uploaded, the number of visitors will continue to grow.

It will be a few more years before the entire record of the trials is online. It's possible that this milestone might be achieved in time for the 75 th anniversary of the beginning of the Trials. The next phase of the projectstill on the drawing board today-could include linkage out to related collections around the world, as well as to entities such as DBpedia, "a crowdsourced community effort to extract structured information from Wikipedia and make this information available on the Web." ${ }^{26}$ In addition, API delivery of document metadata (i.e., delivery to machines by means of an "application programming interface") is anticipated. With these features and others still under discussion (or awaiting discovery), it appears certain that the Nuremberg Trials Project will become the leading resource in this field ... and it will make life much easier for those wishing to examine this fascinating episode of twentieth-century history.

26 Learn about DBpedia. 


\section{APPENDIX A}

U.S. "recipients" of trial records in 1949, with current status

(paper unless otherwise noted*)

National Archives and Records Administration: complete paper and microfilm record

Harvard Law School: one million pages of trial records (all 13 trials, partly digitized)

University of Washington School of Law: 1,236 bound volumes (all 13 trials)

Center for Research Libraries, Chicago: extensive holdings (all 13 trials)

University of North Dakota: 240,000 pages total; 1100 documents related to occupation of Norway digitized (https://library.und.edu/digital/nuremberg-transcript $\mathrm{s} /$ )

University of Michigan: 413 volumes covering Trials 1-12 (and possibly IMT)

University of Cincinnati: fifty volumes, IMT transcript plus index

Hoover Institution/Stanford University: 75 linear feet, IMT only

Columbia University: extensive holdings (all 13 trials)

University of Georgia Law School: Several indictments, opening/closing statements, and judgments, plus dissenting opinions, motions, and transcripts of a few videos. Trial 11, the "Ministries Trial," is exceptionally well documented.

http://digitalcommons.law.uga.edu/nuremberg/

University of Southern California: 300 boxes of transcripts of all 13 trials (this repository was not mentioned in any contemporaneous source as a recipient)

National Library of Medicine, NIH (formerly Army Medical Library): 18 linear feet of transcript and evidence from Medical Trial

Correspondence (end of 2017) with the following "named recipients" revealed no significant collections of trial documents. ${ }^{* *}$ indicates collection of personal papers-see Appendix B.

$\begin{array}{lll}\text { University California-Berkeley } & \text { University of Chicago } & \text { Duke } \\ \text { Princeton } & \text { Northwestern } & \text { West Point } \\ \text { University of Wisconsin } & \text { University of Arkansas } & \text { Georgetown } \\ \text { University of Nebraska } & \text { NY Public Library } & \text { Cornell*** } \\ \text { University of Texas** } & & \end{array}$

"Most academic libraries own the official published volumes of trial records, referred to as the "Blue," "Red," and "Green" series. The above list refers to the actual trial records only (bound or unbound), and not to these published multivolume series. 


\section{APPENDIX B}

Principal U.S. Collections of Personal Papers related to the Trials (alphabetical by donor surname)

Nürnberg Krupp Trial Papers of $\mathrm{Hu}$ C. Anderson, Vanderbilt University, Nashville, TN: https://krupp.library.vanderbilt.edu

Walter Beals Papers at University of Washington, Seattle, WA: http://archiveswest.o rbiscascade.org/ark:/80444/xv47470

Francis Biddle Papers at Georgetown University, Washington, DC: https://repositor y.library.georgetown.edu/handle/10822/559026

and the Francis Biddle Collection at University of Syracuse, Syracuse NY: https://li brary.syr.edu/digital/guides/b/biddle_f.htm

Guide to Trial Notebooks from Nuremberg Justice Case at University of Texas, Austin TX: Judge Mallory Blair collection, includes 70 volumes of records from this trial: https:/legacy.lib.utexas.edu/taro/utlaw/00022/law-00022.html

Edward F. Carter Papers, Nebraska Historical Society, Lincoln, NE: https://history. nebraska.gov/collections/edward-francis-carter-1897-1981-rg4231am

William Christianson Papers at U.S. Holocaust Memorial Museum, Washington DC: https://collections.ushmm.org/search/catalog/irn502047

Richard Dillard Dixon Papers, East Carolina University, Greenville, NC: https://dig ital.lib.ecu.edu/special/ead/findingaids/0601/

and University of N. Carolina, Chapel Hill, NC: http://finding-aids.lib.unc.edu/035 $67 /$

Thomas Dodd Papers at University of Connecticut, Storrs, CT: http://archives.lib.u conn.edu/islandora/object/20002\%3A20

Donovan Nuremberg Trials Collection at Cornell University, Ithaca, NY: http://la wcollections.library.cornell.edu/nuremberg

Benjamin Ferencz Papers at U.S. Holocaust Memorial Museum, Washington DC: https://collections.ushmm.org/search/catalog/irn508277

Paul H Gantt Nuremberg Trial Papers at Towson University, Towson, MD: http://li brary.towson.edu/digital/collection/gantt

Winfield B. Hale Papers at University of Tennessee, Knoxville, TN: http://dlc.lib.ut k.edu/spc/view?docId=ead/0012_002411_000000_0000/0012_002411_000000_00 00.xml

Hebert Nuremberg Collection at Louisiana State University, Baton Rouge, LA: https://digitalcommons.law.lsu.edu/nuremberg/

Robert H. Jackson Papers at Library of Congress, Washington, DC: https://www.lo c.gov/item/mm83061408/

and the Robert H. Jackson Center Archive, Jamestown, NY: https://www.roberthja ckson.org/archive/ 
Robert Kempner Papers at U.S. Holocaust Memorial Museum, Washington DC: https://collections.ushmm.org/search/catalog/irn502566

Douglas McGlashan Kelley Papers at University of California, Santa Cruz, CA: http:/www.oac.cdlib.org/findaid/ark:/13030/kt5d5nc7tj/entire_text/

Michael A. Musmanno Papers at Duquesne University, Pittsburgh, PA: http:/guide s.library.duq.edu/musmanno-nuremberg

John Johnston Parker Papers at University of North Carolina, Chapel Hill, NC: http://finding-aids.lib.unc.edu/03566/

Henry Schneider Papers at Columbia University, NY, NY: https://findingaids.librar y.columbia.edu/ead/nnc-rb/ldpd_10392013/

Harold Sebring Papers at Stetson University, DeLand, FL: http://digital.archives.ste tson.edu/cdm/search/collection/LawSebring/order/descri

Drexel Sprecher Collection at JFK Presidential Library, Boston, MA: https://www.jf klibrary.org/Asset-Viewer/Archives/DASPP.aspx

and the Sprecher Collection at Harvard Law School Library, Cambridge, MA: http://oasis.lib.harvard.edu/oasis/deliver/ law00216

Telford Taylor Papers at Columbia University, New York, NY: http://www.columb ia.edu/cu/lweb/archival/collections/ldpd_10199444/

Charles Wennerstrum Papers, Drake University Law School, Des Moines, IA: http:/ /www.drake.edu/law/library/collections/special-collections/

John C. Young Papers at the Truman Library, Independence, MO (in which Case 12, the High Command Trial, is particularly well documented): https:/www.tru manlibrary.org/hstpaper/youngjc.htm

Harry S. Truman Presidential Library and Museum hosts the "War Crimes Trials at Nuremberg" Collection. This wide-ranging collection features 335 documents totaling 4146 pages, plus photographs, oral history transcripts, and more: https:/ /www.trumanlibrary.org/whistlestop/study_collections/nuremberg/index.php?ac tion $=\mathrm{bg}$ 


\title{
United States Military Law of War Doctrine: \\ Making the International Criminal Court Irrelevant to the \\ Ground Combat Forces of the United States in the Early \\ Twenty-First Century
}

\author{
Rex A. Childers
}

In response to questions regarding the policies of the United States government and its relation to the International Criminal Court (ICC), and specifically the topic "Accountability in the Current War on Terrorism," a discussion will be offered to magnify issues that are not readily available to the general public and are often overlooked by those within the debate itself. A differentiation between external and internal factors affecting military policies will be made, with a focus on the effectiveness of the internal policies. In pursuit of this goal, a synopsis of the present political and social climate will be shared, followed by a hypothetical proposal to allow the reader to engage the imagination to focus on the main arguments offered. Once the reader has been "strategically" deployed into this "hypothetical alternative world," it should be possible to set aside any pre-conceived ideas regarding the "Global War on Terror," the United States Government, its enemies, and its allies. The goal is to enable the reader to "step into the boots" of a ground soldier in combat and realize the environment in which a member of the United States armed forces operates while deployed to a conflict. The requirements placed upon the lawful combatant and their impact on the ability of the United States military to prosecute a war within Law of Warfare (LOW) guidelines, as well as the possible consequences for criminal deviance facing a non-compliant soldier, will be considered. Finally, the potential institutional and national implications of criminal behavior and punishment inside the military will be reviewed.

The arena of discourse on political, legal, and moral challenges facing the United States and its allies in the current conflict does not suffer from a lack of commentators working to achieve success in influencing the actions of the U.S. government. This is as it should be in an open society, and it is even more important during a period of war. In the commentary surrounding the current "War on Terror," one of the common complaints about the Bush administration concerns its unwillingness to submit to "international review" of its conduct. Since approximately 3,000 people were 
killed in the attacks on the World Trade Center in New York on September 11, 2001, the Bush administration has aggressively interpreted its powers, both domestically and internationally. The fact that in 2002 the United States announced the withdrawal of the Clinton administration's signature of the Rome Statute in 2000 opened the United States up to charges of arrogance and even hubris. In the imaginative logic of critics, the ICC would add a missing piece of international legal and moral authority that would act to regulate the behavior of the United States military. This is an example of an external factor, and the possibility that this structure could serve a broader purpose in dealing with the actions of the preeminent superpower (in both an economic and a military sense) carries deeper international implications.

In Johnathan Swift's classic Gulliver's Travels, the character of Gulliver represents the superpower in a new world. Having fallen from his ship and washed ashore only to be tied down by the Lilliputians while he sleeps, Gulliver is forced to agree to a treaty with the "monarch of all monarchs" in order to gain his physical freedom:

First, the Man-Mountain shall not depart from our dominions, without our licence under our great seal. Second, he shall not presume to come into our metropolis, without our express order; at which time, the inhabitants shall have two hours warning to keep within their doors. Third, the said Man-Mountain shall confine his walks to our principal high roads, and not offer to walk or lie down in a meadow or field of corn ... Sixth, he shall be our ally against our enemies in the island of Blefescu, and do his utmost to destroy their fleet, which is now preparing to invade us. ${ }^{1}$

The Lilliputian restrictions on Gulliver require some assistance from Gulliver himself. In order to be secured by the ropes (institutions) initially by the miniature inhabitants of Lilliput, Gulliver has to be rendered immobile and unaware for some significant period of time, which he effects by allowing himself to take a drunken nap on a foreign shore. Once he has been restricted, the ability of the Lilliputians to convince him to submit to their conditions is enhanced. His captors offer him a limited form of freedom, but they have only been able to restrain him after he incapacitated himself.

The goal of the ICC is similar: many of the earliest and most supportive states in this treaty made a rational decision to participate based on a pre-

1 Jonathan Swift, Gulliver's Travels (New York: The MacMillan Co., 1927), 35-36. 
ferred outcome (restriction of a superpower) at relatively minimal cost. Among the current participants in the ICC, it is not likely that states as diverse as Albania, Colombia, and Ghana voluntarily ceded significant sovereign capacities without considering how they could benefit from the institution as envisioned in this structure. The possibility that a state's political leadership could be held accountable for the offenses initially listed in the ICC-genocide, war crimes, and crimes against humanity-and potentially for the crime of aggression (yet to be defined by the ICC) offers a form of protection against deployable militaries, a form of anti-superpower invasion insurance.

In relation to the U.S. military, which is guided by a legal code of conduct and where members can and have been charged and convicted of crimes, the impact of an international or "extra-sovereign" structure like the ICC must be classified as an external force, secondary to the internal requirements. To the extent that such a structure would become normative and impact the application of law inside the military, the public discourse surrounding the issue is valuable; nevertheless, the assumption that the United States military operates in disregard of the applicable law of war guidelines it is bound to through treaty ratification or in adherence to the body of international law referred to as customary international law is based more on fiction than on fact.

The theory of customary international law and its applicability is significant to the issue of the International Criminal Court. In addition to the forms of law that have traditionally bound states in their actions toward each other (i.e., treaty law), customary international law has achieved status in defining international norms through another method beyond the explicit agreement by the state. Jack L. Goldsmith and Eric A. Posner describe the traditional understanding as follows:

Customary international law is typically defined as the general and consistent practices of states that they follow from a sense of legal obligation. This definition contains two elements: there must be a widespread and uniform practice of states, and states must engage in the practice out of a sense of legal obligation. ${ }^{2}$

While the ICC is a multilateral treaty form of international law, there is no assumption that its jurisdiction will be interpreted solely on the basis of treaty law. A substantial amount of influence on the normative practice in

2 Jack L. Goldsmith and Eric A. Posner, The Limits of International Law (Oxford: Oxford University Press, 2005), 23. 
international law, including international humanitarian law, where law of warfare is generally classified, comes from the progressive nature of opinio juris, the second element of Goldsmith and Posner's definition above, which poses a significant challenge to the ICC in the instance where a nation may be a signatory of one form of treaty law but not another. In such a case, which international standard is to be used?

The United States is a case in point. During the twentieth century the United States agreed to most international law of war guidelines, including the Geneva Conventions of 1949. However, the U.S. has never ratified a major international revision known as the Protocol Additional to the Geneva Conventions of 12 August 1949, and Relating to the Protection of Victims of International Armed Conflicts (Protocol I), 8 June 1977. The significance of this revision - and the decision by the Carter administration to act in variance against the dominant will of the international community—has been discussed in a recent article by Samuel Jones. The political process and the international environment of the 1970s led to a final treaty that blurred the important distinctions between civilian and combatant, vastly changing one of the major tenets of law of warfare, "the reciprocal nature of armed conflicts and the justification for IHL [International Humanitarian Law]": "The classical view that distinction between civilians and combatants should always be observed was subordinated to the apparent social or political desires of certain nations to protect insurgents." 3 So in the hypothetical case of the ICC investigating charges of an American violation involving the issue of status (civilian or combatant), which standard would be used, The Geneva Conventions of 1949, of which the United States is a signatory and compliant member, or the murky guidelines of Protocol I? Is it improbable that the international standard would be applied to the case using Protocol I under the justification of customary international law, even though the United States has consistently rejected that treaty?

The relevance of the ICC to the United States military is moot because the U.S. government is not a signatory; however, for the purposes of this paper, the reader is encouraged to "imagine" the United States as a complying member of the ICC, stipulating that the ICC's reach is also subject to the complementarity enforcement limitations of the statute. The ICC

3 Samuel V. Jones, "Has Conduct in Iraq Confirmed the Moral Inadequacy of International Humanitarian Law? Examining the Confluence between Contract Theory and the Scope of Civilian Immunity during Armed Conflict," Duke Journal of Comparative and International Law 16 (Spring 2006), 249. 
includes the concept of complementarity as one of the principles of the Rome Statute itself, as noted in both the Preamble and in Article 20, 3:

No person who has been tried by another court for conduct proscribed under article 6,7 , or 8 shall be tried with the court with respect to the same conduct unless the proceedings in the other court:

a) were for the purpose of shielding the person concerned from criminal responsibility for crimes within the jurisdiction of the court; or

b) otherwise were not conducted independently or impartially in accordance with the norms of due process recognized by international law and were conducted in a manner which, in the circumstances, was inconsistent with an intent to bring the person to justice. $^{4}$

According to Xavier Philippe "the principle of complementarity is based on a compromise between respect for the principle of state sovereignty and respect for the principle of universal jurisdiction." 5 This compromise places the state at the forefront of the process of enforcing the international laws surrounding war, subject to the possibility that the ICC may rule independently within the conditions listed above. The idea depends on numerous factors, including the development and sophistication of the national judicial system, and the willingness of the international community to accept the judgment of the sovereign legal system. Philippe continues:

If one person is accused of an international crime but insufficient evidence is gathered or the rules for a fair trial are not met, national judges may be reluctant or refuse to prosecute the accused. They would comply with their national judicial framework, but not necessarily with the international requirement. Would the ICC accept such a situation, or would it initiate proceedings on grounds of unwillingness or inability to prosecute war criminals? ${ }^{6}$

Although the national judicial processes involved in the United States military can be considered developed when viewed in the context of comparative national military systems, it is not beyond the realm of possibility that

4 Rome Statute of the International Criminal Court, revised January 2002, 22, www.iccc pi.int/lbrary/about/officialjournal/Rome_Statute_English.pdf.

5 Xavier Philippe, "The Principles of Universal Jurisdiction and Complementarity: How do the Two Principles Intermesh?" International Review of The Red Cross 88.862 (June 2006), 380.

6 Philippe, 391. 
the ICC and its member states would find its processes to be insufficient to meet international criteria. The subjective nature of the global political environment, as well as the potential focus of the ICC on the leadership of a state or its military, makes the complementarity principle problematic, but not entirely prohibitive to its applicability.

From this point on, the relevant question on the ICC's impact can be considered on the basis of the "in theater" effect on the decision-making and actions of the uniformed military service. In order to accelerate the orientation, some Operation Iraqi Freedom (OIF) history follows.

In November 2003, on a highway outside Kirkush, Iraq, a series of three explosions rocked a small convoy of Ohio Army National Guard Military Police Humvees. The improvised explosive devices had been buried under the road and were detonated by wire from a nearby location. These explosives were large, a characteristic of rigged heavy artillery shells. In response to the explosion, Sergeant Leon Schultz, manning an automatic weapon in the turret of one of the vehicles which had been spun around by the blast and was sitting motionless, observed a likely location for the source of the detonation: a small building standing alone by the road. The insurgency tended to follow a pattern, with a detonation from a point of observation, followed by a concentration of fire on immobile vehicles or soldiers lacking cover or attempting to rescue fellow soldiers. On this basis, Sergeant Schultz, after clearing his head from the effects of the blast, directed his fire at the building while his vehicle driver worked to get the Humvee started and moving out of the kill zone. Sergeant Schultz continued providing fire as the vehicles pulled out of the center of the ambush site, in compliance with his standing orders and the rules of engagement (ROE). ${ }^{7}$

In a second incident, in the early morning darkness of May 28, 2003, a squad-sized element of United States Army Military Police performing its assigned mission on a main supply route outside Camp Anaconda (formerly an Iraqi Airbase in Balad, Iraq) came under heavy automatic weapon fire from approximately 500 meters away, across the Tigris river. The fire was timed and sustained, tracking the 3 light-armored humvees along their normal route outside the perimeter of the massive base on the eastern tip of the Sunni triangle, north of Baghdad. The contact continued for approximately 20 minutes, but the squad continued its reconnaissance mission without casualties or damage. The soldiers, part of the Ohio Army National Guard from Toledo, Ohio, had entered Iraq in the second stage of the offensive portion of Operation Iraqi Freedom as part of the Fourth In-

7 Leon Schultz, personal interview, May 11, 2006, in Toledo, Ohio. 
fantry Division. The unit had settled into its mission after moving through Baghdad and had experienced fire before. The non-commissioned officer in charge of the mission, Staff Sergeant Paul Blake, continued to order all 3 of his vehicle gunners to refrain from firing their grenade machine guns toward the sources of the fire. The combat load of ammunition and the capability of this weapon in this situation, with targets well inside its effective range, could silence much of the fire with a blanket of high explosive grenades fired at a rate of three rounds per second. Staff Sergeant Blake, a 24-year veteran of the army with many international deployments behind him, made the judgment based on numerous factors: his experience, his awareness that the area being used by the enemy was a residential area containing families, and the rules of engagement (ROE) in force in the Iraq theater. ${ }^{8}$

The ROE Card is carried by all soldiers in theater, usually inside their helmet, and is the guide to use of force. Staff Sergeant Blake relied on the first rule of the Operation Iraqi Freedom ROE Card: (1a) "Positive Identification (PID) is required prior to engagement. PID is a reasonable certainty that the proposed target is a legitimate military target," and (1d) "Do not fire into civilian populated areas or buildings unless the enemy is using them for military purposes, or if necessary for your self-defense. Minimalize collateral damage." Facing the possibility that his squad might incur casualties from the fire while continuing their mission, Staff Sergeant Blake determined that the combination of factors (low visibility, mission completion, and ROE requirements) did not justify unleashing up to 500 rounds of high explosive grenades into a civilian area:

I knew from traveling through that area during daylight that families lived there. I felt that the fire did not pose great danger, even though it was heavy. It seemed to be probing and systematic, as if the varied firing positions were hoping to get us to stop and direct fire into the area. Also, there was the possibility that the enemy was attempting to draw us into firing into a civilian area, a tactic we had been warned about as it tended to get the local population angry at us and made a great story for press outlets opposed to the war. ${ }^{10}$

8 Paul F. Blake, personal interview, May 11, 2006, in Toledo, Ohio.

9 United States Military Operational Law Handbook, JA 422 (Charlottesville, VA: International and Operational Law Department, The Judge Advocate General's Legal Center and School, 2006), 120.

10 Blake interview. 
He was willing to hold his fire, potentially risking his own life and the lives of the 9 other soldiers he was accountable for. What makes this ROE Card so powerful that an entire squad of soldiers would resist their capability to deliver deadly ordnance on a combatant position?

There are 3 dominant internal mechanisms that prepare a small unit leader to make this type of decision: doctrine, training, and the existing Uniform Code of Military Justice (UCMJ). In the case of doctrine influencing mission behavior, the rules of engagement originate from doctrinal practice and, as noted in the 2006 edition of the U.S. military's Law of War Handbook, "U.S. Law of War obligations are national obligations, binding upon every soldier, sailor, airman, or Marine." ${ }^{11}$ The law of war originating from "international law that regulates the conduct of armed hostilities" is communicated down through the chain of command and support through intensive review and the production of briefings and training guides by the Judge Advocate General Corps (JAG). In addition, the JAG corps trains and tasks its members, military lawyers, to be assigned directly to advise battlefield commanders in the support of training standards for law of war guidelines, as well as review of the commander's written orders for operations. JAG lawyers are an integral part of drafting written operation orders for units and are tasked with insuring that "1) law of war issues have been addressed, and 2) legally and practically sufficient rules of engagement (ROE) have been defined." 12 In both operational and training modes, the role of doctrine is a critical primary internal force affecting the actions of United States military personnel.

The second important internal force that impacts the United States combat soldier is training. Few other organizations can match the depth and regimentation of the training module for all levels of its members. Through a combination of training and field manuals, the doctrinal guidelines are merged into written policies that are communicated to all appropriate levels of the organization. The integration of national and international law into practical guidelines that provide for the accomplishment of the mission of the troops is critical to prosecuting the "War on Terror" within the parameters of the laws of the United States and all applicable international treaties and obligations. Using these manuals, soldiers in leadership roles are responsible for conducting realistic and relevant training for their subordinates. As a consistent thread throughout combat training, the individual soldiers remain responsible for their own actions in bat-

11 United States Military Operational Law Handbook (2006), 12.

12 Ibid., 542. 
tle, and soldiers in leadership roles are trained to standard when they accept responsibility for their own behavior as well as that of their subordinates. Each soldier under the command of a leader, as in the case of SSG Blake, is trained to understand the importance of distinguishing between a "lawful" and an "unlawful" order. A lawful order is one that "requires the performance of a military duty or act ... it is disobeyed at the peril of the subordinate. This inference does not apply to a patently illegal order, such as one that directs the commission of a crime."13

Another distinction that is part of both initial and ongoing training of troops has to do with the term "civilian," which, often used to cover a wide range of individuals in theater, requires further clarification and distinction. In the conduct of a war involving an insurgency that remains nonuniformed in order to blend into the "civilian" population, the correct terms to classify individuals would be "non-combatant" and "combatant," as provided for in customary law of war language. While a non-combatant may be assumed to be a civilian, this is not universally true. An individual who lacks the characteristics that usually identify a combatant (uniform of a state, open display of weapons, ID card that specifies compliance and status under the Geneva Convention, etc.) can be classified as a combatant if they are engaged in warfare. By using known areas of civilian population to engage U.S. forces, such individuals endanger the lives of non-combatant civilians. In the incident previously reviewed that occurred in Balad, Iraq, the combination of individual training, discipline, and leadership within the military worked to avoid unnecessary death and destruction in an area populated by civilians. These internal controls on use of force worked, even though the actions of the enemy made their locations a legitimate military target for the purpose of self-defense (force protection).

The final internal force to be discussed regulating the behavior of U.S. military personnel is the Uniform Code of Military Justice (UCMJ) as expressed in the Manual for Courts-Martial, United States. This is the legal structure that provides the military with its ability to prosecute its members for crimes committed while enlisted or commissioned in the service. In principle, the jurisdiction of the UCMJ includes both the U.S. Constitution and international law, including law of war. ${ }^{14}$ As an example, according to Article 118, the crime of murder can be punished by imprisonment for a period to be determined by a court, a mandatory life or a mandatory

13 Manual for Courts-Martial United States (Washington, DC: United States Government Printing Office, 2000), 4:19.

14 Ibid., 1:1. 
death sentence, depending upon circumstances, and according to Article 120 , the crime of rape (including specifications regarding carnal knowledge of minors) also carries a potential death sentence. ${ }^{15}$ These are just two examples of the existing legal ramifications facing American ground forces with respect to their conduct both in peacetime and in war. For the soldier deployed to perform a mission in a hostile theater, the specter of criminal punishment for behavior is not a primary daily concern, but it is important to note that each soldier is aware of the basic requirements of law of war guidelines as standing regulation that cannot be overridden by operational orders.

With a military that depends on an all-volunteer pool of recruits, the United States has an important interest in maintaining a system of justice internally that addresses any criminal deviance of its members. As in any large organization or society, there are individuals who do not feel compelled to comply with the rules of the organization, and unless they can be identified by their leadership as substandard and either required to receive additional training or, in the case of a more severe pathology of disobedience, separated from service by discharge, they can pose a threat to the mission and the military. Although such individuals may represent a very small percentage of the personnel, their deviant acts reflect negatively on the work of the military. For this reason, the focus of the military justice system during the "Global War on Terror" must remain clear in its application of criminal charges, and those personnel who are found to be guilty of crimes-whether or not they rise to the level of crimes that would be in the jurisdiction of an International Criminal Court-must receive appropriate sentencing. It is not an adequate defense for a member of the military simply to argue that "they were just following orders" (a defense that Nuremberg negated) when the behavior is clearly outside the training and doctrine of their profession.

In the practice of military operations, the United States military must depend on its internal mechanisms for accountability. Doctrine, training, and the existing Uniform Code of Military Justice form the basis for complying with domestic and international law. Until the U.S. military begins to deploy combat companies full of trained lawyers to "prosecute" the war, the world will have to hope that 26-year-old platoon sergeants, 23-year-old lieutenants, and 21-year-old privates manning crew-served weapons are sufficient to uphold the internal forms of accountability and dispense justice. To the lawful combatant of the United States military, national obligations

15 Ibid., 4:62-64, 66-67. 
are assumed and met entirely through these internal forms of normative practice. Operating in a daily environment of extraordinary stress and occasional fear, they must balance their own basic needs for survival, as well as their obligations to their comrades in protecting their safety, against the real possibility that their own actions may result in a form of disciplinary action, judicial punishment, or even imprisonment. In addition, the effects of their behavior in the political and media arenas on the mission are clearly under consideration. It cannot be disputed that illegal behavior by a small number of members of the United States armed forces, as in the case of the convicted guards at Abu Ghraib prison, harms the international image of the U.S. military. This is especially likely in a media environment driven by a dominant narrative ("the war is unpopular or should be") and commercial motivation to sell the story using the most graphic descriptions of behavior. The Abu Ghraib story served to confirm the worst prejudices against the war and the U.S. military. A systematic or doctrinal mistreatment of prisoners was alleged, but numerous critical facts were omitted from the public discourse, including that the story had not been broken by an investigative reporter, but through the efforts of an enlisted soldier who became aware of the behavior and reported it to his superiors. The internal system of normative behavior brought the crimes to the attention of the military justice system. The release of information to the public was made possible by the system, not by an external method of enforcement.

As Nuremberg ushered in a new era of international legal oversight in the conduct of war, it is worth remembering that Nuremberg and other post-World War II courts and tribunals conducted to address the atrocities of the Axis powers became possible only through the complete and unconditional surrender of the enemy. The incongruence of this reality with the idea of the progressive improvement in international relations, as in the case of the debate over a permanent body of jurisdiction to deal with crimes of international conflict, is striking. A structure to ameliorate the impact of brutality in the case of wars between states is a worthy and idealistic goal, and to the extent that the institution promoted in the ICC adds to the transmission of normative values through a communicative process that allows for states to make rational choices in their conduct of foreign policy (including war), the benefits may outweigh the risks to an individual nation in becoming a participating member of the ICC. However, it is not true that the stroke of a pen can transform the basic security interests of a state from a sovereign responsibility into an international form based upon collective cooperation. Each state must judge its own interests and those of its citizens in the historical context of the international communi- 
ty as it has existed in history. For the United States, the international record on delivering desired results has been marginal at best, and particularly in the area of national security. Proponents of the ICC as the structure that would provide the missing international enforcement mechanism to limit the behavior of states in the area of warfare are disregarding a fundamental conceptual element: the responsibility of sovereignty. For the United States military in the twenty-first century, the existence of the ICC will remain an external influence, but largely irrelevant to its mission of providing national security for its citizens. 


\section{Subject Index}

academia 42, 100

accountability 94, 159, 161, 173, 175,

176, 181, 189, 191, 205, 268

Allied Control Council 16, 55-57, 69, 76

anti-fascism 49

Auschwitz Trial 47

Austria 71-73, 77, 96

Belgium 79, 162

Berlin Document Center 242

Bosnia 185, 186

Briand-Kellogg Pact 14

Cambodia 190, 227, 238

Celebici Case 217

ChGK, (Soviet Commission for the Investigation of Nazi War Crimes) 25-27, 35-39

civilians, crimes against $6,86,196$, 199, 207-209, 213, 217, 262, 267

'comfort stations' 205

complementarity 18, 53, 148, 161, 172-177, 182, 189-191, 262-264

concentration camps 62-64, 66, 76, $81,168,184,202,249,252$

constitution(s) 45, 166, 235

Convention on the Elimination of All Forms of Discrimination Against Women (CEDAW) 210

Convention on the Prevention and Punishment of Genocide 212

Czechoslovakia 71, 162, 171, 243, 246

Dachau 66, 68, 164, 169

Darfur 149, 232, 233

detention 170, 218, 231

ethics 143

'ethnic cleansing' 51, 146, 211, 216

fascism 24, 32, 34, 39, 49, 104, 106, 115
Fedorov (Antifascist Youth) 34

formalism 106-108, 113, 143

Furundzija Judgment 222

genocide $6,18,51,53,78,160,167$, 184, 185, 194-196, 200, 203, 211-216, 219-225, 228-231, 233, 236-238, 261

Harvard Law School 18, 19, 105, 106, 111, 239, 246, 249

historiography 23, 48, 91

ICTR for Rwanda 190, 191, 195, 216, 219, 224, 225, 228, 230, 231, 233-235, 237

idealism 5, 10, 15

immunity 7

Inter-Allied Joint Declaration on the Punishment for War Crimes 84

International Criminal Court 7, 10, $17,18,41,135,173,195,225,259$, 261, 268

International Humanitarian Law 262

International Military Tribunal for the Far East (IMTFE) 83-85, 87-92, 94-101, 137, 200, 204

Japan 17, 83, 88, 96, 98, 162, 204, 206

JCS Directive 106755

Jews, persecution of $46,62,63,66-68$, 159, 167-169

Jurisdiction, universal 149

Jurisprudence, international 103, 117

Katyn Case 37, 38

Kellogg-Briand Pact 14

Kosovo 146, 185

law $6,9,10,15-17,19,24,29,35,41$, $42,45,47,50-60,63,65-70,72,74$, 76-78, 80, 87-90, 92, 94-96, 99, $101,103-113,115,117-129,131$, 139, 140, 142-145, 148-150, 153, 
$155,156,161,164,166,168,172$, 175-177, 181, 187-190, 194-198, 200, 202, 203, 207, 211, 213, 216, 220, 225, 227, 230, 234-239, 250, $251,261,262,266-268$

lawyers $15,29,43,44,54,88,103,111$, 113, 136, 182, 234, 243, 266, 268

liability 67, 69, 70, 118, 202, 203

Lieber Code 198, 199

majority rule 116

morality 104, 105, 108, 109, 117, 121, $123,124,128,198$

myths $16,23,36,110$

national socialism 76

Nazi Banning Act 71-73, 75, 81

'Night and Fog Decree' 252

'Night of Broken Glass' 60, 81

non-retroactivity, principle of 44,45 , 52

Nuremberg Trials Project at Harvard 239, 251, 254

Pearl Harbor, Japanese attack on 96, 98

pogroms 60

Poland 6, 162, 171, 178, 243, 246

positivism 105, 106, 108, 109, 115, 116, 120, 121, 123

Potsdam Declaration 85

prisoners $5,6,10,62,74,147,160$, 169, 199, 207, 269

psychiatry and law 108, 110, 112, 114, 119

rape $18,85,167,193-209,213-238$, 268

Red Cross 29, 77

Rome Statute 53, 139, 148-153, 173, 225, 228-231, 237, 238, 260, 263

rule of law 10, 16, 45, 54, 80, 103, 139, $140,143,148,156$

rules of engagement 264-266

Rwanda 18, 137, 182, 195, 215, 216, 219, 233 selective justice $17,18,138,144,147$, $148,151,152,155$

selective prosecution 138, 139, 143

sexual violence $18,160,167,168,181$, 190, 193-206, 208-211, 213, 215-224, 226-228, 230, 232-238

socialism 76

sovereignty $54,137,146-149,167$, 263, 270

Soviet Commission for the Investigation of Nazi War Crimes 25

Stalinism 24

'Tanaka Memorial' 97

the Balkans 51

the Cold War 9, 24, 39, 51, 94, 100, $120,170,171,240$

The Hague 52, 72, 200, 210

the media 13, 42, 48, 91, 92, 95, 100, 250, 269

Tokyo Trial 17, 18, 83, 90, 91, 95, 98-100, 204

torture $10,74,80,167,195,196,201$, 203, 209, 211, 217-220, 222, 231, 236, 237

totalitarianism 104-106, 124, 131

U.S. Constitution 267

UN Charter 151

UN Security Council 41, 51, 148

UN War Crimes Commission 59

USSR 7-9, 23, 26-33, 35-37, 85, 98, 99, 162, 165, 246

utilitarian philosophy 121

vengeance 87,159

'Wochenschau' 42

World War II 5, 8, 14, 23, 39, 50, 55, 81, 84, 90, 101, 103-106, 115, 117, $118,121,122,124,127,137,200$, 269

Yalta Conference 55

Yugoslavia 18, 41, 51, 146, 161, 162, 182, 186, 187, 191, 195, 215-217, 233 


\section{Index of Persons}

Ackerman, Bruce A. 105, 107

Adler, Mortimer 114

Akayesu, Jean-Paul 219-225, 228, 231, 235

Aleksandrov, Georgii Fedorovich 32, 33,35

Andreeva, Fedorovna 30

Aristotle 142

Astor, Lady Nancy 31

Bakh, Aleksei Nikolaevich 29

Bartlett, Vernon 31

Basu, K.K. 87

Baur, Fritz 47

Beale, Joseph Henry 111

Bernard, Henri 97

Blake, Staff Sergeant Paul 265, 267

Bochkov, V.M. 33

Bogoiavlenskii, Piotr 37

Bogomolets, Aleksandr Alksadrovich 29

Born, Captain Lester 241, 242

Borodin, M. 34

Brown, Brendan F. 88-90, 94, 106, 125, 127-130

Brumlik, Micha 48

Burdenko, Nikolai Nilovich 29, 36

Carter, Jimmy 262

Churchill, Winston 5, 10, 159

Coogan, Major William H. 243

Dekanozov, V.G. 33

Derzhavin, N. 34

Epshtein, S. 34

Ferencz, Ben 53

Fischer, Joschka 53

Frank, Jerome 105, 106, 108, 109

Friedlander, Henry 57
Fuller, Lon 105, 106, 109, 115-118, 120, 121, 123, 131

Gabriadze, Rezo 23

Geiger, Hansjörg 52

Gienow-Hecht, Jessica C.E. 94

Gilligan, Carol 142

Gorbachev, Mikhail 50

Grewe, Wilhelm G. 41

Grizodubova, Valentina S. 34, 35

Gundorov, A. 34

Harris, Whitney R. 53, 249

Hart, H.L.A. 120-123, 131

Hirohito, Emperor 96

Hitler, Adolf 6-8, 17, 35, 56, 59, 63, $71,74,83,96,117$

Holmes, Oliver Wendell, Jr. 107-109, $112,117,125$

Hutu 137, 219, 220, 224

Iarushevich, Boris Dorofeevich 35

Ireland, Gordon 95

Jackson, Robert H. 5-10, 14, 15, 46, $53,54,89,119,253,254$

Jodl, Alfred 44

Johnson, Hewlett 30

Johnstone, Samuel V. 146

Kalinin, Mikhail Ivanovich 27

Kant, Immanuel 142

Kapitsa, Piotr Leonidovich 29-32, 34

Kaul, Hans-Peter 41, 53

Keenan, Joseph B. 88-90, 94

Khrushchev, Nikita S. 33

Komarov, V.L. 33

Kress, Claus 52

Krivtsov, Aleksei Nikolaevich 29

Kruif, Paul de 30

Kuroda, Lt. General Shigenori 164

Laurence, Geoffrey 87 
Lemkin, Raphael 211, 212

Lozovskii, Solomon Abramovich 34, 35

Lucey, Francis E. 117

Lysenko, Trofim Denisovich 36

MacArthur, General Douglas 95, 204

Maga, Tim 91

Maisky, Ivan Mikhailovich 30

Marinin, M. 28

Marrus, Michael 91

Martin, Terry 239

Mignone, Frederick 90

Milosevic, Slobodan 186

Molotov, Viacheslav Mikahilovich 25, $31,33,34,38$

Napoleon Bonaparte 14

Nemchinov, V. 33

Nickelson, Harold 5

Niebergall, Fred 243, 245, 247

Nikolai, Metropolitan 29, 35, 36

Northcroft, Erima H. 89, 90

Novikov-Priboi, Aleksei Silych 30

Overy, Richard 91

Pal, Radhabinod 97, 98

Penna, Lucas De 197

Philippe, Xavier 263

Piaget, Jean 110

Piccigallo, Philip 91

Ponomarenko, P.K. 33

Potemkin, V.P. 33

Priestley, John B. 30

Primus, Richard 104, 128

Radbruch, Gustav 45, 51, 67

Reemtsma, Jan Philipp 44

Robinson, Darryl 181, 247

Roosevelt, Franklin D. 6, 33, 159, 160, 163, 172

Rowney, Don K. 13, 19

Schlink, Bernhard 51
Schroeder, Gerhard 53

Schwelb, Egon 162

Sergeev-Tsenskii, Sergei Nikolaevich 30

Serov, I.A. 33

Shvernik, Nikolai Mikhailovich 35

Simon, John 33

Smith, Bradley F. 91

Stalin, Joseph 5, 24, 25, 27, 28, 30-32, $35,36,38,39$

Stalingrad, Battle of 23, 64

Stimson, Henry L. 6, 14, 16

Sutton, Daniel 88

Taft, Robert 9

Tarasova, Alla Konstantinovna 30

Tarle, Evgenii Viktorovich 36

Taylor, Telford 91, 245-249

Tolstoi, Aleksei Nikolaevich 25, 33, 36

Trainin, Ilia Pavlovich 36

Truman, Harry S. 6, 7, 14, 89, 170

Tusa, John 91

Tutsi 137, 215, 219, 220, 224

Umanskii, Konstantin Aleksandrovich 33, 35

Varga, E.S. 33

Vedeneev, Boris Evgenievich 36

Vyshinskii, Andrei Ianuarievich 25, 38

Webb, Sir William Flood 91

Weber, Max 140, 141

Wechsler, Herbert 105, 106, 124-127, 129-131

Wiecek, William 124

Wittman, Rebecca 48

Woetzel, Robert K. 91

Wright, Quincy 182, 183, 188, 239

Yamashita, General Tomoyuki 206

Zhdanov, Andrei Andreevich 28, 35, 38 